\title{
Instrumentalizando a gestão dos recursos hídricos através das geotecnologias: \\ Estudo para a bacia do Paraíba do Sul
}

\author{
Marcos André Sobral Escada
}

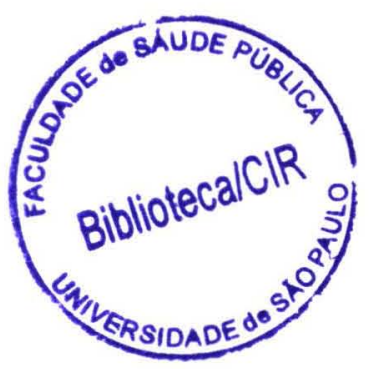

Tese apresentada ao Programa de PósGraduação em Saúde Pública da Faculdade de Saúde Pública da Universidade de São Paulo para obtenção do Grau de Doutor.

Área de Concentração: Saúde Ambiental Orientador: Prof. Dr. Roque Passos Piveli

\section{São Paulo}




\section{5 doc}

Autorizo, exclusivamente para fins acadêmicos e científicos, a reprodução total desta tese, por processos fotocopiadores.

Assinatura:

Data: 


\section{AGRADECIMENTOS}

Os meus sinceros agradecimentos ao Prof. Dr. ROQUE PASSOS PIVELI por ter encampado a idéia deste trabalho e por todo apoio dado nos momentos mais necessários.

À minha irmã Maria Isabel Sobral Escada por toda ajuda dada, em especial no auxílio do uso das geotecnologias.

À Cidinha, Marcia e demais funcionários da Faculdade de Saúde Pública que de uma forma ou de outra apoiaram o desenvolvimento desta tese.

Ao Prof. Dr.Antônio Miguel Vieira Monteiro por ter praticamente co-orientado esta tese.

À minha mãe Anna Maria Sobral Escada pela auxílio na revisão de português.

Aos meus filhos Carolina, André e Daniel e a minha esposa Célia, por compreenderem a minha dedicação à esta tese.

Ao meu pai Antônio Celso Escada, mestre em saúde pública, já há longa data, por esta mesma instituição, e que sempre me indicou a Faculdade de Saúde Pública como centro de excelência nesta área. 


\section{RESUMO}

ESCADA MAS. Instrumentalizando a gestão dos recursos hídricos através das geotecnologias: Estudo para a bacia do Paraíba do Sul. São Paulo; 2005 [Tese de Doutorado - Faculdade de Saúde Pública da USP].

A adoção no Brasil da bacia hidrográfica como unidade de gerenciamento dos recursos hídricos é bem recente - Lei Federal n ${ }^{\circ}$ 9.433, de 08/01/97. O estado de São Paulo, via de regra precursor nas iniciativas, não dispõe ainda de todos os instrumentos necessários para um adequado gerenciamento deste recurso cuja escassez, não só associada a quantidade, mas cada vez mais a qualidade, coloca em risco a qualidade de vida da atual e das futuras gerações. A qualidade das águas é determinada pelas impurezas presentes, introduzidas por fontes de poluição, entre as quais se destacam os efluentes domésticos, os efluentes industriais, o deflúvio superficial urbano e agrícola, resíduos de atividades de mineração etc., estando, portanto, associada ao uso e ocupação/cobertura do solo. As ferramentas atuais disponíveis não viabilizam uma adequada avaliação das cargas poluidoras de origem difusa. As Geotecnologias, Sensoriamento Remoto, Sistemas de Informação Geográfica, Bancos de Dados Geográficos, Sistema de Posicionamento Global, tecnologias da Internet e os ambientes para simulação apresentam-se como ferramentas apropriadas e mais sofisticadas para a avaliação de questões voltadas para a preservação e recuperação da qualidade das águas superficiais de bacias hidrográficas. Buscou-se então o desenvolvimento e avaliação de metodologias de trabalho em ambiente de suporte à decisão mais moderno através da revisão das ferramentas de Geotecnologias atuais disponíveis para a proteção da qualidade ambiental demonstrando sua aplicabilidade através da sua utilização através de subbacias na bacia do Paraíba do Sul. A partir dos dados disponíveis nesta bacia, foi possível determinar a carga de origem difusa adicionada referente aos parâmetros DQO e Sólidos Suspensos num trecho do rio principal, identificada como a parcela associada a eventos pluviométricos. Quantificou-se as vazões associadas aos usos e ocupação/cobertura do solo e a carga poluidora de origem difusa resultante, não sendo possível no entanto identificar a parcela da Concentração Média de Eventos de 
Chuva - CME para cada uso e ocupação/cobertura do solo. Obteve-se um produto que apresenta não apenas melhoria visual, mas uma metodologia que agrega valores por estar fundamentada em: banco de dados facilmente atualizável, dados de entrada obtidos de técnicas de medição não invasivas como é o caso do Sensoriamento Remoto, na integração de dados espaciais através de funções disponíveis num ambiente de Sistema de Informações Geográficas - SIG, entre outros.

Descritores: bacia hidrográfica, fontes não pontuais de poluição, Sistema de Informação Geografia, qualidade da água, uso do solo. 


\begin{abstract}
Escada MAS. Instrumenting hydrological resources management through geotechnologies: The studie case of Paraíba do Sul Basin. São Paulo (BR); 2005. [PhD Thesis-Faculdade de Saúde Pública da Universidade de São Paulo Brazil].
\end{abstract}

In Brazil the adoption of river basin as unit of management of the water resources is recent - after Federal Law no 9,433 approval, from 01/08/1997. São Paulo State has been usually precursory in this kind of initiative, but in this case it hasn't already been used all the necessary instruments for an appropriated management of this resource. Water scarcity is not only associated to the amount, but to the quality, taking in risk the quality of life of the current and future generations. The water quality is determined by impurities, came from different pollution sources as domestic sewage, industrials wastewater, urban and agricultural runoff, residues of mining activities etc., it's, associated to the kind of land use and land occupation. The available current tools do not make possible an adequate evaluation of non point source pollution. Therefore geotechnologies as Remote Sensing, Geographic Information Systems, Geographic Data Base, Global Positioning System, technologies of the InterNet and computational simulation environments, are available and they are more appropriated and sophisticated tools then traditional ones to must be used in studies that concern with preservation and recovery of the waters quality of river basins. This thesis aimed to develop and evaluate methodologies in a modern environment of decision support through the utilization of the available tools of Geotechnologies looking forward the conservation of environmental quality demonstrating its applicability to Paraíba do Sul River Basin . Using available data from this basin, it was possible to determine nonpoint source pollution added concerned to DQO and Suspended Solids parameters in a stretch part of the main river, identified as the parcel that is associated to rainfall events. The outflows associates to the land use and land cover and the polluting load of resultant diffuse origin were quantified, but it wasn't possible to identify the parcel of the Expected Mean Concentration of Rain Events - EMC for each land use and land cover. The 
final product achieved presented a good visual quality, but the most important result was the development of that methodology that could contribute to the advance of this kind of analysis because it was based on: easily upgrade data base, acquired data through a non invasive measurement techniques as Remote Sensing data, and the integration of spatial data through using a Geographic Information System - GIS.

Descriptors: river basin, non point source pollution, Geographic Information System, water quality, land use. 


\section{LISTA DE ILUSTRAÇÕES}

Figura 1 Uso e ocupação do solo e agentes alteradores de qualidade da água .... 07

Figura 2 Sub-bacias do Paraíba do Sul sobrepostas à Imagem de satélite trecho Sta Branca - Jacareí............................................................. 31

Figura 3 Mosaico de imagens da bacia paulista do Paraíba do Sul. 53

Figura 4 Sub-bacias de afluentes diretos do Paraíba do Sul no estado de São

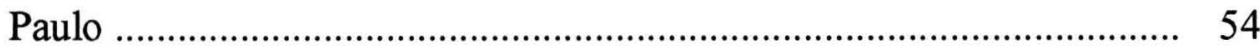

Figura 5 Diagrama unifilar dos aproveitamentos hídricos do Paraíba do Sul ..... 57

Figura 6 Postos fluviométricos e de descargas dos reservatórios na bacia paulista do Paraíba do Sul..................................................................... 58

Figura 7 Evolução da precipitação na sub-bacia do Paraíba do Sul.................... 59

Figura 8 Localização dos pontos de amostragem da CETESB na UGRHI-02.... 61

Figura 9 Fósforo total ao longo do rio Paraíba do Sul - CETESB (2004)

Figura 10 Número de coliformes fecais ao longo do rio Paraíba do Sul CETESB (2004) ..................................................................... 64

Figura 11 Condutividade ao longo do rio Paraíba do Sul - CETESB (2004)........ 65

Figura 12 Teor de oxigênio dissolvido ao longo do Paraíba do Sul - CETESB (2004)

Figura 13 Pontos de amostragem da CETESB e da UNESP nos cursos d'águas principais de São José dos Campos

Figura 14 Imagem de São José dos Campos.

Figura 15 Precipitação ao longo do ano de 2003 no município de São José dos Campos 76

Figura 16 Área de abrangência da região do estudo de caso... 78

Figura 17 Regiões hidrológicas semelhantes no Estado de São Paulo .................. 85

Figura 18 Regiões hidrológicas semelhantes quanto ao parâmetro $C_{7, m} \ldots \ldots \ldots \ldots . . \quad 87$

Figura 19 Representação do método de Thiessen ............................................ 88

Figura 20 Representação do método das isoietas ............................................... 89

Figura 21 Bacia do Paraíba do Sul, com destaque para São José dos Campos...... 96

Figura 22 Trecho de estudo e condições de contorno.......................................... 97

Figura 23 Região de estudo delimitada pelas sub-bacias.................................... 98 
Figura 24 Afluentes diretos do rio Paraíba do Sul na região de estudo e delimitação das sub-bacias................................................................. 99

Figura 25 Vazão ao longo do trecho paulista do rio Paraíba do Sul...................... 101

Figura 26 Carga de Alumínio encontrada ao longo do Paraíba do Sul.................. 102

Figura 27 Carga de DQO encontrada ao longo do Paraíba do Sul........................ 102

Figura 28 Carga de Fósforo total encontrada ao longo do Paraíba do Sul............ 103

Figura 29 Carga de NKT encontrada ao longo do Paraíba do Sul......................... 103

Figura 30 Carga de Resíduo Filtrável encontrada ao longo do Paraíba do Sul..... 104

Figura 31 Mosaico de imagens da bacia paulista do Paraíba do Sul, com destaque para a região de estudo.......................................................... 107

Figura 32 Uso e ocupação/cobertura do solo na região de estudo........................... 108 


\section{LISTA DE TABELAS}

Tabela 1 Relação entre uso do solo e concentração esperada de poluentes

Tabela 2 Descrição dos Pontos de Amostragem de qualidade de água da CETESB na bacia do Paraíba do Sul

Tabela 3 Uso e Ocupação/Cobertura do solo na bacia paulista do Paraíba do Sul.. 68

Tabela 4 Área urbana e rural do município de São José dos Campos .................... 75

Tabela 5 Projeção da população para os municípios pertencentes à área de influência da região estudada e UGRHI-2

Tabela 6 Relação dos estabelecimentos rurais e industriais e empregos nos municípios pertencentes à área de influência da região estudada e UGRHI-2, em 1998

Tabela 7 Parâmetros regionais a, b, XT, A e B para a UGRHI - 2

Tabela 8 Principais afluentes diretos ao Paraíba do Sul no trecho da região do estudo de caso

Tabela 9 Vazões médias de longo termo dos afluentes do Paraíba do Sul.

Tabela 10 Vazões ao longo do trecho de estudo do rio Paraíba do Sul.

Tabela 11 Precipitação mensal acumulada na área de estudo.

Tabela 12 Carga adicionada no trecho do estudo de caso e correlação com a pluviosidade.

Tabela 13 Resumo das vazões associadas ao uso e ocupação/cobertura do solo da região estudada.. 


\section{LISTA DE SIGLAS}

ABRH Associação Brasileira de Recursos Hídricos

AGPNS Agicultural Nonpoint Source Pollution Model

ANA Agência Nacional das Águas

ANSWERS Areal Nonpoint Source Watershed Environment Response Simulation

AQUAT Aquifer Attenuation model

BDG Bancos de Dados Geográficos

CBH Comitês de Bacias Hidrográficas

CBH-PS Comitê de Bacia Hidrográfica do Paraíba do Sul

CEIVAP Comitê de Integração do Rio Paraíba do Sul

CETESB Companhia de Tecnologia de Saneamento Ambiental

CME Concentração Média de Eventos de Chuva

CONAMA Conselho Nacional do Meio Ambiente

CORHI Comitê Coordenador do Plano Estadual de Recursos Hídricos

CPTI Cooperativa de Serviços e Pesquisas Tecnológicas e Industriais

CREAMS Chemicals, Runoff, and Erosion from Agricultural Management Systems

CRH Conselho Estadual de Recursos Hídricos

DAEE Departamento de Águas e Energia Elétrica do Estado de São Paulo

DBO Demanda Bioquímica de Oxigênio

DNAEE Departamento Nacional de Águas e Energia

DQO Demanda Química de Oxigênio

EMC Expected Mean Concentration (Concentração Média Esperada)

EPA Environmental Protection Agency

FEHIDRO Fundo Estadual de Recursos Hídricos

FUNDUNESP Fundação para o Desenvolvimento da UNESP

GPS Sistemas de Posicionamento Globais

GRASS Geographic Resources Analysis Support System

HSPF Hydrological Simulation Program-FORTRAN

IBGE Instituto Brasileiro de Geografia e Estatística

INPE Instituto Nacional de Pesquisas Espaciais

LOADSS Lake Okeechobee Agricultural Descision Support System 


$\begin{array}{ll}\text { MLT } & \text { Média de Longo Termo } \\ \text { MPO } & \text { Ministério do Planejamento e Orçamento } \\ \text { MUSLE } & \text { Equação Universal de Perda de Solo modificada } \\ \text { NPS } & \text { Non-Point Source } \\ \text { OD } & \text { Oxigênio Dissolvido } \\ \text { PERH } & \text { Plano Estadual de Recursos Hídricos } \\ \text { PI } & \text { Plano de Informação } \\ \text { PNMA } & \text { Política Nacional de Meio Ambiente } \\ \text { PQA } & \text { Projeto Qualidade das Águas } \\ \text { SGBD } & \text { Sistemas de Gerenciamento de Banco de Dados } \\ \text { SIBAC } & \text { Sistema Integrado } \\ \text { SIG } & \text { Sistemas de Informação Geográfica } \\ \text { SPRING } & \text { Sistema de Processamento de Informações Geográficas } \\ \text { SR } & \text { Sensoriamento Remoto } \\ \text { SWAT } & \text { Soil Water and Assessment Tool } \\ \text { TDT } & \text { Técnicas Dependentes do Tempo } \\ \text { TIN } & \text { Triangular Irregular Network } \\ \text { UGRHI } & \text { Unidade de Gerenciamento de Recursos Hídricos } \\ \text { UN } & \text { United Nations } \\ \text { UNESP } & \text { Universidade Estadual Paulista "Júlio de Mesquita Filho" } \\ \text { USLE } & \text { Universal Soil Loss Equation } \\ & \end{array}$




\section{ÍNDICE}

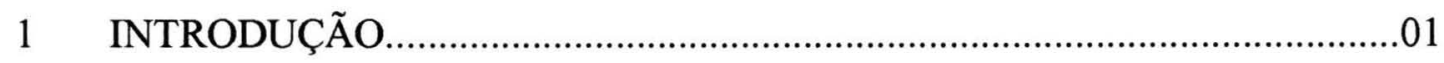

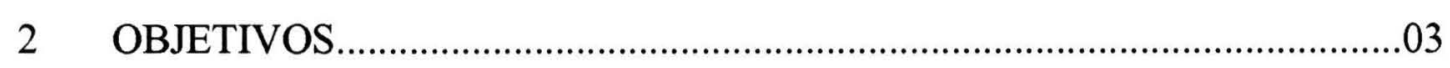

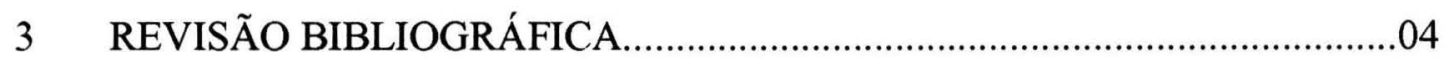

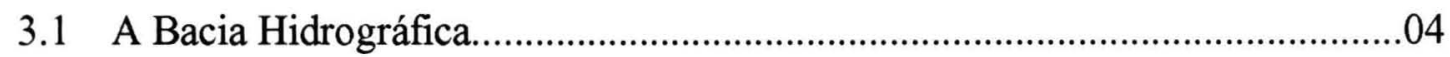

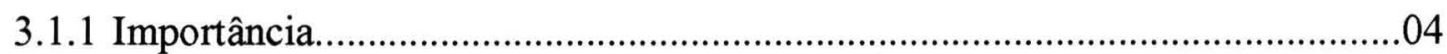

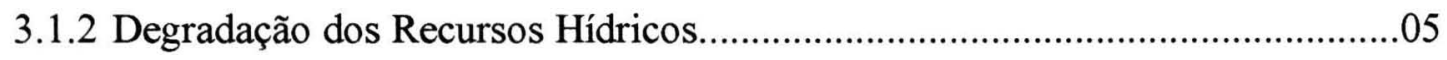

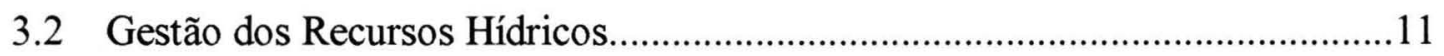

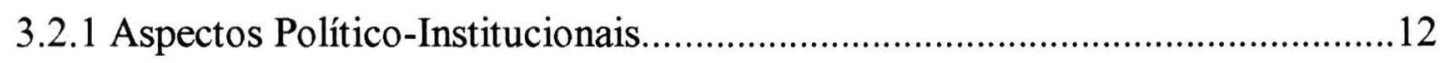

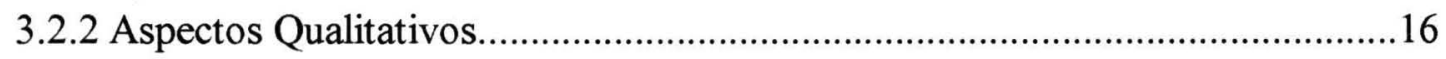

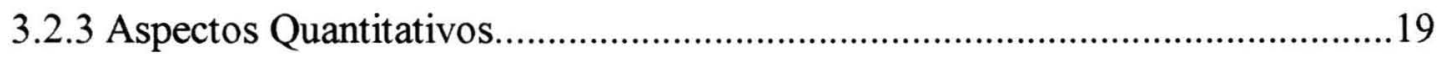

3.2.4 Controle de Fontes de Poluição..........................................................................

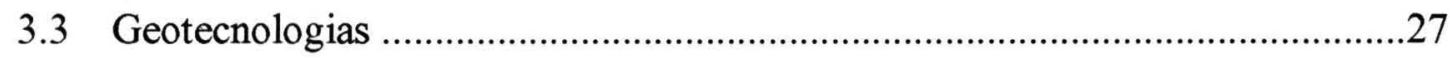

3.3.1 Descrição Geral de SIGs.............................................................................2

3.3.2 Organização de Trabalho em Ambiente SIG....................................................28

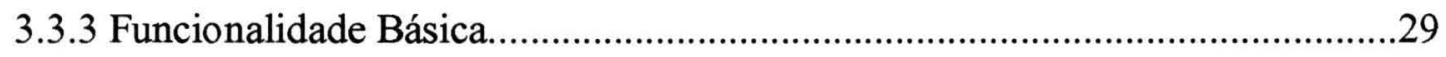

3.3.4 Modelos de Poluição de Fontes Pontuais.........................................................

3.3.5 Modelos de Poluição de Fontes Difusas.............................................................32

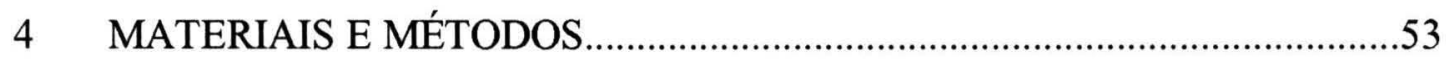

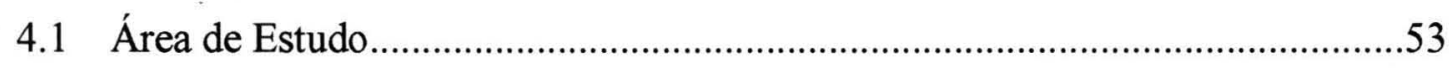

4.1.1 Os Recursos Hídricos na bacia Paraíba do Sul...............................................55

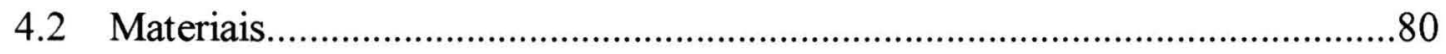

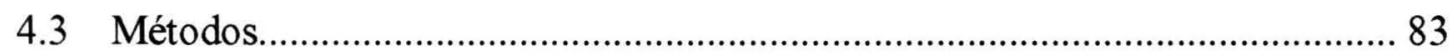

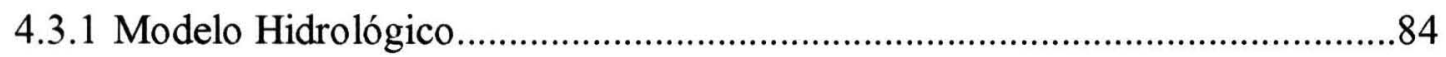

4.3.2 Modelo de Poluição de Fontes Difusas...........................................................90

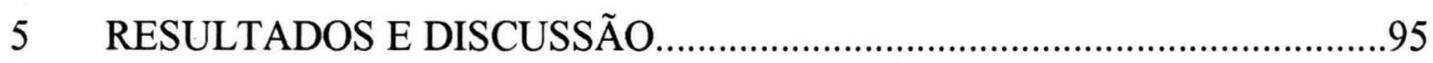

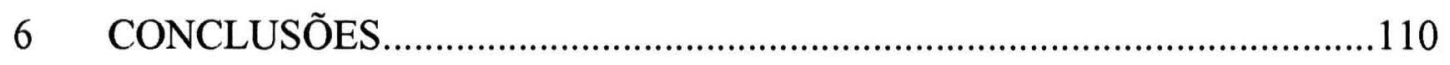

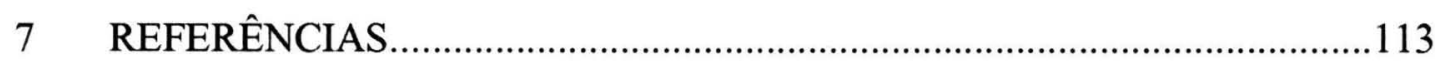




\section{ANEXOS}

Anexo 1 - Relação de sub-bacias de afluentes diretos do rio Paraíba do Sul em

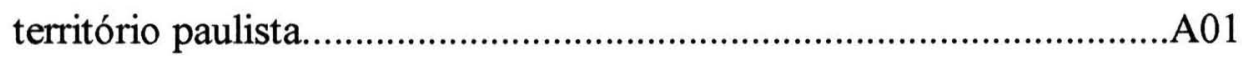

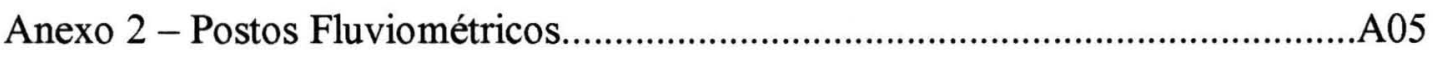

Anexo 3 - Dados de qualidade das águas do rio Paraíba do Sul ...........................A07

Anexo 4 - Vazões calculadas segundo método da regionalização hidrológica........A20

Anexo 5 - Carga de Poluentes no trecho paulista do rio Paraíba do Sul.................A33

Anexo 6 - Uso e ocupação/cobertura do solo por sub-bacias na região de estudo..A35 


\section{INTRODUÇÃO}

A Política Nacional de Recursos Hídricos define a bacia hidrográfica como a unidade territorial para o gerenciamento dos recursos hídricos, e que a água drenada nesta bacia deve ser gerenciada como um patrimônio público finito dotado de valor econômico. O gerenciamento dos recursos hídricos deve incluir usuários múltiplos e estar baseado num enfoque participativo com envolvimento do governo, dos próprios usuários e dos cidadãos.

O planejamento dos recursos hídricos de uma bacia hidrográfica consiste em identificar e viabilizar a implantação de ações, estruturais ou não, capazes de ajustar as características da água disponível no local de utilização àquelas exigidas por cada um dos usos. Um pré - requisito para este tipo de gerenciamento é ter acesso a dados de qualidade e quantidade, que manipuladas por eficientes ferramentas possibilitam:

- avaliação dos recursos hídricos,

- análise da utilização dos recursos,

- disseminação do entendimento de complexos problemas envolvidos na utilização dos recursos por pessoal não especializado.

A bacia do Paraíba do Sul localizada ao longo do eixo Rio-São Paulo é vetor de ligação e desenvolvimento de uma das mais importantes regiões econômicas da América do Sul. Apresenta superfície de $57.000 \mathrm{~km}^{2}$, aproximadamente; abrange 168 municípios nos três principais estados brasileiros (SP, RJ e MG); existem mais de 7.000 indústrias em sua área, serve de abastecimento a mais de 12 milhões de pessoas, incluindo 8 milhões só na região metropolitana do Rio de Janeiro (ICFKAISER e LOGOS 1999).

Fontes de poluição não pontuais, tais como: atividades agrícolas, runoff industrial e urbano, a combinação de transbordamentos e vazamentos do sistema de coleta de esgotos, depósitos de resíduos perigosos, sistemas de tanques sépticos, atividades de mineração e de corte de florestas, derramamentos, deposição atmosférica e modificações hidrológicas; representam contribuições significativas na alteração da qualidade das águas superficiais.

Com toda esta complexidade, a situação das bacias hidrográficas não é das melhores; em especial a do Paraíba do Sul onde são muitos os problemas em relação 
ao desmatamento, erosão, poluição industrial e doméstica, enchentes, saneamento básico, drenagem, problemas relacionados com a educação ambiental, o que certamente faz pensar que este modelo de desenvolvimento implementado até então em nossas bacias não é mais possível.

Portanto o gerenciamento de bacias hidrográficas implica em coletar e integrar dados de diversas naturezas, sendo obrigatoriamente um trabalho multidisciplinar.

Para assegurar, à atual e às futuras gerações, a necessária disponibilidade das águas, em padrões de qualidade adequados, há então a necessidade de ferramentas mais sofisticadas do que as usuais para antever os potenciais impactos que as ações planejadas possam provocar, em especial nas ocasiões onde são estabelecidas correlações entre cargas poluidoras e níveis de qualidade desejáveis nos corpos receptores.

As Geotecnologias (bancos de dados espaciais, sensoriamento e softwares SIG) combinadas com as técnicas de modelagem matemática são o suporte adequado ao processo de aquisição de conhecimento e tomada de decisão.

Busca-se assim, uma melhor compreensão técnica - científica sobre o gerenciamento dos recursos hídricos e suas repercussões, aliada a tecnologias de captação, armazenamento, recuperação, processamento, manipulação e transformação, conhecidas como geotecnologias, que permitem o desenvolvimento de metodologias para analisar informações ambientais integradamente no espaço geográfico.

Entre estas tecnologias encontramos o Sensoriamento Remoto - SR, os Sistemas de Informação Geográfica - SIG, os Bancos de Dados Geográficos - BDG, os Sistemas de Posicionamento Globais - GPS, as tecnologias da Internet e os ambientes computacionais para simulação.

Sistemas de Informação Geográfica - SIG têm sido utilizados, segundo BURROUGH (1998), em áreas relacionadas a questões ambientais tais como: erosão do solo, poluição marinha, diversidade biológica, pecuária, fornecimento de água potável, mudança climática, pobreza, urbanização, ou mudanças demográficas.

Portanto no âmbito do gerenciamento de recursos hídricos torna-se vital uma análise espacializada das fontes de poluição auxiliada por banco de dados atualizados, alimentadores de modelos de simulação de qualidade ambiental. 


\section{OBJETIVOS}

Compreender e mensurar as conseqüências, em termos de alterações da qualidade das águas superficiais, decorrentes do uso e ocupação do solo em bacias hidrográficas, utilizando ferramentas da Geotecnologia.

A Modernização tecnológica das ferramentas para o controle da poluição implica no desenvolvimento de uma metodologia de trabalho num ambiente de suporte à decisão mais amplo que prevê a integração com ferramentas de geoprocessamento, modelagem matemática, recursos de sensoriamento e aquisição remota de dados e disseminação de informações via Internet/Intranet/Extranet. Para tanto devem ser dados os seguintes passos:

- revisar as ferramentas de Geotecnologias atuais disponíveis para a proteção da qualidade ambiental, em especial aquelas que dizem respeito à avaliação voltada para a preservação e recuperação da qualidade das águas superficiais de bacias hidrográficas;

- avaliar a aplicabilidade de modelos baseados em SIG utilizados para estimar a poluição de fontes não pontuais e para simular a qualidade das águas superficiais decorrentes do aporte de cargas tanto pontuais como difusas;

- avaliar o papel das fontes de poluição não pontuais (ou difusas), associadas a períodos ou eventos de maior intensidade pluviométrica, na qualidade das águas superficiais;

- dispor de ferramenta capaz de avaliar a alocação de cargas poluidoras para atender aos padrões de qualidade estabelecidos pela legislação e a comparação da efetividade das medidas de controle de poluição requeridas face à disponibilidade hídrica.

Cabe ressaltar que o objetivo deste trabalho vai de encontro a um dos objetivos específicos identificado no Plano de Qualidade das Águas e Controle de Poluição Hídrica na bacia do rio Paraíba do Sul (ICF-KAISER e LOGOS 1999), a ser perseguido pela agência da bacia, que é dotá-la de um Sistema de informações sobre recursos hídricos e meio ambiente, que faz parte das bases técnicas para o seu adequado gerenciamento, devendo ser periodicamente atualizado. 


\section{REVISÃO BIBLIOGRÁFICA}

\subsection{A Bacia Hidrográfica:}

\subsubsection{Importância}

As águas doces podem definir o desenvolvimento de uma região urbanizada pela quantidade e qualidade de seu suprimento. A sua característica de recurso natural renovável tem sido interpretada como de recurso inesgotável da natureza, passível de ser tecnologicamente domesticado em benefício da sociedade: saciando a sede e carregando para longe o indesejável.

A importância absoluta da água potável, aliada às alterações de suprimento hídrico no tempo e no espaço, é responsável pelas primeiras tentativas da sociedade humana de modificar o ambiente natural: "Na verdade, o desenvolvimento da agricultura e da sociedade organizada sempre esteve vinculado ao controle da água, especialmente para irrigação. As civilizações do antigo Egito e da China, assim como da Índia e da Mesopotâmia, chamam-se 'civilizações hidráulicas'. Sua ascensão e subseqüente queda estão intimamente relacionadas ao uso e abuso da água" (DREW 1986, p. 87).

As finalidades definidas para as águas variam no tempo e nas quantidades a serem demandadas. A cultura urbano-industrial entendendo a água como recurso inesgotável, gera demandas hídricas de crescimento exponencial, obrigando a uma procura contínua por fontes hídricas. Qualquer função urbana - residencial, comercial ou industrial - depende prioritariamente da existência da água para atender às suas necessidades, tanto pela utilização direta, como dessedentação, quanto indireta, como a produção de energia hidráulica.

Os conflitos entre as necessidades humanas e as do ecossistema natural ampliam-se em relação direta com o crescimento e concentração populacional nas áreas urbanas.

Conforme estimativas das Nações Unidas (UN 2003), 8 \% do total anual de água doce renovável são captadas e nos apropriamos de $26 \%$ da evapotranspiração anual e de $54 \%$ do runoff disponível. Estima também que a produção global de 
efluentes é de $1.500 \mathrm{Km}^{3}$. Assumindo que 1 litro de efluente polui 8 litros de água doce, o volume de águas poluídas ao redor do mundo pode ser superior a 12.000 $\mathrm{Km}^{3}$.

\subsubsection{Degradação dos Recursos Hídricos}

As intervenções humanas no ciclo da água têm negligenciado a relação entre o elemento água e seu entorno natural, provocando impactos diretos ou indiretos de três ordens: mudanças na superfície terrestre, poluição e retiradas consumptivas.

A mudança na superfície terrestre, principalmente com a impermeabilização, aumenta o fluxo de escoamento superficial, pois reduz a percolação para os depósitos subterrâneos, provocando enchentes e erosão com carreamento de toda sorte de resíduos sólidos. Além disso, a diminuição da recarga dos depósitos subterrâneos pode ter conseqüências graves em regiões bem distantes - local de afloramento das águas.

O ciclo hidrológico pode agir como um agente disseminador de poluentes pela biosfera. Os poluentes lançados na atmosfera precipitam na superfície como chuva contaminada. Os produtos químicos usados na superfície - agrotóxicos, óleos e graxas, por exemplo - lixiviam para os depósitos subterrâneos e/ou compartimentos de superfície, como também ocorre com os resíduos sólidos abandonados. Algumas atividades, como a irrigação, têm caráter consumptivo, alterando as relações locais dos círculos do ciclo hidrológico. Fenômeno semelhante ocorre com as reversões de água entre bacias hidrográficas.

Os recursos hídricos são utilizados como se não fizesse parte de um sistema natural, um ecossistema, onde os elementos se inter-relacionam.

A urbanização apesar de ocupar uma pequena área em uma grande bacia hidrográfica promove alterações significativas numa grande região. $\mathrm{O}$ processo de urbanização resulta, segundo MOTA (1981), em modificações sobre o meio ambiente, como conseqüência de:

- alterações no ambiente terrestre, necessárias a implantação da cidade. Exemplos: movimentos de terra; desmatamentos; desvios de cursos d'água;

- utilização dos recursos naturais, como fonte de matéria e energia necessárias 
às atividades humanas. Exemplos: captação de água para abastecimento público e outros usos; queima de materiais para produção de energia; obtenção de matéria-prima para processos industriais;

- lançamento, no ambiente, de resíduos resultantes de processos biológicos do homem ou de atividades que ele desenvolve na cidade. Exemplos: gases expelidos por veículos automotores ou provenientes de processos industriais; esgotos domésticos e resíduos líquidos industriais; resíduos sólidos de diversas procedências.

Portanto, uma vez que as águas superficiais drenam para uma seção de saída de uma bacia ou sub-bacia, caracterizada como a área de terreno drenada por uma corrente, e delineada pela topografia, as atividades que se desenvolvem no terreno à montante afetam tanto a qualidade como a quantidade da água neste ponto. A figura 1 a seguir ilustra a inter-relação de uso e ocupação do solo e agentes alteradores de qualidade da água.

Para a adoção de medidas de controle da poluição, é necessário conhecer como a mesma ocorre, suas fontes e processos. Isto é muito importante principalmente, na implantação de medidas preventivas de controle. As fontes podem ser classificadas em:

a) Fontes localizadas de poluição da água:

- lançamento de esgotos domésticos (sanitários);

- lançamento de esgotos industriais;

- lançamento de águas pluviais, através das galerias.

b) Fontes não localizadas de poluição da água:

- água de escoamento superficial, oriunda de atividades agrícolas, runoff urbano e industrial, de atividades de mineração e de corte florestal, derramamentos, deposição atmosférica e modificações hidrológicas;

- água de infiltração, oriunda da combinação de extravasamento e vazamento de coletor de esgoto, de aterro de resíduos perigosos, sistemas de tanques sépticos;

- lançamento direto de resíduos sólidos e outras impurezas; 
- introdução de água salgada.

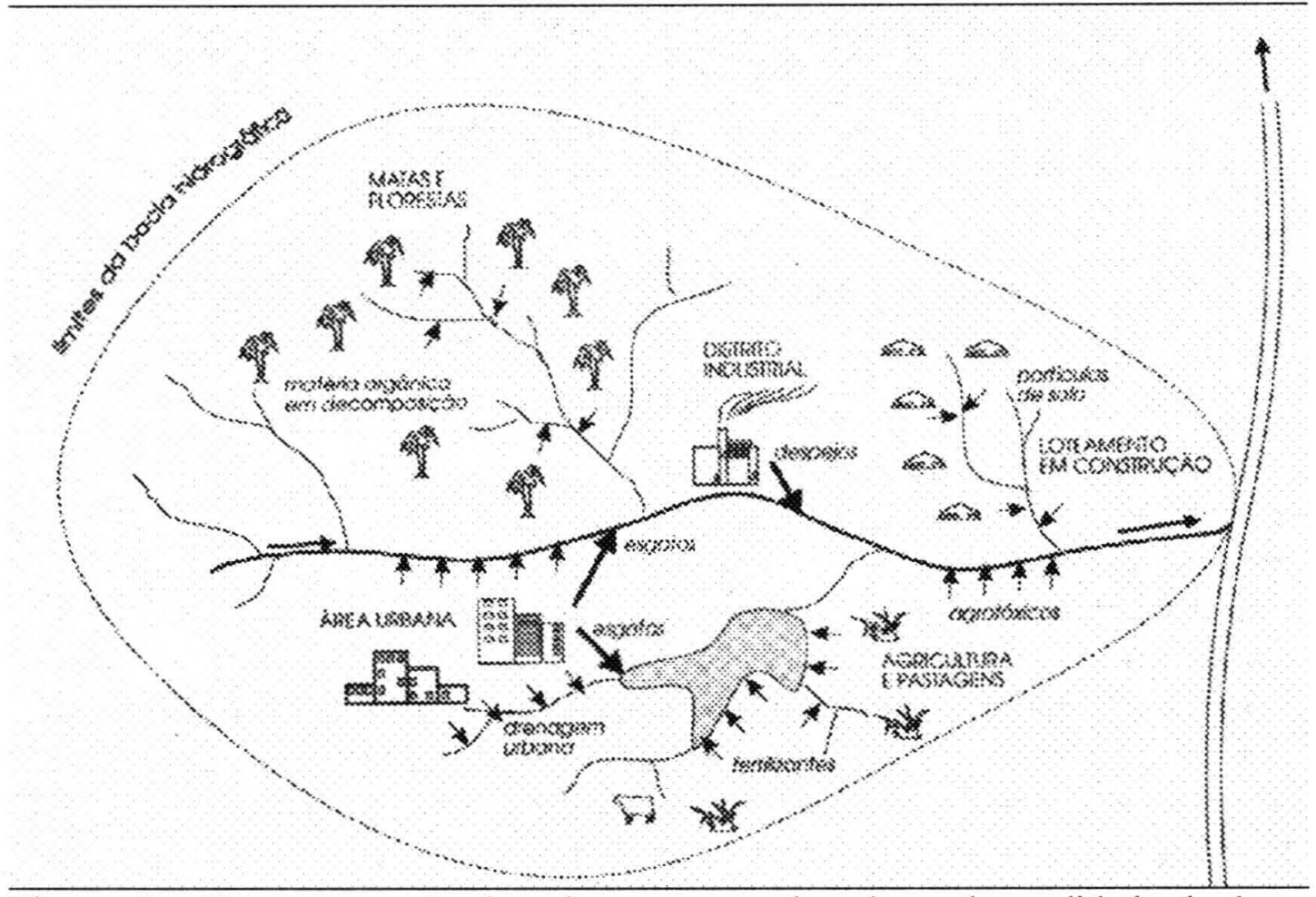

Figura 1 - Uso e ocupação do solo e agentes alteradores de qualidade da água. Fonte: von SPERLING (1996).

a) Fontes localizadas de poluição da água.

Os esgotos domésticos caracterizam-se pela grande quantidade de matéria orgânica que contêm, o que causa redução do oxigênio dissolvido na água que os recebe, como resultado de sua estabilização pelas bactérias.

Como os resíduos dos processos biológicos do homem estão contidos nos esgotos domésticos, normalmente os mesmos possuem bactérias e organismos patogênicos.

Os esgotos domésticos provocam outras alterações nas características da água, relacionadas com a cor, turbidez, odor, sólidos, compostos químicos, entre outros.

Os esgotos industriais têm composição bastante variada, dependendo do tipo de processamento utilizado. De um modo geral, podemos dizer que alguns resíduos líquidos industriais são caracterizados por: 
- Demanda Bioquímica de Oxigênio elevada, causando a redução do oxigênio dissolvido da água;

- presença de compostos químicos tóxicos e metais pesados;

- cor, turbidez e odor indesejável;

- temperatura elevada, provocando desequilíbrios ecológicos no corpo receptor;

- nutrientes em excesso, causando a eutrofização da água, com prejuízos aos seus usos;

- sólidos dissolvidos e em suspensão;

- ácidos e álcalis, com efeitos sobre o pH da água;

- óleos, graxos e similares.

b) Fontes não localizadas de poluição da água.

\section{Áreas Urbanas}

A água que precipita em uma área urbana e escoa pela superficie pode conduzir uma grande variedade de impurezas. A concentração de impurezas neste liquido é bastante variável e depende, principalmente, de:

- uso do solo: residencial, comercial, industrial ou outros;

- atividades desenvolvidas pelo homem, na área: construções, movimentos de terra, tráfego de veículos, etc;

- fatores hidrológicos: duração, quantidade e freqüência da precipitação pluvial;

- características do ambiente físico: área pavimentada ou coberta, tipo de pavimentação ou cobertura, vegetação presente, estrutura e composição do solo.

As fontes de poluição e formas como atingem os corpos d'águas são descritas a seguir: 
- esgotos domésticos: afluem aos cursos d'água por meio de lançamentos diretos (como em favelas situadas nas margens), descargas permanentes ou acidentais do sistema de coleta e interceptação, ligações clandestinas no sistema de águas pluviais (de todo um domicílio ou parte dele, como instalações sanitárias externas, áreas de lavanderia ou cozinhas), efluentes de fossas sépticas não ligados a sumidouros ou em áreas;

- efluentes líquidos de estabelecimentos comerciais e de serviço (padarias, restaurantes, postos de gasolina, oficinas mecânicas, garagens de ônibus, etc.) e pequenas indústrias (galvanoplastia, serralherias, outras) lançados diretamente ou através do sistema de drenagem; dão origem a cargas orgânicas, metais, óleos e graxas, solventes, entre outros;

- resíduos sólidos: lançamento direto no leito dos cursos de água ou na rede drenagem pluvial, de lixo doméstico e de atividades comerciais (como feiras livres, mercados, etc.) e industrias;

- movimento de veículos: resíduos originados no desgaste de pavimentos, resíduos de pneus, óleos, lubrificantes, graxas são depositados na superfície das vias públicas e carreados aos cursos de água durante os eventos de chuva;

- lavagem de superfícies: quintais e jardins, calçadas, ruas e grandes áreas;

- erosão de áreas com solo nu, ou durante trabalhos de terraplenagem;

- lavagem de materiais de construção (areia, cimento, cal, etc.) em obras públicas ou construções particulares (abertura de loteamentos, construção de edificações, etc.);

\section{Áreas Rurais}

- atividades agrícolas: as cargas dependem do tipo de cultura, da fase em que se encontra o ciclo de produção (preparação do terreno, semeadura, desenvolvimento das plantas, colheita, etc.), e do uso de fertilizantes e defensivos; o aporte de cargas aos cursos de água está fundamentalmente associado à ocorrência de eventos de chuva;

- atividades pecuárias: as cargas dependem do tipo de criação e das técnicas 
utilizadas;

- mineração: são de alto potencial poluidor, dependendo do tipo de minério em exploração e da adoção de técnicas adequadas de proteção e controle ambiental; estão associadas tanto às características operacionais da atividade quanto à ocorrência de eventos de chuva;

- chácaras de recreação e lazer: esgotos domésticos e lixo gerados nas atividades domésticas e cargas de pequenas áreas cultivadas;

- áreas naturais pouco alteradas como matas, capoeiras, campo: produzem cargas devido à decomposição de matéria orgânica vegetal, carreadas aos cursos de água através do escoamento superficial.

\section{Deposição Atmosférica}

- partículas em suspensão no ar: deposição na superfície de telhados, calçadas e ruas, e diretamente na superficie dos corpos de água; a natureza das partículas poluentes depende do grau de poluição atmosférica e de suas fontes, que podem estar a distâncias significativas das áreas de deposição; podem conter enxofre, metais, compostos orgânicos, nutrientes, entre outros;

- água de chuva: partículas, gases e outros contaminantes atmosféricos dissolvem-se nas águas de chuva ou são arrastadas por ela até a superfície do solo;

De modo geral, as águas de escoamento superficial podem ser caracterizadas por:

- sólidos sedimentáveis, de vários tipos e tamanhos;

- matéria orgânica;

- nutrientes, principalmente fósforo e nitrogênio;

- defensivos agrícolas e fertilizantes;

- bactérias e organismos patogênicos;

- vários compostos químicos; 
- metais pesados.

Este líquido, atingindo coleções superficiais ou infiltrando-se no terreno até alcançar a água subterrânea, pode resultar em:

- efeitos negativos sobre a saúde humana;

- diminuição do oxigênio da água;

- danos ecológicos, com reflexos sobre a fauna e a flora aquáticas;

- assoreamento;

- excessiva turbidez;

- eutrofização.

PUCKETT (1995) identificou que nos EUA as fontes não pontuais eram as dominantes em relação a nitrogênio e fósforo na maioria das correntes estudadas. Ainda verificou que o aporte de nutrientes nas bacias varia com a prática de uso do solo, sendo que o nitrogênio atmosférico pode ser a maior fonte de poluição, assim como as fontes pontuais podem representar o maior problema em relação à qualidade da água.

\subsection{Gestão dos Recursos Hídricos}

Este tratamento, que tem sido dado ao meio natural, é resultado de uma perspectiva de desenvolvimento, que entende os bens naturais renováveis como recursos inesgotáveis, tendo seu uso ampliado pela capacidade humana em transformá-los e otimizá-los através do desenvolvimento de processos tecnológicos. Entretanto, estilo de desenvolvimento, que privilegia as relações econômicas da sociedade com o meio, tem uma resultante antrópica que coloca em risco as possibilidades futuras dos diversos segmentos sociais. Neste contexto, as premissas de desenvolvimento, enquanto processo de transformação sócio-econômica, está sendo reavaliado, incorporando os limites de uso dos bens naturais, impostos pelas relações ecológicas e os valores dos diversos segmentos sociais. Desenvolvimento passa, então, a ser discutido pela perspectiva de sua sustentabilidade.

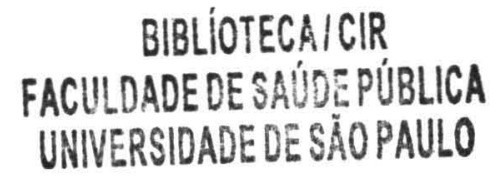


Cada função urbana demanda um conjunto de intervenções que causa impactos de ordens diversas - de positivo a negativo - na bacia hídrica de uma região urbanizada. Reconhecer estes impactos e sua dimensão é mister para a promoção do planejamento das águas doces, enquanto recurso natural estratégico para a sustentabilidade do desenvolvimento das regiões metropolitanas.

O uso do solo é o elo de ligação entre os sistemas sócio-econômico e natural. O planejamento ambiental visa reordenar o uso do solo de maneira que a intervenção humana seja a menos impactante, ou seja, que represente a menor taxa de alterações possíveis (CAUBET E FRANK 1993).

Segundo LEAL (1998), os instrumentos para a gestão ambiental são de duas naturezas: de comando e controle e instrumentos econômicos.

Os instrumentos de comando e controle correspondem aos sistemas onde o poder público estabelece os padrões e monitora a qualidade ambiental, regulando as atividades e aplicando sanções e penalidades, via legislação e normas. Já os instrumentos econômicos se utilizam de mecanismos de mercado, que vão traduzir, via preços e custos, a escassez dos recursos naturais ou os danos ambientais decorrentes do processo em questão.

$\mathrm{Na}$ Política Nacional de Meio Ambiente - PNMA, estabelecida pela lei $\mathrm{n}^{\circ}$ 6.938 (BRASIL, 1981), os instrumentos de comando e controle são classificados em quatro categorias: padrões ambientais (de qualidade e de emissão); controle de uso do solo (zoneamento e áreas de proteção); licenciamento (estudo de impacto ambiental); e penalidades (multas, compensações, etc.). Além desses instrumentos previstos na PNMA há outros que também podem ser utilizados num processo de gestão ambiental, destacando-se auditoria ambiental, outorga de direito de uso e regulamentação de uso.

\subsubsection{Aspectos Político-Institucionais}

A Lei Federal $n^{\circ} 9.433$ (BRASIL 1997) veio dispor sobre a Política Nacional de Recursos Hídricos e instituir Sistema Nacional de Recursos Hídricos, disciplinando sua outorga, a cobrança por seu uso (derivação e lançamento de efluentes), rateio de custos e instituindo penalidades. 


\section{Aspectos Relevantes da Política Nacional de Recursos Hídricos}

a) Princípios básicos:

- Adoção da Bacia Hidrográfica como unidade de planejamento - o gerenciamento de uma bacia não diz respeito apenas ao curso hídrico, mas também à área em seu entorno e a todos os problemas ambientais que podem degradar o curso hídrico.

- Uso múltiplo da água - todos os setores de usuários terão igual acesso aos recursos hídricos, acabando com a predominância que o setor elétrico tinha sobre a gestão dos mesmos.

- A água é um bem finito e vulnerável.

- A água tem valor econômico - o que deve induzir a uma utilização mais racional e à instituição da cobrança pelo uso da água.

- Gestão descentralizada e participativa - participação de todos os usuários da sociedade civil organizada, das empresas, das ONGs e outros organismos que possam influenciar na tomada de decisões sobre os planos de melhoria das bacias hidrográficas.

b) Instrumentos para uma melhor gestão do uso da água:

- Plano Nacional de Recursos Hídricos - programa de atualização e consolidação dos chamados Planos Diretores de Recursos Hídricos, elaborados por bacias (ou conjunto de bacias) hidrográficas.

- Outorga de Direito de Uso dos Recursos Hídricos - instrumento pelo qual o usuário recebe uma autorização ou uma concessão para fazer uso da água.

- Cobrança pelo uso da água - instrumento que deverá servir para criar as condições de equilíbrio entre as forças de oferta e da demanda, promovendo a harmonia entre os usuários competidores. 
- Enquadramento dos corpos d'água em classes de uso - importante para se estabelecer um sistema de vigilância sobre os níveis de qualidade da água dos mananciais.

- Sistema Nacional de Informações sobre Recursos Hídricos - encarregado de coletar, organizar, criticar e difundir a base de dados relativa aos recursos hídricos, podendo promover desta forma informação a todos os usuários da bacia e ajudando na tomada de decisões.

c) Organismos para a gestão compartilhada dos recursos hídricos:

- Conselho Nacional de Recursos Hídricos - com poder de decisão sobre as grandes questões do setor.

- Comitês de Bacias Hidrográficas - compostos pelos usuários, pelas prefeituras, por representantes dos governos federal e estadual e pela sociedade civil organizada, denominando-se parlamento das águas da bacia.

- Agências da Água - braço técnico dos comitês.

- Organizações civis de recursos hídricos - entidades atuantes no setor de planejamento e gestão do uso da água.

No Estado de São Paulo, a matéria está disciplinada através da lei no. 7.663 (SÃO PAULO 1991), que dispõe sobre a Política Estadual de Recursos Hídricos e sobre o Sistema Estadual de Recursos Hídricos. A outorga foi disciplinada pelo decreto Estadual no. 41.258 (SÃO PAULO 1996) e o uso dos recursos hídricos superficiais e subterrâneos é objeto da Portaria no. 717 DAEE (1996).

No Estado de São Paulo, a Política Estadual de Recursos Hídricos estrutura-se com base em três instrumentos:

a) O Plano Estadual de Recursos Hídricos (PERH), que é elaborado através de processo de planejamento interativo, tomando-se por base os planos por bacias hidrográficas, e estabelece as diretrizes gerais, a nível estadual e inter-regional, para a utilização e conservação dos recursos hídricos do estado; 
b) O Sistema Estadual de Recursos Hídricos, composto em suas várias instâncias de decisão por representantes do estado, municípios e sociedade civil:

- Conselho Estadual de Recursos Hídricos (CRH): órgão máximo do Sistema, tem como atribuições aprovar o PERH e os relatórios anuais do estado, exercer funções normativas, estabelecer diretrizes para a aplicação do Fundo Estadual de Recursos Hídricos (FEHIDRO) e dirimir eventuais conflitos entre Comitês de Bacias;

- Comitês de Bacias Hidrográficas (CBH). Suas atribuições principais são: aprovar o Plano da Bacia Hidrográfica, seus relatórios anuais e a proposta de aplicação dos recursos financeiros, bem como promover entendimento, cooperação e eventual conciliação entre os usuários dos recursos hídricos das bacias;

- Comitê Coordenador do Plano Estadual de Recursos Hídricos (CORHI): criado para dar suporte técnico às decisões do CRH e dos CBH's. Deverá coordenar a elaboração periódica do PERH e dos Planos das Bacias Hidrográficas, promover a integração entre os participantes do sistema e a articulação com os demais sistemas do estado, com o setor produtivo, a sociedade civil, outros estados e a união;

- Agências de Bacias: em bacias hidrográficas onde os problemas dos recursos hídricos atinjam complexidade e dimensão que as justifiquem, serão criadas as Agências de Bacia, cujas atribuições são semelhantes às do CORHI, além de gerenciar os recursos financeiros do FEHIDRO pertinentes à bacia.

c) O FEHIDRO, que dará suporte financeiro à execução da Política e dos Planos Estadual e de Bacias Hidrográficas. Dentre os recursos desse fundo destacam-se os provenientes do estado, da união e dos municípios, 
empréstimos externos e o resultante da cobrança pelo uso da água, que deverá ser aplicado nas bacias onde for arrecadado.

\subsubsection{Aspectos Qualitativos}

As condições de qualidade de um corpo d'água envolvem dois fatores fundamentais, segundo TUCCI (1998):

- condições hidrológicas: representam o estado do corpo de água quanto à quantidade de água. Em um rio esta condição é retratada pela vazão;

- qualidade da água: a concentração de um parâmetro de qualidade da água associada à vazão é a carga existente no sistema. A concentração isoladamente não tem representatividade temporal e espacial já que a mesma se altera com a vazão envolvida.

A qualidade das águas é determinada pelas impurezas presentes, introduzidas

por fontes de poluição, entre as quais se destacam os efluentes domésticos, os efluentes industriais, o deflúvio superficial urbano e o deflúvio superficial agrícola, resíduos de atividades de mineração etc., estando, portanto, associada ao tipo de uso e ocupação do solo.

Dentre os parâmetros químicos representativos da qualidade da água, conforme citado por SARMENTO e col. (1999) alguns são considerados conservativos e outros não conservativos. Os conservativos são aqueles que não sofrem transformações químicas e biológicas, mas se acumulam sendo apenas diluídos e não assimilados pelo corpo d'água.

A qualidade das águas não se relaciona necessariamente à sua pureza, sendo considerada boa ou ruim para um determinado uso. Os principais usos da água encontram-se na classificação das águas interiores do Estado de São Paulo descritos pelo Decreto Estadual no 8.468 (SÃO PAULO 1976):

Classe 1 - águas destinadas ao abastecimento doméstico, sem tratamento prévio ou com simples desinfecção; 
Classe 2 - águas destinadas ao abastecimento doméstico, após tratamento convencional, à irrigação de hortaliças ou plantas frutíferas e à recreação de contato primário (natação, esqui-aquático e mergulho);

Classe 3 - águas destinadas ao abastecimento doméstico, após tratamento convencional, à preservação de peixes em geral e de outros elementos da fauna e da flora e a dessedentação de animais;

Classe 4 - águas destinadas ao abastecimento doméstico, após tratamento avançado, ou à navegação, à harmonia paisagística, ao abastecimento industrial, à irrigação e a usos menos exigentes.

Para cada tipo de uso é necessário que a água apresente requisitos específicos. Em corpos d'água classe 2, conforme artigo $11^{\circ}$, do Decreto Estadual no 8.468 (SÃO PAULO 1976): "não poderão ser lançados efluentes, mesmo tratados, que prejudiquem sua qualidade pela alteração dos seguintes parâmetros ou valores:" Demanda Bioquímica de Oxigênio até $5 \mathrm{mg} / \mathrm{l}$ e Oxigênio Dissolvido não inferior a 5 $\mathrm{mg} / 1$, entre outros parâmetros.

No estado de São Paulo o enquadramento dos corpos d'água é definido pelo Decreto Estadual n ${ }^{\circ} 10.755$ (SÃO PAULO 1977).

Em 1986, a Resolução n 20 do Conselho Nacional do Meio Ambiente CONAMA estabeleceu uma nova classificação para as águas doces, bem como para as águas salobras e salinas do Território Nacional, sendo substituída em 2005 pela Resolução CONAMA no 357 (BRASIL 2005). Nesta são definidas treze classes, segundo os usos preponderantes a que as águas se destinam. As águas doces, em particular, são distribuídas em cinco classes:

CLASSE ESPECIAL - águas destinadas:

a) ao abastecimento para consumo humano, com desinfecção;

b) à preservação do equilíbrio natural das comunidades aquáticas; $\mathrm{e}$

c) à preservação dos ambientes aquáticos em unidades de conservação de proteção integral.

CLASSE 1 - águas que podem ser destinadas:

a) ao abastecimento para consumo humano, após tratamento simplificado; 
b) à proteção das comunidades aquáticas;

c) à recreação de contato primário, tais como natação, esqui aquático e mergulho conforme Resolução CONAMA n. 274 (BRASIL 2000);

d) à irrigação de hortaliças que são consumidas cruas e de frutas que se desenvolvam rentes ao solo e que sejam ingeridas cruas sem remoção de película; e

e) à proteção das comunidades aquáticas em Terras Indígenas.

CLASSE 2 - águas que podem ser destinadas:

a) ao abastecimento para consumo humano, após tratamento convencional;

b) à proteção das comunidades aquáticas;

c) à recreação de contato primário, tais como esqui aquático, natação e mergulho, conforme Resolução CONAMA n. 274 (BRASIL 2000);

d) à irrigação de hortaliças, plantas frutíferas e de parques, jardins, campos de esporte e lazer, com os quais o público possa vir a ter contato direto; e

e) à aqüicultura e à atividade de pesca.

CLASSE 3 - águas que podem ser destinadas:

a) ao abastecimento para consumo humano, após tratamento convencional ou avançado;

b) à irrigação de culturas arbóreas, cerealíferas e forrageiras;

c) pesca amadora;

d) recreação de contato secundário; e

e) à dessedentação de animais.

CLASSE 4 - águas que podem ser destinadas:

a) à navegação; $\mathrm{e}$

b) à harmonia paisagística.

A adequação da legislação estadual à legislação federal é necessária, e envolve uma reavaliação do enquadramento dos corpos de água do Estado de São Paulo, 
frente à classificação estabelecida pela Resolução CONAMA 357 (BRASIL 2005). Esse enquadramento deve se basear em diagnósticos regionais, considerando dados sócio-econômicos, uso do solo e usos pretendidos dos recursos hídricos.

No processo de gestão esse instrumento é muito importante, pois traduz as diretrizes de uso definidas pela sociedade e pelos órgãos gestores para os corpos d'água e estabelece as correspondentes classes de uso e metas de qualidade adequadas. Dessa forma, está intimamente ligado ao planejamento do uso do solo e também ao zoneamento ambiental. Para o estabelecimento do enquadramento é necessário pesquisar os usos ao qual se destina o corpo d'água, tanto usos atuais quanto potenciais. $\mathrm{O}$ enquadramento do corpo d'água se constitui num instrumento legal, sujeito a revisões periódicas conforme evolua a situação da bacia. Posteriormente é necessário diagnosticar a situação vigente para avaliar quão distante se está da meta desejada. Muitas vezes se detecta que alguns cursos d'água estão totalmente em desacordo com os usos praticados, quanto mais quando estão previstos novos usos mais exigentes.

Esse instrumento é muito valioso para subsidiar os planos de recursos hídricos, porque traduzem em última análise as metas de qualidade para a bacia.

Os custos envolvidos num processo de enquadramento são relativamente altos, devido ao trabalho de monitoramento para diagnóstico da situação atual e aos levantamentos necessários para o estabelecimento de metas.

\subsubsection{Aspectos Quantitativos}

O modelo mais simples em hidrologia é a chamada equação do balaço hídrico, sobre um determinado intervalo de tempo, para uma dada bacia hidrográfica:

$\mathrm{P}-\mathrm{ET}=\mathrm{D}+\Delta \mathrm{S}$

onde,

P - precipitação;

ET - evapotranspiração;

D - deflúvio;

$\Delta$ S- variação do armazenamento (superficial e/ou subterrâneo). 
Essa equação nada mais é do que a equação da continuidade, colocando em evidência as variáveis hidrológicas mais importantes, sendo que, para efeito de medida, o deflúvio é normalmente substituído pela vazão. Essas variáveis podem ser medidas diretamente ou indiretamente.

Portanto há a necessidade de se medir uma série de variáveis hidrológicas e meteorológicas para permitir o conhecimento das características hidrológicas e para possibilitar a aplicação de modelos matemáticos que permitem prever chuvas e/ou vazões ou então estimar a probabilidade associada a eventos raros.

Além disso, em decorrência da variação espacial considerável dessas grandezas, necessita-se, para se caracterizar uma bacia hidrográfica, de várias estações distribuídas sobre a sua superficie, ou seja, uma rede de observação formada por estações pluviométricas, fluviométricas, sedimentométricas e metereológicas.

Um dos primeiros modelos apresentados para representar o escoamento superficial na bacia foi o do hidrograma unitário. Ele é um processo de transformação de precipitação efetiva em escoamento superficial através de um método linear. Segundo TUCCI (1998) a metodologia de estimativa das ordenadas do hidrograma unitário identifica se o modelo é conceitual ou empírico.

Conforme TUCCI (1998) "a escolha do modelo depende dos objetivos do seu uso, da quantidade de dados disponíveis, das características da bacia e sua ocupação, da familiaridade do usuário com o modelo e do orçamento e cronograma previstos".

\section{Regionalização Hidrológica}

É definida pela Associação Brasileira de Recursos Hídricos - ABRH (1987), como qualquer processo de transferência de informações das estações pluvio e fluviométricas para outros locais em geral sem observações.

O valor esperado de vazões e precipitações é mais conhecido pela designação média de longo termo (MLT) e constitui um parâmetro importante para a obtenção de outras características (máximos e mínimos, por exemplo) através de diversos modelos matemáticos.

O modelo mais simples de regionalização é o tradicional mapa de isoietas médias anuais. 


\subsubsection{Controle de Fontes de Poluição}

Dentre os sistemas administrativos de controle, DERÍSIO (1992) destaca aquele baseado em padrões de qualidade das águas receptoras, o baseado na melhor tecnologia disponível e o baseado nos padrões de emissão uniformes.

O primeiro sistema mencionado considera o controle como sendo exercido pelo corpo receptor em função de padrões de qualidade estabelecidos com base em dados históricos de qualidade e critérios de qualidade para os usos que se pretende garantir para os cursos d'água.

Esse modo de controle, baseado unicamente nos padrões de qualidade, é mais adequado para regiões onde os rios são caudalosos e os lançamentos ocorrem em amplos intervalos, ao longo da bacia hidrográfica. Os padrões de qualidade quando trabalhados ao nível da comunidade, podem por ela ser tomados como essenciais e, assim motivar a sociedade para atingi-los.

Uma série de dificuldades que o sistema apresenta, relaciona-se com a indefinição dos níveis de tratamento necessários para as diversas fontes, para atender aos padrões de qualidade. Assim, no caso de fontes que descarregam os seus efluentes num mesmo corpo d'água, as de jusante teriam necessariamente que ter um grau de tratamento maior que uma de montante, dado o efeito acumulativo de um poluente. Em outros casos, fontes poluidoras, de um mesmo ramo de atividade, situadas em corpos d'água com diferentes capacidades de assimilação, demandariam graus de tratamento diferenciados, o que implicaria em custos unitários de produção também diferenciados, o que poderia até afetar a competividade no mercado considerado.

O segundo sistema, a partir do qual o controle é exercido, principia no ponto de descarga e se estende ao processo industrial ou à natureza da atividade geradora do efluente. A base do controle consiste no monitoramento do efluente, mas não se estabelece "a priori" um limite para os efluentes. A exigência de remoção de substâncias poluente deve ir até o ponto onde a tecnologia corrente permite.

A maior vantagem desse sistema é que a proteção da qualidade das águas seria a máxima possível e a melhoria da qualidade das águas poderia acompanhar as evoluções técnicas no tratamento de efluentes. Um ponto fraco dessa linha de 
controle quando tomada isoladamente é que não se leva em conta as diferenças na capacidade de assimilação dos corpos d'água, podendo esse fato resultar em investimentos desnecessários no tratamento de efluentes. Outro aspecto que pode ser considerado consiste em que a interpretação do termo "melhor tecnologia prática disponível" pode ser controvertida e, assim, levar a disputas legais.

$\mathrm{O}$ terceiro sistema requer que a concentração de poluentes no efluente não exceda valores determinados pela autoridade de controle, independentemente do local de descarga e da natureza da atividade geradora da poluição. Um avanço na linha de aperfeiçoamento desse sistema seria o estabelecimento dos padrões de emissão, levando-se em conta o potencial médio de poluição numa determinada região e também a eficiência das técnicas correntes de tratamento para remoção de poluentes.

A maior vantagem desse método consiste na sua simplicidade administrativa e no fácil entendimento da forma de controlar. Além disso, elimina ou reduz a oportunidade de evasão por parte dos responsáveis pela poluição. Deve-se observar que a sua aplicação impõe o mesmo custo unitário de tratamento de efluentes industrias de um mesmo ramo de atividade.

Todos esses tópicos estão inseridos na legislação ambiental do Estado de São Paulo, razão pela qual ela é um instrumento flexível na formulação de políticas regionais, onde, à luz da sua realidade, pode-se acentuar mais um ou outro desses sistemas de controle. No entanto, a aplicação conjunta de todos esses enfoques no âmbito de cada bacia hidrográfica, através de estratégias de controle, é conseguida pela formulação de uma política orientadora, tanto do corpo técnico da agência de controle, como da sociedade.

Conforme DERÍSIO (1992) todo e qualquer programa de controle da poluição das águas deve possuir um conjunto de diretrizes objetivas e claras as quais nortearão a política de controle a ser aplicada. Entre as diretrizes a serem estabelecidas podemse mencionar:

- aplicação de padrões de qualidade;

- sequenciamento de prioridades em função dos usos das coleções hidricas;

- flexibilidade e adaptabilidade dos padrões de qualidade; 
- aplicação de padrões de emissão;

- critérios de emissão;

- priorização de fontes de poluição;

- tratamento conjunto, desde que viável técnica e economicamente;

- controle preventivo;

- administração de prazos na implantação dos sistemas de tratamento;

- desenvolvimento de tecnologia no campo do tratamento de resíduos;

- integração e coordenação das atividades entre os órgãos públicos; e

- informação à comunidade.

\subsubsection{Fontes Pontuais}

As principais fontes localizadas de poluição da água superficial são os lançamentos de esgotos domésticos e industriais.

O planejamento do uso do solo pode contribuir para atenuar este problema disciplinando os locais para lançamento das águas residuárias provenientes da rede de esgotos domésticos ou das indústrias. A localização dos pontos de lançamento de efluentes de estações de tratamento, quando adequadamente escolhida, pode minimizar os efeitos da poluição sobre as atividades humanas nas cidades.

A definição de locais para lançamento de efluentes de estações de tratamento de esgoto depende de vários fatores:

- situação atual e desejada para os recursos hidrícos da bacia hidrográfica. Usos previstos para os mesmos;

- volume e características dos despejos (estimativa da carga poluidora);

- conhecimento dos parâmetros que, influem no processo de autodepuração da água: volume do corpo receptor; condições de escoamento; oxigênio dissolvido; poluentes existentes;

- posicionamento em relação à área urbanizada, ao local de captação da água para abastecimento e às outras comunidades.

Os recursos hídricos de uma bacia hidrográfica devem ser classificados em 
função dos usos a que se destinam. Devido à multiplicidade de aproveitamento da água e a existência de usos conflitantes para um mesmo manancial, é importante que seja feita, antes de tudo, uma classificação dos recursos, definindo usos preponderantes para as águas.(MOTA, 1981).

\subsubsection{Fontes Difusas}

As principais fontes não localizadas de poluição d'água são as águas de infiltração e as águas de escoamento superficial (runoff).

Uma medida de controle da poluição de mananciais superficiais de água com relação à percolação de líquidos poluídos no solo é o afastamento entre a fonte de poluição e a formação hídrica. A distância entre o foco poluidor e a água constitui uma barreira efetiva ao deslocamento de poluentes, especialmente compostos orgânicos e patogênicos.

Com relação às águas de escoamento superficial, são várias as providências a serem adotadas visando reduzir os seus efeitos:

- diminuição da quantidade da água de escoamento;

- interceptação do líquido em escoamento;

- adoção de medidas para controle da erosão do solo;

- melhoria da limpeza das vias públicas;

- adoção de faixa de preservação às margens dos recursos superficiais.

O volume do runoff é função de vários fatores: quantidade e intensidade das chuvas, declividade do terreno, tipo de vegetação existente, pavimentação do solo, características do terreno. Assim, algumas medidas de controle da erosão do solo são também válidas no sentido de evitar um grande volume de água de escoamento superficial:

- cobertura vegetal adequada;

- preservação do escoamento natural das águas;

- disciplinamento do uso do solo, principalmente em terrenos com grande 
declive.

Algumas vezes, é necessária a utilização de dispositivos para reter, temporária ou permanentemente, o líquido escoado. Estes podem constar de:

- construção de valetas ou diques para desvio das águas;

- execução de "bacias de sedimentação", para acumular a água durante certo tempo, reduzindo a quantidade de poluentes e controlando a velocidade do fluxo de escoamento;

- acumulação da água em reservatórios, podendo o líquido ser utilizado para usos recreacionais, paisagísticos, em irrigação, em combate a incêndios, etc.

As faixas de proteção constituem uma eficiente medida de preservação dos recursos hídricos superficiais. Quando adequadamente tratadas, formam uma efetiva barreira ao deslocamento de poluentes no solo, bem como áreas propícias à infiltração da água e conseqüente diminuição do volume do runoff.

As faixas de proteção são áreas situadas às margens de coleções de água, as quais são preservadas através de um disciplinamento rigoroso do uso do solo.

Obviamente, as faixas de proteção não constituem uma medida de eficiência total. Mesmo com a sua existência, líquidos escoando no subsolo ou superficialmente alcançarão as coleções de água, carreando poluentes. O solo funciona como elemento "purificador" da água, principalmente para compostos orgânicos e para patogênicos. Porém, muitos poluentes químicos conseguem percorrer grandes distâncias, invalidando as faixas de proteção, nestes casos.

No entanto, deve-se considerar muitas vantagens para as faixas. Além do aspecto de isolamento sanitário, as áreas preservadas às margens de coleções superficiais de água apresentam as seguintes utilidades:

- protegem áreas adjacentes da ocorrência de cheias;

- constituem medida de controle da erosão;

- proporcionam a preservação da vegetação existente, garantindo a proteção da fauna e flora típicas. As árvores, às margens de coleções de água, 
contribuem para o sombreamento e a conseqüente manutenção da temperatura adequada à fauna aquática;

- podem constituir áreas para recreação, ou de preservação paisagística e ecológica;

- asseguram o escoamento adequado das águas pluviais, garantindo a drenagem das mesmas.

Embora a faixa de proteção não elimine totalmente os poluentes, podemos dizer que ela atenua os seus efeitos sobre os recursos hídricos. Esta eficiência pode ainda ser maior se, além da faixa de proteção, for feito um disciplinamento do uso do solo nas áreas vizinhas à mesma.

Com o objetivo de preservar a vegetação, o Código Florestal Brasileiro - Lei $\mathrm{n}^{\circ}$ 4.771 (BRASIL 1965) - considera, pelo artigo 20, de preservação permanente as florestas e outras formas de vegetação natural situadas: ao longo dos rios ou qualquer curso d'água desde de seu nível mais alto em faixa marginal cuja largura mínima seja:

a) de $30 \mathrm{~m}$ para cursos d'água de menos de $10 \mathrm{~m}$ de largura;

b) de $50 \mathrm{~m}$ para cursos d'água que tenham de $10 \mathrm{~m}$ a $50 \mathrm{~m}$ de largura;

c) de $100 \mathrm{~m}$ para cursos d'água que tenham de $50 \mathrm{~m}$ a $200 \mathrm{~m}$ de largura;

d) de $200 \mathrm{~m}$ para cursos d'água que tenham de $200 \mathrm{~m}$ a $600 \mathrm{~m}$ de largura ao redor de lagoas, lagos ou reservatórios d'água naturais ou artificiais e num raio de $50 \mathrm{~m}$ de largura ao redor das nascentes de rios qualquer que seja sua situação topográfica; nos topos de morros, montes, montanhas e serras; nas encostas ou parte destas com declividade superior a $45^{\circ} \mathrm{em}$ altitude maior que $1.800 \mathrm{~m}$ para qualquer que seja a vegetação.

E pelo artigo 100 não é permitida a derrubada de florestas situadas em áreas de inclinação entre $25^{\circ}$ a $45^{\circ}$, só sendo nelas toleradas a extração de toras quando em regime de utilização racional que vise o rendimento permanente.

Estas faixas, mesmo visando preservar a vegetação, podem ser utilizadas como parte integrante de um planejamento visando a proteção sanitária dos recursos hídricos (MOTA 1981). 


\subsection{Geotecnologias}

Segundo LOAGUE e col. (1998), quando Sistemas de Informação Geográfica - SIG e modelos ambientais são associados, eles fornecem um eficiente meio de manusear a heterogeneidade espacial e temporal complexas da superfície da terra e da sub-superfície.

\subsubsection{Descrição Geral de SIG}

O termo "Sistemas de Informação Geográfica" (SIG) é aplicado para sistemas que realizam o tratamento computacional de dados geográficos e recuperam informações não apenas com base em suas características alfanuméricas, mas também através de sua localização espacial. Para que isto seja possível, a geometria e os atributos dos dados num SIG devem estar georreferenciados, isto é, localizados na superfície terrestre e representados numa projeção cartográfica.

$\mathrm{O}$ requisito de armazenar a geometria dos objetos geográficos e de seus atributos representa uma dualidade básica para SIG's. Para cada objeto geográfico, o SIG necessita armazenar seus atributos $\mathrm{e}$ as várias representações gráficas associadas. Devido a sua ampla gama de aplicações, segundo CÂMARA e col. (2001), há pelo menos três grandes maneiras de utilizar um SIG:

- como ferramenta para produção de mapas;

- como suporte para análise espacial de fenômenos;

- como um banco de dados geográficos, com funções de armazenamento e recuperação de informação espacial.

Estas três visões do SIG são antes convergentes que conflitantes e refletem a importância relativa do tratamento da informação geográfica dentro de uma instituição. 


\subsubsection{Organização de Trabalho em Ambiente SIG}

Num SIG, segundo CÂMARA e col. (2001) existem duas grandes formas de organização de um ambiente de trabalho:

- organização baseada num banco de dados geográficos;

- organização baseada em projetos.

No primeiro caso, o usuário define inicialmente o esquema conceitual associado às entidades do banco de dados geográficos, indicando para cada tipo de dados seus atributos não-espaciais e as representações geométricas associadas. Procede-se da mesma forma que num banco de dados tradicional (como o dBASE ou o ACCESS), onde a definição da estrutura do banco precede a entrada dos dados. No segundo caso, o usuário define inicialmente um referencial geográfico (que delimita uma região de trabalho) e a seguir, define as entidades geográficas que compõem o projeto. Note-se que um banco de dados geográficos no SPRING pode ser subdividido em projetos, sendo que as definições de um esquema conceitual valem para todos os projetos do banco, mesmo que não haja continuidade espacial entre estes projetos.

Conforme CÂMARA e col. (2001) "Um projeto é usualmente composto por um conjunto de níveis, camadas ou planos de informação (PI), que variam em número, tipos de formatos e de temas, conforme as necessidades de cada tarefa ou estudo. "Cita como exemplo um estudo hipotético de uso atual do solo e seus impactos sobre o ambiente em uma região definida em um projeto. Para tanto seria necessário que este projeto fosse composto de PI com os seguintes temas: 1) rede de drenagem; 2) cidades, rodovias e ferrovias; 3) altimetria; 4) geomorfologia; 5) unidades e associações dos solos; 6) tipologia vegetal; 7) tipos de uso e ocupação das terras. Os PI 1, 2 e 3, quando superpostos, vão formar a cartografia básica da região de estudo ou mapa topográfico. Os PI restantes são os mapas especiais ou temáticos necessários para atingir o objetivo proposto, isto é, cada PI representa uma mesma área, mas com informações geográficas diferentes. 
Os PI's de um projeto podem pertencer a diferentes classes de dados, relacionadas com os formatos de representação de dados disponíveis no SIG utilizado.

Esta organização da informação espacial é muito conveniente para permitir que diferentes variáveis sejam integradas ao banco de dados e que diferentes tipos de estudo possam ser realizados, combinando tão somente os fenômenos de interesse.

\subsubsection{Funcionalidade Básica}

Segundo CÂMARA e col. (2001) em geral, qualquer SIG é capaz de:

- representar graficamente informações de natureza espacial, associando a estes gráficos informações alfanuméricas tradicionais. Representar informações gráficas sob a forma de vetores (pontos, linhas e polígonos) e/ou matrizes (imagens, campos, etc);

- recuperar informações com base em critérios alfanuméricos, à semelhança de um sistema de gerenciamento de bancos de dados tradicional, e com base em relações espaciais topológicas, tais como continência, adjacência e interceptação;

- realizar operações de aritmética de polígonos, tais como união, interseção e diferença. Gerar polígonos paralelos (buffers) ao redor de elementos ponto, linha e polígono;

- limitar o acesso e controlar a entrada de dados através de um modelo de dados, previamente construído;

- oferecer recursos para a visualização dos dados geográficos na tela do computador;

- interagir com o usuário através de uma interface gráfica, geralmente amigável;

- recuperar de forma ágil as informações geográficas, com o uso de algoritmos de indexação espacial; 
- possibilitar a importação e exportação de dados de/para outros sistemas semelhantes, ou para outros softwares gráficos;

- oferecer recursos para a entrada e manutenção de dados, utilizando equipamentos como mouse, mesa digitalizadora e scanner;

- oferecer recursos para a composição de saídas e geração de resultados sob a forma de mapas, gráficos e tabelas, para uma variedade de dispositivos, como impressoras e plotter;

- oferecer recursos para o desenvolvimento de aplicativos específicos, de acordo com as necessidades do usuário, utilizando para isto alguma linguagem de programação, inclusive possibilitando a customização da interface do SIG com o usuário.

Todos estes recursos podem ser agrupados em categorias, para facilitar a comparação entre diferentes sistemas. Estas categorias básicas são: entrada de dados, gerenciamento de informações, recuperação de informações, manipulação e análise, e exibição e produção de saídas.

\subsubsection{Modelos de Poluição de Fontes Pontuais}

\section{Modelagem para Simulação de Qualidade da água em SIG}

ESCADA E SOUSA (2001) testaram a aplicação de um modelo dinâmico, o modelo de autodepuração de Streeter Phelps (TUCCI 1998, p. 556), em ambiente de SIG, utilizando o aplicativo do INPE - SPRING, num trecho da bacia do Rio Paraíba do Sul, situado entre a Barragem de Santa Branca e a divisa dos municípios de Jacareí com São José dos Campos.

A rede hidrográfica referente à área em estudo foi importada para o SPRING, onde foram identificados e posicionados os pontos de contribuição considerados significativos em termos de vazão e cargas poluidoras pontuais. A estes parâmetros foram acrescidos parâmetros de qualidade, DBO e OD, formando o conjunto de atributos de cada ponto de contribuição, que alimentaram os modelos adotados.

Para possibilitar a atualização dos dados de vazões e cargas contribuintes, um 
Plano de Informação Cadastral das sub-bacias, com atributos de precipitação e população foi gerado, conforme ilustrado na Figura 2, juntamente com imagem de satélite georreferenciada.

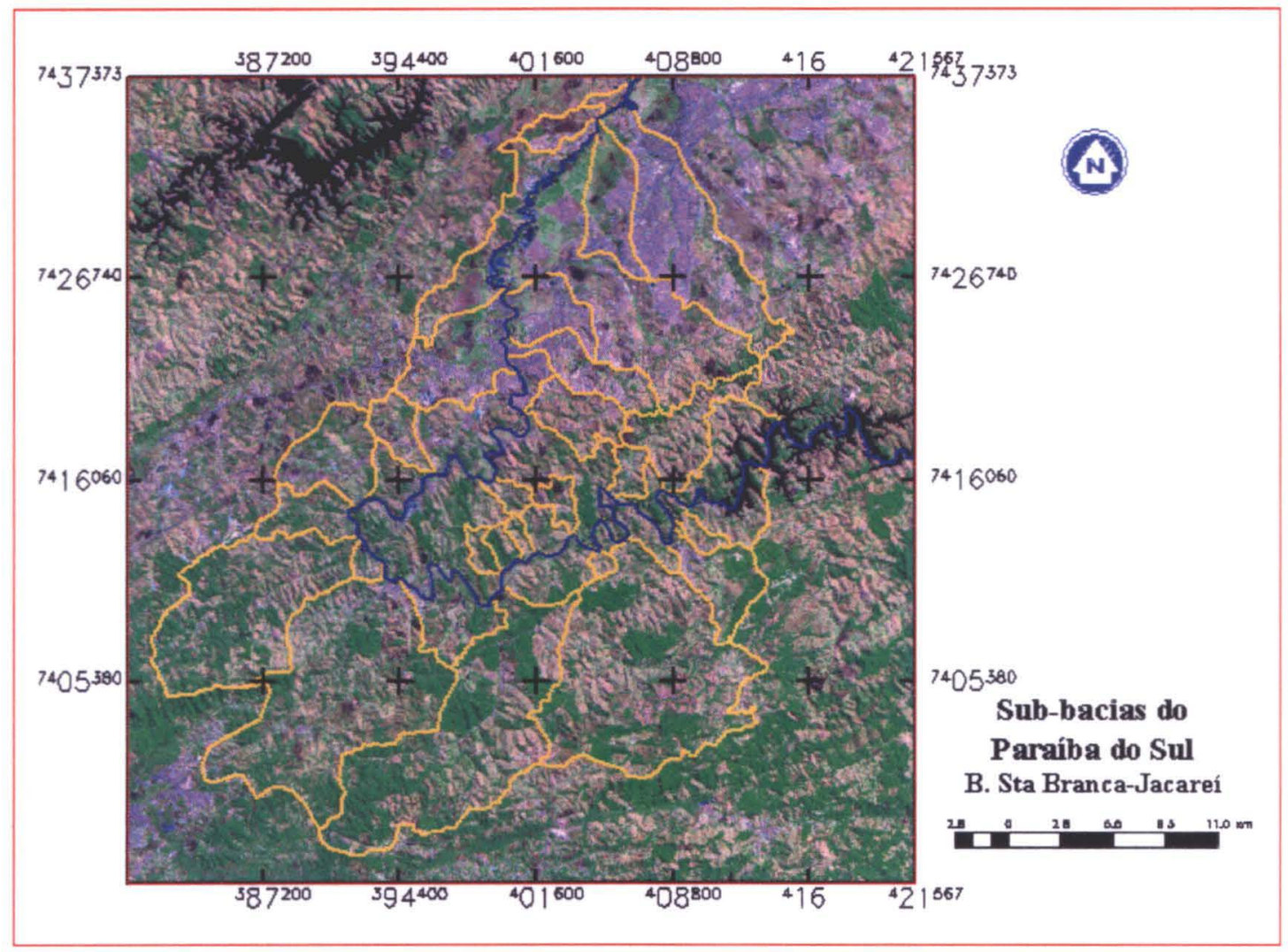

Figura 2 - Sub-bacias do Paraíba do Sul sobrepostas à Imagem de satélite - trecho Sta Branca - Jacareí. Fonte: ESCADA E SOUZA (2001)

A modelagem utilizada para representar a situação crítica de qualidade do corpo hídrico receptor, considerando o aporte de cargas pontuais, em ambiente de SIG, mostrou-se adequada.

Apesar das dificuldades que tiveram em face de abordagem em modelagem dinâmica exigir o uso de recursos de programação num nível mais avançado, concluiram que o uso de modelos em ambiente de SIG propicia resultados diferenciados em relação aos métodos convencionais, tal como a possibilidade de combinação com diversos mapas e dados, possibilitando ajustes e melhor compreensão dos fatores intervenientes na modelagem.

A utilização de softwares mais voltados para a modelagem dinâmica, como o PCRaster, representa uma perspectiva promissora. 
ZABADAL e col. (1999) desenvolveram o que entitularam de "Sistema Híbrido de Simulação de Poluentes", que é uma ferramenta desenvolvida para subsidiar o planejamento adequado de obras de saneamento, através de simulações de alternativas para o tratamento de esgotos em seus mais variados níveis, e também no planejamento de localizações de captações de água bruta. O modelo também é aplicado para ajustar o monitoramento de qualidade da água do Guaíba.

Os cenários analisados mostravam os impactos das chuvas sobre as águas do Guaíba e a melhoria decorrente da implantação da rede coletora de esgotos.

Conjugando programas de geoprocessamento (SIG), matemática aplicada, programação visual e sistemas de gerenciamento de banco de dados (SGBD), criou uma interface para usuários de diversos níveis, o que facilita a divulgação e $o$ entendimento do assunto tanto para um público leigo quanto para o técnico.

O sistema foi desenvolvido na linguagem Visual Basic 5 para Windows 95/NT e roda em micros $\mathrm{PC}$.

Os sistemas utilizados na simulação do processo de propagação de efluentes em rios baseiam-se, em geral, em métodos numéricos obtidos a partir de formulações em diferenças finitas ou em elementos finitos. O método ZABADAL e col. (1999) utiliza a transformada de Fourier na obtenção de soluções aproximadas para a equação bidimensional de dispersão, e o conceito de "marcha" das formulações numéricas TDT (Técnicas Dependentes do Tempo) para avaliar a evolução das soluções ao longo do tempo.

As vazões de interesse foram calculadas baseado no "Manual de Cálculo das Vazões Máximas, Médias e Mínimas nas Bacias Hidrográficas do Estudo de São Paulo" do Departamento de Águas e Águas e Energia Elétrica do Estado de São Paulo - DAEE (1994).

\subsubsection{Modelos de Poluição de Fontes Difusas}

A avaliação de poluentes não pontuais é um problema ambiental multidisciplinar complexo que envolve processos físicos e químicos associados, que ocorrem através de escalas espacial e temporal. 
As cargas difusas apresentam uma dinâmica complexa, segundo EIGER e col. (1998), com as seguintes particularidades:

- grande variabilidade, de uma sub-bacia para outra, e numa mesma sub-bacia em momentos diferentes, resultado da multiplicidade de fatores e fontes de poluição que agem de forma pouco previsível;

- afluem aos cursos de água tanto em tempo seco quanto na ocorrência de eventos de chuva;

- dependem das características das precipitações (intensidade e distribuição das chuvas), concentrando-se na fase inicial do evento de chuva em razão de efeito de lavagem (first flux) da bacia e das calhas de drenagem.

WPCF Research Foudation (1990) citado por EIGER e col. (1998, p. 6) agrupa os métodos básicos para a estimativa de cargas difusas em três, e em níveis crescentes de sofisticação:

- coeficientes de exportação ou cargas unitárias em $\mathrm{g} / \mathrm{ha}$ ou equivalentes: característicos de determinados tipos de uso do solo, têm sido utilizados em grande número de estudos e constitui procedimento aceitável quando o que se requer são estimativas de cargas para efeito de planejamento. Por construção, este método não permite descrever explicitamente a correlação das cargas difusas com a hidrologia da bacia, mas apresenta a vantagem de ter uma formulação matemática muito simples e ser facilmente utilizado;

- Concentração Média de Eventos de Chuva - CME: trata-se de um conceito amplamente adotado na literatura internacional, que representa a concentração média observada durante um evento de chuva. Análises estatísticas de um conjunto de eventos de chuva permitem obter CME características para determinados padrões de uso do solo ou tipos de bacias.As cargas correspondentes são calculadas multiplicando-se as CME pelos deflúvios (anuais ou sazonais);

- modelos de simulação conjunta de deflúvios de qualidade de água: teoricamente constituem o melhor método de representação, pois, em tese, 
permitem simular explicitamente os mecanismos de acumulação, arraste e transporte de poluentes da bacia para a foz do corpo d'água. São modelos complexos e requerem a disponibilidade de uma ampla base de dados, sendo mais indicados para estudo de bacias representativas.

Para a avaliação de áreas fontes críticas, um SIG oferece a oportunidade de integrar dados de hidrologia, topografia, solo e uso do solo em um único sistema.

Alguns estudos buscam avaliar os efeitos das práticas agrícolas na degradação dos recursos solo e águas subterrâneas e superficiais. Acredita-se que através do mundo, de 30 a $50 \%$ da superfície terrestre é afetada por fontes não pontuais de poluição (World Soil Erosion and Conservation 1993 citado por LOAGUE e col. 1998, p. 130 A).

KRONVANG e col. (1995) verificaram que na Dinamarca a carga fluvial de nitrogênio de fontes difusas oriundas de áreas de drenagem agrícolas, eram 14 vezes superiores aquelas que ocorrem em áreas isentas de ações antrópicas.

Este tipo de poluição ganha importância a medida que a sua ocorrência se dá em grandes áreas, apesar da concentração relativamente baixa em que se apresentam tais poluentes. Desta forma as ações de remediação se tornam difíceis, principalmente no aspecto referente ao custo, evidenciando a relevância de ações preventivas. Isto pode ser feito prevendo-se o caminhamento do poluente no solo de modo a evitar ocorrência potencial de condições danosas, tais como a contaminação das águas subterrâneas, antes que sérios impactos ocorram.

Muitas atividades que requerem considerações de uso do solo, vegetação, solo, topográfica e hidrológica podem ser descritas e modeladas usando SIG. Adicionalmente para a identificação e gerenciamento de fontes não pontuais, o SIG pode também ser utilizado no gerenciamento da qualidade da água, planejamento de uso do solo ou zoneamento, conservação do solo e proteção ambiental.

\subsubsection{Histórico}

O uso de SIG para a modelagem de cargas poluidoras inicia-se em meados da década de 80 e intensifica-se na década de 90, inicialmente como ferramenta para 
gerar dados de entrada em modelos, especialmente aqueles voltados para a área agrícola.

SIVERTUN e col. (1988) avaliaram na Suécia, que a conservação do solo e a proteção da qualidade da água podem ser alcançadas simultaneamente, excluindo-se da produção agrícola os terrenos considerados como críticos em sua análise.

Em relação às fontes de poluição não pontuais, a análise das áreas críticas inclue (1) investigações do local e reconhecimento do uso do solo, (2) sobreposição de mapas (manual ou computadorizada) e (3) modelagem de poluente de campo.

O uso de sobreposição de mapa (originalmente através de mesa de luz) para identificar áreas singulares foi popularizado por McHarg, 1969 (SIVERTUN e col. 1988). Houve um rápido desenvolvimento nos métodos conceituais para análises espaciais e aumento das possibilidades para mapeamentos temáticos quantitativos e análises espaciais (BURROUGH, 1998). Essas melhorias formalizadas pelo SIG têm levado a um maior uso de sobreposição de mapas computadorizados para avaliar erosão e potencial poluidor de fontes não pontuais. Thornton e Ford sugeriram em 1985 o uso de sobreposição transparente ou mapas digitalizados de inclinação, vegetação e potencial para erosão do solo para determinar áreas contribuintes críticas de fontes não pontuais. Helldén em 1987 usou a Equação Universal de Perda de Solo (Universal Soil Loss Equation - USLE) para estimar a erosão do solo no intuito de avaliar a necessidade de medidas de conservação do solo.

Os métodos mais detalhados de identificar áreas críticas envolvem o uso de modelos de poluentes do campo. HORNER e col. (1986) classificaram estes modelos em três categorias baseadas em sua estrutura, proposta e sofisticação; (1) modelo de poluente de campo simples, (2) modelos funcionais de carga empírica e (3) modelos de simulação matemática.

SIG podem ser utilizados para realizar estudos qualitativos ou quantitativos, ou ambos, dependendo da necessidade de informação e dados. Um SIG é particularmente útil para casos onde a resolução geométrica e a informação relativa à distribuição espacial são importantes. No caso específico para a aplicação que fizeram, o ganho de um estudo prévio foi uma mudança na resolução das células de $5000 \times 5000 \mathrm{~m}$ para $50 \times 50 \mathrm{~m}$. A economia de tempo e custos, usando um sistema 
SIG comparado com outros métodos, tornou possível empreender investigações mais minuciosas.

O estudo de SIVERTUN e col. (1988) é focado na seleção de áreas críticas para problemas de qualidade da água relacionados a sedimentos e à proteção dos recursos do solo. O modelo disponível para este tipo de estudo é o USLE. De acordo com o USLE utilizamos quatro mapas de fatores, digitalizados para a determinação de áreas críticas não pontuais (1), mapa de solo (2) mapa de inclinação, (3) mapa de uso do solo e (4) mapa do curso d'água. O mapa do curso d'água é uma síntese de dois fatores USLE (a) densidade de rio e (b) proximidade da superfície d'água.

Classificações foram feitas para tipo de solo, inclinação, uso do solo e distância do curso d'água. Os quatros mapas foram sobrepostos para identificar áreas potencialmente críticas e sub-críticas. Esta informação pode então, após a verificação pelo modelo de transporte de sedimento local, ser usada para ajudar no desenvolvimento de estratégias de controle de fontes não pontuais ou para elaborar programas de monitoramento.

Al-Abed and Whiteley (1995) citados por MAIDMENT e SAUNDERS (1996, p. 10) utilizaram um SIG para simular os efeitos de mudanças no uso do solo e estratégias de gerenciamento de recursos na qualidade e quantidade de água de irrigação na porção baixa da bacia do Grand River, no sudeste de Ontario, Canadá. Utilizaram o programa Arc/Info para estabelecer segmentos de bacia baseado na classificação do solo e tipo de uso do solo/cultivo. Para cada segmento de bacia, a capacidade de retenção de água, a capacidade de infiltração no solo, a inclinação da superfície, e a armazenagem inicial de água no solo foram calculadas e fornecidas como entrada para o modelo Hydrological Simulation Program-FORTRAN - HSPF da Environmental Protection Agency - EPA.

Zhang e col. (1995), citados por MAIDMENT e SAUNDERS (1996, p. 12), utilizaram o modelo Chemicals, Runoff, and Erosion from Agricultural Management Systems - CREAMS, desenvolvido pelo U.S. Department of Agriculture-Agricultural Research Service para auxiliar na avaliação da melhor prática de manejo agrícola para o controle de poluição, numa versão modificada voltada para simular o runoff e nutrientes sob condições de alto índice de água, junto com QUAL2E e o Lake Okeechobee Agricultural Descision Support System-LOADSS baseado em SIG, para 
simular os processos de transporte de fósforo nas bacias que drenam para o Lake Okeechobee no sul da Florida. O LOADSS foi utilizado para fornecer dados de uso do solo distribuídos espacialmente para o modelo CREAMS-WT calcular valores de concentração de fósforo através da bacia. Este dado juntamente como o dado de runoff é então fornecido ao QUAL2E, o qual simula o transporte e retenção de fósforo em várzea e canais de drenagem.

O Agicultural Nonpoint Source Pollution Model-AGPNS foi criado pelo U.S. Department of Agriculture-Agricultural Research Service para comparar os efeitos de diferentes práticas gerenciais de controle de poluição de bacias. Ele simula as cargas de sedimentos e nutrientes de bacias para eventos singulares de tempestades ou para dados de entrada contínuos. O AGPNS é dividido em dois sub-modelos. A parte de erosão do modelo fornece estimativa de erosão do planalto (terras altas), erosão do canal e fornecimento de sedimentos. O modelo utiliza a Equação Universal de Perda de Solo modificada (MUSLE) para cálculos de erosão do solo. A parte de transporte de poluentes do AGNPS é subdividido em uma parte que trata de poluentes solúveis e uma parte que lida com poluentes adsorvidos em sólidos. Cargas de Nitrogênio e Fósforo são determinadas utilizando relações entre concentrações químicas, produção de sedimento e volume de runoff. O AGNPS tem-se mostrado um modelo bastante popular entre os pesquisadores e existe um número significativo de estudos unindo o AGNPS a outros modelos e SIG (tais como: Geographic Resources Analysis Support System-GRASS e Arc/Info, por exemplo).

O modelo Areal Nonpoint Source Watershed Environment Response Simulation-ANSWERS foi desenvolvido pelo Agricultural Engineering Department of Purdue University na década de 60. Ele é um modelo de parâmetro distribuído, baseado em eventos para prever resposta hidrológica e erosão de bacias agrícolas. A abordagem por parâmetros distribuídos permite ao usuário levar em consideração a variabilidade espacial das variáveis de entrada.

O Soil Water and Assessment Tool-SWAT desenvolvido no Texas Water Resource Institute no College Station, Texas por Arnold e col. (1993), conforme citado em MAIDMENT e SAUNDERS (1996, p. 15), é um modelo de bacia distribuído espacialmente contínuo operando em passos de tempo diário. Ele simula o runoff, movimento de sedimento, nutrientes e pesticidas através da bacia e auxilia 
na avaliação do fornecimento de água e de fontes de poluição não pontuais em grandes bacias.

TIM AND JOLY (1994), classificam a integração de SIG com modelos de qualidade da água/hidrológicos em três níveis. No primeiro nível de integração, conhecido como Ad-hoc, o SIG e o modelo são desenvolvidos separadamente e são executados independentemente. O SIG serve apenas como pré-processador dos dados de entrada do modelo, sendo que a maioria dos modelos citados até então se enquadram nesta categoria.

O segundo nível de integração - integração parcial - é o resultado do estabelecimento de uma interface interativa entre o SIG e o modelo. Neste nível de integração, o SIG fornece dados de entrada para o modelo, mas também aceita resultados do modelo para processamento posterior ou apresentações.

No terceiro nível de integração, referendado como integração completa ou modelo dentro do SIG, a funcionalidade do modelo de qualidade da água/hidrológico é implementada ou programada diretamente dentro do SIG, de tal forma que o préprocessamento de dados e as funções analíticas são realizadas pelo mesmo sistema operacional. Este tipo de integração é tecnicamente a preferida dos modeladores, mas freqüentemente de difícil implementação, devido às incompatibilidades nas estruturas de dados do modelo e o SIG, ou devido aos direitos de propriedades do software SIG comerciais, limitando a introdução de rotinas de processamento adicionais.

EIGER e col. (1998) utilizaram um método baseado na Concentração Média de Eventos de Chuva - CME para estimar a carga de fósforo, de origem difusa, em 7 bacias-piloto afluentes a represa do Guarapiranga em São Paulo, com áreas e ocupações distintas. Com auxílio de modelo matemático, base de estudos de Huber (1986) com cargas difusas, verificaram que as cargas difusas podem ser caracterizadas por uma concentração média constante de poluente, permitindo a previsão destas cargas para eventos de qualquer duração. 


\subsubsection{Proteção através de Faixas de Preservação}

Uma das técnicas de controle de fontes de poluição não pontuais (NPS - nonpoint source) é a de estabelecer faixas vegetais de proteção (buffer) junto às margens da costa ou rio. Estas faixas de proteção funcionam como filtros para retardar, absorver ou purificar o escoamento superficial contaminado antes deste alcançar os corpos d'águas.

O estabelecimento de faixas vegetais de proteção é um importante componente das melhores práticas de gerenciamento da qualidade $\mathrm{d}$ água.

Entretanto, padrões para a largura da faixa de proteção são usualmente estabelecidos como regra prática que não são capazes de refletir variações regionais nas condições físicas. Isto se deve em parte à falta de um método cientificamente justificável de aplicação genérica. Os modelos científicos existentes são elegantes, mas usualmente de uma intensidade de dados e onerosos computacionalmente, limitando sua aplicabilidade.

O método desenvolvido por XIANG (1993), em ambiente de SIG fornece uma solução promissora. Ele integra um modelo cientificamente testado de delinear larguras de faixas de preservação variáveis num ambiente SIG. Técnica de carregar gerenciadores de banco de dados e de computação são manipuladas por SIG. A técnica pode ser integrada ao sistema de planejamento para dar suporte à tomada de decisões de uso do solo e ambientais.

O modelo para delinear buffer de largura variável utilizado por XIANG (1993), é derivado de um modelo de tempo de detenção de poluição. A base do modelo é uma equação para delinear a largura do buffer de reparo a qual avalia a eficiência relativa da zona do buffer em remover poluentes quando da passagem do escoamento por este, em termos da característica hidrológica, do solo, da cobertura do solo e da topografia. A equação é dada por:

$$
\mathrm{L}_{\mathrm{p}}=\mathrm{p}^{0,6} \mathrm{~L}_{\mathrm{r}}\left[\left(\mathrm{n}_{\mathrm{r}} / \mathrm{n}_{\mathrm{b}}\right)^{0,6}\left(\mathrm{~K}_{\mathrm{r}} / \mathrm{K}_{\mathrm{b}}\right)^{0,4}\left(\mathrm{~s}_{\mathrm{r}} / \mathrm{s}_{\mathrm{b}}\right)^{-0,7}\left(\mathrm{C}_{\mathrm{r}} / \mathrm{C}_{\mathrm{b}}\right)\right]
$$

Onde, os índices b e $\mathrm{r}$ referem-se respectivamente ao buffer proposto e ao buffer de referência; e: 
p - taxa de eficiência do buffer;

$\mathrm{n}$ - coeficiente de rugosidade de Manning (função da cobertura do solo e das condições da superfície);

L - é a largura do buffer [pés ou metro];

$\mathrm{K}$ - condutividade hidráulica de saturação [polegadas/hora ou centímetro/hora], equivalente a permeabilidade;

s - inclinação [\%];

C - capacidade de armazenamento de umidade do solo [polegadas ou centímetros];

Um banco de dados deve ser desenvolvido contendo dados do solo, topografia e características hidrológicas. Para o cálculo da inclinação linhas de contorno do mapa topográfico são introduzidas no banco de dados do SIG através de digitalização e formando um novo Plano de Informação (PI) (ou layer). Usando um procedimento de conversão do SIG este layer é convertido em uma malha triangular ou TIN (do inglês "triangular irregular network"), que depois é convertido em um layer de inclinação em porcentagem.

Cria-se com funções do SIG dois layers do solo e da inclinação. Apenas as unidades de mapa que se encontram dentro da faixa reduzida $(805 \mathrm{~m})$ é que serão armazenados no layer modificado.

Para calcular a largura do buffer sobrepõem-se os layers que contém os valores de $\mathrm{C}, \mathrm{K}$ e s, criando-se um novo layer.

Uma vez que o processo de sobreposição foi terminado cada parcela do mapa possui os valores de $\mathrm{C}, \mathrm{K}$ e s. Daí o modelo é implementado através de uma função no SIG para calcular a largura do buffer. Os parâmetros " $n$ " e " $p$ " são constantes e podem ser incorporados diretamente na fórmula.

SIQUEIRA (2000) desenvolveu metodologia baseada em técnicas de Sensoriamento Remoto (SR) e processamento de dados cartográficos com Sistema de Informação Geográfica (SIG) para a avaliar o grau de concordância da cobertura da terra em relação a critérios de preservação previstos no Código Florestal (BRASIL 1965). 
Os dados de SR possibilitaram a SIQUEIRA (2000) o mapeamento de áreas florestadas e não florestadas, enquanto que o SIG permitiu a análise de dados cartográficos para a identificação de áreas protegidas e a integração e análise de tais informações dentro de um contexto geográfico. Tendo como base o Código Florestal, foram identificadas e analisadas as áreas protegidas por lei passíveis de serem identificadas com recursos disponíveis no SPRING.

VENDRAME e col. (2003) associa o uso do solo, especialmente em áreas de preservação, com impactos na qualidade da água: assoreamento em áreas de solo exposto, principalmente próximos às nascentes e rios de primeira ordem, além de pastagens que, em menor grau, também proporcionam o assoreamento.

\subsubsection{Correlação entre o uso do solo e a qualidade das águas}

Dentre os sistemas/modelos pesquisados destacam-se a seguir aqueles que mais contribuíram para o desenvolvimento desta pesquisa:

HALLET e col. (1996) apresentam um sistema nacional (UK) de informação sobre o solo (LandIS), inicialmente (1979) criado para satisfazer a demanda de produtividade agrícola, mas que com os impactos ambientais da modernização da atividade agrícola, tais como poluição por nitrato e fosfato, percolação de pesticidas e contaminantes, deposição de metais pesados, erosão do solo e disposição de resíduos rurais, incorporou conceitos de modelos sustentáveis, tais como:

- poluição: nitratos, pesticidas e metais pesados;

- acidificação;

- disposição de resíduos rurais e de lodo de esgoto;

- erosão do solo: vento e água;

- vulnerabilidade das águas superficiais e do aqǘfero

- encolhimento afundamento do solo - inchamento e elevação;

- risco de corrosão à estrutura subterrânea.

Dentre as aplicações baseadas no banco de dados LandIS destaca-se o CatchIS que incluem os modelos denominados "SWAT" (Surface Water Attenuation Model) 
e "AQUAT" (Aquifer Attenuation Model), que buscam predizer a percolação e o runoff superficial, respectivamente, de pesticidas aplicados.

BERKA e col. (1995) utilizaram SIG como ferramenta para a análise da correlação entre o uso do solo e a qualidade da água.

Realizaram estudo de caso em três bacias hidrográficas do Lower Fraser Valley no Canadá, uma altamente urbanizada - a do Brunette River, outra mista: urbano rural e agrícola - a do Salmom River e uma intensivamente agrícola - a do Sumas River.

Para os três casos utilizaram os mesmos conceitos básicos para estudar os impactos do uso do solo na qualidade da água:

- a bacia como unidade de estudo,

- indicadores específicos como medida das características de uso do solo e da qualidade da água, e

- um Sistema de Informação Geográfica (SIG) como ferramenta de análise.

Um tipo de índice de uso do solo é a porcentagem de área de determinado uso do solo, ou a porcentagem de mudança na área de um tipo de uso para outro entre períodos de tempo.A intensidade da atividade é também uma característica vital de uso do solo. A densidade de criação, densidade de sistema séptico, densidade de tráfego, ou proporção de superfície impermeável podem representar a dinâmica particular de uma área. Estes por sua vez podem ser relacionados com a condição ou com a mudança na qualidade da água, que é representada por indicadores.

Os indicadores de qualidade da água são escolhidos com base no tipo de uso do solo evidente numa bacia, sendo que pode incluir ambos, as águas superficiais e a química dos sedimentos do leito do rio. Nitrato, coliformes fecais, ortofosfatos, cloretos, amônia e carbono total dissolvido ocorrem naturalmente em ambientes aquáticos. Porém, concentrações acima de níveis da base natural são freqüentemente indicativos da atividade humana. Oxigênio dissolvido, condutividade, $\mathrm{pH}$ e temperatura fornecem informações suplementares sobre a qualidade da água e das condições de vida para a biota aquática. 
Mudanças na qualidade da água podem estar associadas a dois tipos de escala temporal: mudanças de longo termo ou mudanças sazonais amostradas num ciclo anual.

Os sedimentos do leito dos rios são analisados para traço de metais comumentes conhecidos como sendo enriquecidos como resultado das atividades humanas. Fontes de metais, tais como cobre, cádmio, cromo, níquel, chumbo, mercúrio e zinco, incluem o transporte, indústria, corrosão de canos da água, fertilizantes e suplementos alimentares. Traços de metais são geralmente ligados nos sedimentos. Entretanto, quando certas condições existem, traços de metais podem intercambiar entre a coluna de água e os sedimentos, e podem também ser consumidos pelos organismos que filtram sedimentos.

As informações de uso do solo das bacias disponíveis são compiladas numa base de dados SIG, que utiliza dados topográficos como mapa de base, dados de censo, resultados de outros levantamentos que sejam geograficamente referenciados, fotografias aéreas, mapas de solo, outorgas de água e de descarga, mapas históricos de uso do solo, e inventários de peixes e fauna.

BERKA e col. (1995) aponta que esta parte do estudo é bastante trabalhosa e requer o conhecimento no uso de SIG para evitar erros envolvendo escala, combinação de mapas, digitalização, e gerenciamento de banco de dados. Aponta também as funcionalidades dos SIG para este tipo de estudo. A função de sobreposição no SIG pode ser utilizada para combinar dados, tais como mapa de densidade de acúmulo de solo e mapas de solo, para entender como e onde estas características podem se comportar conjuntamente. Zonas de amortecimento (buffer), paralelas aos canais de drenagem, podem ser geradas de tal forma que o uso do solo diretamente adjacente à corrente possa ser relacionado à qualidade da água. A área total contribuinte à montante do ponto de amostragem pode também ser relacionada à qualidade da água naquele ponto.

A bacia do Sumas River, área de tradição agrícola, apresentava recente intensificação na criação de porcos e aves (37.000 porcos e 4350.000 aves), superando a densidade máxima permitida em paises europeus que é de 2,4 a 2,8 unidades de criação por há, que visa manter a aplicação de esterco dentro da capacidade usual de absorção do solo e reduzir o risco de contaminação. A 
concentração de Nitrato alcança $7 \mathrm{mg} / 1$ durante os meses de verão (seca), possivelmente influenciado pela recarga subterrânea contaminada por práticas agrícolas. Níveis de Coliformes fecais e de ortofosfato na corrente principal são bem altos no inverno, devido ao runoff superficial. Portanto cargas excessivas de nutrientes oriundas de dejetos animais e fertilizantes tem afetado a qualidade da água nesta área de agronegócios.

A bacia do Salmon River, de 8020 há e habitada por 16.000 habitantes, apresenta uma intensificação nas atividades agrícola e residencial, em especial fazendas para hobby. Todas as residências da bacia são servidas por sistemas sépticos, e os resíduos de animais são comumentes aplicados aos campos. Levantamento em poços de abastecimento de água subterrânea confirmam concentrações de Nitrato acima do nível de base ( $3 \mathrm{mg} / 1)$ através do aqüífero; alguns poços apresentam concentrações acima do padrão de água potável do Canadá de 10 $\mathrm{mg} / \mathrm{l}$.

$\mathrm{Na}$ bacia do Brunette, onde reside mais de 160.000 habitantes em 7.200 hectares (dentro de Vancouver, Burnaby, New Westminster, Coquitlam, e Port Moody), o foco está na relação entre o uso do solo e a qualidade das águas pluviais e a resultante saúde ecológica das drenagens da bacia. Para tanto são realizadas avaliações de traço de metais $(\mathrm{Pb}, \mathrm{Cu}, \mathrm{Zn}, \mathrm{Cd}, \mathrm{Ni}, \mathrm{Cr}, \mathrm{Mn}$, and $\mathrm{Hg})$ e de contaminação por hidrocarbonetos nas águas pluviais, sujeira das ruas, sedimentos de corpos d'água, água de lagos. Hidrocarbonetos são monitorados visando isolar os efeitos do trafego em corpos d'água urbanos. Traços de metais estão relacionados ao uso de automóveis.

As atividades no solo, a permeabilidade do solo, e a densidade do trafego compõem os índices utilizados para medir as mudanças nos usos do solo.

SKOP E SORENSEN (1998) buscaram relacionar as mudanças na estrutura de produção agrícola ocorridas na Dinamarca com as alterações na qualidade das águas na bacia do Vejle Fjord, expressas principalmente pela sua eutrofização. A carga fluvial de nitrogênio incrementada com a transformação do setor agrícola dinamarquês é colocada como a principal causa. 
A bacia do Vejle Fjord situa-se na parte oriental da Dinamarca e possui 736 $\mathrm{km}^{2}$. A criação de animais predomina em sub-bacias arenosas, enquanto a produção agrícola predomina em sub bacias com solos argilosos, devido a sua fertilidade.

Foram levantadas as principais fontes de contribuições para as cargas de nitrogênio, sendo que dentre as cargas difusas a predominância vem do uso agrícola e dentre as fontes pontuais os sistemas de tratamento de esgotos predominam.

Para cada sub-bacia foram delimitadas as áreas contribuintes para as correntes superficiais e subterrâneas, que em alguns casos apresentavam limites significativamente distintos.

O transporte de Nitrogênio foi calculado para a saída de todas as sub bacias, como a soma das fontes pontuais e não pontuais, subtraindo-se aquelas retidas em lagos.

Para as fontes pontuais as informações foram extraídas de análise de amostragens realizadas periodicamente (indústrias e descargas de esgoto) e de dados de consumo de matéria prima e de produto final (piscicultura).

As contribuições das fontes não pontuais foram calculadas basicamente a partir das cargas de nitrogênio oriundas da agricultura e do solo, com base na fração de Nitrogênio lixiviado não removida, e que alcança então as correntes de água a jusante.

A partir da experiência Dinamarquesa adotou-se o valor de $5 \mathrm{~kg} /$ há.ano para o nitrogênio lixiviado de origem do solo.

Definiu-se um fator de probabilidade para mólecula de $\mathrm{NO}_{3}$ ser removida enquanto ela se desloca em uma unidade comprimento. A remoção ocorre quando a molécula de nitrato encontra uma zona anóxica durante uma unidade de comprimento de deslocamento. A variabilidade espacial onde a denitrificação ocorre origina o decaimento a ser expresso como função da distância com diferentes constantes de probabilidade de acordo com o caminho do escoamento.

Com base em correlação entre o tipo do solo e o caminho do escoamento estabelecida por Skop e Loaciga (1998) citado por SKOP e SORENSEN (1998, p. 296), a lixiviação do nitrogênio se dá no escoamento superficial e no de base. De acordo com estes $41 \%$ da lixiviação em solos argilosos foi transportada por escoamento superficial e $59 \%$ transportado por escoamento de base, enquanto em 
solos arenosos $10 \%$ foi transportado por escoamento superficial e $90 \%$ por escoamento de base.

Os fatores de probabilidade de remoção de nitrogênio $\left(\mathrm{m}^{-1}\right)$ foram determinados obtendo-se os resultados de 0,0 para o escoamento superficial e $0,00085 \mathrm{~m}^{-1}$ para o escoamento de base, o que implica que a remoção de nitrato no escoamento superficial é igual a zero.

A retenção em lago é calculada como o fluxo de entrada menos o de saída (medida da descarga). O decaimento no fluxo, que é dificil de modelar, é de menor importância comparado com a carga total para as condições dinamarquesas, e é então desprezada.

Dois grids de distância de escoamento foram calculados. Um grid é calculado como a distância de caminhamento de $\mathrm{N}$ de cada pixel até o curso d'água mais próximo seguindo a direção de escoamento da topografia e um segundo é calculado seguindo a direção de escoamento dos gradientes do nível de água subterrânea.

A carga de nitrogênio por pixel é calculada por ambas as lixiviação de nitrogênio de escoamento superficial e de base a menos da remoção de $\mathrm{N}$ ao longo de seu trajeto, para o curso d'água dividida pela lixiviação de $\mathrm{N}$.

A descarga de nitrogênio no escoamento superficial na saída das sub-bacias é calculada pela adição de todos os pixel de dentro de cada sub-bacia topográfica. Isto é feito sobrepondo-se o grid topográfico das sub bacias com o grid de carga de nitrogênio para escoamento superficial

A lixiviação do nitrogênio por hectare é maior em solo arenoso. A produção de biomassa e conseqüentemente de retirada de nitrogênio com a colheita é menor em solo arenoso, do que em argiloso. Uma vez que a quantidade de fertilizante, à base de nitrogênio, aplicado em solos arenoso e argiloso não leva em conta as diferentes retiradas de nitrogênio, é de se esperar que os residuais nos dois tipos de solos, posteriores a colheita, apresentem diferenças. O maior conteúdo de nitrogênio inorgânico na zona de raiz em solos arenosos é um dos fatores que explica as diferentes lixiviações de nitrato nos dois tipos de solos.

Parece ser razoável a concordância entre as cargas de nitrogênio medida e calculada, embora discrepâncias ocorram na faixa de 16 a 17\%. 
WANG E YIN (1997) procuraram estabelecer a condutividade eletrolítica como um indicador geral da qualidade da água, associando-o ao uso e ocupação do solo. Para tanto avaliaram o grau de correlação entre a condutividade e diversos parâmetros de qualidade de água analisados em seis estações de monitoramento instaladas ao longo do Great Miami River, e associou-as a uma parcela de influência da área de drenagem da bacia do referido rio.

A área de drenagem da bacia em estudo possui $9700 \mathrm{~km}^{2}$, por onde corta 0 Great Miami River numa extensão de $100 \mathrm{~km}$, apresentando mais de $80 \%$ de uso do solo agrícola e $16 \%$ de área urbana.

Apesar de 60 dos 199 parâmetros avaliados apresentarem correlação significativa com a condutividade, o uso desta como indicador de fonte de poluição de origem difusa não foi considerado satisfatório, uma vez que os parâmetros indicativos deste tipo de fonte não apresentavam forte correlação.

Para a avaliação de uso do solo, elevação e qualidade da água foram utilizados diferentes fontes em diferentes formatos.

A qualidade da água medida pela condutividade era fortemente relacionada com a parcela de uso do solo urbano, avaliada para a área de influência de cada uma das estações de monitoramento.

Para o caso específico de estudo de eutrofização de reservatórios o parâmetro fósforo pode vir a ser o fator limitante, e uma vez que no estudo WANG E YIN (1997) foi estabelecida uma correlação satisfatória com a condutividade, este parâmetro pode vir a ser um bom indicativo de fontes de poluição difusa, desde que às de origem urbana não preponderem.

MAIDMENT e SAUNDERS (1996) desenvolveram um método em Sistema de Informação Geográfica (SIG) para avaliar a poluição de origem não pontual em bacias hidrográficas. Este método utiliza dados públicos disponíveis de elevação, rede de drenagem, precipitação, descarga e uso do solo e utiliza uma discretização digital ou representação em grid de uma bacia para a aproximação de cargas médias anuais de poluentes e concentrações.

A metodologia desenvolvida foi aplicada na bacia de San Antonio-Nueces Coastal de aproximadamente $700 \mathrm{Km}^{2}$, situada no sul do Texas ao norte da cidade de Corpus Christi, envolve: 
- criação de Grid digital, réplica da rede de drenagem (esc 1:100.000) da bacia (escala 1:250.000), fixando a rede de drenagem a um modelo de elevação digital (malha de 1 há, a partir de mapas em escala que variam de $1: 24000$ a 1:250000),

- estabelecida relação matemática entre precipitação e o runoff, usando análise de regressão com os dados históricos (30 anos) de precipitação e de descarga de 5 postos fluviométricos,

- é criado um grid de distribuição espacial da carga média anual de poluentes, através somatório à jusante do produto da Concentração Média Esperada EMC (Expected Mean Concentration) de constituintes poluentes, espacialmente distribuídos em função do uso do solo da bacia (arquivos na escala 1:250000), pelo runoff.

\section{Refinamento da Metodologia:}

Para ajustar os valores de EMC para fósforo, foi utilizada uma rotina otimizada com dados de poluentes medidos em quatro pontos de amostragem e uma metodologia de simular fontes de poluição pontuais suspeitas é investigada.

A bacia que possui dois rios principais, desaguando na Copano Bay, é largamente rural, havendo apenas poucos municípios com população variando entre 3000 e 13500 habitantes aproximadamente, totalizando 52107 habitantes.

As maiores culturas e usos do solo que recebem a aplicação de nutrientes e produtos químicos incluem algodão, milho, grãos de sorgo, melão e pasto. $\mathrm{O}$ solo que suporta estes usos varia de argila Vitória calcária escura na porção costeira a marga arenosa fina no interior. Na parte superior à oeste a superfície apresenta marga pedregulhenta da série Olmos.

Foi empregada o Anderson Land Use Classification System para classificação de uso do solo a qual identifica sub categorias de dois dígitos dentro das categorias: urbana (residencial, comercial, industrial, de transporte, mista e outros), agrícola, campo, floresta, água, pântano (várzea), terreno estéril, tundra e gelo. Para o cálculo da carga de poluentes foram utilizados valores de Concentração Média Esperada (EMC) de 18 poluentes utilizados em trabalho anterior ao de MAIDMENT e 
SAUNDERS (1996) na baia de Corpus Christi, associadas ao uso do solo, conforme apresentado na tabela 1 a seguir:

Tabela 1 - Relação entre uso do solo e concentração esperada de poluentes

\begin{tabular}{|c|c|c|c|c|c|c|c|c|}
\hline Constituent & $\begin{array}{c}\text { Urban } \\
\text { Res } \\
11\end{array}$ & $\begin{array}{c}\text { Uhan } \\
\text { Commn } \\
12\end{array}$ & $\begin{array}{c}\text { Urban } \\
\text { Ind } \\
13\end{array}$ & $\begin{array}{c}\text { Urtan } \\
\text { Trans } \\
14\end{array}$ & $\begin{array}{l}\text { Urban } \\
\text { Mixed } \\
16,17 \#\end{array}$ & $\begin{array}{l}\text { Agr } \\
2^{*}\end{array}$ & Range & $\begin{array}{c}\text { Undew } \\
\text { Open } \\
7^{*}\end{array}$ \\
\hline Total Nitrogen $(\mathrm{mg} / \mathrm{L})$ & 1.82 & 1.34 & 1.26 & 1.86 & 1.57 & 4.4 & 0.7 & 1.5 \\
\hline Total Kjeldahi N. (mg/L) & 1.5 & 1.1 & 1 & 1.5 & 1.25 & 1.7 & 0.2 & 0.96 \\
\hline Nitrate + Nitrite (mgh as N) & 0.23 & 0.26 & 0.3 & 0.56 & 0.34 & 1.6 & 0.4 & 0.54 \\
\hline Total Phosphorus (mgly) & 0.57 & 0.32 & 0.28 & 0.22 & 0.35 & 1.3 & $<0.01$ & 0.12 \\
\hline Dissolved Phos (mg/L) & 0.48 & 0.11 & 0.22 & 0.1 & 0.23 & & & 0.03 \\
\hline Suspended Solids (mgh) & 41 & 55.5 & 60.5 & 73.5 & 57.9 & 107 & 1 & 70 \\
\hline Dissolved Solids (mgle) & 134 & 185 & 116 & 194 & 157 & 1225 & 245 & \\
\hline Total Lead fug/L) & 9 & 13 & 15 & 11 & 12 & 1.5 & 5 & 1.52 \\
\hline Total Copper (ug/L) & 15 & 14.5 & 15 & 11 & 13.9 & 1.5 & $<10$ & \\
\hline Total Zinc (ugiL) & 80 & 180 & 245 & 60 & 141 & 16 & 6 & \\
\hline Total Cadmium (ugh) & 0.75 & 0.96 & 2 & $<1$ & 1.05 & 1 & $<1$ & \\
\hline Total Chromium (ught) & 2.1 & 10 & 7 & 3 & 5.5 & $<10$ & 7.5 & \\
\hline Total Nickel (wg/L) & $<10$ & 11.8 & 8.3 & 4 & 7.3 & & & \\
\hline BOD (mgh) & 25.5 & 23 & 14 & 6.4 & 17.2 & 4 & 0.5 & \\
\hline COD (mgll $)$ & 49.5 & 116 & 45.5 & 59 & 67.5 & & & 40 \\
\hline Oil and Grease (mg/L) $)^{\star \star}$ & 1.7 & 9 & 3 & 0.4 & 3.5 & & & \\
\hline Fec Coliform $(\mathrm{col} .1100 \mathrm{~m} \text { ) })^{* *}$ & 20,000 & 6,900 & 9,700 & 53,000 & 22,400 & & 200 & \\
\hline Focal Strep $(\mathrm{col} .1100 \mathrm{mll})^{* *}$ & 56,000 & 18.000 & 6,100 & 26,000 & 26,525 & & & \\
\hline
\end{tabular}

\# calculated as ang of land uses $1 \mathrm{t}-14$

* applled to at subcatergories with th the land use type

**avefage concantrations base on Instantaneous rather than flow-averaged samples Fonte: Maidment (1996).

Para validar as cargas e concentrações estimadas são utilizados dados de medição de qualidade da água (107 parâmetros) referente a 37 estações de monitoramento num período de 10 anos.

No Estado de Mato Grosso foi criado um Sistema Integrado - SIBAC, ZEILHOFER e col. (2002) que possibilitará o controle e manejo dos recursos hídricos na bacia do Rio Cuiabá, de $29000 \mathrm{Km}^{2}$ de extensão de intensa atividade agrícola, visando: 
- aquisição, organização e publicação de dados espaciais e não espaciais relevantes para um monitoramento ambiental da bacia com enfoque nos recursos hídricos;

- análises estatísticas para teste de qualidade e consistência dos dados;

- desenvolvimento de um Sistema de Informação Geográfica (SIG) adaptado para apoiar tomada de decisões no manejo dos recursos hídricos;

- modelações de quantidade e qualidade das águas na bacia com simulações de impactos de fontes poluidoras pontuais e não pontuais

O SIBAC é constituído por um Sistema de Gerenciador de Banco de Dados (SGBD) desenvolvido em Microsoft Access e um Sistema de Informação Geográfica (SIG) implementado em ArcView. Toda funcionalidade do SGBD poderá ser acessada também através da Interface do SIG.

Foram iniciados trabalhos (ZEILHOFER e col. 2003) para a integração do modelo QUAL2E, de simulação de qualidade da água, em ambiente SIG, adaptando Scripts que foram desenvolvidos para o ambiente BASINS, sistema também disponibilizado pela Environmental Protection Agency - EPA, Agência Ambiental Americana.

Apesar de promover a integração de um modelo de qualidade de água, dentro de um ambiente SIG, objetivando disponibilizar uma ferramenta que permita a realização de todos os passos da simulação a partir de um único aplicativo, ZEILHOFER e col. (2003) considera que a integração de um modelo hidrológico ou, mais especificamente, de um modelo de qualidade de água em um ambiente SIG, não se justifica pela necessidade do SIG em processar a modelagem, mas por sua utilidade na melhoria da estimativa de parâmetros de modelos conceituais, na parametrização das unidades espaciais em modelos distribuídos por sub-bacias, na subdivisão automatizada da bacia em unidades hidrológicas similares, na contextualização espacial dos resultados e na simplificação da aplicação operacional do modelo.

ZEILHOFER e col. (2003) conclui que o desenvolvimento e a adaptação do SIBAC para uma integração do modelo de qualidade de água QUAL2E mostrou ser 
uma tarefa abrangente, envolvendo a análise de diversos aplicativos e a programação de softwares SGBD e SIG. Concluiu também que a utilização de softwares comerciais para a implementação do modelo pode ser considerada um fator limitante para distribuição do sistema devido a necessidade de dispor de funcionalidades abrangentes para processamento de dados alfanuméricos e espaciais, análise espacial e visualização impossibilita, entretanto, para instituições de menor porte, a criação de aplicativos completamente independentes.

NARANJO (1997) considera que modelos de poluição não pontuais são basicamente uma descrição do processo de transformação hidrológica de precipitação-escoamento superficial (runoff) com componentes de qualidade associados, e apresenta os passos básicos da modelagem. Dentre os principais conceitos destacam-se:

- aponta os parâmetros nitrogênio total, fósforo total, DBO e coliformes fecais como os parâmetros selecionados para quantificar poluição não pontual;

- indica dois grupos principais de uso do solo e categoriza suas divisões, a saber: áreas rurais (não urbanas) - agricultura, floresta, terreno ocioso (terreno não utilizado por propósitos de atividades agrícolas) e pântano (várzea); áreas urbanas - alta densidade urbana, terreno residencial e terreno industrial;

- define as Concentrações Estimadas Médias (EMCs do inglês) como valores dos poluentes típicos no runoff, sendo estes parâmetros diretamente associados ao uso do solo nas áreas de drenagem, e constante independentemente da duração e intensidade dos eventos de precipitação;

- padroniza valores de coeficientes de runoff obtidos de literatura associados a cada uso do solo, a serem utilizados no cálculo do runoff total, obtido da multiplicação da precipitação total pelos coeficientes naquela respectiva bacia;

A metodologia utilizada por NARANJO (1997) é similar a de MAIDMENT AND SAUNDERS (1996), diferindo em relação à consideração que os poluentes 
estão sujeitos a processo de decaimento, ou seja, não são considerados parâmetros conservativos, enquanto escoam no solo, ficando a cargo dos modelos de qualidade o decaimento que ocorre ao longo dos cursos d'água. Os coeficientes de decaimento para nitrogênio, fósforo e DBO são admitidos como de primeira ordem.

NARANJO (1997) leva em consideração também uma carga per capita referente à poluição pontual devido a fontes pontuais domésticas e industriais (pequeno porte) espalhadas. Aponta inclusive valores, em função das condições de vida da população, para o caso de não haver levantamentos específicos da área em análise.

A metodologia de NARANJO (1997), que utiliza o SIG ArcView para alimentar o modelo de qualidade MIKE 11 foi aplicada para bacia do rio Iguaçu. Assim como a aplicação da metodologia de MAIDMENT AND SAUNDERS (1996) esta foi aplicada apenas para avaliações anuais médias, entretanto NARANJO (1997) aponta que avaliações mensais médias podem ser facilmente avaliadas através da metodologia desenvolvida. 


\section{MATERIAIS E MÉTODOS}

\section{1 Área de Estudo}

A bacia do rio Paraíba do Sul se estende por territórios pertencentes a três estados da Região Sudeste: São Paulo, Rio de Janeiro e Minas Gerais.

A parte paulista da bacia está localizada entre as coordenadas $22^{\circ} 24^{\prime}$ e $23^{\circ} 39^{\prime}$ de latitude Sul e $44^{\circ} 10^{\prime}$ e $46^{\circ} 26^{\prime}$ de longitude Oeste, abrangendo uma área de drenagem de $13.605 \mathrm{~km}^{2}$, constituindo a Unidade de Gerenciamento de Recursos Hídricos do Paraíba do Sul, UGRHI-2, uma das 22 unidades de gerenciamento do Estado de São Paulo, correspondente à totalidade de 34 municípios inseridos na região do Vale do Paraíba, no leste do Estado de São Paulo.

A delimitação da bacia paulista é bem definida pelas serras que formam o vale, (Serra do Mantiqueira, do Mar e da Bocaina), conforme pode-se observar no mosaico de imagens de satélite apresentado na figura 3 a seguir.

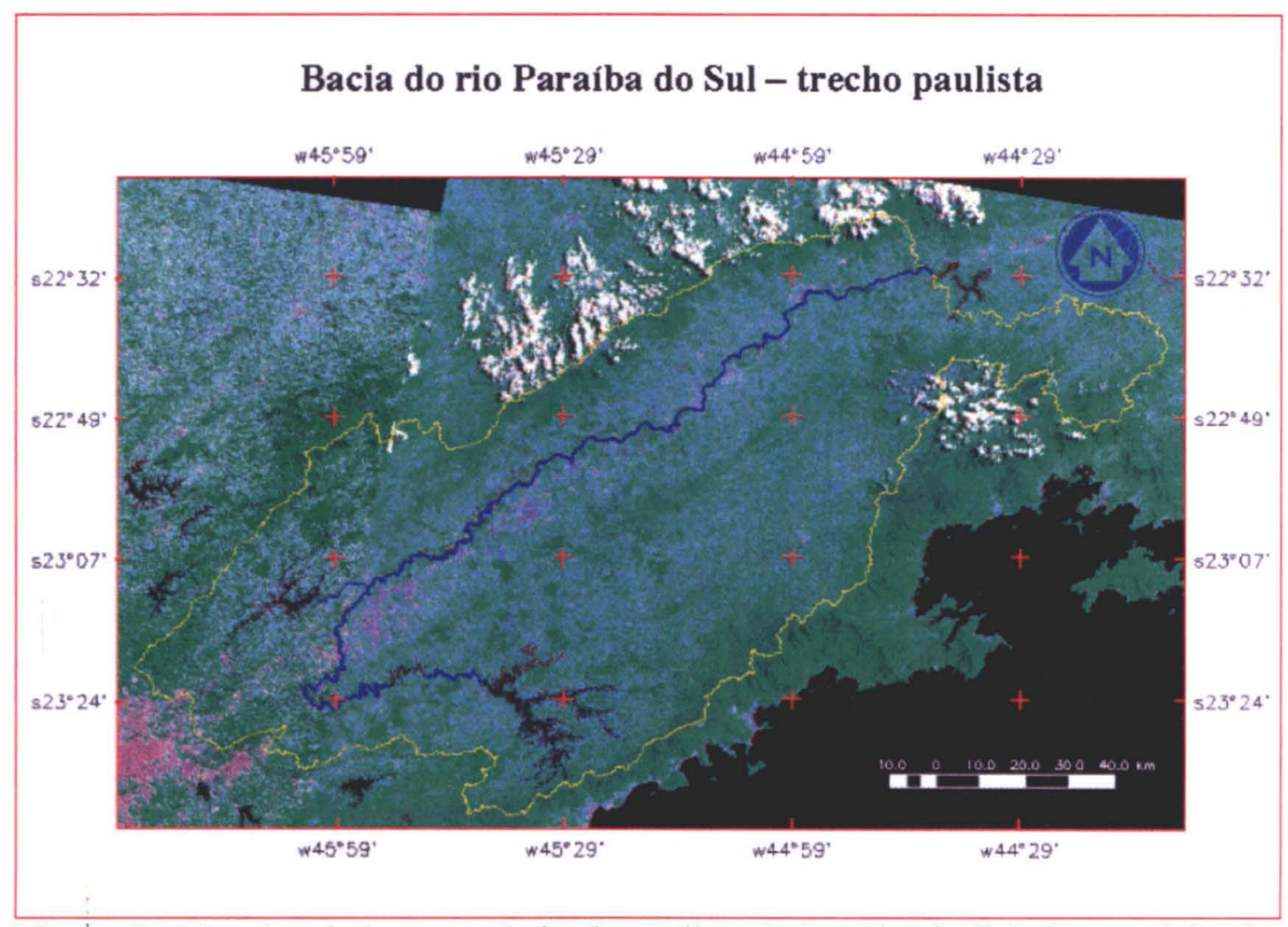

Figura 3 - Mosaico de imagens da bacia paulista do Paraíba do Sul. Composição das bandas 3, 4 e 5 do satélite Landsat, de junho/2002. 
A UGRHI-2 agrega 503 sub-bacias afluentes do Rio Paraíba do Sul, porém foi estabelecida, pelo Comitê de Bacia do Paraíba do Sul (CBH-PS), a diretriz de adotar as bacias hidrográficas dos afluentes do rio Paraíba do Sul como unidades de análise dos usos e de planejamento das ações relativas à utilização dos recursos hídricos do segmento paulista da bacia do rio Paraíba do Sul. Desta forma no Plano de Bacia da UGRHI-2, CPTI (2001) foram priorizadas 139 sub-bacias de afluentes diretos do Rio Paraíba do Sul em território paulista, mais um conjunto de sub-bacias que afluem no referido rio no Estado do Rio de Janeiro, delimitadas no SPRING, constituindo Plano de Informação, conforme apresentado na figura 4 e relacionadas no 1 , a partir de listagem do DAEE - Taubaté.

Sua gestão é de responsabilidade do Comitê das Bacias Hidrográficas do Paraíba do Sul (CBH-PS), além do CEIVAP - Comitê de Integração do Rio Paraíba do Sul, responsável pela integração com os estados de Minas Gerais e Rio de Janeiro, por onde passa o rio.

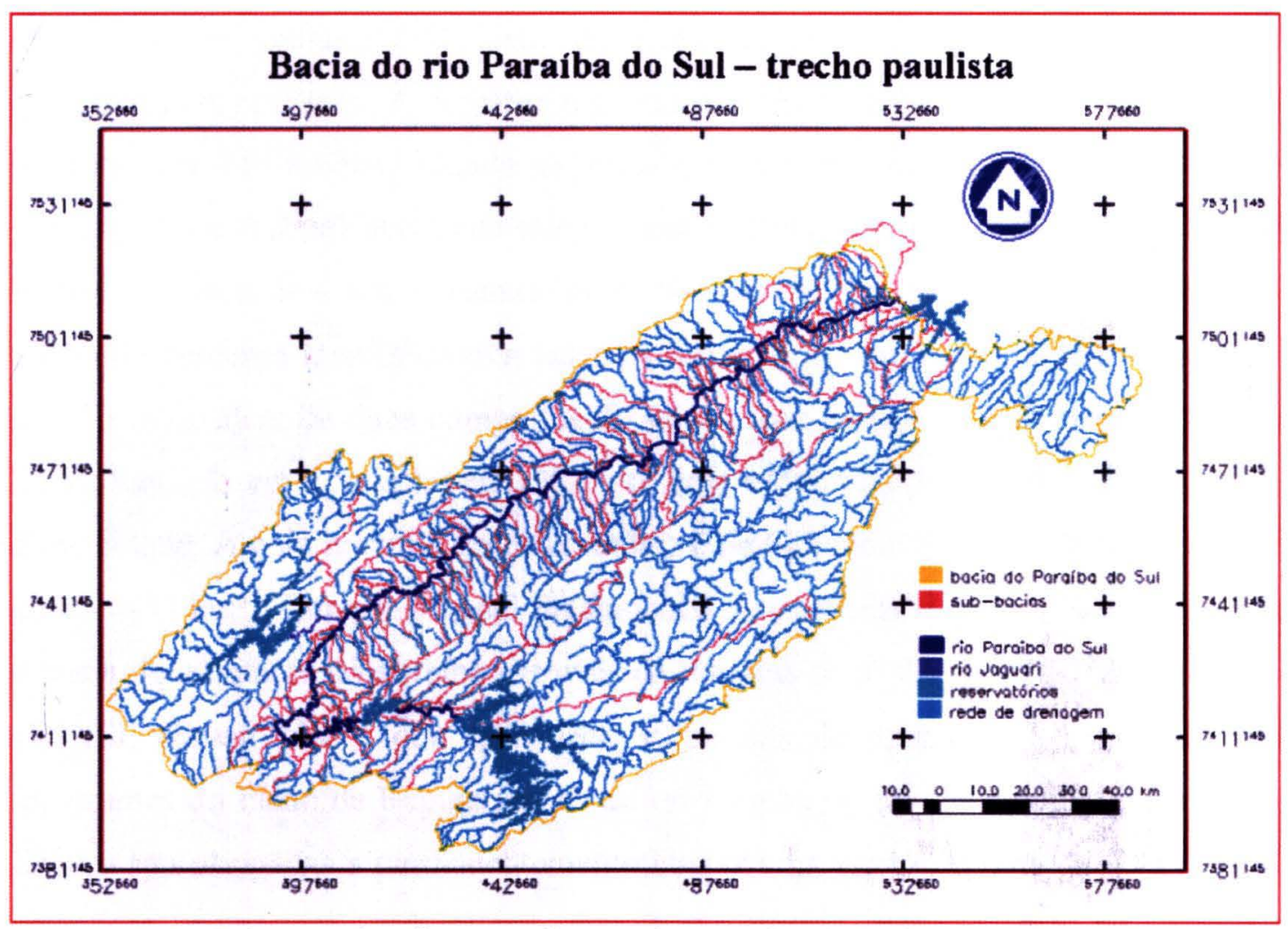

Figura 4 - Sub-bacias de afluentes diretos do Paraíba do Sul no estado de São Paulo. 


\subsubsection{Os Recursos Hídricos na bacia do Paraíba do Sul}

O rio Paraíba do Sul, formado pela confluência dos rios Paraibuna e Paraitinga, nasce no Estado de São Paulo a cerca de $20 \mathrm{~km}$ em linha reta do Oceano Atlântico e percorre cerca de $900 \mathrm{~km}$ antes de desembocar no mesmo oceano, em Atafona, distrito do Município de São João da Barra, no Estado do Rio de Janeiro. Ao longo desse percurso, além de atravessar esses dois Estados, serve, por cerca de $100 \mathrm{~km}$, de divisa entre os Estados de Minas Gerais e Rio de Janeiro.

\subsubsection{Disponibilidade e Uso}

Atualmente o rio Paraíba do Sul é formado a partir das águas represadas pelas barragens dos rios Paraibuna e Paraitinga, que formam uma represa de cerca de 176 $\mathrm{km}^{2}$ de área. $\mathrm{O}$ reservatório, único formado por esses barramentos, tem como principal papel regularizar as vazões do Paraíba mediante a operacionalização de seus $2.636 \mathrm{hm}^{3}$ (volume útil). Vem sendo operado pela CESP, desde 1978, ano em que entrou em operação. A descarga máxima, através de turbinas e válvulas, é de 120 $\mathrm{m}^{3} / \mathrm{s}$ na cota 714 metros, quando se inicia o vertimento através de um vertedor de descarga livre (tulipa) que pode atingir uma descarga de $671 \mathrm{~m}^{3} / \mathrm{s}$ na cota 716,50 metros. A cerca de $4 \mathrm{~km}$ à jusante, outro barramento, em Santa Branca, controla a vazão de descarga através de três válvulas dispersoras com capacidade de liberação de $275 \mathrm{~m}^{3} / \mathrm{s}$, além de duas comportas de setor capaz de descarregar até $1.300 \mathrm{~m}^{3} / \mathrm{s}$. Tendo entrado em operação em 1952, até hoje é operada pela Light - Serviços de Eletricidade. A cota máxima do reservatório é de 622 metros e seu volume útil é de apenas $434 \mathrm{hm}^{3}$. Cumpre o papel fundamental de controlar a vazão efluente de toda a bacia de montante do Paraíba. Através da Portaria de $\mathrm{n}^{\circ} 22$, datada de 24/2/77, do DNAEE (Brasil 1977), que estabelece as normas de operação dos reservatórios integrantes do Plano de Regularização do rio Paraíba do Sul, as comportas de Santa Branca são obrigadas a permanentemente liberar uma vazão mínima de $40 \mathrm{~m}^{3} / \mathrm{s}$. As restricões operativas hidráulicas dos reservatórios pertencentes ao Sistema Interligado Nacional - SIN encontram atualizadas no relatório "Inventário das Restrições Operativas Hidráulicas dos Aproveitamentoss Hidrelétricos” (ONS 2002). 
Após percorrer cerca de $90 \mathrm{~km}$, o rio Paraíba do Sul recebe as águas de um de seus maiores afluentes, o rio Jaguari (bacia de $1730 \mathrm{~km}^{2}$ ), que tem suas águas também represadas, compondo o sistema regulador das vazões. À montante do exutório de sua bacia se ergue a barragem do Jaguari, criando um reservatório capaz de reter volume útil de $793 \mathrm{~km}^{3}$. Até a cota 623 metros, descarrega suas águas através de turbinas e válvulas num máximo de $60 \mathrm{~m}^{3} / \mathrm{s}$, e a partir de então inicia o vertimento através de um vertedor de descarga livre descarregando até $623 \mathrm{~m}^{3} / \mathrm{s}$. Pelos mesmos motivos do reservatório de Santa Branca, também está limitada sua vazão mínima em $10 \mathrm{~m}^{3} / \mathrm{s}$.

Já no Estado do Rio de Janeiro, logo que o Paraíba adentra o Estado, no município de Engenheiro Passos, ergue-se mais uma barragem, a do Funil. Seu reservatório, como os anteriores do Alto Paraíba, tem como finalidade otimizar a disponibilidade de $250 \mathrm{~m}^{3} / \mathrm{s}$ de água em Barra do Piraí (RJ), cerca de $100 \mathrm{~km}$ à jusante. Nesse ponto, comportas de setor interceptam o curso do rio Paraíba, garantindo a permanência de pelo menos $90 \mathrm{~m}^{3} / \mathrm{s}$ para atender às necessidades de jusante.

Na figura 5 a seguir é apresentado o diagrama unifilar do rio Paraíba do Sul, obtido do relatório do PQA (ICF-KAISER e LOGOS 1999) mostrando esquematicamente a posição dos aproveitamentos citados, além dos demais existentes nos outros estados, assim como as vazões mínimas que devem garantir a jusante. 


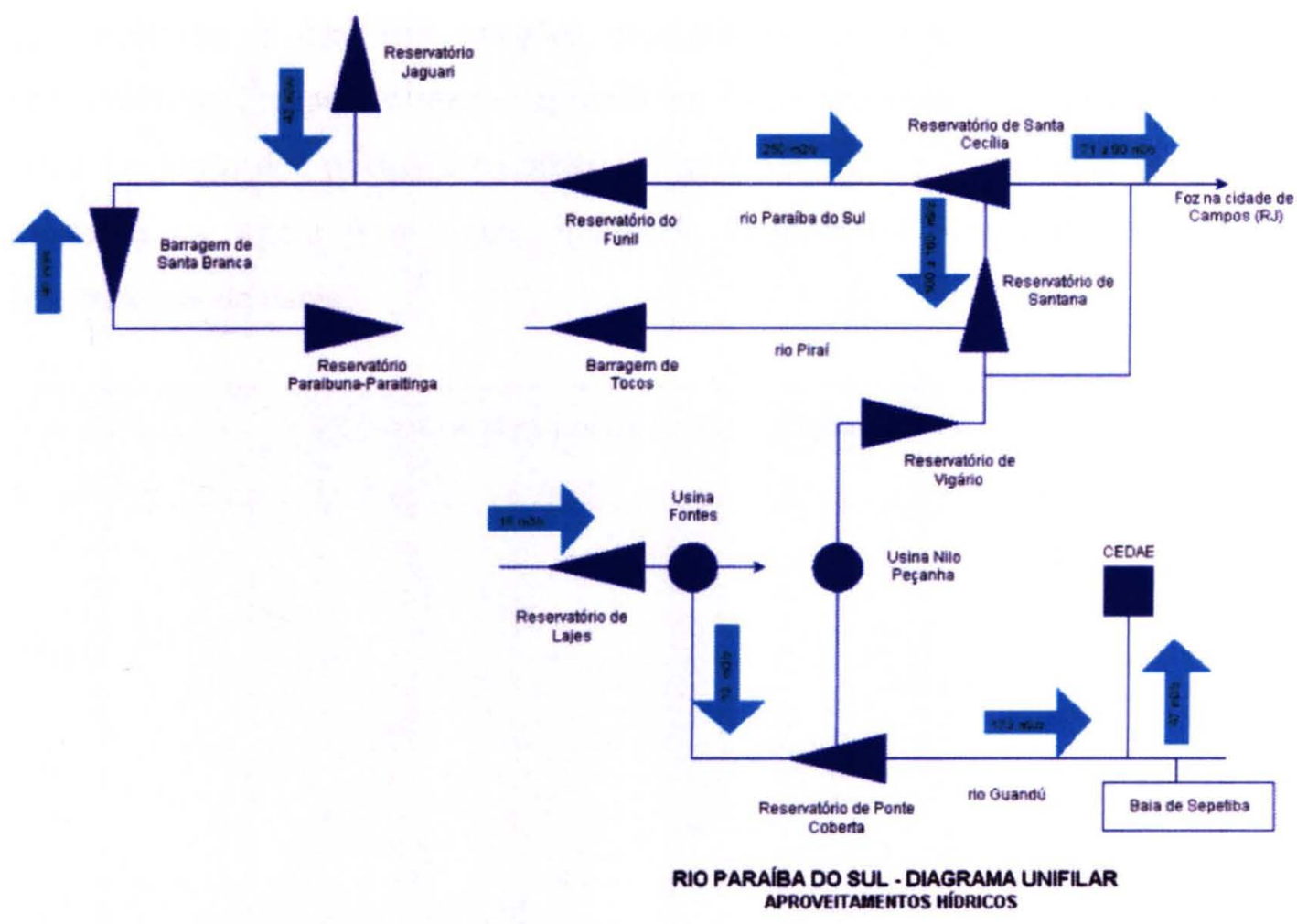

Figura 5 - Diagrama Unifilar dos aproveitamentos hídricos do Paraíba do Sul. Fonte:_ICF-KAISER e LOGOS 1999.

Criado em 1998, com a finalidade de operar o Sistema Interligado Nacional SIN e administrar a rede básica de transmissão de energia em nosso país, o Operador Nacional do Sistema Elétrico - ONS tem a missão institucional de assegurar aos usuários do SIN a continuidade, a qualidade e a economicidade do suprimento de energia elétrica. Para tanto é responsável por zelar pelas regras operativas dos aproveitamentos hidrelétricos (ONS 2002). As restricões consideradas referem-se a vazões ou níveis máximos e mínimos em seções e trechos de rio, limitações de descargas máximas e mínimas em usinas, limites para os níveis máximos e mínimos nos reservatórios, taxas de deplecionamento e de enchimento e, ainda, taxas máximas de variação de defluências.

\section{Fluviometria e Pluviometria}

Foi feito o levantamento de todos os postos fluviométricos e pluviométricos, pertencentes ao trecho paulista da bacia, que constam no Sistema de Informações Hidrológicas da Agência Nacional de Águas (ANA 2001). Das 152 estações 
fluviométricas e das 305 estações pluviométricas, 10 e 17 estações fluvio e pluviométricas, respectivamente, apresentam dados recentes (pelo menos até 2002). Vide a relação dos postos fluviométricos no Anexo 2 e a localização geográfica é mostrada na figura 6 a seguir, incluindo também os pontos de descarga dos reservatórios da bacia.

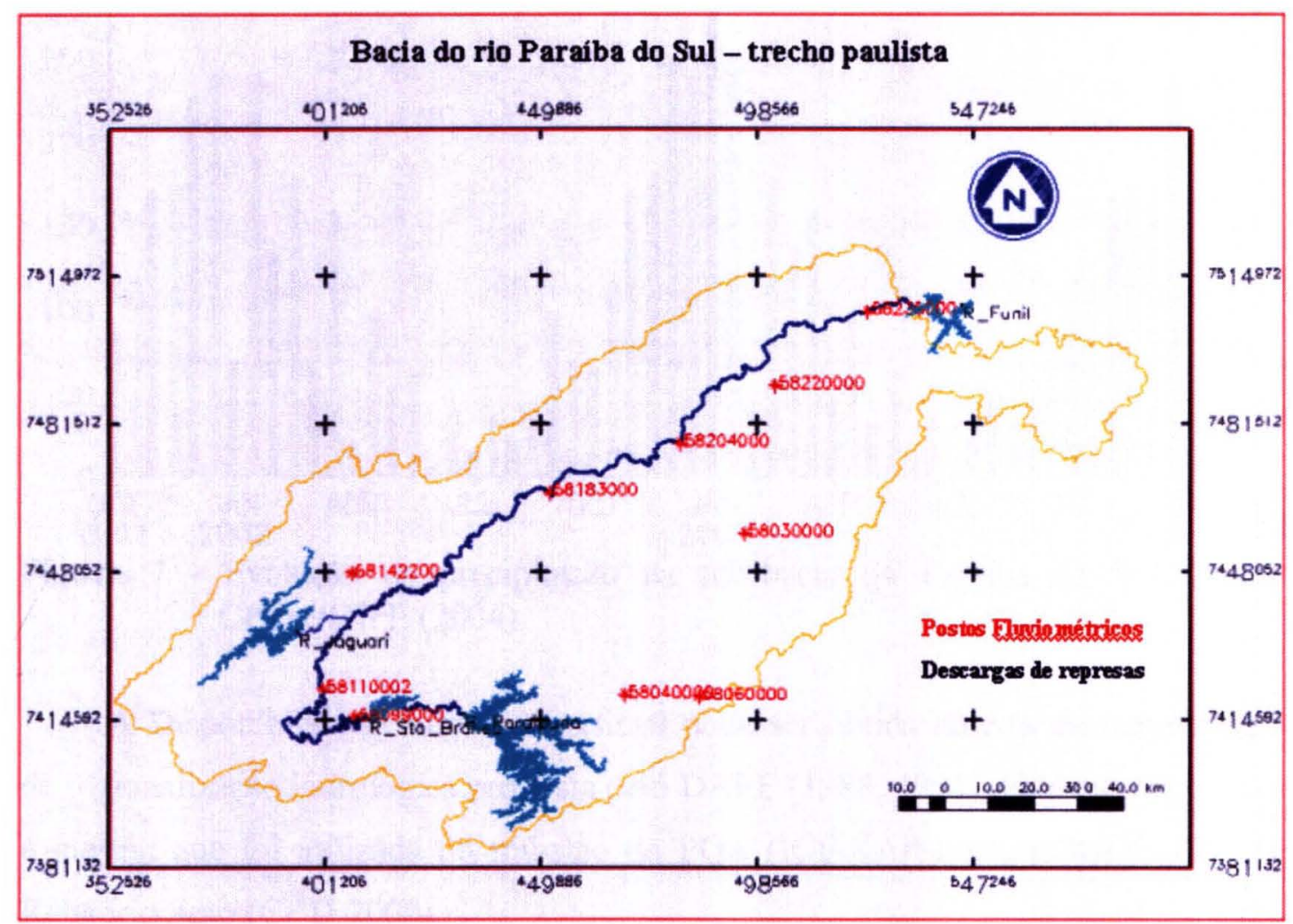

Figura 6 - Postos fluviométricos e de descargas dos reservatórios na bacia paulista do Paraíba do Sul.

A figura 7 apresenta o gráfico de evolução da chuva, para o período de outubro/2001 a janeiro/2004, e a precipitação média de longo termo representativos da bacia do Paraíba do Sul como um todo, segundo CPTec/INPE (2004), Disponível em <URL: http://www.cptec.inpe.br/energia/bacias/bacia paraibadosul.shtml $>$. 


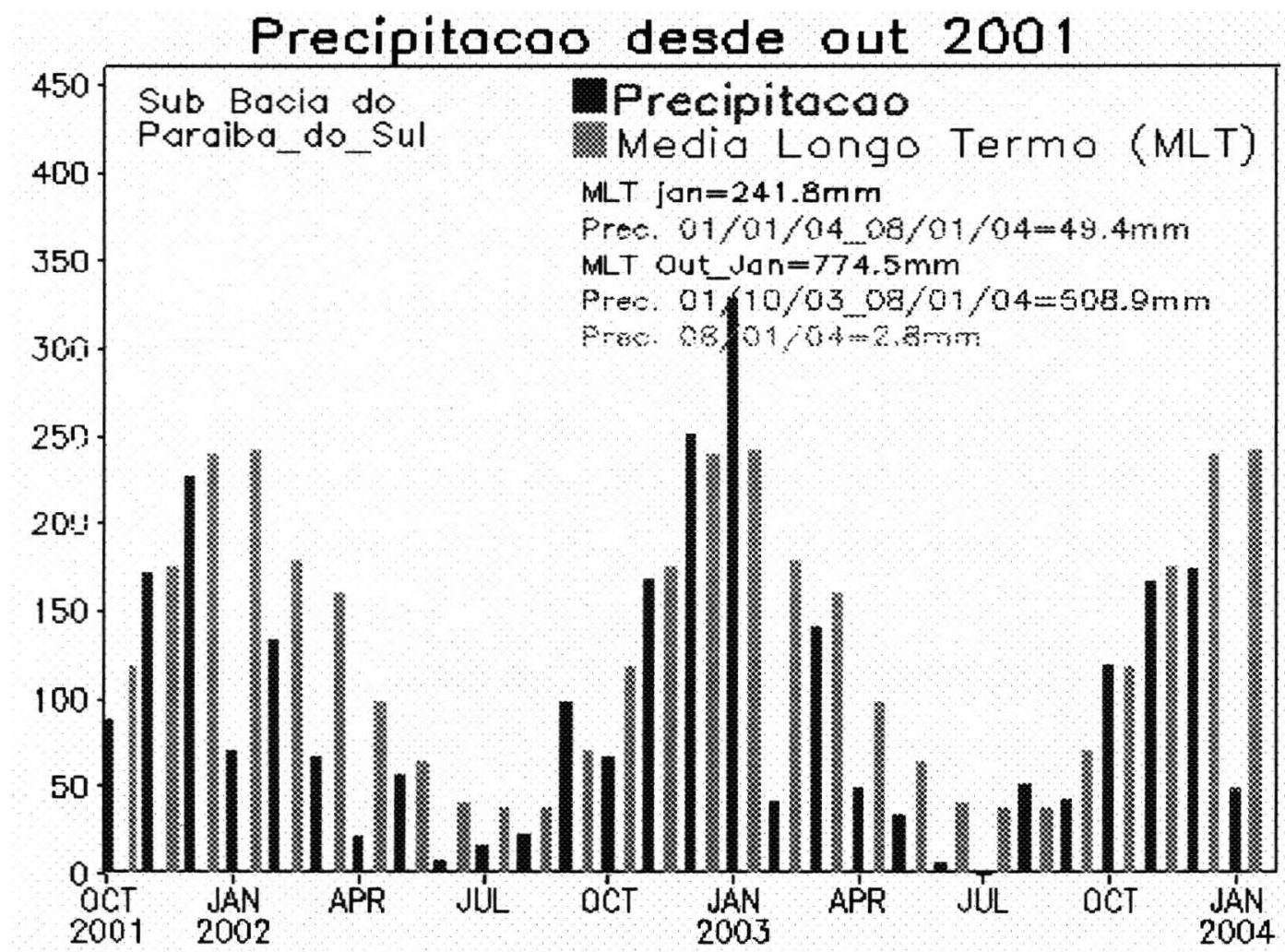

Figura 7 - Evolução da precipitação na sub-bacia do Paraíba do Sul. Fonte: CPTec/INPE (2004).

A Disponibilidade hídrica superficial pode ser obtida através de metodologia de regionalização hidrológica proposta pelo DAEE (1988, 1994). Esta metodologia é a mesma que foi utilizada no trabalho do PQA (ICF-KAISER e LOGOS 1999) e Relatório Zero (CPTI 2000).

O relatório zero CPTI (2000) aponta em sua síntese final a diversidade dos usos dos recursos hídricos na bacia do Paraíba do Sul:

- a UGRHI-2 possui uma população total de 1.658 .002 habitantes sendo que 1.506.713 são considerados habitantes da zona urbana. Dos 34 municípios, totais ou parcialmente, localizados nessa unidade de gerenciamento de recursos hídricos, 12 captam a água de seu abastecimento público diretamente da calha do rio Paraíba, 20 captam água superficial de seus afluentes diretos e dois municípios (Potim e Caçapava) possuem o seu sistema de abastecimento de água através da captação de água subterrânea.

- na UGRHI-2, 25\% do total de esgoto lançado (16 municípios) no rio Paraíba do Sul é tratado e 18 municípios lançam o esgoto "in natura"; 
- a potencialidade de aproveitamento hidroagrícola na várzea do rio Paraíba do sul no Estado de São Paulo é de 42.000 ha. Atualmente são cultivados 14.000 ha, dos quais $50 \%$ são ocupados pela cultura do arroz.

\subsubsection{Qualidade das Águas}

A rede de monitoramento de qualidade das águas interiores do estado de São Paulo, criada em 1974 e operada pela CETESB, em atendimento à Lei Estadual N.o 118 (São Paulo 1973), possui 13 pontos de amostragem na UGRHI - 2.

No Relatório de Qualidade das Águas interiores do estado de São Paulo, elaborado anualmente pela CETESB (2003 e 2004), são apresentados os resultados de parâmetros de qualidade das águas da bacia do Paraíba do Sul, em São Paulo, referente a amostragens bimensais realizadas nos locais indicados na tabela 2 a seguir.

Tabela 2 - Descrição dos Pontos de Amostragem de qualidade de água da CETESB na bacia do Paraíba do Sul.

\begin{tabular}{|c|c|c|c|c|c|}
\hline 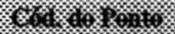 & 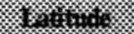 & 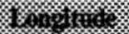 & 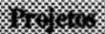 & 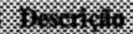 & 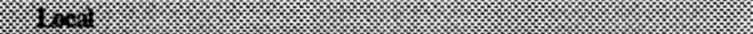 \\
\hline JAGI02900 & $23^{\circ} 10^{\prime} 21^{\prime \prime}$ & $45^{\circ} 54^{\prime} 49^{\prime \prime}$ & RB & Rio Jaguari & Próximo à foz no rio Paraíba, no munićpio de São José dos Campos. \\
\hline JAGJ00200 & $23^{\circ} 17^{\prime} 38^{\prime \prime}$ & $46^{\circ} 14^{\prime} 02^{\prime \prime}$ & $\mathrm{RB}$ & $\begin{array}{l}\text { Reserv. do } \\
\text { Jaguari }\end{array}$ & $\begin{array}{l}\text { Ponte na rodovia SP } 056 \text { que liga Santa Isabel a Igaratá, no município de } \\
\text { Santa Isabel. }\end{array}$ \\
\hline PARB02050 & $23^{\circ} 22^{\prime} 32^{\prime \prime}$ & $45^{\circ} 53^{\prime} 12^{\prime \prime}$ & $\mathrm{RB}$ & & Capatação de Santa Branca, no bairro Angola de Cima. \\
\hline PARB02100 & $23^{\circ} 22^{\prime} 05^{\prime \prime}$ & $45^{\circ} 53^{\prime} 59^{\prime \prime}$ & $\mathrm{RB}$ & & Ponte na rodovia SP-77, no trecho que liga Jacareí a Santa Branca. \\
\hline PARB02200 & $23^{\circ} 18^{\prime} 48^{\prime \prime}$ & $45^{\circ} 58^{\prime} 20^{\prime \prime}$ & $\mathrm{RB}$ & & Junto à captação do município de Jacareí \\
\hline PARB02300 & $23^{\circ} 11^{\prime} 42^{\prime \prime}$ & $45^{\circ} 55^{\prime} 48^{\prime \prime}$ & RB & & Ponte de acesso ao loteamento Urbanova, em São José dos Campos. \\
\hline PARB02310 & $23^{\circ} 11^{\prime} 16^{\prime \prime}$ & $45^{\circ} 55^{\prime} 04^{\prime \prime}$ & $\mathrm{RB}$ & & Na captação de São José dos Campos. \\
\hline PARB02390 & $23^{\circ} 04^{\prime} 59^{\prime \prime}$ & $45^{\circ} 43^{\prime} 08^{\prime \prime}$ & SED & Rio Paraíba & Rio Paraiba, na futura régua do DAEE, em Caçapava \\
\hline PARB02400 & $23^{\circ} 04^{\prime} 54^{\prime \prime}$ & $45^{\circ} 42^{\prime} 40^{\prime \prime}$ & $\mathrm{RB}$ & do Sul & $\begin{array}{l}\text { Ponte na rua do Porto, no trecho que liga Caçapava ao bairro Menino } \\
\text { Jesus. }\end{array}$ \\
\hline PARB02490 & $22^{\circ} 57^{\prime} 40^{\prime \prime}$ & $45^{\circ} 33^{\prime} 10^{\prime \prime}$ & $\mathrm{RB}$ & & Na captação da SABESP em Tremembé. \\
\hline PARB02530 & $22^{\circ} 54^{\prime} 42^{\prime \prime}$ & $45^{\circ} 28^{\prime} 13^{\prime \prime}$ & $\mathrm{RB}$ & & Na captação da SABESP de Pindamonhangaba \\
\hline PARB02600 & $22^{\circ} 50^{\prime} 40^{\prime \prime}$ & $45^{\circ} 14^{\prime} 04^{\prime \prime}$ & $\mathrm{RB}$ & & Na captação de Aparecida \\
\hline PARB02700 & $22^{\circ} 42^{\prime} 12^{\prime \prime}$ & $45^{\circ} 0710^{\prime \prime}$ & $\mathrm{RB}$ & & Ponte na rodovia BR-459, no trecho que liga Lorena a Piquete. \\
\hline PARB02900 & $22^{\circ} 32^{\prime} 32^{\prime \prime}$ & $44^{\prime} 46^{\prime} 26^{\prime \prime}$ & RB & & Ponte na cidade de Queluz. \\
\hline PTEI02900 & $23^{\circ} 12^{\prime} 14^{\prime \prime}$ & $46^{\circ} 00^{\prime} 50^{\prime \prime}$ & RB & Rio Paratei & $\begin{array}{l}\text { Ponte na estrada de acesso ao Res. Jaguari, próximo à cervejaria Brahma, } \\
\text { em Jacaré. }\end{array}$ \\
\hline SANT00100 & $23^{\circ} 20^{\prime} 05^{\prime \prime}$ & $45^{\circ} 4743^{\prime \prime}$ & $\mathrm{RB}$ & $\begin{array}{l}\text { Reserv. } \mathrm{St}^{\mathrm{T}} \\
\text { Branca }\end{array}$ & No meio do corpo central, na junção dos braços Capivari e Paraibuna. \\
\hline
\end{tabular}

A localização dos pontos de amostragem em relação aos cursos d'águas principais é indicada na figura 8 que apresenta a sobreposição dos Planos de 
Informações (PI) do rio Paraíba do Sul e reservatórios com o PI referente aos pontos de amostragem da CETESB, elaborados no SPRING.

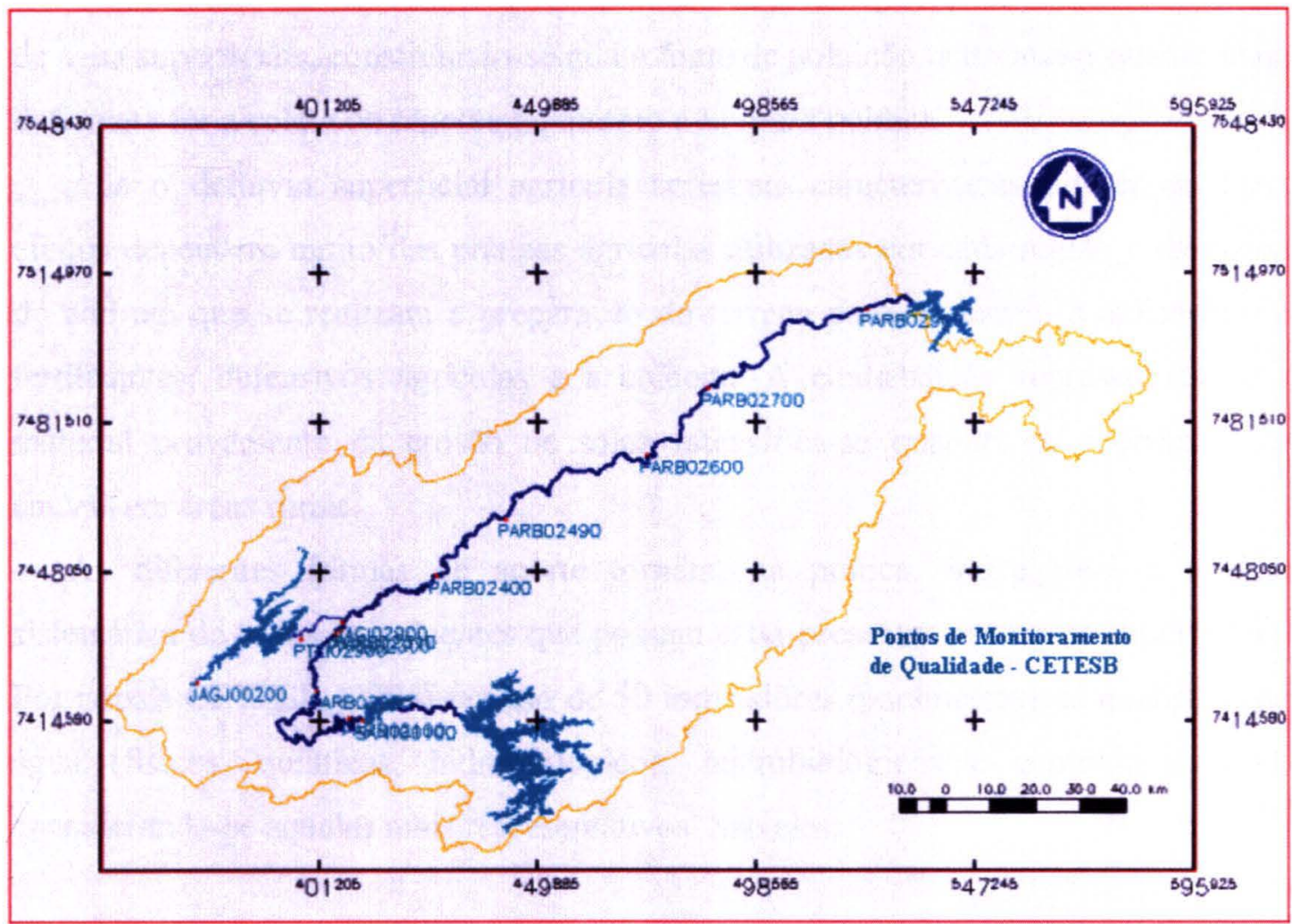

Figura 8 - Localização dos pontos de amostragem da CETESB na UGRHI-02.

Variáveis de qualidade das águas

A poluição das águas tem como origem diversas fontes, dentre as quais se destacam:

- efluentes domésticos;

- efluentes industriais;

- carga difusa urbana e agrícola.

Essas fontes estão associadas ao tipo de uso e ocupação do solo. Cada uma dessas fontes possui características próprias quanto aos poluentes que carream (por exemplo, os esgotos domésticos apresentam compostos orgânicos biodegradáveis, nutrientes e bactérias). Já a grande diversidade de indústrias existentes no Estado de São Paulo faz com que haja uma variabilidade mais intensa nos contaminantes lançados aos corpos de água, incluindo-se os já citados e muitos outros que estão relacionados aos tipos de matérias-primas e processos industriais utilizados. 
Em geral, o deflúvio superficial urbano contém todos os poluentes que se depositam na superfície do solo. Quando da ocorrência de chuvas, os materiais acumulados em valas, bueiros, etc., são arrastados pelas águas pluviais para os cursos de água superficiais, constituindo-se numa fonte de poluição tanto maior quanto mais deficiente for a coleta de esgotos ou mesmo a limpeza pública.

Já o deflúvio superficial agrícola apresenta características diferentes. Seus efeitos dependem muito das práticas agrícolas utilizadas em cada região e da época do ano em que se realizam a preparação do terreno para o plantio, a aplicação de fertilizantes, defensivos agrícolas e a colheita. A contribuição representada pelo material proveniente da erosão de solos intensifica-se quando da ocorrência de chuvas em áreas rurais.

As diferentes formas de aporte tornam, na prática, inexeqüível a análise sistemática de todos os poluentes que possam estar presentes nas águas superficiais. Por isso, a CETESB (2004) faz uso de 50 indicadores (parâmetros) de qualidade de água (físicos, químicos, hidrobiológicos, microbiológicos e ecotoxicológicos), considerando-se aqueles mais representativos. São eles:

- variáveis físicas: absorbância no ultravioleta, coloração da água, série de resíduos (filtrável, não filtrável, fixo e volátil), temperatura da água e do ar e turbidez.

- variáveis químicas: alumínio, bário, cádmio, carbono orgânico dissolvido, chumbo, cloreto, cobre, condutividade específica, cromo total, demanda bioquímica de oxigênio $\left(\mathrm{DBO}_{5,20}\right)$, demanda química de oxigênio (DQO), fenóis, ferro total, fluoreto, fósforo total, manganês, mercúrio, níquel, óleos e graxas, ortofosfato solúvel, oxigênio dissolvido, $\mathrm{pH}$, potássio, potencial de formação de trihalometanos, série de nitrogênio (Kjeldahl, amoniacal, nitrato e nitrito), sódio, surfactantes e zinco.

- variáveis microbiológicas: coliformes termotolerantes, Cryptosporidium sp e Giardia sp.

- variáveis hidrobiológicas: clorofila $a$ e feofitina $a$, fitoplâncton, zooplâncton e bentos (sublitoral). 
- variáveis toxicológicas: ensaio de toxicidade aguda com a bactéria luminescente - $V$. fischeri (Sistema Microtox); ensaio de toxicidade aguda/crônica com o microcrustáceo Ceriodaphnia dubia; e ensaio de mutação reversa (conhecido como teste de Ames).

No Anexo 3 são apresentados os resultados das análises de qualidade da água na bacia do Paraíba do Sul, referente ao ano de 2003.

$\mathrm{O}$ índice de estado trófico de fósforo e clorofila $a$, para os rios, conforme CETESB (2004), varia em geral, de oligotrófico a mesotrófico ao longo do ano. Com relação aos rios Jaguari, Paraíba do Sul e Parateí, onde se situam os pontos de monitoramento JAGI 02900, PARB 02100, PARB 02300, PARB 02400, PARB 02700, PARB 02900 e PTEI 02900 foi calculado somente o IET(F), nesses pontos, ao longo do ano, sendo que as concentrações de fósforo total variaram indicando de estado oligotrófico a eutrófico, com destaque para Rio Paraíba do Sul nos pontos PARB 02490, 02600 e 02900 que apresentaram as maiores concentrações de fósforo total, conforme pode-se observar na figura 9 a seguir.

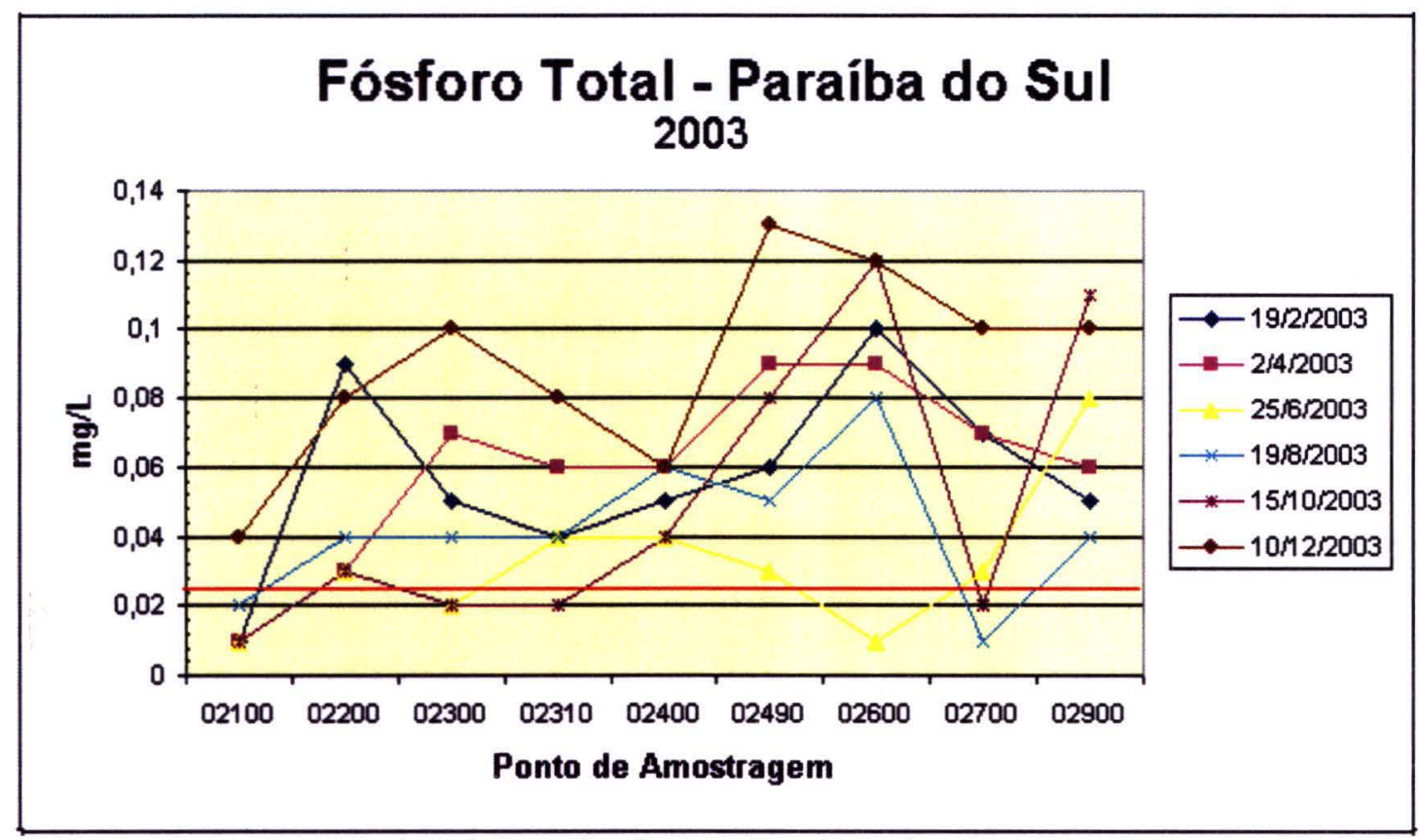

Figura 9 - Fósforo total ao longo do rio Paraíba do Sul - CETESB (2004). 
Em todos os pontos do rio Paraíba do Sul e do rio Jaguari os valores de coliformes termotolerantes encontraram-se acima dos limites estabelecidos pela Resolução CONAMA 357/05, conforme pode-se observar na figura 10 a seguir.

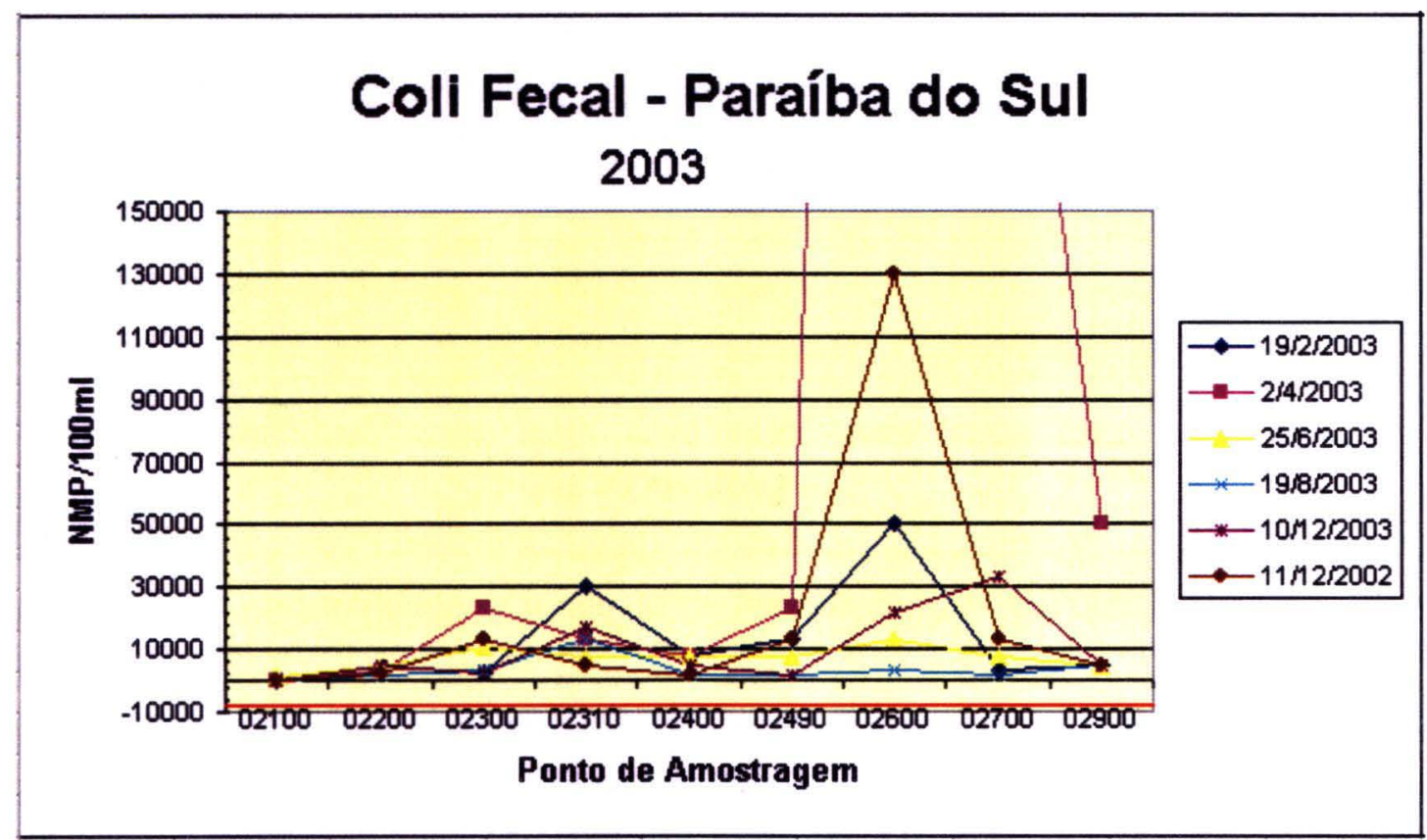

Figura 10 Número de coliformes fecais ao longo do rio Paraíba do Sul - CETESB (2004).

Esta situação indica que a carga de fósforo presente nesta bacia é proveniente do aporte de esgoto doméstico.

Em 2003, as águas do rio Paraíba do Sul apresentaram condutividade e turbidez, respectivamente, superior e inferior às médias históricas, caracterizando este período como sendo bastante crítico do ponto de vista de quantidade das águas (vide figura 11). A regra operativa dos reservatórios existentes nas cabeceiras do rio Paraíba do Sul tem acarretado uma baixa disponibilidade hídrica ao longo do rio, principalmente no período chuvoso, sendo portanto um dos motivos responsáveis pela piora de sua qualidade. 


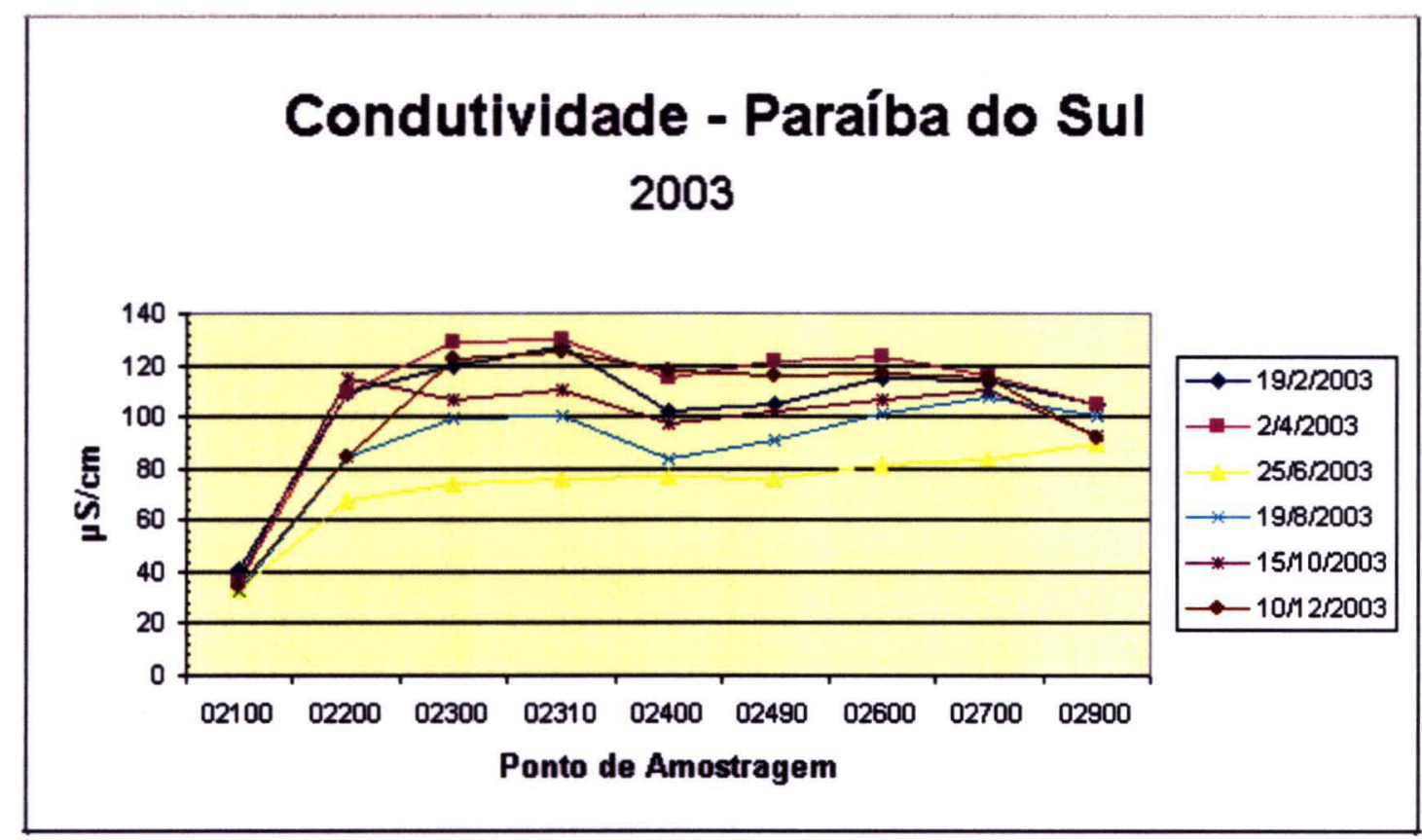

Figura 11 - Condutividade ao longo do rio Paraíba do Sul - CETESB (2004).

A partir de Jacareí (PARB 02200), o rio Paraíba do Sul recebe expressivas cargas poluidoras, atingindo seu ponto crítico na região de Caçapava (PARB 02400), onde se tem observado uma depleção nos níveis de oxigênio dissolvido ao longo dos últimos anos, apresentando uma média histórica de $3,8 \mathrm{mg} / \mathrm{L}$, contra uma média de 2,1 mg/L em 2003 (figura 12). É interessante salientar que os dados médios da $\mathrm{DBO}_{5,20}$, indicador responsável pelo consumo do oxigênio dissolvido, não retrataram nenhum valor médio elevado ao longo de todo o Rio Paraíba do Sul. Portanto, a condição hidráulica observada no rio em 2003, associada ao crescimento de plantas aquáticas, tem sido responsável pelo decaimento dos níveis de oxigênio dissolvido em suas águas. 


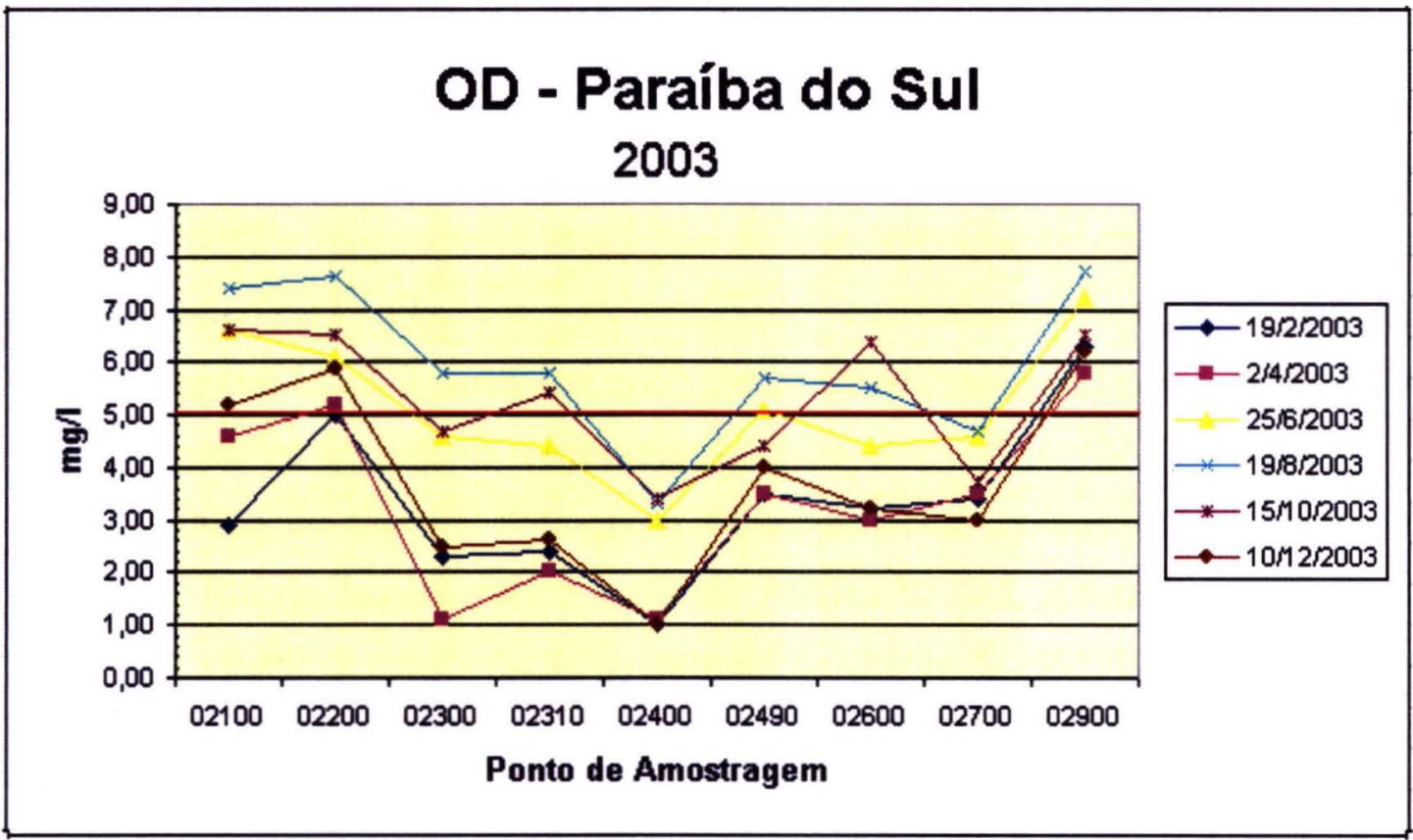

Figura 12 - Teor de oxigênio dissolvido ao longo do Paraíba do Sul - CETESB (2004).

\subsubsection{Estudos realizados na bacia paulista do Paraíba do Sul}

\section{Projeto Qualidade das Águas e Controle da Poluição Hídrica (PQA)}

Os estudos elaborados dentro do Projeto Qualidade das Águas e Controle da Poluição Hídrica (PQA), contratado pelo Ministério do Planejamento e Orçamento MPO para os trechos carioca, mineiro e desenvolvido entre maio de 1998 e maio de 1999 na parcela paulista, pelo Consórcio ICF-KAISER e LOGOS (1999), teve por escopo estabelecer um Programa de Investimento para a Gestão Integrada e Recuperação Ambiental da bacia hidrográfica do rio Paraíba do Sul, e tomou como base a avaliação dos fatores de vulnerabilidade ambiental da bacia. Estes levaram em conta especialmente esgotamento sanitário (coleta, afastamento e tratamento), abastecimento de água (captação, tratamento e distribuição), destinação dos resíduos sólidos (domésticos, industriais e hospitalares), drenagem urbana e irrigação, além de mecanismos institucionais e financeiros destinados a implementar o referido Programa de Investimento.

Visando o planejamento das ações foram realizadas simulações através da modelação matemática da qualidade da água, para a avaliação dos parâmetros 
característicos do rio Paraíba nos pontos de utilização, para os horizontes de 2003, 2010 e 2020 (para o estabelecimento de metas de médio e longo prazo).

Ressalta-se como um dos principais referenciais para o PQA (ICF-KAISER e LOGOS 1999) o mapeamento atualizado de Uso e Ocupação do Solo, realizado especialmente para esse fim, representando espacialmente os usos que se desenvolvem na bacia, a partir dos quais foram identificados os fatores e processos de preservação ou degradação e suas origens.

O mapa de Uso do Solo partiu do mapeamento existente elaborado pelo GEROE - Rio de Janeiro para a bacia do Paraíba do Sul, apresentado na escala 1:100.000, a partir de interpretação de imagens de satélite de 1993. Esse mapeamento foi devidamente atualizado para o ano de 1998, utilizando-se a mesma escala, adaptando-se a legenda para os objetivos do presente Estudo, com aferições em campo, retificações e adequações de padrões cartográficos.

Como método de trabalho para a etapa de identificação e classificação dos níveis de preservação e de degradação ocorrentes na bacia no trecho estudado, é citado no relatório do PQA (ICF-KAISER e LOGOS 1999) que o caminho escolhido foi o do cruzamento de variáveis naturais e antrópicas, através da superposição de layers, em meio informatizado, de modo a permitir a visualização dos variados processos atuantes e suas interações e o reconhecimento de áreas mais protegidas. $\mathrm{O}$ resultado é um diagnóstico cartografado, apresentado no formato digital, classificando as vulnerabilidades ambientais ocorrentes, tanto do ponto de vista da preservação - onde se destacam os elementos benéficos à conservação dos recursos hídricos -, quanto da degradação dos ambientes da bacia - onde se destacam fatores e processos que causam degradação.

Chegou-se aos seguintes níveis de classificação:

- níveis de preservação ambiental (controle, atenção, risco);

- níveis de degradação ambiental - potencial (controle, atenção) e efetiva (crítico). 
São as seguintes as tipologias identificadas e o percentual de ocorrência na porção estudada da bacia do Paraíba do Sul (tabela 3):

Tabela 3 - Uso e Ocupação/Cobertura do solo na bacia paulista do Paraíba do Sul

\begin{tabular}{|c|c|}
\hline 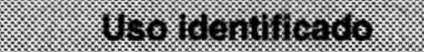 & 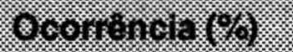 \\
\hline Matas & 17,35 \\
\hline Capoeiras & 13,43 \\
\hline Campo Natural de Altitude & 0,65 \\
\hline Reflorestamento & 4,99 \\
\hline Campo / Pastagem & 53,42 \\
\hline Pastagem de Várzea & 3,29 \\
\hline Agricultura & 0,36 \\
\hline Agricultura de Várzea & 1,06 \\
\hline Áreas com mineração & 0,21 \\
\hline Áreas com Solo Exposto & 0,16 \\
\hline Área Inundável & 0,11 \\
\hline Área Urbanizada & 2,90 \\
\hline Afloramento Rochoso & 0,09 \\
\hline Rios, lagos & 0,58 \\
\hline Reservatórios & 1,40 \\
\hline
\end{tabular}

Fonte: relatório do PQA (ICF-KAISER e LOGOS 1999).

As tipologias de uso do solo foram as principais ferramentas utilizadas no PQA (ICF-KAISER e LOGOS 1999) para a identificação das vulnerabilidades ambientais da bacia. Selecionou-se, de um lado, os usos compatíveis com os princípios de preservação e conservação dos recursos hídricos apresentados no item "Formações Vegetais existentes na bacia", e de outro, os usos impactantes, em sua maioria associados à ocupação antrópica, que conferem às sub-bacias um comportamento de maior ou menor estabilidade frente aos processos naturais ou acelerados do meio físico. O desencadeamento desses processos foi identificado como o responsável por grande parcela da degradação dos corpos d'água, em especial os assoreamentos e adversidades aos ecossistemas aquáticos e ribeirinhos. 


\section{As fontes de degradação na bacia}

A degradação ambiental na bacia do Paraíba do Sul no trecho paulista estudado no PQA (ICF-KAISER e LOGOS 1999) apresenta várias origens, podendo-se afirmar que todas induzidas ou aceleradas pela ação antrópica.

Dentre as principais fontes de degradação identificadas na bacia destacam-se:

- a aceleração de processos erosivos por desmatamentos, cortes, aterros, exposição de solos;

- incremento aos processos de assoreamento pela contribuição dos processos de erosão não controlados;

- poluição de corpos d' água por lançamento de efluentes não tratados de origem doméstica e industrial;

- poluição de corpos d'água por carga difusa;

- intensa degradação de leito e margens fluviais do Paraíba pela extração de areia;

- inundações de áreas ribeirinhas com ocupações indevidas;

- disposição final de resíduos sólidos em condições inadequadas.

\section{Usos antrópicos em ambientes rurais na bacia}

$\mathrm{Na}$ bacia do Paraíba do Sul os usos antrópicos têm sido, desde o século passado com a cultura cafeeira e até hoje com a pecuária leiteira, responsável pelos diversos níveis de degradação dos solos hoje encontrado. A exploração dos solos até exaurílos, sem a preocupação com a conservação principalmente física e com a fertilidade, levou à atual dificuldade de recomposição da cobertura vegetal, mesmo gramínea de boa qualidade ou cultivos agrícolas e florestas naturais.

A baixa fertilidade dos solos, resultante de mau uso, associada à topografia acidentada que predomina em grande parte da bacia, são impeditivos à ocupação rural diversificada e rentável, direcionando a tendência da ocupação rural mais para a pastagem (uso predominante hoje, correspondendo a $53,42 \%$ do total) e para o 
recobrimento florestal (reflorestamento recobre cerca de $5 \%$; matas 17,35\% e capoeiras $13,43 \%)$.

A pastagem na bacia do Paraíba do Sul, no trecho paulista, é extensiva ou semi-extensiva, apresentando duas situações:

- na encosta: os pastos são de baixa qualidade, em função dos solos terem perdido a fertilidade, e de baixa capacidade produtiva, implicando na exposição dos solos aos processos erosivos. É agravado na concentração do pisoteio do gado, nas trilhas dos animais, inclusive formando terracetes nas encostas.

- na várzea: não constituem problema. Do ponto de vista agronômico, é uma subutilização da várzea, área nobre, mas não é inadequada. Há a concorrência com outros usos, como a expansão urbana nos terrenos mais secos, e com a mineração de areia.

A agricultura praticada no trecho paulista da bacia é, atualmente, em pequena escala e muito pouco expressiva em termos comerciais e território ocupado, sendo também praticamente de caráter temporário. Corresponde a $1,42 \%$ do território, somando-se a agricultura de várzea (mais representativa) e a agricultura praticada nas encostas. Apresenta diferentes comportamentos nas duas situações em que ocorre:

- na encosta: basicamente representada pelas culturas anuais / temporárias, que estão associadas a áreas pequenas ou de subsistência, e muitas vezes associadas à reforma de pastagens. Não é preparada anualmente, uma vez que faz rodízio com pastagem, portanto não constitui fator de degradação constante. São itinerantes, em função de doenças e pragas nas lavouras, e também pela degradação principalmente em função de irrigação mal conduzida, em especial nas lavouras de tomate (irrigação por sulcos). Os principais produtos da agricultura praticada na bacia são o tomate, com problemas pontuais (principalmente em Paraibuna e São Luis do Paraitinga), e em escala mais reduzida o café, a fruticultura e a cana (que alimenta o gado e os alambiques da região). Em termos de tendência, e do 
ponto de vista conservacionista, a cana não é problema nem deverá vir a ser, pois nunca chegará a ser monocultura na região.

- na várzea: nesse ambiente a agricultura apresenta como principais problemas ambientais os riscos de contaminação direta de corpos hídricos por fertilizantes e agrotóxicos; e significativa contribuição de sólidos em suspensão para os cursos d'água a jusante em função do preparo do solo para o plantio na várzea, onde deve-se inundar o solo (popularmente chamado de "fazer barro") para obter o nivelamento exigido para esse tipo de irrigação, por inundação. Os principais produtos aí cultivados são o arroz, o milho e os hortigranjeiros.

\section{Degradação por atividades de mineração}

A degradação ambiental pelo extrativismo mineral na bacia do Paraíba do Sul encontra na extração de areia sua maior expressão, embora a potencialidade para outros bens minerais, como a bauxita e o granito ornamental, não seja desprezível no Vale.

O potencial de areia, relativo aos depósitos aluvionares recentes na planície fluvial do rio Paraíba, principalmente em seu trecho meandrante entre Jacareí e Cachoeira Paulista, é ainda bastante alto, com inúmeros pontos de extração existentes, concentrados entre Jacareí e Pindamonhangaba.

Segundo estudos de órgãos atuantes na região, o trecho estudado (de Jacareí a Queluz) apresentou no ano-base de 1.996 um total de 119 portos de areia em atividade, sendo 89 com extração em cava, 32 com dragagem no rio e $6 \mathrm{com}$ desmonte hidráulico.

O método mais utilizado na bacia é a mineração por escavação, em função da conhecida escassez do material no leito do rio e da facilidade de operação, sendo responsável por cerca de $80 \%$ da produção na região. Os impactos mais evidentes são a perda de solo, a erosão do material de decapagem quando estocados de forma inadequada, a erosão da frente da lavra e o abandono de grandes cavas ao término da atividade, impedindo o uso futuro do solo e gerando criadouros de vetores de doenças e incômodos à população. 


\section{Relatório Zero e Plano de Bacia}

Conforme estabelece a lei Estadual n. ${ }^{\circ} 7.663$, (SÃO PAULO 1991) cabe ao comitê de bacia "aprovar a proposta do plano de utilização, conservação, proteção e recuperação dos recursos hídricos da bacia hidrográfica". Para tanto o CORHI Comitê Coordenador do Plano Estadual de Recursos Hídricos, preparou proposta com métodos para elaboração do denominado "Relatório Zero", documento este que serviu de base para efetuar os Planos das Bacias Hidrográficas do Estado de São Paulo (2000 - 2003).

O "Relatório Zero" - Primeiro Relatório de Situação dos Recursos Hídricos da UGRHI-2 (Paraíba do Sul), realizado pela CPTI (2000), que consiste em identificar e viabilizar a implantação de ações, estruturais ou não, capazes de ajustar as características da água disponível no local de utilização àquelas exigidas por cada um dos usos. Cabe ressaltar que este relatório constitui o primeiro de uma série de relatórios de situação, que deveriam ser efetuados anualmente, segundo a legislação vigente.

Os estudos realizados no relatório do PQA, realizado pelo Consórcio ICFKAISER e LOGOS (1999), foram refinados para o Relatório Zero, a partir dos cenários priorizados.

Cabe aqui ressaltar o que foi enfatizado pela CPTI (2000) durante a elaboração do relatório: "muitos dos dados disponibilizados no PQA já apresentavam-se desatualizados e/ou em escala incompatível com o levantamento proposto, necessitando a geração de novos dados, além da adequação e melhoria das informações existentes para os próximos relatórios de situação, além da proposição urgente de atualização da base de mapas existente, contemplando análise por sensoriamento remoto e trabalhos de campo. Os dados coletados, basicamente secundários e muitas vezes não consistidos nos bancos de origem, permitiram uma primeira avaliação da situação dos recursos hídricos e devem constituir o ponto de partida para a implantação de um sistema de informação necessário ao gerenciamento dos recursos hídricos da bacia”. 
Ou seja, percebe-se que a cada novo relatório, mantém-se a indisponibilidade de base de dados digital atualizada, o que pouparia tempo e recursos significativos aos órgãos de gestão e usuários da bacia.

Para efetivação dos trabalhos do Relatório Zero referentes à UGRHI-2, foi necessária a divisão em unidades de análise (sub-bacias) e definição das bases cartográficas a serem utilizadas. Foi decidido que, a partir de listagem fornecida pelo DAEE - Taubaté, se escolhessem as sub-bacias a serem priorizadas no posterior Plano de Bacia da UGRHI-2, através de métodos já contemplados no Primeiro Relatório Parcial de Andamento do Plano de Bacia. Dessa maneira, selecionaram-se 139 sub-bacias de afluentes diretos do rio Paraíba do Sul em território paulista, mais um conjunto de sub-bacias que afluem no referido rio no Estado do Rio de Janeiro. Estas 140 sub-bacias são listadas na Tabela do 1.

No Plano de Bacia da UGRHI-2, CPTI (2001) foram priorizadas 11 das 139 sub-bacias de afluentes diretos do Rio Paraíba do Sul em território paulista.

Após o conhecimento na escala 1:50.000 dos recursos hídricos e de seus principais tipos de uso e necessidades, do uso e ocupação do solo, optou-se por elaborar o Plano de Bacia com o objetivo de se estabelecer ações que conduzissem à adequada utilização dos recursos hídricos pelos seus respectivos usos. As ações de intervenção ajustam as disponibilidades hídricas às demandas e as ações de gestão viabilizam a sua implementação. O Planejamento dessas ações levou em conta, por razões de eficiência e eficácia, atingir algumas metas estabelecidas com base em critérios que priorizaram a utilização das águas dos afluentes diretos do Rio Paraíba do Sul.

\section{Avaliação do rio Paraíba do Sul - FUNDUNESP}

Para o trecho do Paraíba do Sul em São José dos Campos foi realizado pela UNESP (FUNDUNESP 2003), avaliação mensal de qualidade das águas, sedimentos e fauna e flora às suas margens, no período de Abril/2002 a Fevereiro/2003. A localização dos pontos de monitoramento de qualidade das águas da UNESP e da CETESB em relação aos cursos d'águas principais é indicada na figura 13 que 
apresenta a sobreposição dos Planos de Informações do rio Paraíba do Sul e reservatórios e dos pontos de amostragem elaborados no SPRING.

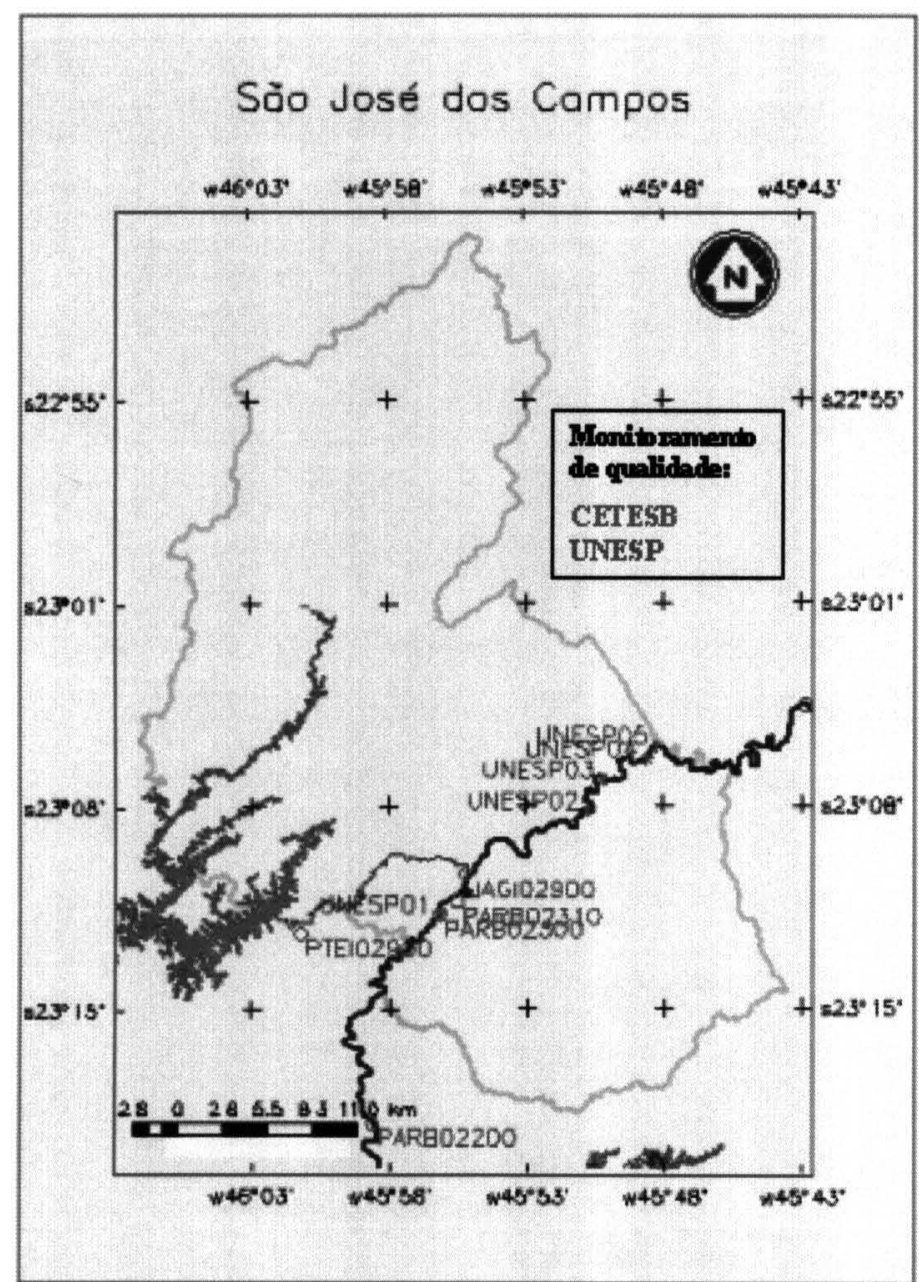

Figura 13 - Pontos de amostragem de qualidade da CETESB e da UNESP em São José dos Campos.

São José dos Campos está situada à leste do Estado de São Paulo, na zona fisiográfica do médio Paraíba, possui uma área total de $1102 \mathrm{~km}^{2}$, sendo que em torno de $80 \%$ corresponde a área rural e constitui-se no mais importante dos municípios situados na bacia do Paraíba do Sul.

A sede municipal tem as seguintes coordenadas geográficas:

- $23^{\circ} 13^{\prime} 53$ "- Latitude Sul;

- 4551’21” - Longitude Oeste de Greenwich. 
A figura 14 a seguir mostra Imagem Landsat de Agosto/2001, sintética da composição das bandas 3, 4 e 5, com recorte sobre o município de São José dos Campos.

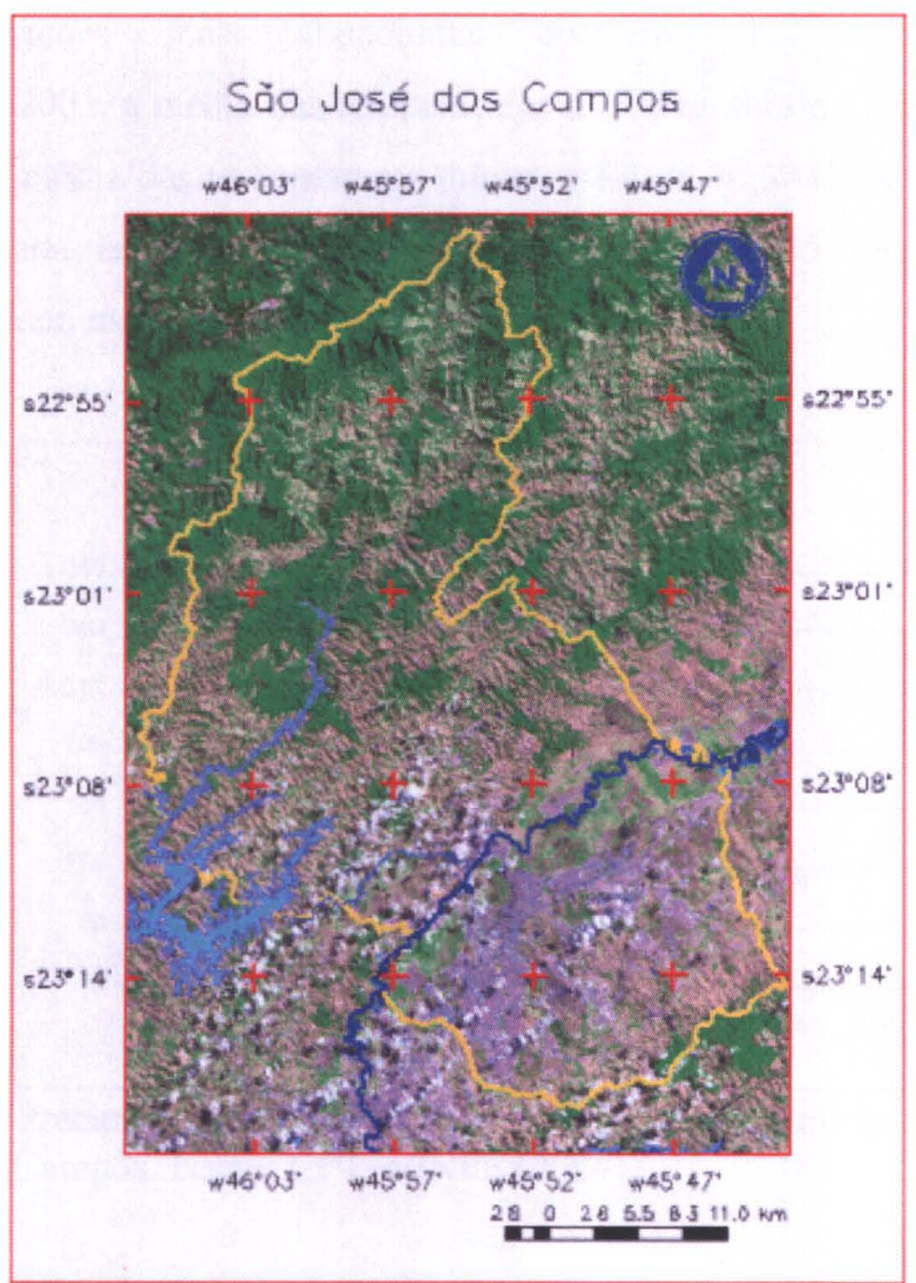

Figura 14 - Imagem de São José dos Campos. Sintética do satélite Landsat, de Agosto/2001.

O município é constituído por dois sub-distritos, a sede e o de Santana do Parnaíba e os distritos de Eugênio de Melo e São Francisco Xavier.

A área do município de São José dos Campos, conforme descrita na tabela 4 a seguir, fica totalmente inserida na bacia do Paraíba do Sul.

Tabela 4 - Área urbana e rural do município de São José dos Campos

\begin{tabular}{l|l|l}
\hline SITUACAO* & AREA $\mathrm{km} 2$ & 0 \\
\hline URBANA** & 294,13 & 26,69 \\
\hline EXPANSÃO URBANA & 126,24 & 11,46 \\
\hline RURAL & 681,66 & 61,85 \\
TOTAL & $1,102,20$ & 100,00
\end{tabular}

Fonte: Pref. Municipal de São José dos Campos 
O clima de São José dos Campos, na classificação de Koeppen é de Cwa (Mesotérmico Úmido com estação seca no inverno). As precipitações mais abundantes ocorrem de dezembro a março. No verão de 2003 , a média das temperaturas máximas foi de $26,5^{\circ} \mathrm{C}$, enquanto que no inverno a média das temperaturas mínimas foi de $16,3^{\circ} \mathrm{C}$. A temperatura média anual alcançada em 2003 foi de $21,4^{\circ}$ C. A Figura 15 insere a precipitação pluviométrica no município de São José dos Campos, SP.

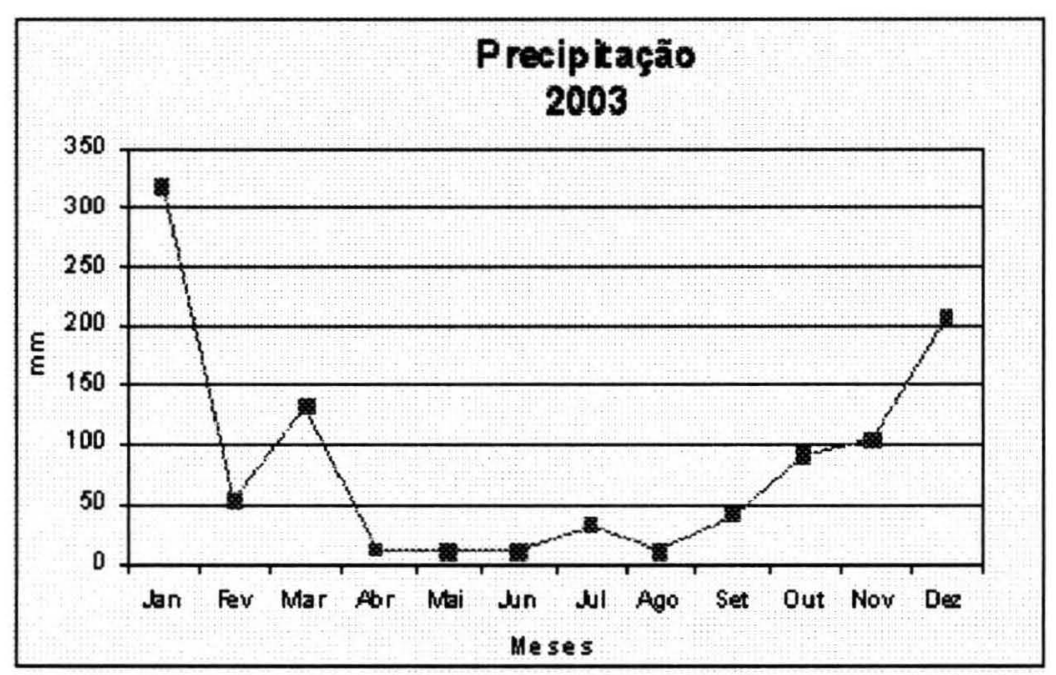

Figura 15 - Precipitação ao longo do ano de 2003 no município de São José dos Campos. Fonte: CPTec/INPE (2004).

O Rio Paraíba do Sul no trecho em que corta o município caracteriza-se por possuir na sua margem esquerda afluentes mais significativos, onde se destaca o Rio Jaguari e o Rio Buquira. Já na margem direita ocorre maior número de tributários, que apesar de não apresentarem volumes significativos de água, cumprem importante papel no sistema de drenagem superficial porque cruzam toda a malha urbana em direção ao rio Paraíba do Sul, entre os quais destaca-se o Rio Comprido, Ribeirão Vidoca, Ribeirão dos Putins ou Cambuí, Córrego Lavapés, Rio Alambari e o Rio Pararangaba.

O município possui mais de 300 mananciais e vertentes que formam rios, riachos, ribeirões, córregos, arroios e aguadas de cabeceira. 


\subsubsection{Região do estudo de caso}

A região de estudo é definida, através da aplicação da metodologia, pelo trecho do rio Paraíba do Sul compreendido pelos pontos PARB 02310 e 02400 da rede de monitoramento de qualidade das águas interiores do estado de São Paulo, que se estende por $42,7 \mathrm{~km}$ de curso extremamente sinuoso, desenvolvido em ampla e contínua várzea cuja largura excede a sua faixa de meandros. As características dos pontos são:

- Ponto PARB02310: Localizado no rio Paraíba, na captação de São Jose dos Campos, cujas coordenadas geográficas são:

Lat: 23o 11' 16" Long: 45o 55'04"

UTM: 7.434.961,758844 m N 405.815,292224 m E

- Ponto PARB02400: Localizado no rio Paraíba na ponte da rua do Porto, no trecho que liga Caçapava ao bairro Menino Jesus, cujas coordenadas geográficas são:

Lat: 23o 04' 54' 'Long: 450 42' 40"

UTM: 7.447.229,079111 m N 427.163,834378 m E

Uma vez escolhido o trecho de avaliação do rio Paraíba do Sul, que corta as zonas urbanas dos municípios de São José dos Campos e Caçapava, é definida a região de estudo através da área de contribuição das sub-bacias dos afluentes a este trecho do rio.

Dessa forma a região de estudo envolve além de parte dos municípios de São José dos Campos e Caçapava, toda a área do município de Monteiro Lobato, conforme pode-se observar na figura 16 a seguir.

Os principais centros urbanos localizados na área de influência do trecho estudado são: São José dos Campos, Jacareí, Taubaté e Caçapava, que juntos representam mais de $50 \%$ da população da bacia paulista do Paraíba do Sul. 


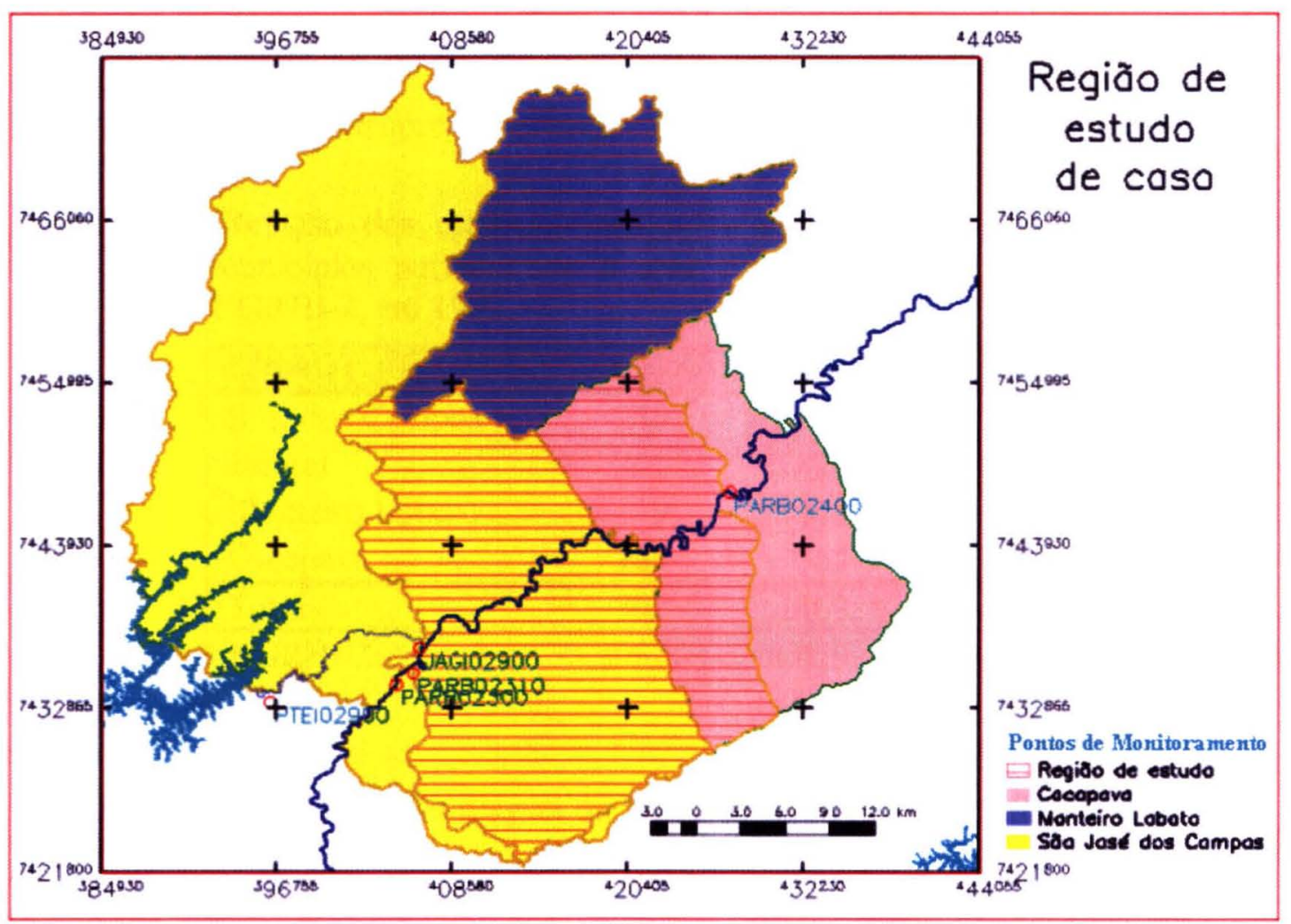

Figura 16 - Municípios abrangidos pela região do estudo de caso.

A população dos municípios que apresentam influência direta sobre a qualidade da água da região de estudo teve sua projeção calculada pela CPTI (2001) no Plano de Bacia, conforme indicada na tabela 5 a seguir.

Tabela 5 - Projeção da população para os municípios pertencentes à área de influência da região estudada e UGRHI-2.

\begin{tabular}{lrrr}
\multicolumn{1}{c}{ Cidades } & \multicolumn{3}{c}{ Projeção demográfica } \\
& $\mathbf{1 9 9 9}$ & $\mathbf{2 0 0 3}$ & $\mathbf{2 0 1 0}$ \\
\hline S. J. dos Campos & 513.196 & 552.318 & 628.091 \\
Jacareí & 169.851 & 172.784 & 178.032 \\
Monteiro Lobato & 3.310 & 3.294 & 3.295 \\
Caçapava & 69.216 & 70.757 & 735.309 \\
\hline UGRHI-2 & 1.685 .924 & 1.775 .881 & 1.951 .870
\end{tabular}

Fonte: CPTI 2001. 
A bacia hidrográfica e os municípios em questão apresentam um perfil predominantemente urbano, em 1999 a taxa de urbanização era de 91,0\%, com repercussão similar no perfil das atividades rurais e urbanas, conforme pode-se observar no quadro de empregos apresentado na tabela 6.

Tabela 6 - Relação dos estabelecimentos rurais e industriais e empregos nos municípios pertencentes à área de influência da região estudada e UGRHI-2, em 1998.

\begin{tabular}{|c|c|c|c|c|}
\hline Clabrites & 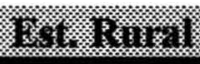 & 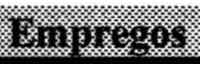 & Intivistivas & 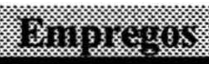 \\
\hline S. J. dos Campos & 240 & 649 & 963 & 43.057 \\
\hline Jacareí & 261 & 829 & 331 & 11.860 \\
\hline Monteiro Lobato & 79 & 118 & 7 & 440 \\
\hline Caçapava & 122 & 367 & 140 & 4.852 \\
\hline Total & 702 & 1963 & 1441 & 60209 \\
\hline UGRHI-2 & 3062 & 8.479 & 3.436 & 104.508 \\
\hline
\end{tabular}

\section{Enquadramento dos corpos d'água da UGRHI-2, na região estudada}

O enquadramento dos corpos d'água, conforme Decreto Estadual $\mathrm{n}^{\circ} 10.755$ (SÃO PAULO 1976), em função do uso é o descrito a seguir:

\section{CLASSE 1:}

- rio Buquira ou Ferrão e todos os seus afluentes até o córrego Bengala, inclusive,

- rio Jaguari e todos os seus afluentes, exceto o ribeirão Araquara, até a sua barragem no Município de Igaratá;

\section{CLASSE 2:}

- Pertence à Classe 2 todos os corpos d'água, exceto os alhures classificados.

CLASSE 3: não há 


\section{CLASSE 4:}

Pertencem à Classe 4 os seguintes corpos d'água, excluídos os respectivos afluentes e formadores, salvo quando expressamente indicados nas alíneas.

- córrego Serimbura até sua confluência com o ribeirão Vidoca, no Município de São José dos Campos;

- ribeirão Lava-Pés, afluente do rio Paraíba, no Município de São José dos Campos;

- ribeirão Manuel Lito desde a confluência com o córrego Tijuco até a confluência com o rio Paraíba no município de São Jose dos Campos;

- ribeirão dos Putins até a confluência com o rio Paraíba, no município de São José dos Campos.

- ribeirão Vidoca desde a confluência com o córrego as Águas Claras até a confluência com o rio Paraíba.

\subsection{Materiais}

Faz parte do objetivo deste trabalho a utilização ao máximo de informações de acesso público, ou seja, facilmente atualizáveis, complementando-as ao mínimo com as necessárias aos modelos de estimação de carga poluidora e de representação da qualidade da água, integrado-as no ambiente de SIG.

Para a realização deste trabalho, desenvolvido com dados da bacia do Paraíba do Sul, foram utilizados os seguintes materiais:

Base de dados digitais:

- dados em formato digital ("dwg”) georreferenciados pela CPTI (2000) para o Comitê de Bacia Hidrográfica do Paraíba do Sul CBH-PS contendo: divisa de municípios, rede hidrográfica, limite de sub-bacias, baseado nas cartas do Instituto Brasileiro de Geografia e Estatística (IBGE), escala 1:250.000, Meridiano Central $-\mathrm{MC}=45^{\circ} \mathrm{W}$, projeção Universal Transversa de Mercator - UTM, datum horizontal: Córrego Alegre/MG, datum vertical: Imbituba/SC; 
- imagem TM-LANDSAT, bandas 3, 4 e 5, 07/06/2002 e 11/06/2002 cenas: 219/76 e 218/76, cedidas pelo INPE;

- imagem CBERS_2_CCD1XS_20040130_153_126_BAND 2, 3 e 4, de 02/03/2004;

- base de Dados da Prefeitura Municipal de São José dos Campos CD_Room CIDADE VIVA, contendo: imagem Landsat 18/08/2001 e SPOT 02/09/1997 mosaico, Usos da terra: área urbana, cultura, corpo d'água, mata, capoeira, nuvem, pastagem, reflorestamento, a partir de Imagem LandSat 15/08/2001, Fotografias ortorretificadas da região urbana, incluindo toda margem direita do Paraíba, referente a 1997, delimitação da área urbana e de distrito, Drenagem municipal (IBGE) escala 1:50.000, Modelo de Elevação Digital (DEM) do município, de $20 \mathrm{~m}$ em $20 \mathrm{~m}$, referente ao município inteiro (curvas nível), Rede viária a partir de imagem de satélite (atualizada), Carta Geotécnica 1:50000, Zoneamento legal (Área urbanizada 1:2000, Área municipal 1:50000), quadras: linhas/texto 1:2000 (2000), obtidas das ortofotos, Setor sócio econômico (zonas/setor planejamento/setor área, perímetro, não consta população de 2000), bairros e localidades, Zonas especiais de proteção urbana (macrozona).

- cartas topográficas do IBGE de Paraibuna, Santa Branca, Guararema, Jacareí, Igaratá e São José dos Campos na escala 1:50.000, projeção UTM, Córrego Alegre.

- dados de recursos hídricos superficiais disponíveis PQA, ICF-KAISER e LOGOS (1999) no formato digital ("dwg") em especial o mapa de Uso do Solo, obtido na escala 1:100.000, a partir de foto-interpretação de imagens de satélite de 1993 (GEROE, 1995) e de 1997 (atualização 1998) e a delimitação da bacia paulista do Paraíba do Sul.

Dados qualitativos e quantitativos da bacia Paulista do Paraíba do Sul:

- dados de monitoramento da qualidade das águas, obtidos do Relatório de Qualidade das Águas Interiores do Estado de São Paulo de 2003 e 2004 da CETESB; 
- informações sobre a bacia do Paraíba do Sul obtidas no Relatório de Situação dos Recursos Hídricos da Unidade de Gerenciamento dos Recursos Hídricos Paraíba do Sul, UGRHI - 2, elaborado pela CPTI (2000);

- informações sobre a bacia do Paraíba do Sul obtidas no Plano de Bacia da UGRHI 1 - Serra da Mantiqueira e da UGRHI 2 - Paraíba do Sul, elaborado pela CPTI.(2001);

- dados Pluviométricos e Fluviométricos, obtidos da Agência Nacional de Águas ANA, através do site http://www.ana.gov.br, no Sistema de Informações Hidrológicas versão Web 3.0 e da Estação Meteorológica da Petrobras - REVAP;

- dados de vazão afluente e defluente referentes aos aproveitamentos hídricos da bacia do Paraíba do Sul, disponíveis na internet pela Operadora Nacional do Sistema Elétrico - ONS disponível em: http://www.ons.org.br;

- identificação dos afluentes diretos do Paraíba do Sul e das sub bacias dos afluentes diretos priorizadas pelo Comitê de Bacias, obtidos de CPTI (2000), contendo: áreas das sub-bacias, precipitações extraída de isoietas por subbacias, outorgas de uso da água, entre outras informações;

- situação do tratamento dos esgotos gerados: SABESP (população em subbacias) e SAEE (estudo de população em sub-bacias).

Softwares utilizados:

- software SPRING - Sistema de Processamento de Informações Geográficas do INPE versão 4.1 .1 (disponível em http://www.dpi.inpe.br) e seus módulos:

○ IMPIMA: Módulo para promover a leitura e conversão de imagens;

- SCARTA: Permite a visualização dos dados gerados no SPRING e permite que os elementos necessários a elaboração de uma carta sejam inseridos e posicionados adequadamente. 


\subsection{Métodos}

O desenvolvimento de metodologia, apoiada em geotecnologias e dados publicamente disponíveis, para avaliação da situação e da evolução da qualidade das águas em termos de carga poluidora associada ao uso e ocupação/cobertura do solo, visando o auxílio na tomada de decisões no gerenciamento de recursos hídricos, foi constituída basicamente das seguintes etapas:

a) estabelecimento de base digital da região contendo: drenagem, limites das bacias, localização das informações de qualidade ambiental, fluviométricas, pluviométricas, modelo digital de elevação do terreno, uso e ocupação/cobertura do solo;

b) concepção de Banco de Dados Geográfico sobre a qualidade ambiental da região constituído de: dados de monitoramento de qualidade das águas superficiais da bacia, identificação de fontes de poluição pontuais e não pontuais, disponibilidade hídrica, dados demográficos, características econômicas e tendência de crescimento, ações em curso ou planejadas considerando a região de estudo, Concentração Média de Eventos de Chuva - CME de poluentes de origem difusa relacionados às atividades desenvolvidas na bacia, etc;

c) Caracterização de uso e ocupação/cobertura do solo através da classificação de imagens e/ou fotografias aéreas atualizadas ou obtida de estudo consistente ou dado disponível de instituição competente;

d) definição de Modelos Matemáticos para a simulação de cenários e tomada de decisão: Modelo hidrológico de correlação precipitação x escoamento superficial (runoff) e Modelo de cálculo do aporte de cargas difusas em função dos parâmetros de qualidade;

e) integração de modelos de simulação de cenários no ambiente com a representação do espaço geográfico.

MAIDMENT (1996) observa que a construção de modelos complexos deverá ser precedida da divisão do problema total numa série de submodelos que interagem com uma base de dados comum. Inicia-se com uma descrição em Sistema de 
Informação Geográfica - SIG da região e então através da modelagem acrescentamse detalhes adicionais à descrição regional no que diz respeito ao escoamento da água e ao transporte dos constituintes.

\subsubsection{Modelo Hidrológico}

Para a determinação das vazões foi utilizada a metodologia proposta pelo DAEE (1988, 1994), utilizada no relatório Zero CPTI (2000), face à necessidade de dados dos incrementos da sub bacias dos afluentes diretos, bem como devido à insuficiência de dados dos postos fluviométricos.

\section{Considerações teóricas}

O parâmetro hidrológico básico que traduz a disponibilidade hídrica de uma bacia hidrográfica é a vazão média de longo período (Qmédia). Este parâmetro dá uma indicação do limite superior de seu potencial hídrico aproveitável.

Por outro lado, em virtude da variabilidade do regime pluvial nas épocas de baixa pluviosidade, a disponibilidade hídrica pode ser caracterizada pela vazão mínima, como por exemplo, a $\mathrm{Q}_{7,10}$, que é a vazão mínima de sete dias consecutivos com período de retorno de 10 anos. Entende-se por período de retorno o tempo médio, em anos, que um evento (chuva) pode ser igualado ou superado pelo menos uma vez.

A metodologia adotada (DAEE 1988, 1994) estabelece que a vazão especifica média (Qesp) pode ser obtida de sua relação linear com o total médio precipitado ( $\mathrm{P}$, em mm anuais) na bacia hidrográfica, onde a e b são parâmetros da reta de regressão:

$\mathrm{Q}_{\text {esp }}=\mathrm{a}+\mathrm{b} . \mathrm{P}$

Multiplicando-se a vazão específica média pela área de drenagem da bacia em estudo, tem-se a vazão Qmédia:

$\mathrm{Q}_{\text {média }}=\mathrm{Q}_{\mathrm{esp}} \cdot \mathrm{S}$

Onde: 
$\mathrm{Q}_{\text {média }}=$ vazão média de longo período $(1 / \mathrm{s}) ;$

$Q_{\text {esp }}=$ vazão específica média plurianual $\left(1 / \mathrm{s} \cdot \mathrm{km}^{2}\right)$;

$\mathrm{S}=$ área da bacia de contribuição $\left(\mathrm{km}^{2}\right)$.

Considerando a regionalização hidrográfica para o Estado de São Paulo (DAEE, 1988, 1994), que agrupa áreas homogêneas (de A a U) com variáveis hidrológicas semelhantes (Figura 17), foram adotados valores de a e b constantes no Tabela 7 para a UGRHI-2 (área $\mathrm{H}$ ).

Tabela 7 - Parâmetros regionais a, b, XT, A e B para a UGRHI - 2

\begin{tabular}{|c|c|c|c|c|c|c|c|}
\hline $\begin{array}{c}\text { Unidade } \\
\text { hidrográfica }\end{array}$ & Região & $\mathbf{a}$ & $\mathbf{b}$ & $\mathbf{C}_{\mathbf{7}, \mathbf{m}}$ & $\mathbf{X T}$ & $\mathbf{A}$ & $\mathbf{B}$ \\
\hline UGRHI-2 & $\mathrm{H}$ & $-29,47$ & 0,0315 & 0,85 & 0,748 & 0,4951 & 0,0279 \\
\hline
\end{tabular}

Fonte: (DAEE 1988, 1994).

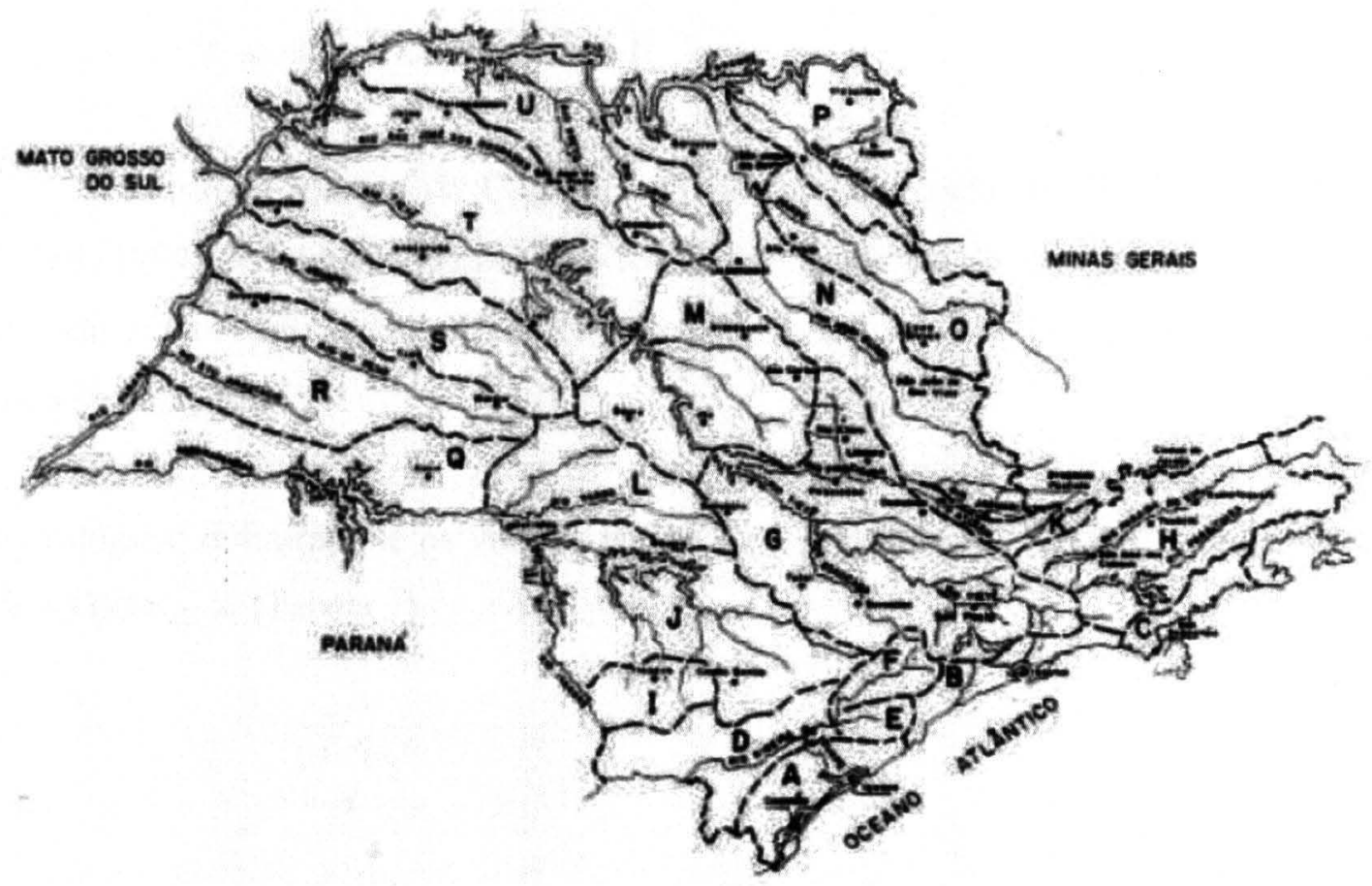

Figura 17 - Regiões hidrológicas semelhantes no Estado de São Paulo.

Fonte: (DAEE 1988, 1994).

A vazão média $\left(\mathrm{Q}_{\mathrm{média}}\right)$ assim determinada representa o limite máximo, teórico, possível de ser utilizado, mediante regularização do escoamento, e significa, na 
realidade, um valor de vazão para a área de drenagem da sub-bacia considerada. Quanto às vazões mínimas, uma solicitação freqüente refere-se àquela com sete dias de duração, cuja vantagem é sofrer menor influência de erros operacionais e intervenções humanas no curso de água, do que a vazão mínima diária e é suficientemente mais detalhada que a vazão mínima mensal. Assim, esta vazão, captada a fio d'água é utilizada com freqüência como indicador da disponibilidade hídrica natural num curso de água.

$\mathrm{O}$ cálculo de $\mathrm{Q}_{7,10}$ pode ser obtido pela equação a seguir:

$\mathrm{Q}_{7,10}=\mathrm{C}_{7, \mathrm{~m}} \cdot \mathrm{X}_{10} \cdot(\mathrm{A}+\mathrm{B}) \cdot \mathrm{Q}_{\text {média }}$

Onde:

$\mathrm{C}_{7, \mathrm{~m}}=$ razão entre a média das mínimas anuais de sete dias consecutivos;

$\left(\mathrm{Q}_{7}\right)$ e a média das mínimas anuais de um mês $\left(\mathrm{Q}_{\mathrm{m}}\right)$ [adimensional];

$\mathrm{X}_{10}=$ variável aleatória $\mathrm{X}$ para um período de retorno de 10 anos [adimensional];

$\mathrm{A}$ e B = parâmetros regionais;

$\mathrm{Q}_{\text {média }}=$ vazão média de longo período $[1 / \mathrm{s}]$.

Analisando valores de $\mathrm{C}_{7, \mathrm{~m}}$ para 88 postos no Estado de São Paulo, DAEE (1988, 1994) definiu três regiões (X, Y e Z) que aparecem delimitadas na Figura 18. Por ela, nota-se, no caso da UGRHI-2 (região $\mathrm{Z}$ ), um valor de $\mathrm{C}_{7, \mathrm{~m}}$ igual a 0,85 para toda sua extensão.

DAEE (1988,1994), através dos mesmos estudos de regionalização hidrológica, definiram-se os valores para XT, A e B para as unidades hidrográficas da UGRHI - 2. (Tabela 7). 


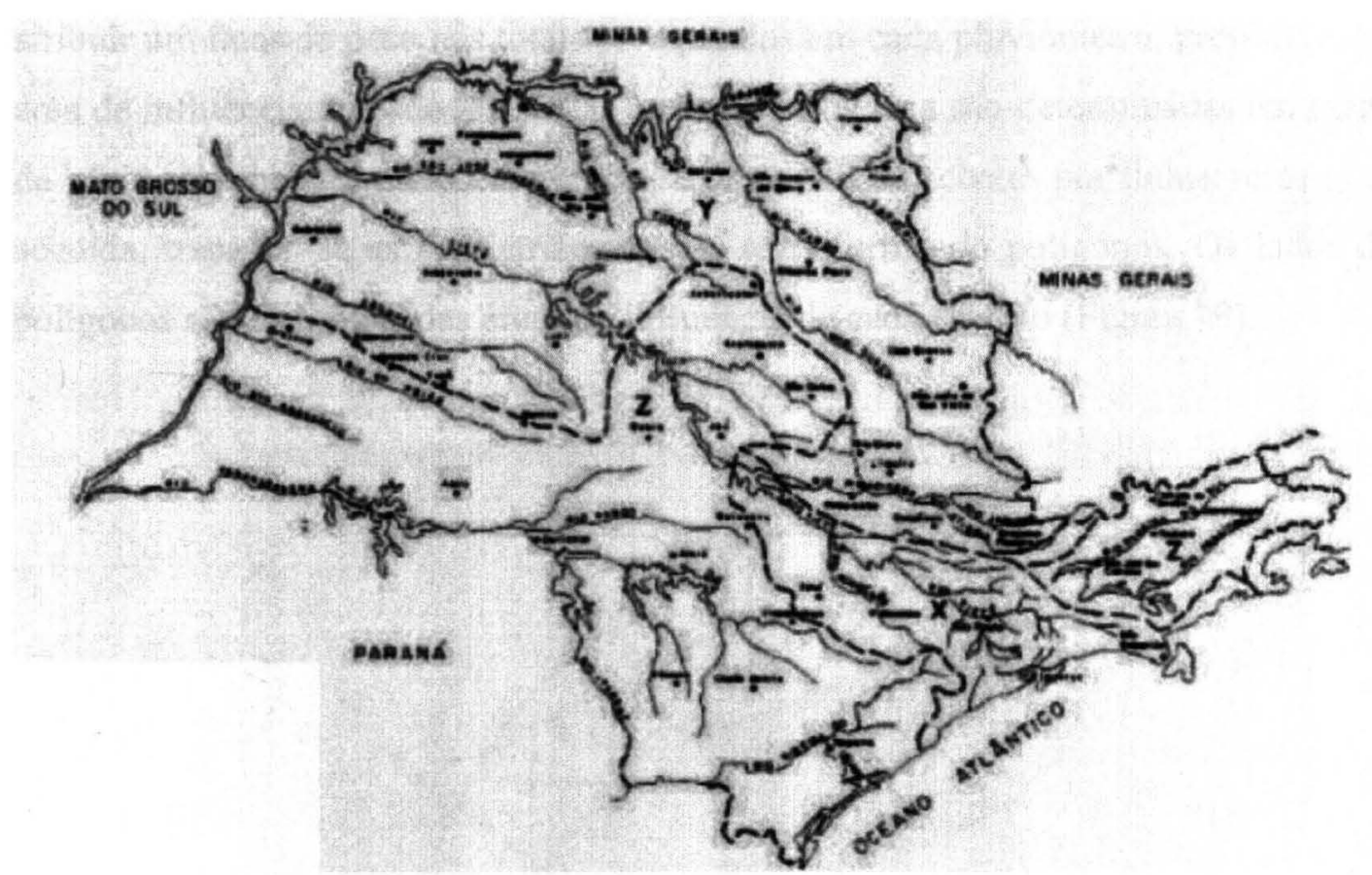

Figura 18 - Regiões hidrológicas semelhantes quanto ao parâmetro $\mathrm{C}_{7, \mathrm{~m}}$. Fonte: (DAEE 1988, 1994).

Cálculos de $\mathbf{P}, \mathbf{Q}_{\text {média }}$ e $\mathbf{Q}_{7,10}$

A altura média de precipitação em uma área específica é necessária em muitos tipos de problemas hidrogeológicos, notadamente na determinação da disponibilidade hídrica ou do balanço hídrico de uma bacia hidrográfica, cujo estudo pode ser feito com base em um temporal isolado, ou com totais de uma estação no ano, ou ainda com base em totais anuais.

DAEE $(1988,1994)$ afirma que existem três métodos principais para essa determinação: o método aritmético, o método de Thiessen e o método das isoietas.

$\mathrm{O}$ método aritmético é o mais simples: consiste em determinar-se a média aritmética entre as quantidades medidas na área. Este método só apresenta uma boa estimativa se os pluviômetros forem distribuídos uniformemente e a área for plana ou de relevo muito suave. É necessário também que a medida efetuada em cada pluviômetro individualmente varie pouco da média.

$\mathrm{O}$ método de Thiessen pode ser utilizado mesmo para uma distribuição não uniforme dos pluviômetros, e quando o terreno não é muito acidentado. Consiste em 
atribuir um fator de peso aos totais precipitados em cada pluviômetro, proporcional à área de influência de cada um. Estas áreas de influência são determinadas em mapas da bacia contendo as estações, unindo-se os postos adjacentes por linhas retas e, em seguida, traçando-se as mediatrizes dessas retas formando polígonos. Os lados dos polígonos são os limites das áreas de influência de cada estação (Figura 19).

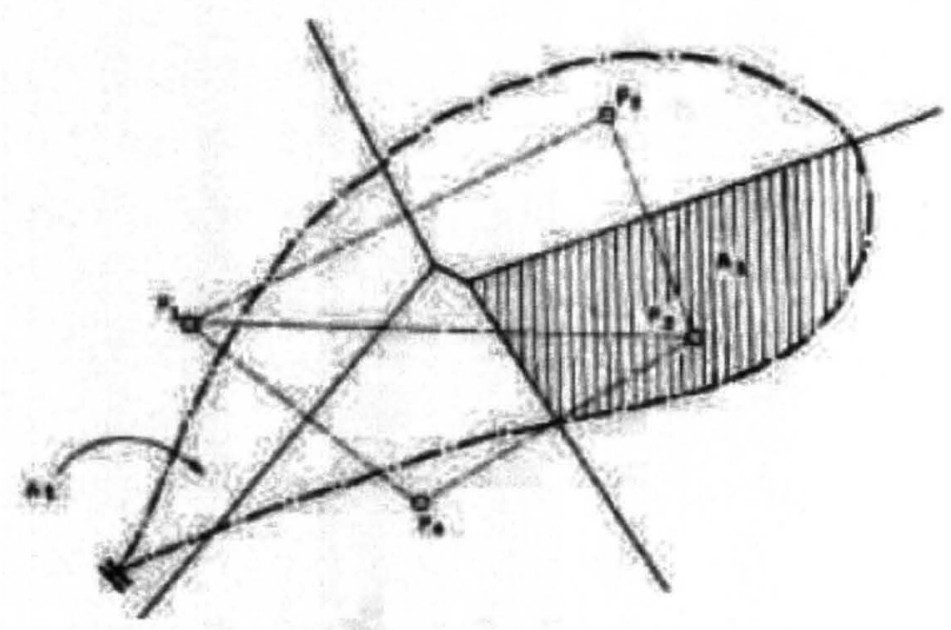

Figura 19 - Representação do método de Thiessen. Fonte: (TUCCI 1998).

A precipitação média plurianual $(\mathrm{P})$ é calculada pela média ponderada entre a precipitação Pi de cada estação e o peso a ela atribuído Ai que é a área de influência de Pi:

$$
P=\frac{\sum P_{i} A_{i}}{\sum A_{i}}
$$

$\mathrm{O}$ método de Thiessen, embora seja mais preciso que o aritmético, também apresenta limitações, pois não considera as influências orográficas, admite simplesmente uma variação linear da precipitação entre as estações e designa cada porção da área para a estação mais próxima.

Finalmente, pelo método das isoietas, em vez dos pontos isolados de precipitação, determinados pelos aparelhos de medida, utilizam-se as curvas de igual precipitação (isoietas). O traçado dessas curvas é extremamente simples e semelhante ao das curvas de nível, onde a altura da chuva substitui a cota do terreno (Figura 20). 
$\mathrm{Na}$ construção do mapa de isoietas, o hidrólogo deve considerar os efeitos orográficos, morfologia do temporal e de relevo de modo que o mapa final represente um modelo de precipitação mais real do que o que poderia ser obtido de medidas isoladas.

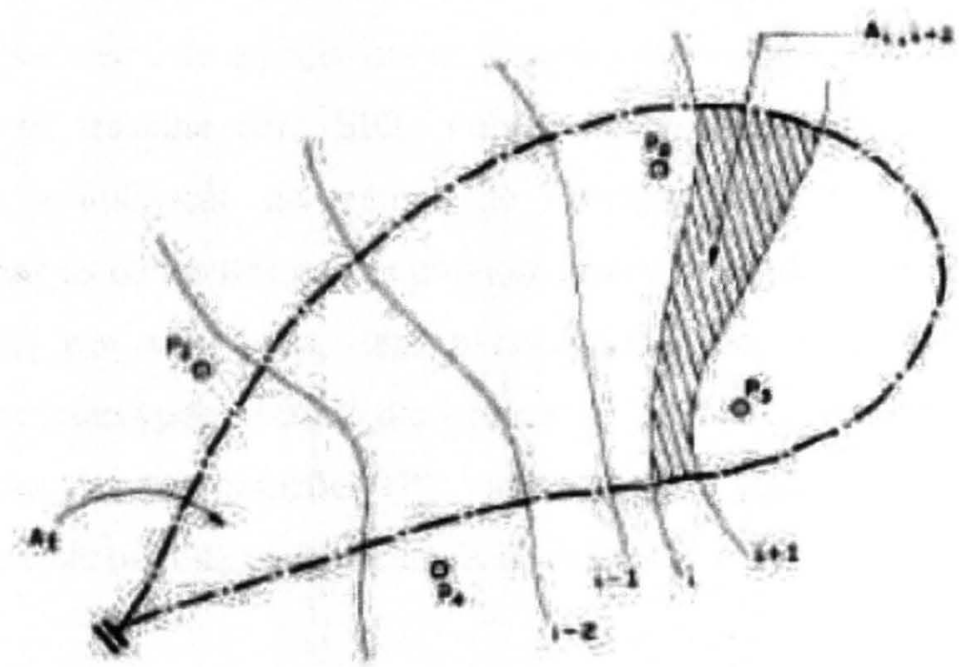

Figura 20 - Representação do método das isoietas Fonte: (TUCCI 1998).

A precipitação média sobre uma área é calculada ponderando-se a precipitação média entre isoietas sucessivas (normalmente fazendo a média dos valores de duas isoietas) pela área entre as isoietas, totalizando-se esse produto e dividindo-se pela área total, ou seja:

$$
P=\frac{\sum\left(\frac{P_{i}+P_{i+1}}{2}\right) A i}{A}
$$

Onde: $P i=$ valor das isoietas de ordem i [mm anuais];

$P i-1=$ valor das isoietas de ordem $\mathrm{i}-1$ [mm anuais];

$A i=$ área entre as duas isoietas [km2]; $A=$ área total [km2].

A precisão deste método depende altamente da habilidade do analista. Por outro lado, segundo TUCCI (1998), a precipitação pelo método das isoietas é menor em relação aos outros métodos, por proporcionar melhor distribuição das chuvas na bacia. Entretanto, o método de Thiessen revela maior praticidade, pois, para cada novo conjunto de dados acrescidos aos já existentes, pelas isoietas é preciso 
confeccionar um novo mapa de curvas de iso-precipitação, ao passo que por Thiessen, os fatores de ponderação, permanecendo os mesmos (áreas de influência dos postos), facilitam os novos cálculos.

Neste trabalho, utilizou-se o método das isoietas para os cálculos dos incrementos de vazões entre os postos, uma vez que o único mapa existente sobre regionalização hidrológica é o do DAEE $(1988,1994)$, que precisaria ser atualizado, tarefa esta que necessita de especialista da área de meteorologia.

Quando se trabalha com SIG, ambiente adequado para manipular dados espacializados, a utilização do método de Thiessen proporciona agilidade, pois bastaria atualizar os dados dos postos pluviométricos da região para dispor de dados de pluviosidade por sub bacia, sem a necessidade de manipulação prévia de especialista, necessária pelo método das isoietas.

Os valores das precipitações $(P)$, vazões $\left(Q_{\text {esp }}, Q_{\text {média }}\right.$ e $\left.Q_{7,10}\right)$ foram então estimados para cada uma das sub-bacias da UGRHI - 2 e são apresentados no anexo 4.

\subsubsection{Modelo de Poluição de Fontes Difusas}

A metodologia empregada, apropriada para a utilização de dados públicos disponíveis, consistiu de:

- definir curso d'água e/ou trecho de interesse que disponha de dados relativos à qualidade e quantidade dos recursos hídricos, bem como de base mínima de dados digitais tais como: hidrografia, clima, localização geográfica de estações de monitoramento, vazões regularizadas nos barramentos, dados sócio-econômicos, imagens de satélite, etc.;

- delimitar a área de influência através da espacialização:

- dos pontos de monitoramento de qualidade,

- dos postos pluvio e fluviométricos e dos pontos de descargas regularizadas com disponibilidades de dados, contendo séries históricas adequada, representativas das variações sazonais;

- espacialização das informações disponíveis de qualidade e vazão dos corpos d'água, necessárias ao cálculo da carga poluidora existente no corpo d'água 
principal, bem como de precipitação, associada ao transporte de poluentes de origem difusa;

- delimitar a região de estudo de caso através da área formada pelas unidades (sub-bacias) hidrográficas dos afluentes ao trecho em estudo do curso d'água principal. A delimitação das sub-bacias é realizada previamente a partir de modelo de elevação do terreno em ambiente SIG, ou através da utilização de dados digitais pré-existentes (opção adotada para o estudo de caso);

- transporte da vazão, medida no posto fluviométrico de montante mais próximo, até o início do trecho em estudo do curso d'água principal (definido por ponto de monitoramento de qualidade), através de incrementos de vazão dos afluentes calculados através do modelo de regionalização hidrológica (DAEE 1988 e 1994) a partir da área de suas bacias e de dados de precipitação obtidos das isoietas;

- cálculo da carga poluidora presente no início do trecho em estudo do curso d'água principal (vazão x concentração) e no final (definido pelo ponto de monitoramento de qualidade de jusante), determinando previamente a vazão novamente através dos incrementos definidos pelos afluentes, calculada através do modelo de regionalização hidrológica;

- identificação das cargas poluidoras de origem difusa como aquelas presentes no curso d'água principal, associadas aos parâmetros considerados conservativos e que apresentam evolução ao longo do curso d'água associada à períodos de elevação na intensidade pluviométrica;

- aquisição de imagem para a classificação sobre o uso e ocupação/cobertura do solo na área de estudo ou obtenção desta informação previamente elaborada, compatível com os dados de qualidade e de vazão;

- utilização de ferramenta de SIG para o cruzamento de planos de informações sobre uso e ocupação/cobertura do solo da área de interesse com o de delimitação das sub-bacias, gerando a informação sobre uso e ocupação/cobertura do solo por sub-bacia;

- determinação do incremento de vazão no trecho de interesse, associado a cada tipo de uso e ocupação/cobertura do solo. 
- avaliação da evolução das cargas poluidoras no trecho de interesse e da associação aos períodos de maior intensidade pluviométrica, identificando o diferencial como de origem difusa;

- estimativa da Concentração Esperada Média de poluentes decorrente do uso do solo, através dos dados de carga poluidora atribuída como de origem difusa e parcela de vazão associada a cada uso e ocupação/cobertura do solo.

A utilização das informações se dá em ambiente apropriado ao manuseio de dados associados ao espaço que são os Sistemas de Informações Geográficas - SIG. Neste trabalho utilizou-se o software SPRING do INPE, acessível publicamente.

A delimitação das sub-bacias foi utilizada tanto para o cálculo dos incrementos de vazão ao corpo d'água principal como para o cálculo do aporte de carga poluidora difusa associada ao uso e ocupação/cobertura do solo.

\section{Base de Dados Digital}

Foi criado um Banco de Dados único no software SPRING versão 4.1.1 do INPE, disponível gratuitamente no site deste órgão, sendo elaborado um "projeto" englobando toda a bacia hidrográfica paulista do rio Paraíba do Sul, referente à área de influência e outro envolvendo apenas as sub bacias do trecho de interesse (entre os postos de monitoramento de qualidade) compreendidas pelo município Monteiro Lobato, parte de São José dos Campos e de Caçapava.

$\mathrm{Na}$ escolha do trecho de interesse, que deve levar em conta a disponibilidade de base digital e a evolução de carga poluidora, foi necessária a utilização de informações referentes a outros trechos da bacia do Paraíba do Sul, principalmente de montante, uma vez que elas têm repercussões sobre a área de interesse em se tratando de bacia hidrográfica.

A área de interesse foi então delimitada pelas condições de contorno disponíveis, no caso basicamente dados de vazão e de qualidade dos corpos d'água, além de dados digitais de uso e ocupação/cobertura do solo.

A base digital deste banco de dados referente ao "projeto" definido pela bacia paulista do Paraíba do Sul foi formada através da importação dos mapas digitalizados 
no formato digital ("dwg") pela CPTI (2000 e 2001) e pela ICF-KAISER e LOGOS (1999).

A base digital referente à parcela do "projeto" definido pela área das sub-bacias situadas no município de São José dos Campos foi obtida de dados digitais já no formato do próprio SPRING ("grib"), sendo complementada com dados ("Planos de Informação" ou layers), obtidos da PM de São José dos Campos (CD-ROOM Cidade Viva) referentes às sub-bacias dos afluentes diretos à margem direita do Paraíba do Sul, em escala 1:60.000 projeção UTM/Córrego Alegre.

Os dados digitais importados para o SPRING, principalmente aqueles originalmente no formato "dwg", foram corrigidos e ajustados (quebras, junções, complementações, concatenizações de linhas, poligonalizações e associações a classes - nomenclatura, etc.) antes de serem utilizados na geração de novos dados.

A cenas 218 e 219/76 de imagem do satélite LandSat de Junho/2002, referentes à bacia paulista do Paraíba do Sul foram recortadas no aplicativo IMPIMA do INPE, limitando-se ao trecho de interesse, formando-se um mosaico da bacia do Paraíba do Sul, já no SPRING, onde também foi realizado o registro das imagens.

Apesar da disponibilidade de informação sobre uso e ocupação/cobertura do solo do município de São José dos Campos baseada em imagem do LandSat de $15 / 08 / 2001$, inclusive no formato do SPRING, foi utilizado o mapa de uso e ocupação/cobertura do solo da bacia do Paraíba do Sul, obtido de dado digital no formato "dwg" de ICF-KAISER e LOGOS (1999) e importado para o SPRING para cada classe de uso, sendo os vetores (linhas) devidamente corrigidos e ajustados (quebras, junções, complementações, concatenizações de linhas e poligonalizações), feita a associação à sua classe, para então compor o mosaico que forma o Plano de Informação de uso e ocupação/cobertura do solo da bacia do Paraíba do Sul. Isto se deu em virtude da definição dos limites da região de interesse englobar as sub-bacias dos afluentes ao curso d'água principal no trecho estudado, incorporando áreas que não respeitam os limites do município de São José dos Campos. 


\section{Banco de Dados}

Além dos dados "primários", que formam a base digital, obtida de informações disponíveis publicamente, o banco de dados da bacia é formado por metadados (como os resultantes de cruzamento de planos de informações no SIG), ou seja, pela manipulação dos dados primários, acrescidos de outras informações obtidas não necessariamente no formato digital, como por exemplo, os dados das estações de monitoramento.

\section{Imagem}

As imagens ou fotografias aéreas são utilizadas para visualização e para a classificação sobre o uso e ocupação/cobertura do solo.

Para a obtenção dos Planos de Informações - PI de uso e ocupação/cobertura do solo por sub bacias dos afluentes diretos ao Paraíba do Sul, tanto para a bacia paulista como para o trecho de interesse, foi realizado o cruzamento dos Planos de Informações (layers) referentes a uso e ocupação/cobertura do solo com os Planos de Informações de delimitação das sub bacias. O cruzamento, realizado com fator de ajuste de $10 \mathrm{~m}$ e admitindo o menor polígono com $10.000 \mathrm{~m}^{2}$ (1 ha), gerou Plano de Informação do tipo Cadastral, do qual foi exportada tabela no formato de planilha Excell para posterior manipulação. Também foi gerado Plano de Informação do tipo Temático, através de agrupamento no PI Cadastral no que diz respeito ao uso/cobertura do solo, por questão de visualização. 


\section{RESULTADOS E DISCUSSÃO}

Para desenvolver e testar a metodologia foi escolhida a bacia paulista do Paraíba do Sul, sendo utilizado o trecho do rio, delimitado por dois pontos de monitoramento de qualidade da água da CETESB, que engloba o município de São José dos Campos, em função da disponibilidade de dados e da condição de qualidade da água.

Portanto o rio Paraíba do Sul foi escolhido como corpo d'água principal para avaliação de carga de origem difusa por dispor de rede de monitoramento de qualidade da água (CETESB 2003 e 2004) e sua bacia dispor de base digital mínima elaboradas nos estudos do PQA (ICF-KAISER E LOGOS 1999) e Relatório Zero Plano de Bacia (CPTI 2000), para o desenvolvimento de trabalhos em ambiente de Sistema de Informação Geográfica - SIG.

Visando o aproveitamento de dados atualizados e no formato digital, além do uso e ocupação/cobertura do solo, buscou-se restringir a área de estudo a uma subbacia de afluente direto do rio Paraíba do Sul. Inicialmente vislumbrou-se trabalhar com a bacia do rio Una para a qual foi contratado, recentemente pelo Comitê de Bacias, estudo prevendo a formulação de base de dados. No entanto, neste projeto, não foi previsto o levantamento de informações sobre qualidade da água do rio, até então inexistente.

\section{Área de Estudo}

Na bacia do Paraíba do Sul identificou-se a região de influência do município de São José dos Campos (figura 21), onde a prefeitura municipal já dispunha de base de dados digitais atuais e em cujo trecho do rio Paraíba do Sul foi realizado estudo recente pela FUNDUNESP (2003). Foi então concebido um Banco de Dados preliminar, mais amplo, levando em conta as informações da bacia do Paraíba do Sul, além das específicas da região municipal, sobre condições hidrológicas, pluviométricas e de qualidade de água, disponíveis pelas instituições competentes. 


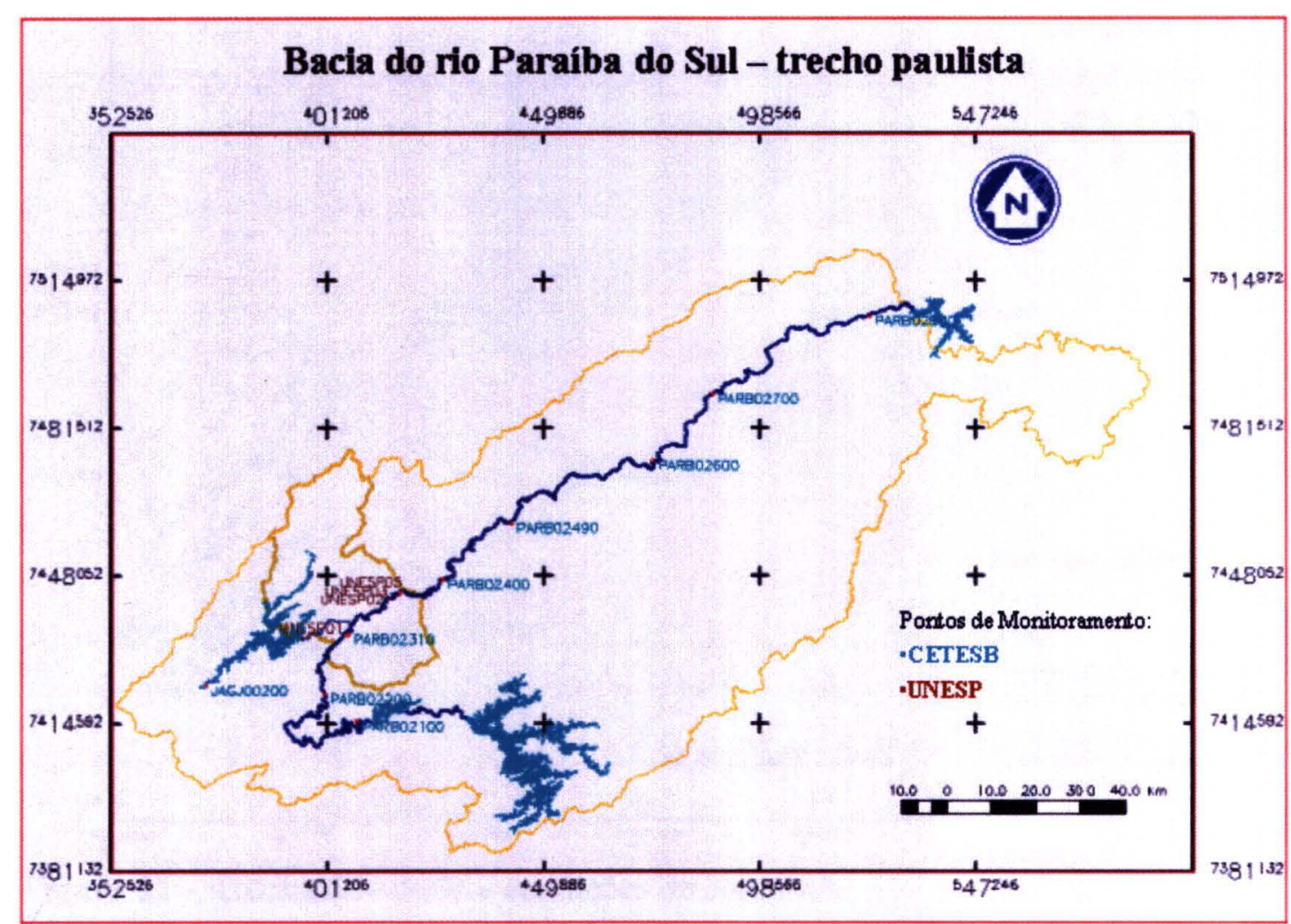

Figura 21- Bacia do Paraíba do Sul, com destaque para São José dos Campos.

Através da sobreposição destas informações, espacializadas no Sistema de Informação Geografia, no caso o SPRING, foi possível identificar o trecho de interesse no rio Paraíba do Sul, conforme apresentado na figura 22 a seguir, compreendido pelos postos de monitoramento de qualidade da água da CETESB PARB 02310 e PARB 02400, bem como os trechos associados às condições de contorno. 


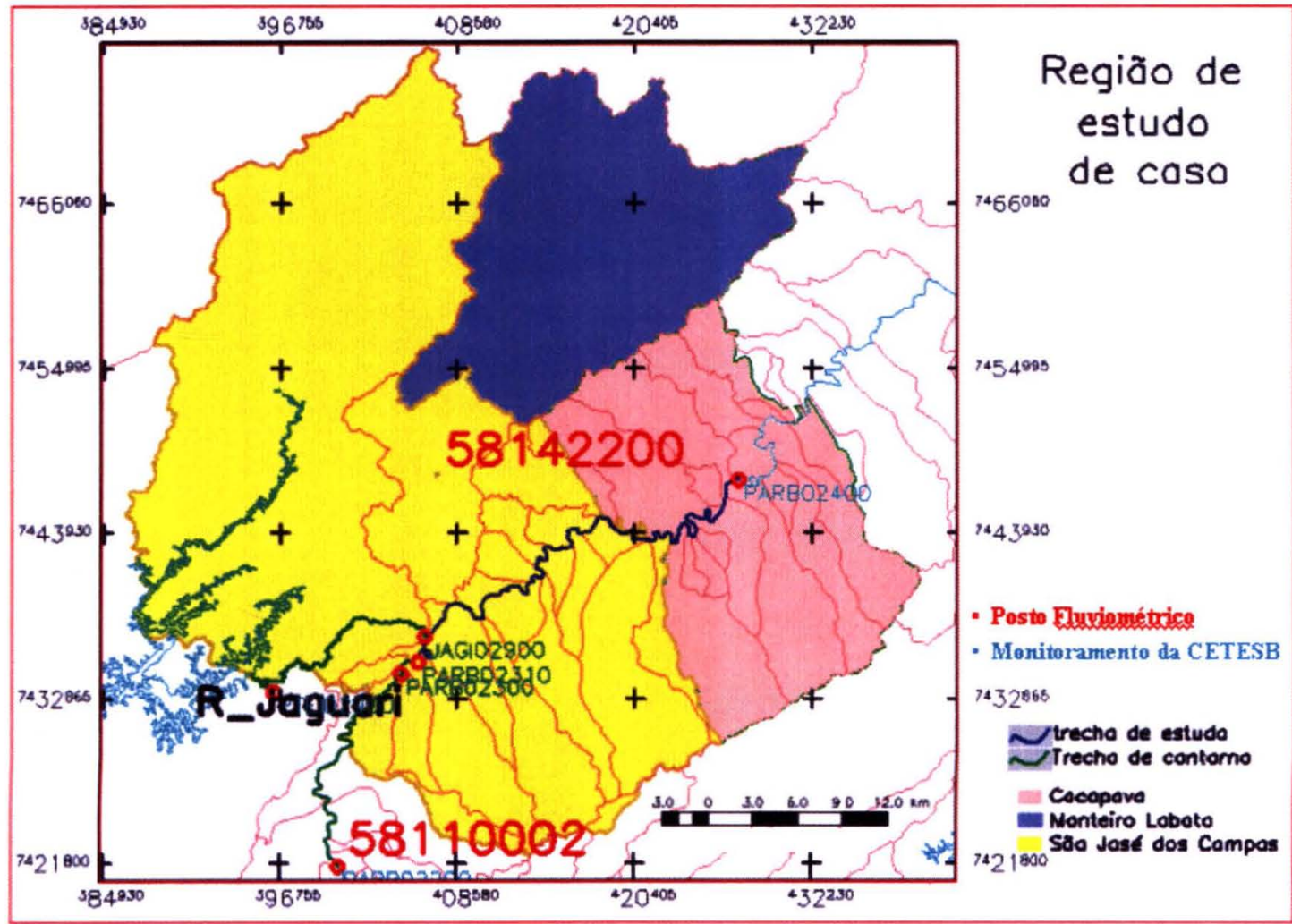

Figura 22 - Trecho de estudo e condições de contorno.

Uma vez definido o trecho de interesse, delimitou-se a área de abrangência do estudo, formada pelas sub-bacias dos afluentes diretos a este trecho (figura 22), resultando na área mostrada na figura 23.

A sub-bacia do Jaguari, situada no entorno do reservatório, à oeste da bacia do Paraíba (figura 23), foi considerada como condição de contorno ao trecho estudado, uma vez que se dispõe de dados de vazão no reservatório e de qualidade no ponto JAG 02900, no intuito de minimizar a abrangência das áreas de uso e ocupação/cobertura do solo a serem associadas aos incrementos de carga no trecho de estudo do rio.

Desta forma as condições de contorno para a referida área são obtidas de postos de monitoramento de qualidade, fluviométricos e de descarga do reservatório do Jaguari, situados nos rios Paraíba do Sul e em seu principal afluente, o rio Jaguari, logo à montante do trecho do estudo de caso. 


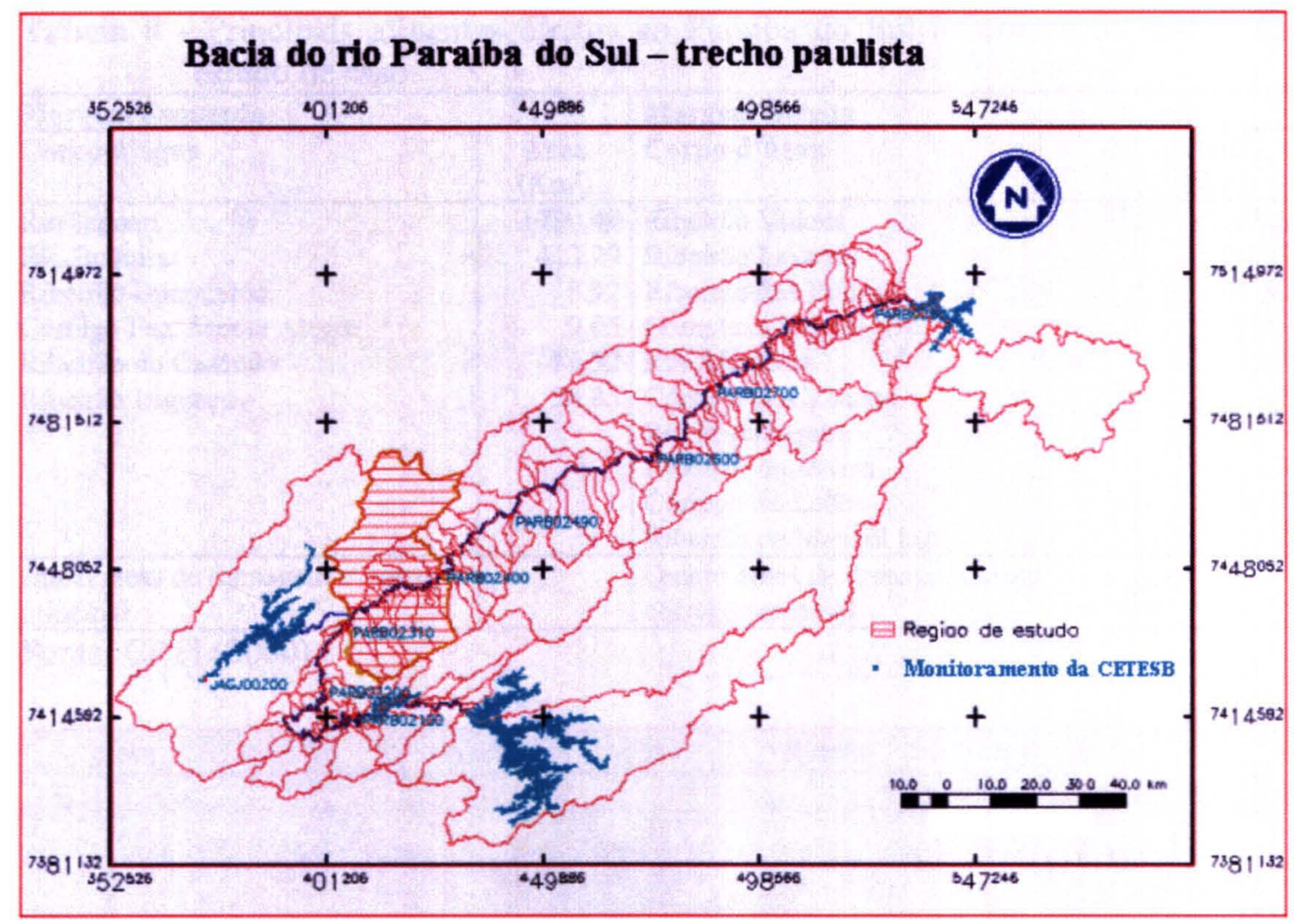

Figura 23. Região de estudo delimitada pelas sub-bacias.

Através da figura 22 pode-se observar que a abrangência da região ultrapassa os limites de São José dos Campos, envolvendo todo o município de Monteiro Lobato e parte de Caçapava e que ainda exclui as áreas das sub-bacias situadas região oeste e norte de São José dos Campos.

\section{Condição Hidrológica}

A região do estudo de caso apresenta 16 dos 139 afluentes diretos priorizados da bacia paulista no Relatório Zero da CPTI (2000), descritos na tabela 8 a seguir, sem computar 9 áreas de drenagem que não apresentam corpo de água principal.

As áreas de todos os afluentes prioritários são indicadas no Anexo $1 \mathrm{e}$ as da região de estudo na tabela 8 a seguir, cujas sub-bacias são mostradas na seqüência na figura 24, que apresenta uma divisão mais ampla realizada pela Prefeitura municipal de São José dos Campos, que resultou em mais três bacias de afluentes, referente às utilizadas para o estudo de macrodrenagem da área à margem direita do Paraíba do Sul. 
Tabela 8 - Principais afluentes diretos ao Paraíba do Sul no trecho da região do estudo de caso.

\begin{tabular}{|l|r|l|r|}
\hline Margem Esquerda & Margem Direita & \multicolumn{1}{c|}{$\begin{array}{c}\text { Área } \\
\left(\mathrm{Km}^{2}\right)\end{array}$} \\
\hline Corpo d'água & $\begin{array}{r}\text { Área } \\
\left(\mathrm{Km}^{2}\right)\end{array}$ & Corpo d'água & 43,6 \\
\hline Rio Jaguari & 1730,49 & Ribeirão Vidoca & 14,55 \\
Rio Buquira & 413,29 & Ribeirão Lavapés & 44,50 \\
Ribeirão Buerarema & 8,92 & Ribeirão dos Putins & 12,25 \\
Córrego Faz. Monte Alegre & 9,05 & Complexo hidrológico & 31,87 \\
Ribeirão do Cascudo & 31,32 & Rio Alambari & 10,17 \\
Ribeirão Iriguaçu & 38,85 & Córrego dos Veados & 71,57 \\
& & Rio Porarangaba & 61,57 \\
& & Ribeirão da Divisa & 5,27 \\
& & Córrego do Leões & 16,02 \\
\hline Cinco áreas de drenagem s/ córrego & & Ribeirão de Manoel Lírio & \\
principal & & Quatro áreas de drenagem s/ um & \\
\hline
\end{tabular}

Fonte: CPTI (2000).

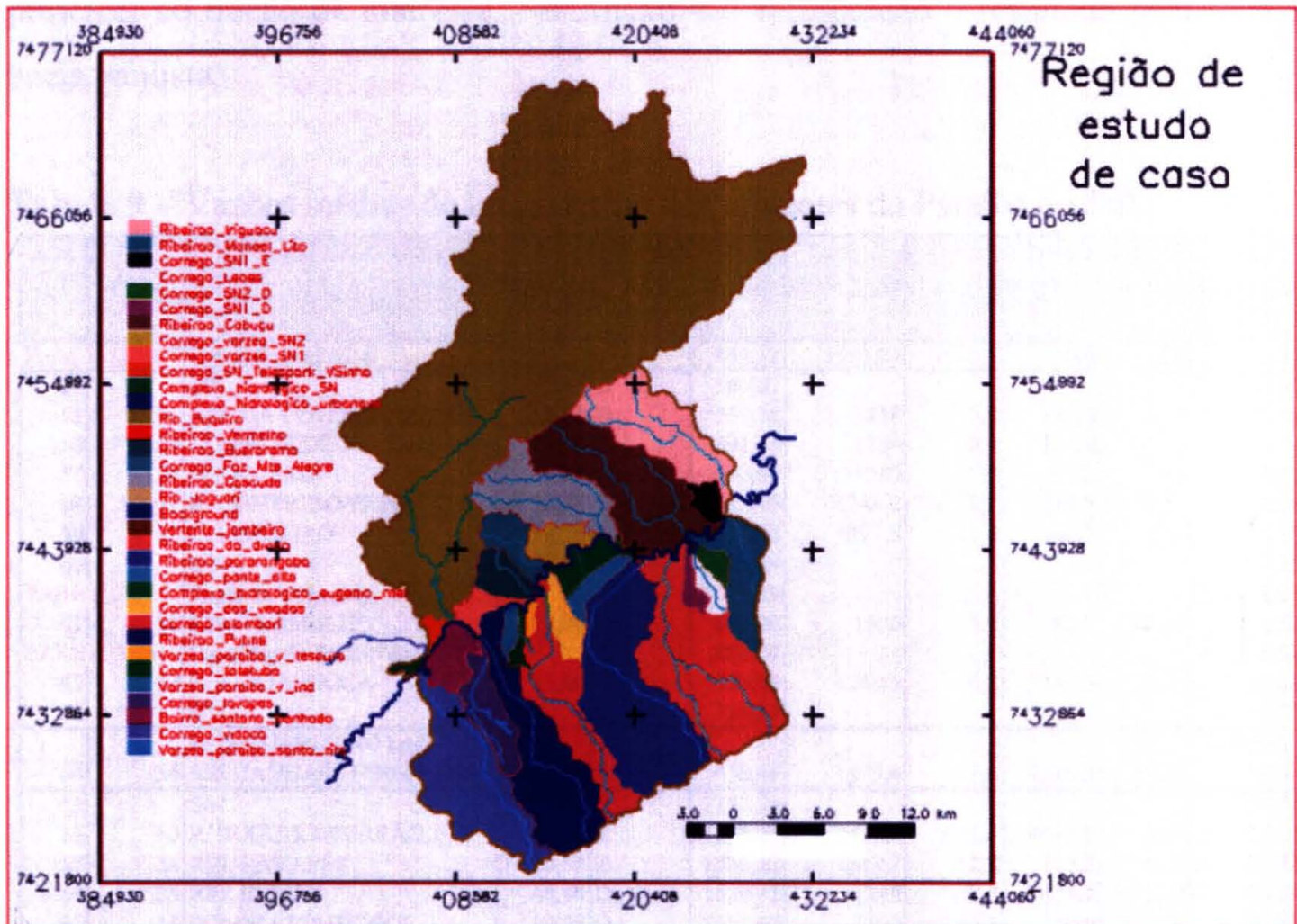

Figura 24 - Afluentes diretos do rio Paraíba do Sul na região de estudo e delimitação das sub-bacias.

A vazão de interesse é a média mensal, uma vez que é capaz de representar as variações sazonais, associadas às cargas de poluentes não pontuais. Seu calculo é feito a partir dos valores encontrados nos pontos de contorno. 
Para o rio Paraíba do Sul foram utilizados os dados do posto fluviométrico 58110002 da ANA, situado a montante do ponto de monitoramento de qualidade da água PARB 02400 (vide figura 22), sendo incrementado das vazões médias de longo termo referentes às sub-bacias afluentes e indicados na tabela 9, conforme a seqüência em que deságuam no Paraíba do Sul. A vazão referente à bacia do rio Jaguari, um dos principais formadores do Paraíba, é obtida através da descarga média mensal de seu reservatório complementada pelo incremento da vazão média de longo termo da bacia situada à jusante (tabela 8), até sua foz no Paraíba do Sul.

As vazões médias de longo termo, apresentadas na tabela 8 , foram calculadas a partir do modelo de regionalização hidrológica (DAEE 1988 e 1994) para a determinação dos incrementos de vazões oriundos das sub-bacias dos afluentes ao rio principal no trecho de interesse. No Anexo 4 é apresentado o resultado para toda a bacia paulista.

Tabela 9 - Vazões médias de longo termo dos afluentes do Paraíba do Sul.

\begin{tabular}{|c|c|c|c|c|c|c|c|c|c|c|}
\hline Un. & $\begin{array}{c}\mathrm{N}^{\circ} \\
\text { CPTI }\end{array}$ & NOME DA BACIA & $\begin{array}{l}\text { AREA } \\
\left(\mathrm{Km}^{2}\right)\end{array}$ & Margem & $\begin{array}{c}\text { Area } \\
\text { acumul. }\end{array}$ & $\begin{array}{c}\text { P média } \\
\text { plurianual } \\
(\mathrm{mm})\end{array}$ & $\begin{array}{c}\text { Qesp } \\
(\text { (1s.lkm2) }\end{array}$ & $\begin{array}{c}\text { Qmédia } \\
(\mathrm{l} / \mathrm{s})\end{array}$ & $\begin{array}{c}\text { Qmédia } \\
\left(\mathrm{m}^{3} / \mathrm{s}\right)\end{array}$ & $\begin{array}{c}\text { Qmédia } \\
\text { acumulada } \\
\left(\mathrm{m}^{3} / \mathrm{s}\right)\end{array}$ \\
\hline \multicolumn{2}{|c|}{ Posto 58110002} & Captaç̃o do SAAE & & & 543,52 & 5383,24 & 140,1 & 0,0 & 0,00 & 3,31 \\
\hline 54 & & $\mathrm{~S} / \mathrm{N}$ & 2,55 & D & 546,07 & & & & & 3,31 \\
\hline 55 & 30 & RIB. DA COLÔNIA (Rhodia) & 13,25 & D & 559,32 & 1218 & 8,9 & 117,9 & 0,12 & 3,42 \\
\hline 56 & 139 & COMPL HIDROL (Tanquinho) & 32,04 & E & 591,36 & 1250 & 9,9 & 317,4 & 0,32 & 3,74 \\
\hline 57 & 138 & S/N (C. Sêco) & 9,25 & D & 600,61 & 1250 & 9,9 & 91,6 & 0,09 & 3,83 \\
\hline 58 & 31 & R. COMPRIDO/Philips & 52,54 & D & 653,15 & 1244,2 & 9,7 & 510,8 & 0,51 & 4,34 \\
\hline 59 & 32 & C. LIMOEIRO & 14,75 & D & 667,90 & 1297,8 & 11,4 & 168,3 & 0,17 & 4,51 \\
\hline 60 & & $\mathrm{~S} / \mathrm{N}$ & 10,59 & E & 678,49 & & & & & 4,51 \\
\hline \multicolumn{2}{|c|}{ PARB 02300} & Ponte da Urbanova & & & 678,49 & & & & & 4,51 \\
\hline 61 & 50 & RIB. VERMELHO & 4,80 & E & 683,29 & 1350 & 13,1 & 62,7 & 0,06 & 4,57 \\
\hline \multicolumn{2}{|c|}{ PARB 02310} & Captação da Sabesp em SJC & & D & 683,29 & & & & & 4,57 \\
\hline 62 & 33 & RIB. DO VIDOCA & 43,60 & D & 726,89 & 1260,5 & 10,2 & 446,3 & 0,45 & 5,02 \\
\hline 63 & & $\mathrm{~S} / \mathrm{N}$ & & E & 726,89 & & & & & 5,02 \\
\hline 64 & 56 & \begin{tabular}{|l} 
R. JAGUARI $\left(1300 \mathrm{~km}^{2}\right)$ \\
RIB. JAGUARI $1730,49 \mathrm{Km}^{2}$
\end{tabular} & 430,49 & E & 430,49 & 1475,4 & 17,0 & 7320,5 & 7,32 & $\begin{array}{r}\text { QRJAG } \\
7,32 \\
\end{array}$ \\
\hline 65 & & $\mathrm{~S} / \mathrm{N}$ & & E & 1157,38 & & & & & 12,34 \\
\hline \multirow{2}{*}{$\begin{array}{l}66 \\
67\end{array}$} & 60 & R. BUQUIRA/FERRÃO & 413,29 & E & 1570,67 & 1679,4 & 23,4 & 9683,8 & 9,68 & 22,03 \\
\hline & 34 & RIB. LAVAPÉS & 14,55 & D & 1585,22 & 1323,3 & 12,2 & 177,7 & 0,18 & 22,20 \\
\hline \multirow{2}{*}{$\begin{array}{l}68 \\
69\end{array}$} & 35 & RIB. PUTINS & 44,50 & D & 529,72 & 1246 & 9,8 & 435,2 & 0,44 & 22,64 \\
\hline & 36 & COMPLEXO HIDROL. & 12,25 & D & 1641,97 & 1350 & 13,1 & 159,9 & 0,16 & 22,80 \\
\hline 70 & & $\mathrm{~S} / \mathrm{N}$ & & E & 1641,97 & & & & & 22,80 \\
\hline \multirow{2}{*}{$\begin{array}{l}71 \\
72\end{array}$} & 64 & RIB. BUERAREMA & 8,92 & E & 1650,89 & 1399,1 & 14,6 & 130,2 & 0,13 & 22,93 \\
\hline & 37 & R. ALAMBARI & 31,87 & D & 1682,76 & 1287,8 & 11,1 & 353,6 & 0,35 & 23,28 \\
\hline \multirow{2}{*}{$\begin{array}{l}73 \\
74\end{array}$} & 66 & C. FAZ. MONTE ALEGRE & 9,05 & E & 1691,81 & 1430,1 & 15,6 & 141,0 & 0,14 & 23,42 \\
\hline & & $\mathrm{S} / \mathrm{N}$ & & D & 1691,81 & & & & & 23,42 \\
\hline 75 & 38 & C. DOS VEADOS & 10,17 & D & 1701,98 & 1350 & 13,1 & 132,8 & 0,13 & 23,56 \\
\hline \multirow{2}{*}{$\begin{array}{l}76 \\
77\end{array}$} & & $\mathrm{~S} / \mathrm{N}$ & & E & 1701,98 & & & & & 23,56 \\
\hline & 68 & RIB. CASCUDO/BUTA & 31,32 & E & 1733,30 & 1469,7 & 16,8 & 527,0 & 0,53 & 24,08 \\
\hline \multirow{2}{*}{$\begin{array}{l}78 \\
79\end{array}$} & & $\mathrm{~S} / \mathrm{N}$ & & D & 1733,30 & & & & & 24,08 \\
\hline & 39 & R. PARARANGABA & 71,57 & D & 1804,87 & 1283,4 & 11,0 & 784,2 & 0,78 & 24,87 \\
\hline 80 & 40 & RIB. DA DIVISA & 61,57 & D & 1866,44 & 1272 & 10,6 & 652,5 & 0,65 & 25,52 \\
\hline \multirow{2}{*}{$\begin{array}{l}81 \\
82\end{array}$} & & $\mathrm{~S} / \mathrm{N}$ & & D & 1866,44 & & & & & 25,52 \\
\hline & 41 & C. DOS LEÕES & 5,37 & D & 1871,81 & 1338,4 & 12,7 & 68,1 & 0,07 & 25,59 \\
\hline \multirow{2}{*}{$\begin{array}{l}83 \\
84\end{array}$} & & $\mathrm{~S} / \mathrm{N}$ & & D & 1871,81 & & & & & 25,59 \\
\hline & 70 & RIB. CABUÇU & 46,19 & E & 1918,00 & 1425,1 & 15,4 & 712,3 & 0,71 & 26,30 \\
\hline 85 & & $\mathrm{~S} / \mathrm{N}$ & & E & 18,00 & & & & & 26,30 \\
\hline \multirow{2}{*}{$\begin{array}{l}86 \\
87\end{array}$} & 42 & RIB. MANOEL LITO & 16,02 & D & 1934,02 & 1312,1 & 11,9 & 190,0 & 0,19 & 26,49 \\
\hline & 73 & RIB. IRIGUAÇU & 38,85 & E & 1972,87 & 1469,3 & 16,8 & 653,2 & 0,65 & 27,14 \\
\hline \multicolumn{2}{|c|}{ PARB 02400} & & 859,09 & & & & & & & 27,14 \\
\hline
\end{tabular}


$\mathrm{Na}$ tabela 10 a seguir são apresentadas as vazões nos pontos de monitoramento, ao longo do trecho estudado, bem como a variação sazonal ao longo deste trecho, sendo representado na figura 25 , os dados para todo o trecho paulista do rio Paraíba do Sul, na forma de gráfico.

Tabela 10 - Vazões ao longo do trecho de estudo do rio Paraíba do Sul.

\begin{tabular}{|c|c|c|c|c|c|c|c|c|c|}
\hline UGRHI: & \multicolumn{3}{|c|}{ PARAIBA DO SUL } & \multicolumn{6}{|c|}{ Ano : 2003} \\
\hline Corpo d'água & Pto de Medi & & fev-03 & abr-03 & jun-03 & ago-03 & out -03 & dez-03 & $\mathbf{Q}_{\mathrm{MLT}}$ \\
\hline rio Jaguari & $\begin{array}{l}\text { ONS } \\
\text { JAGI }\end{array}$ & $\begin{array}{c}\text { Q. deflu do } \\
\text { reservat. } \\
02900\end{array}$ & $\begin{array}{l}10,00 \\
17,32\end{array}$ & $\begin{array}{l}10,00 \\
17,32\end{array}$ & $\begin{array}{l}10,00 \\
17,32\end{array}$ & $\begin{array}{l}20,00 \\
27,32\end{array}$ & $\begin{array}{l}12,00 \\
19,32\end{array}$ & $\begin{array}{l}10,00 \\
17,32\end{array}$ & $\begin{array}{c}0 \\
7,32\end{array}$ \\
\hline $\begin{array}{c}\text { rio Paraíba do } \\
\text { Sul }\end{array}$ & $\begin{array}{c}\text { Posto ANA } \\
\text { PARB } \\
\text { PARB } \\
\text { foz }\end{array}$ & $\begin{array}{c}58110002 \\
02300 \\
02310 \\
\text { Jaguari }\end{array}$ & $\begin{array}{l}47,12 \\
48,32 \\
48,38 \\
66,15\end{array}$ & $\begin{array}{l}40,57 \\
41,77 \\
41,83 \\
59,60\end{array}$ & $\begin{array}{l}117,46 \\
118,66 \\
118,72 \\
136,49\end{array}$ & $\begin{array}{r}76,66 \\
77,86 \\
77,92 \\
105,69\end{array}$ & $\begin{array}{l}43,79 \\
44,99 \\
45,05 \\
64,82\end{array}$ & $\begin{array}{l}40,57 \\
41,77 \\
41,83 \\
59,60\end{array}$ & $\begin{array}{c}3,31 \\
4,51 \\
4,57 \\
12,34\end{array}$ \\
\hline & PARB & 02400 & 80,95 & 74,40 & 151,29 & 120,49 & 79,62 & 74,40 & 27,14 \\
\hline
\end{tabular}

Observações: Em azul: dados oriundos de medições

Em preto: dados obtidos de cálculo, ou seja, dados de medições de posto à montante, incrementado de QMLT até o pto de interesse

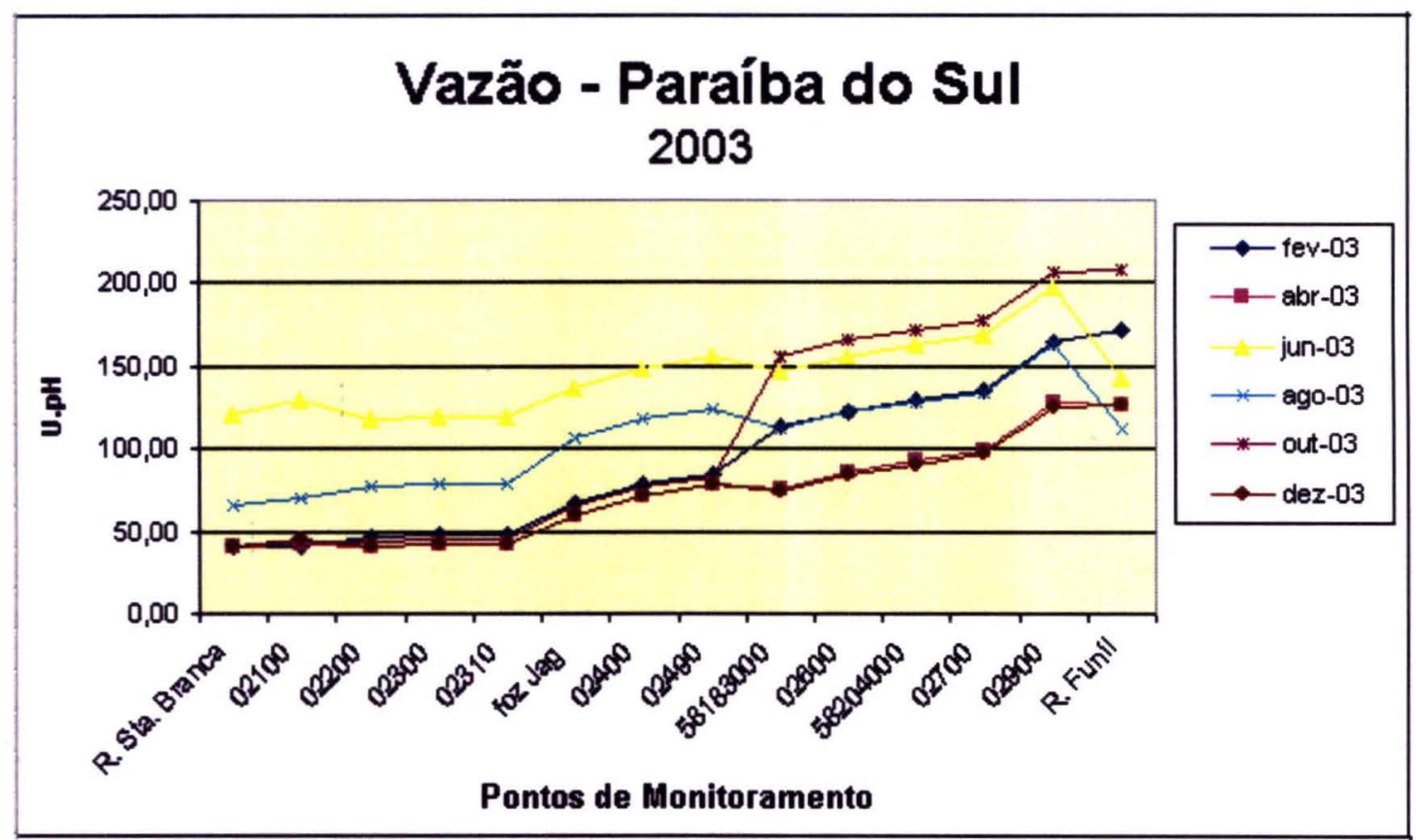

Figura 25 - Vazão ao longo do trecho paulista do rio Paraíba do Sul.

A partir da vazão e dos parâmetros de qualidade que apresentam evolução, encontrando-se acima dos padrões legais, e que podem estar associados à carga poluidora de origem difusa, determinou-se as cargas presentes no Paraíba do Sul. 
Para os pontos de amostragem de qualidade da água da CETESB foram calculadas as cargas poluidoras referentes aos parâmetros Alumínio, DQO, Fósforo total, NKT, Resíduo Filtrável e Coliforme Fecal. Para estes foi verificado que houve incremento de carga introduzida no trecho de estudo deste trabalho, ou seja, entre os pontos PARB 02310 e PARB 02400, conforme listadas no Anexo 5, a menos do parâmetro Coliforme Fecal. As figuras 26 a 30 mostram o gráfico de evolução das cargas ao longo do rio Paraíba dos Sul no estado de São Paulo.

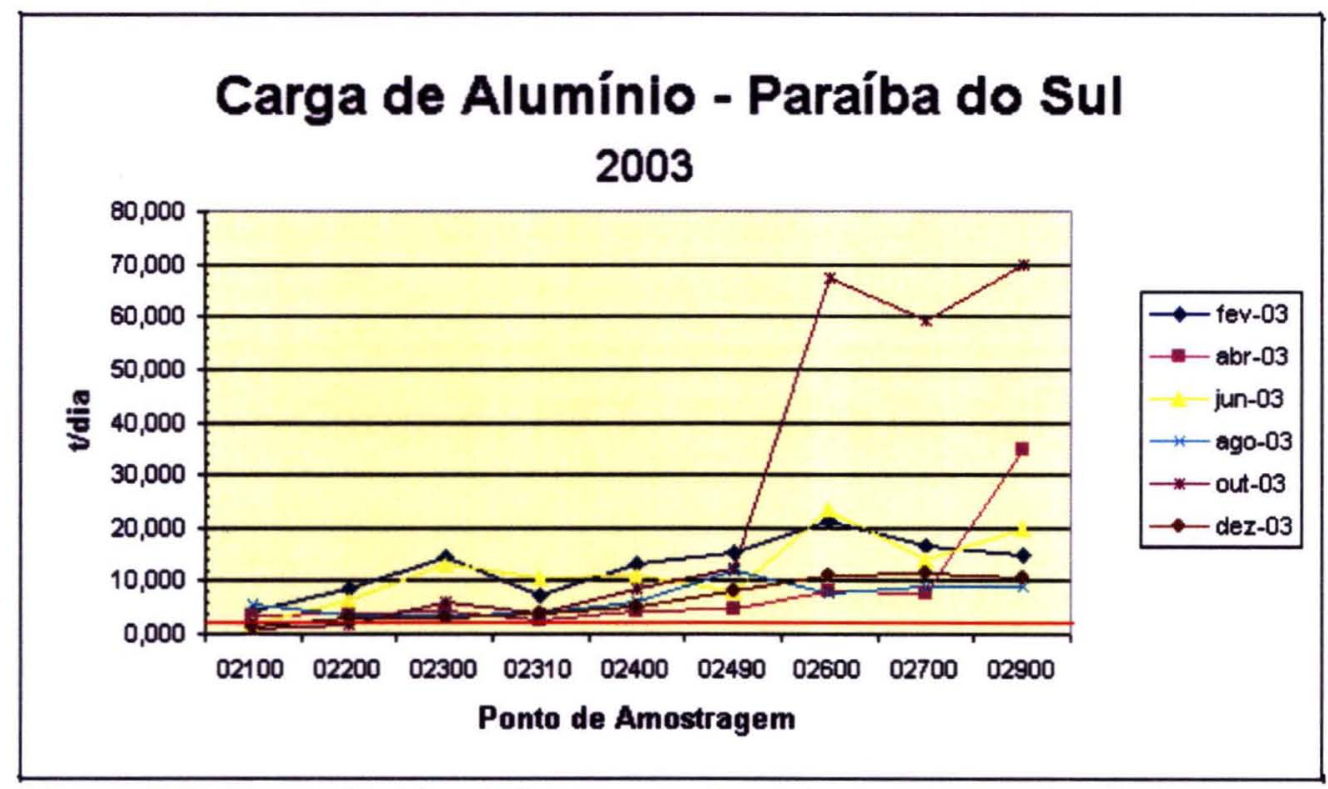

Figura 26 - Carga de Alumínio encontrada ao longo do Paraíba do Sul.

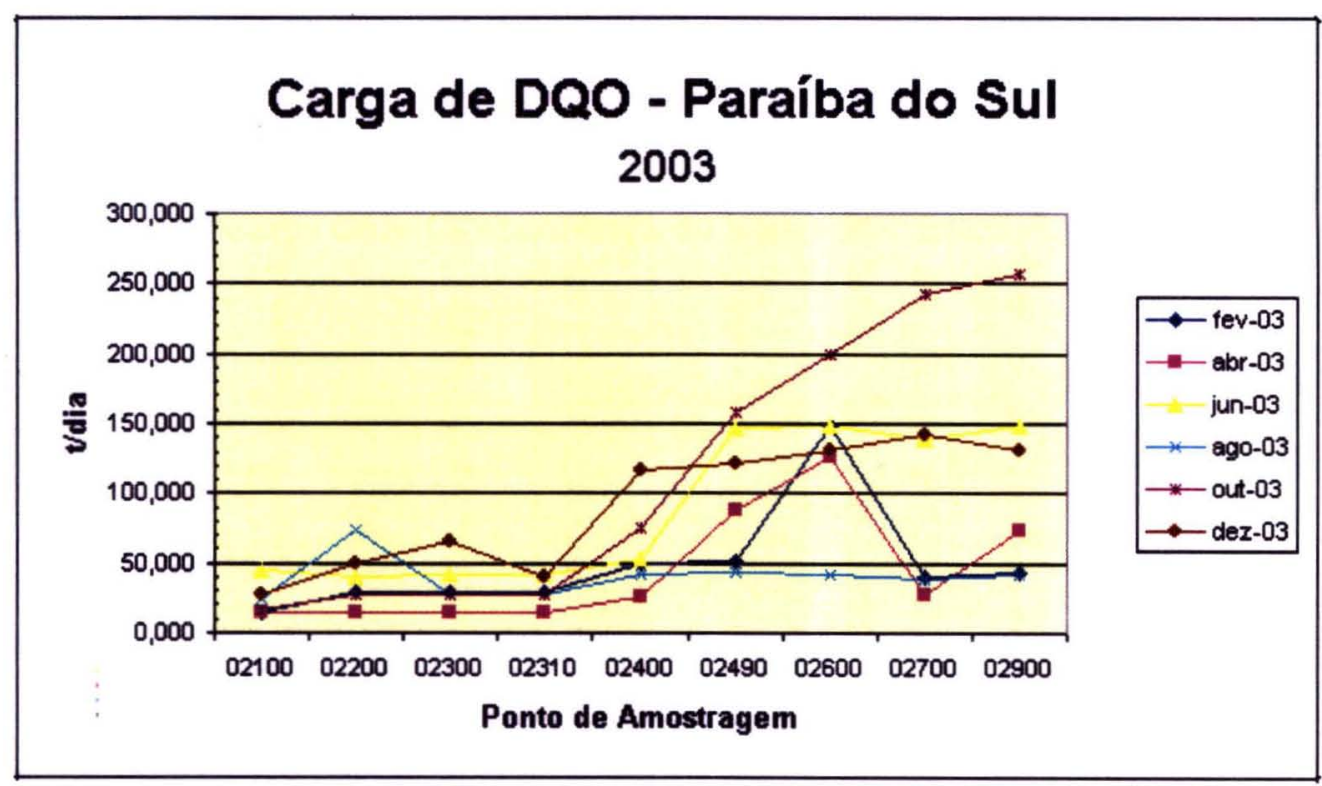

Figura 27 - Carga de DQO encontrada ao longo do Paraíba do Sul. 


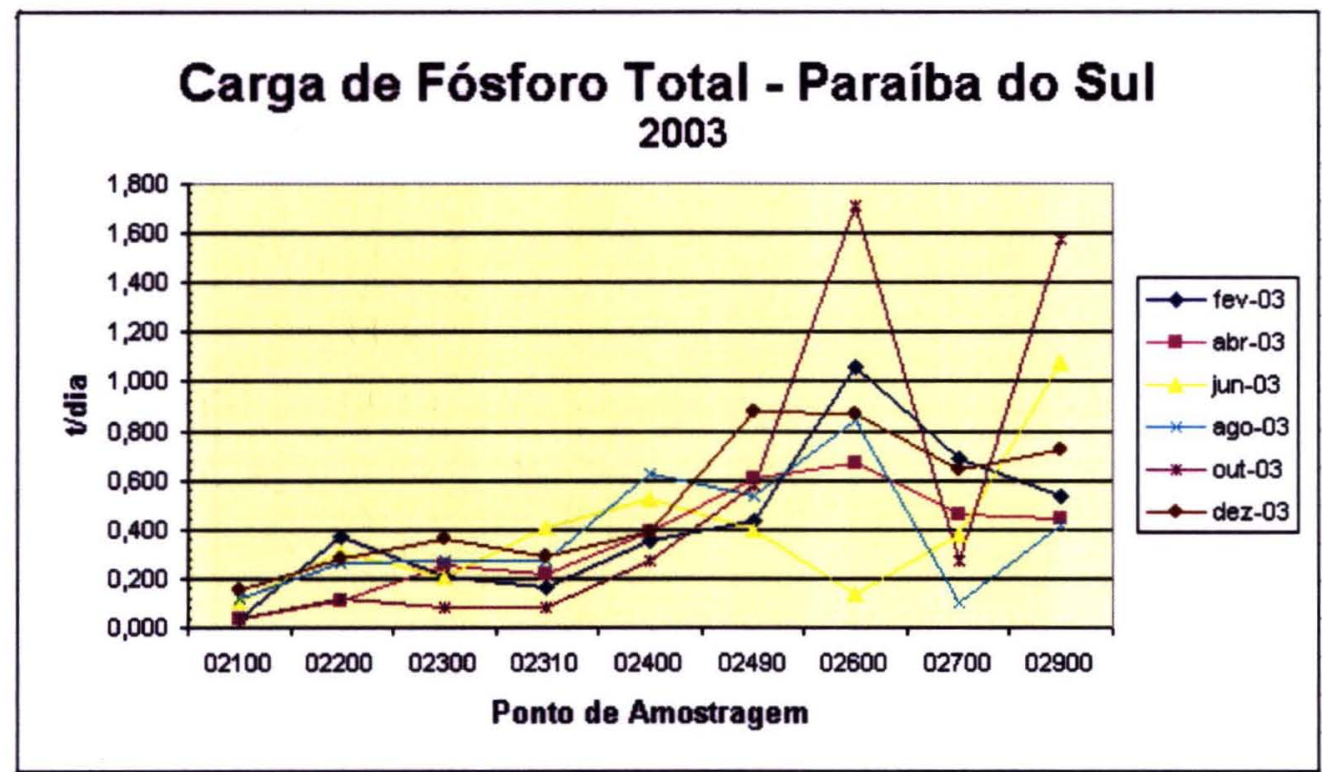

Figura 28 - Carga de Fósforo total encontrada ao longo do Paraíba do Sul.

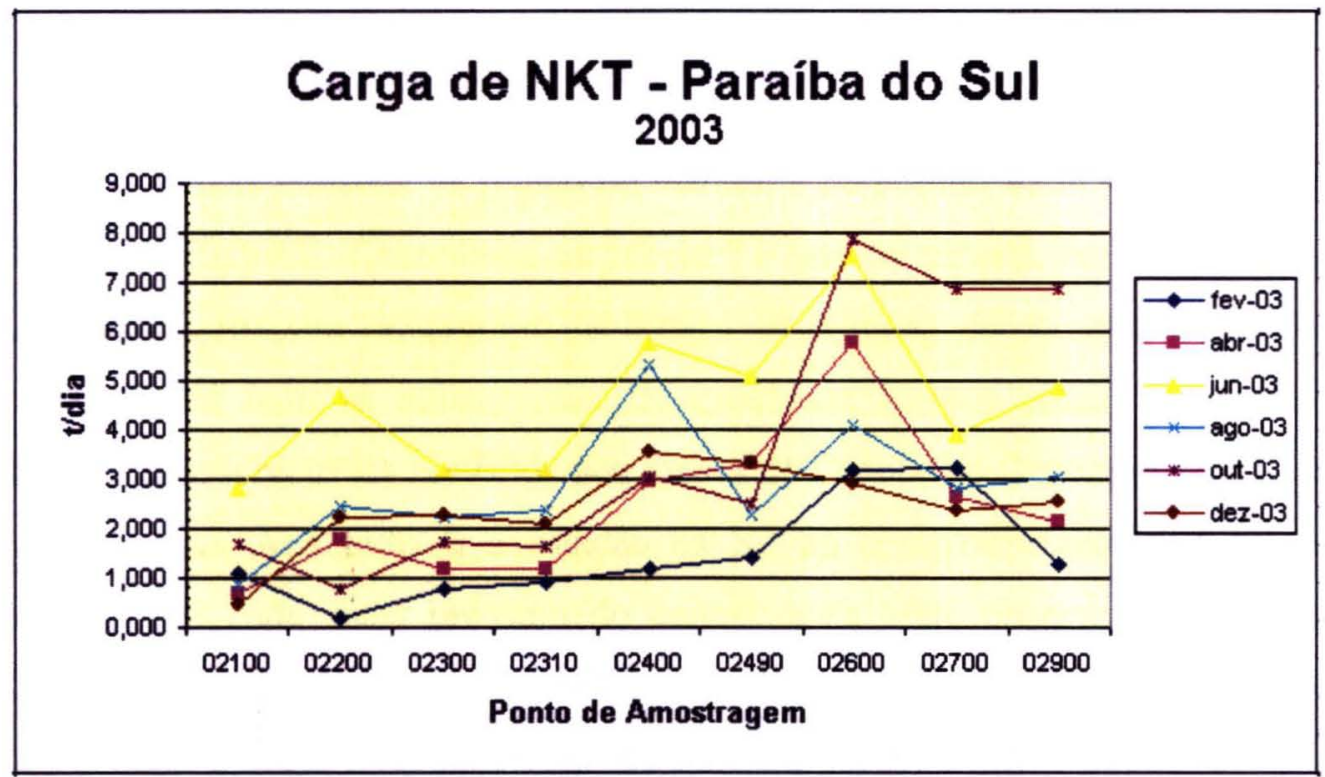

Figura 29 - Carga de NKT encontrada ao longo do Paraíba do Sul. 


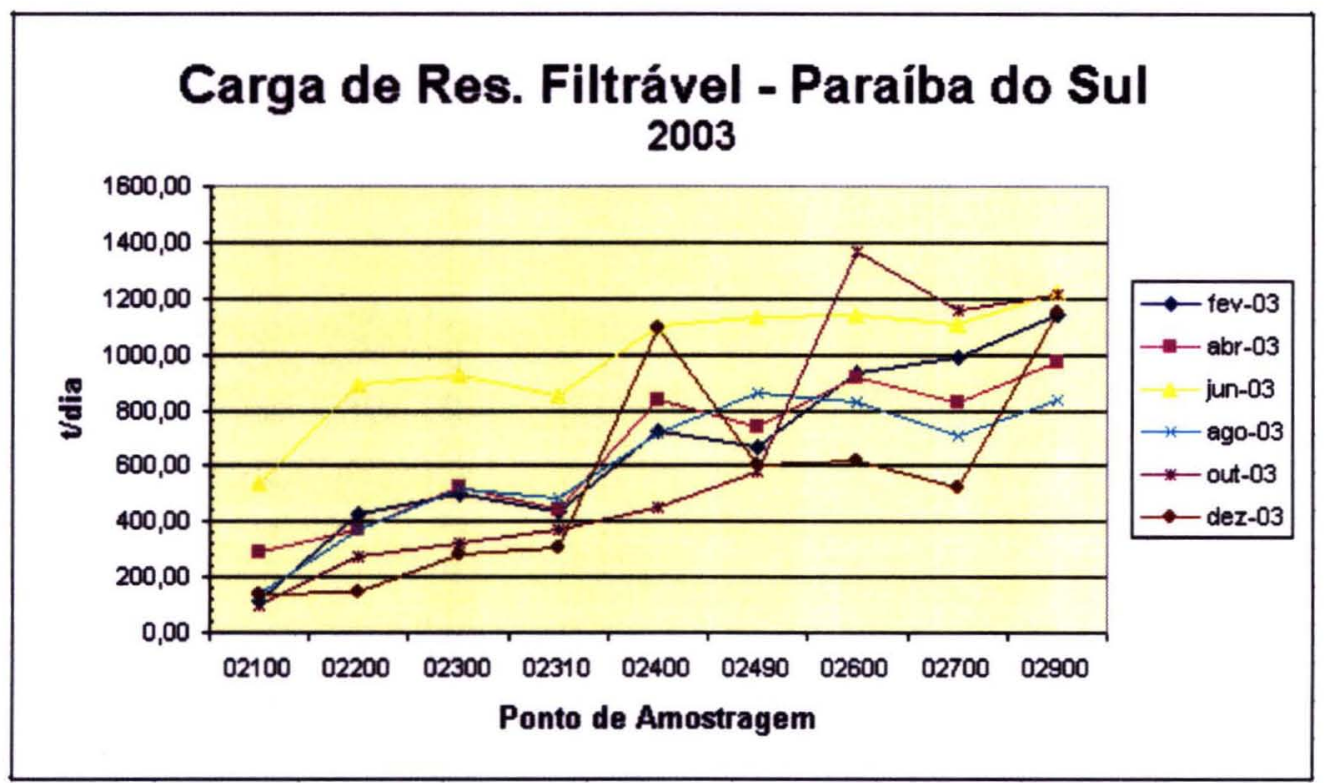

Figura 30 - Carga de Resíduo Filtrável encontrada ao longo do Paraíba do Sul.

Com o intuito de avaliar a associação das cargas adicionadas no trecho em estudo com eventos pluviométricos foram levantados os dados de duas estações pluviométricas situadas na região de estudo, a de código 02345064 da ANA e a da Petrobras/REVAP. Observa-se na tabela 11 que os valores encontrados para 2003 nas duas estações encontram-se muito próximos, sendo que para os meses coincidentes com as amostragens de qualidade (meses pares) foram registrados índices pluviométricos elevados nos meses de Outubro e Dezembro/2003, da ordem de $160 \mathrm{~mm}$. Adotando-se a estação da Revap como representativa da região de estudo, por estar mais próxima do centro desta área, observa-se que no mês de Fevereiro/2003 o índice pluviométrico situa-se num patamar um pouco inferior aos de outubro e dezembro, com valor de $56 \mathrm{~mm}$, porém ainda diferenciado em relação ao restante dos meses de coleta onde não há a ultrapassagem da casa de $15 \mathrm{~mm}$ mensais. 
Tabela 11 - Precipitação mensal acumulada na área de estudo.

\begin{tabular}{|c|c|c|}
\hline 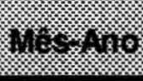 & Din & 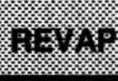 \\
\hline jan-03 & 310 & 307 \\
\hline (1) & 606 & 36. \\
\hline mar-03 & 97 & 126 \\
\hline 2010.03 & 25 & 13 \\
\hline mai-03 & 25 & 24 \\
\hline 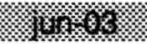 & 8 & 2 \\
\hline jul-03 & 27 & 26 \\
\hline 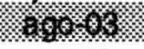 & 16 & (1) \\
\hline set-03 & 14 & 13 \\
\hline 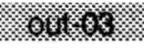 & 168 & $18 \%$ \\
\hline nov-03 & 104 & 112 \\
\hline$(60,083)$ & 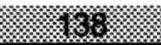 & 166. \\
\hline
\end{tabular}

Observando-se a evolução das cargas adicionadas no trecho entre os pontos de monitoramento de qualidade PARB 02310 e 02400, mês a mês, excluindo-se a carga introduzida através do rio Jaguari, conforme a tabela 11, avaliou-se a sua correlação com a evolução do índice pluviométrico.

A ferramenta de correlação é usada para determinar se dois conjuntos de dados se movem juntos, isto é, se os maiores valores de um conjunto estão associados com os maiores valores do outro (correlação positiva), se os menores valores de um conjunto estão associados com os maiores valores do outro (correlação negativa), ou se os valores dos dois conjuntos não se relacionam (correlação próxima a zero).

O cálculo da correlação da população retorna a covariância de dois conjuntos de dados dividida pelo produto de seus desvios padrão.

$$
\begin{aligned}
& \rho_{X, Y}=\frac{\operatorname{cov}(X, Y)}{\sigma_{X} \cdot \sigma_{Y}} \\
& \text { onde } \\
& \sigma_{X}^{2}=\frac{1}{n} \sum\left(X_{;}-\mu_{X}\right)^{2} \\
& \text { e } \\
& \sigma_{Y}^{2}=\frac{1}{n} \sum\left(Y_{j}-\mu_{H}\right)^{2}
\end{aligned}
$$

onde,

$\mathbf{X}_{1}, \mathbf{X}_{2}, \ldots, \mathbf{X}_{\mathbf{n}}$ e $\mathbf{Y}_{1}, \mathbf{Y}_{2}, \ldots, \mathbf{Y}_{\mathbf{n}}$ são os valores medidos de ambas as variáveis;

$\mu_{\mathrm{x}}$ e $\mu_{\mathrm{y}}$ são as médias aritméticas de ambas as variáveis. 
Aplicando-se o cálculo de correlação entre o aporte de carga poluidora referente aos parâmetros de qualidade no trecho em estudo e a pluviosidade, obtevese forte correlação entre esta e a carga de DQO, que apresentou um coeficiente de correlação igual a 0,9488 , conforme pode-se observar na tabela 11. Já para a carga de Alumínio o coeficiente de correlação apresentou resultado de 0,0648 o que indica a pouca correlação entre os parâmetros.

Tabela 12 - Carga adicionada no trecho do estudo de caso e correlação com a pluviosidade.

\begin{tabular}{|c|c|c|c|c|c|c|c|c|}
\hline${ }_{1} \ldots x$ & 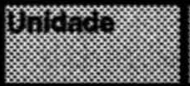 & 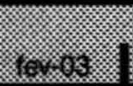 & mys & 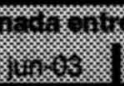 & H. & 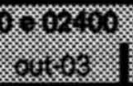 & s; & 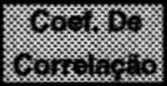 \\
\hline W & 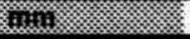 & 56 & 15 & 5 & 11 & 159 & 166 & \\
\hline Hixing & 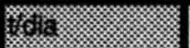 & 0,496 & 1,174 & 0,383 & 1,402 & 1,525 & 0,505 & 0,0648 \\
\hline 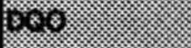 & 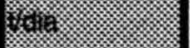 & 9,223 & 5,270 & 5,270 & 5,270 & 41,749 & 65,478 & 0,9488 \\
\hline s\% & 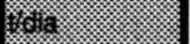 & 0,153 & 0,139 & 0,038 & 0,214 & 0,097 & $-0,068$ & $-0,5911$ \\
\hline$H_{x} x_{x}$ x & 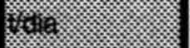 & $-0,04$ & 1,39 & 2,00 & 2,50 & $-1,95$ & 0,92 & $-0,7173$ \\
\hline 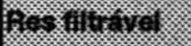 & 聯縈暃 & 222,33 & 242,98 & 125,42 & 172,22 & 18,03 & 740,71 & 0,4237 \\
\hline 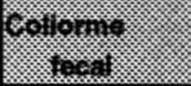 & 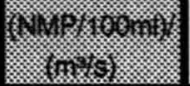 & $-1,0 E+06$ & $5,1 E+04$ & $2,6 E+05$ & $-8,1 E+05$ & $-5,9 E+05$ & $-1,5 E+05$ & $-0,1429$ \\
\hline
\end{tabular}

A carga presente durante o período de seca, representada pelos meses de Abril, Junho e Agosto de 2003, conforme observa-se pelo índice pluviométrico apresentado nas tabelas 10 e 11, equivale a carga permanente, ou seja, representa a carga lançada do rio Paraíba continuamente, portanto de origem pontual, doméstica ou industrial, mediante tratamento prévio ou não.

Para o parâmetro DQO a carga permanente é de 5,27 t/dia e para Resíduo filtrável é de 180,21 t/dia, calculados através da média dos resultados referentes a este período.

A diferença entre a carga permanente e a carga total lançada nos meses de maior intensidade pluviométrica refere-se a parcela lançada através do carreamento provocado pelo deflúvio superficial. Identificou-se os meses de Outubro e Dezembro com os maiores índices pluviométricos e o mês de Fevereiro apresentando pluviosidade significativa, porém com intensidade $1 / 3$ inferior ao período de maior pluviosidade. 
Portanto a carga adicional lançada no período de maior pluviosidade é de 48,34 t/dia e de 560,5 t/dia para os parâmetros DQO e Resíduo filtrável, respectivamente e para o mês de fevereiro é de 3,95 t/dia e 42,12 t/dia, também para os referidos parâmetros.

\section{Imagem}

A figura 31 mostra mosaico realizado de imagens de satélite, que caracteriza muito bem a bacia paulista do Paraíba do Sul, destacando a região de estudo, e que pode ser utilizada para classificação de uso e ocupação/cobertura do solo, ou mesmo para auxílio na delimitação das sub-bacias, não sendo utilizado no estudo de caso deste trabalho que já dispunha de dados elaborados, servindo apenas para efeito ilustrativo.

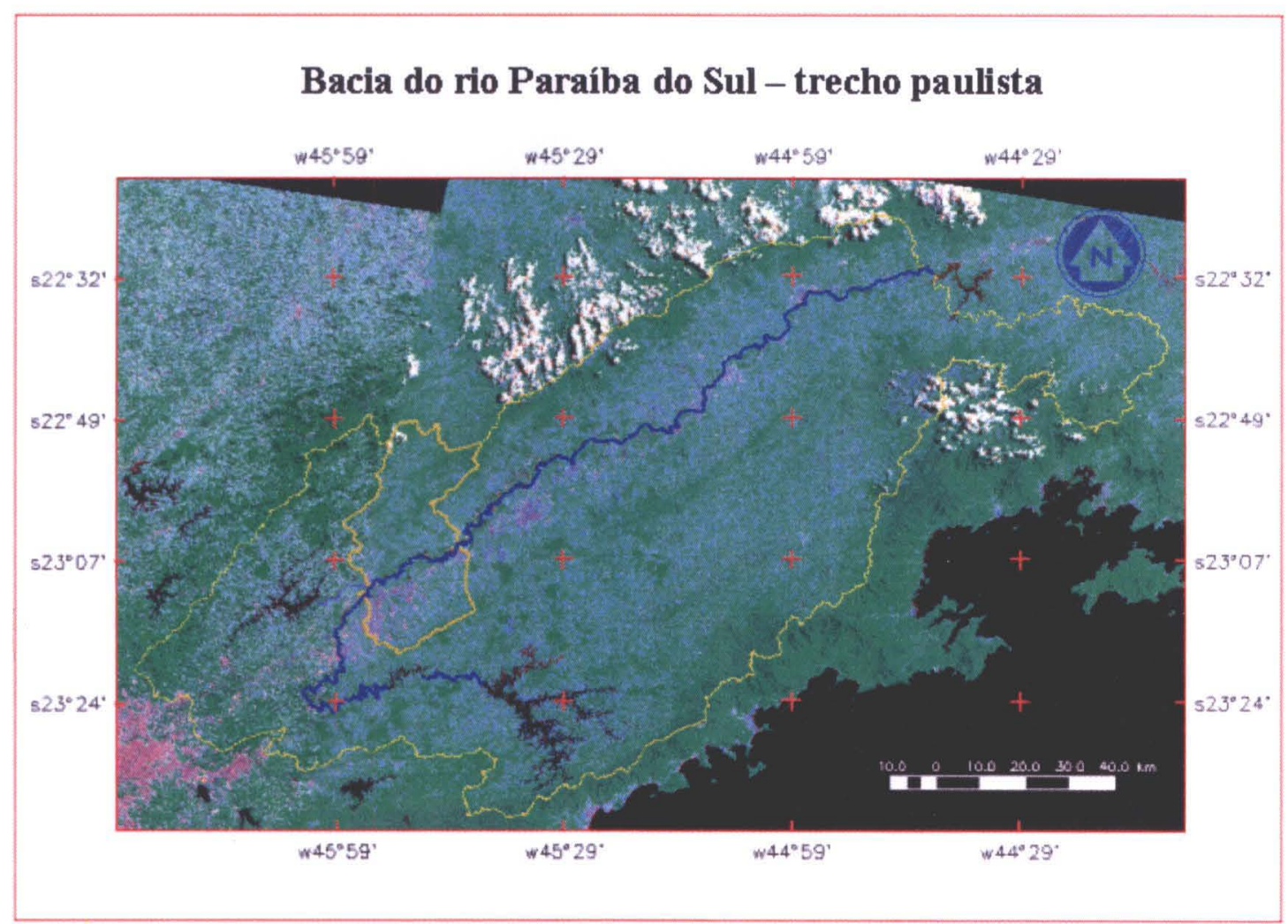

Figura 31 - Mosaico de imagens da bacia paulista do Paraíba do Sul. Composição das bandas 3, 4 e 5 do satélite Landsat, de junho/2002, com destaque para a região de estudo. 
A figura 32 apresentada na seqüência refere-se a Plano de Informação do SPRING com a classificação de uso e ocupação/cobertura do solo para as sub bacias dos afluentes diretos ao Paraíba do Sul da região de estudo, gerado e utilizado como base para a avaliação das cargas difusas, uma vez que a bacia hidrográfica é o território mais adequado para este propósito, por estar diretamente associado ao escoamento superficial.

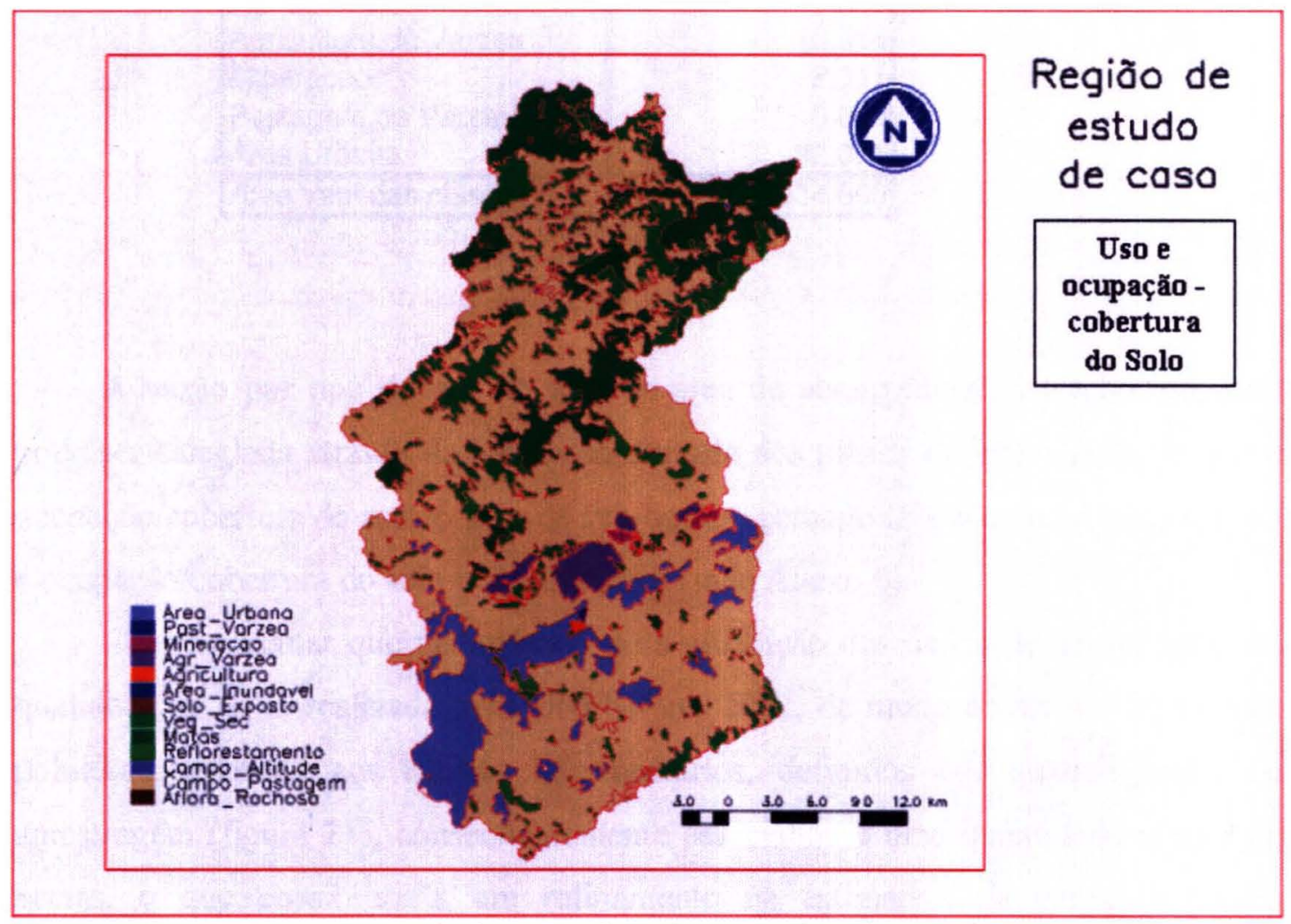

Figura 32 - Uso e ocupação/cobertura do solo na região de estudo.

Quantificou-se as áreas de uso e ocupação/cobertura do solo da região estudada através da ferramenta de medida de classes do SPRING, sendo apresentada o resultado na tabela 13 a seguir. 
Tabela 13 - Resumo das vazões associadas ao uso e ocupação/cobertura do solo da região estudada.

\begin{tabular}{|l|r|}
\hline \multicolumn{1}{|c|}{. } \\
\hline Afloramento Rochoso & 0,133 \\
Campos e Pastagem & 668,001 \\
Campos de Altitude & 0,418 \\
Reflorestamento & 15,846 \\
Matas & 125,955 \\
Vegetação Secundária & 111,164 \\
Solo Exposto & 0,122 \\
Área Inundavel : & 0,592 \\
Agricultura & 1,301 \\
Agricultura de Varzea & 16,954 \\
Mineracao & 2,311 \\
Pastagem de Varzea & 0,000 \\
Área Urbana & 92,071 \\
\hline Area total das classes: & 1034,869 \\
\hline
\end{tabular}

A vazão por tipo de uso do solo da área de abrangência do trecho estudado pode ser calculada através da tabulação cruzada dos planos de informação de uso e ocupação/cobertura do solo com o de sub-bacias, gerando tabela com as áreas de uso e ocupação/cobertura do solo por sub-bacias (vide Anexo 6).

Cabe ressaltar que vislumbrava-se a utilização dos dados de amostragem de qualidade da água realizada pela UNESP em 2002, de modo a calcular-se a carga poluidora referente aos trechos intermediários, definidos por quatro pontos de amostragem (figura 21), conseqüentemente associados a uma quantidade menor de bacias, o que possibilitaria um refinamento na estimativa da carga poluidora relacionadas a uma variedade menor de uso e ocupação/cobertura do solo. Porém a ausência de dados de vazão de descarga na represa do Jaguari (condição de contorno significativa, como pode-se observar nas vazões dos períodos disponíveis) no período de estudo da UNESP frustrou esta possibilidade. 


\section{CONCLUSÕES}

Através da aplicação da metodologia foi possível identificar a correlação entre o índice pluviométrico e o aporte de carga poluidora referente aos parâmetros DQO e Resíduo filtrável (para este, excetuando-se o resultado de Outubro/2003, que apresenta-se bem distinto dos demais) representantes da qualidade da água no trecho em estudo. Para o aporte de carga referente ao parâmetro DQO e Resíduo não filtrável os coeficientes de correlação encontrados foram de 0,9488 e 0,9686, respectivamente. Já para a carga de Alumínio o coeficiente de correlação apresentou resultado de 0,0648 , indicando pouca correlação entre os parâmetros.

Para as cargas referentes aos demais parâmetros não foi possível identificar nenhuma correlação ou tendência.

A partir da carga calculada para os poluentes associados a fontes difusas e dispondo-se das vazões médias associadas ao uso e ocupação/cobertura do solo (passível de ser calculada com as áreas referentes ao uso e ocupação do solo por subbacia constantes no Anexo 6, obtidas através de ferramentas do SPRING) pode-se calcular as concentrações esperadas médias dos poluentes de origem difusa (do inglês: Expected Mean Concentration - EMC).

Para a região de estudo observou-se a predominância de uso e ocupação/cobertura do solo referente a campos e pastagens, bem como de intensa atividade urbana, além de matas e vegetação secundária, que a princípio não apresentam contribuição significativa de poluição de origem difusa.

Para o estudo de caso não foi possível determinar as concentrações esperadas médias dos poluentes em virtude do espaçamento excessivo entre os pontos de monitoramento de qualidade da água, que representa o trecho em estudo, sendo receptor da contribuição de várias sub-bacias.

Cabe lembrar que a unidade responsável pelo planejamento, fiscalização e controle do uso e ocupação do solo (verificar a constituição) é o município, portanto para viabilizar a associação de uso do solo urbano com qualidade da água é necessário que haja uma rede adequada de monitoramento que represente as subbacias situadas na área urbana. 
Ainda sim é possível concluir que a metodologia utilizada permite uma melhor compreensão dos processos de alteração da qualidade das águas superficiais em bacias hidrográficas relacionadas ao espaço geográfico, ou seja, decorrentes de alterações proporcionadas por cargas difusas oriundas do uso e ocupação/cobertura do solo e por cargas pontuais introduzidas ao longo dos cursos d'água. Esta conclusão é reforçada pela forte associação dos parâmetros DQO e Resíduo não filtrável com a intensidade pluviométrica, que representam bem os usos preponderantes na área de estudo, ou seja, urbano e campos e pastagens, respectivamente.

A eficiência das medidas de controle de poluentes também poderá ser avaliada, como por exemplo, as faixas de preservação marginais aos cursos d'água e a localização da implantação de sistema de tratamento de efluentes, no que diz respeito a fontes difusas e pontuais, respectivamente, garantindo a assimilação de cargas poluidoras pelo corpo receptor.

A disponibilidade de um banco de dados atualizável referente a bacia do Rio Paraíba do Sul permite alimentar modelos de avaliação de cargas poluidoras associadas ao uso e ocupação do solo, bem como modelos de simulação da qualidade das águas.

Os inúmeros trabalhos já realizados na bacia, apesar de sua relevância e custo significativo, até então não proveram a bacia de banco de dados significativo que poderia ser resgatado naqueles que o sucedem, pois foram realizados num formato que permite apenas o resgate de alguns poucos mapas digitalizados.

Quando se trabalha com dados públicos, oriundos de fontes das mais diversas, a escolha inadequada de área de estudo pode inviabilizar a execução de um trabalho, não só por lacunas de dados, como pela falta de visão integrada das condições de contorno. Portanto ao se trabalhar com diferentes dados espaciais, como é o caso de bacias hidrográficas, que precisam ser associados, a utilização de Sistema de Informação Geográfica para análise preliminar, promovendo a superposição de Planos de Informação (layers) viabiliza a execução de trabalho, após a reunião dos dados primários numa base de dados de SIG. 
A partir da implementação desta metodologia é possível traçar cenários alternativos para auxiliar na tomada de decisão em relação à adoção das medidas de recuperação e preservação da qualidade das águas no âmbito de bacias hidrográficas.

Esta metodologia pode permitir a avaliação das regras operativas de reservatórios de regularização, sob o aspecto de melhoria das condições sanitárias do rio Paraíba do Sul

A recém anunciada implantação de sondas de monitoramento contínuo de qualidade da água pelo $\mathrm{CBH}$ - Paraíba do Sul, diferentemente da propalada identificação de cargas noturnas clandestinas, poderão auxiliar na avaliação das cargas de origem difusa, uma vez que registram as conseqüências de eventos pluviométricos, cujo run off é o principal meio de transporte das cargas difusas.

\section{Recomendações}

Ao se tratar de qualidade da água não se pode dissociar do aspecto de quantidade, nem tampouco do uso e ocupação do solo. Portanto o monitoramento destes aspectos devem necessariamente estar devidamente associados, ou seja, promover o monitoramento de qualidade buscando associar ao monitoramento da vazão, sendo que aonde não for viável, que se disponha de informações suficientes para a avaliação indireta, ou seja, através das unidades de avaliação de quantidade, as bacias ou sub-bacias hidrográficas. A mesma recomendação serve para o monitoramento da qualidade que apresenta repercussões diretas do uso e ocupação do solo de sua bacia, ou seja, deve estar ajustado a unidade responsável pelo uso e ocupação do solo (quando urbano, de competência municipal, por exemplo), sem dissociá-la das bacias hidrográficas.

Refinando ainda mais poderíamos ajustar os monitoramentos de qualidade de quantidade às aptidões de cada trecho da bacia, viabilizando assim uma avaliação mais adequadas das conseqüências do uso e ocupação do solo na qualidade da água. 
ANEXOS 
ANEXO 1 - Relação de sub-bacias de afluentes diretos do rio Paraíba do Sul em território paulista.

\begin{tabular}{|c|c|c|}
\hline $3_{13}$ & is & 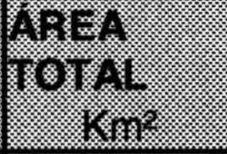 \\
\hline 1 & 1|R. PARAIBUNA & 1556,35 \\
\hline 2 & 2|R. PARAITINGA & 2693,03 \\
\hline 3 & 12C. CAMPO REDONDO & 16,89 \\
\hline 4 & 14|C. DE BRAGANÇA & 39,67 \\
\hline 5 & 29/R. DO SALTO & 111,07 \\
\hline 6 & 33C. SANTO ANTÔNIO & 2,85 \\
\hline 7 & 38|C. JATAÍ & 2,62 \\
\hline 8 & 42|RIB. PANTANHÃO & 22,50 \\
\hline 9 & 48R. CAPIVARI & 211,17 \\
\hline 10 & 50/R. VIRADOURO & 22,09 \\
\hline 11 & 58C. ITAMIRIM & 12,17 \\
\hline 12 & 61|RIB. GUMEATINGA & 79,35 \\
\hline 13 & 77)C. DA ANGOLA & 3,00 \\
\hline 14 & 81|C. DO TABUÃO & 13,92 \\
\hline 15 & 82|RIB. SANTA FÉ & 18,65 \\
\hline 16 & 92 C. FAZ. HARMONIA & 3,80 \\
\hline 17 & 101|RIB. DOS MONOS & 87,35 \\
\hline 18 & 106C. CAMPO GRANDE & 4,00 \\
\hline 19 & 107|C. VALE DA ALEGRIA & 1,22 \\
\hline 20 & 114|C. FAZ. DO MOTA & 1,52 \\
\hline 21 & 120|C. FAZ. CAIÇARA & 0,57 \\
\hline 22 & 125|RIB. PUTIM & 83,70 \\
\hline 23 & 139|RIB. GUARAREMA & 63,42 \\
\hline 24 & 141|R. COMPRIDO/ESTIVA & 15,40 \\
\hline 25 & 149RIB. ITAPETI & 56,97 \\
\hline 26 & 156C. DE BOM JESUS & 2,00 \\
\hline 27 & 157|RIB. SÃO SEBASTIÃO & 18,75 \\
\hline 28 & 163|C. DO BAIRRINHO & 7,90 \\
\hline 29 & 174|C. 4 RIBEIRAS & 12,00 \\
\hline 30 & 178|RIB. DA COLÔNIA & 13,25 \\
\hline 31 & 182|R. COMPRIDO & 49,54 \\
\hline 32 & 184|C. LIMOEIRO & 14,75 \\
\hline 33 & $186 / 21 B .00$ VIDOCA & 43,60 \\
\hline 34 & 188/R1B. . AVAPES & 14,55 \\
\hline 35 & 196 PIB. PUTINS & 44,50 \\
\hline 36 & 192 COMPLEXO HIDROL. & 12,25 \\
\hline 37 & 194 R. ALAMBAPI & 81.87 \\
\hline 38 & 196. C. DOS VEADOS & 10.17 \\
\hline 39 & 198R PARARANCABA & $71.5 \%$ \\
\hline
\end{tabular}




\begin{tabular}{|c|c|c|c|}
\hline$k^{2}=$ & 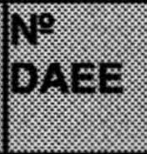 & 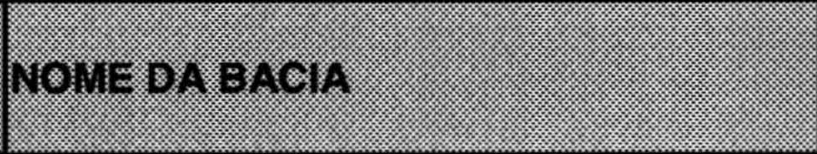 & 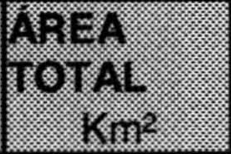 \\
\hline 40 & 206 & RIB. DA DIVISA & 61,57 \\
\hline 41 & 20 & C. DOS L EOEES & 5,37 \\
\hline 42 & 208 & RIB, MANOEL LITO & 16,02 \\
\hline 43 & 210 & RIB. DOS MUDOS & 46,16 \\
\hline 44 & 216 & C. GUAICARAVCAETANO & 27,21 \\
\hline 45 & 218 & RIB. CAÇAPAVA VELHA & 30,85 \\
\hline 46 & 220 & C. DA PONTE ALTA & 11,27 \\
\hline 47 & 222 & RIB. PIRACANGUA & 47,19 \\
\hline 48 & 224 & RIB. DO PINHÃO & 21,25 \\
\hline 49 & 226 & JUDEU & 17,17 \\
\hline 50 & 227 & RIB. VERMELHO & 4,80 \\
\hline 51 & 228 & RIB. DO MOINHO I - STA CRUZ & 9,50 \\
\hline 52 & 230 & RIB. DO MOINHO II - CONVENTO VELHO & 33,40 \\
\hline 53 & 232 & RIO UNA & 467,22 \\
\hline 54 & 234 & R. DA GALEGANANHANGUERA & 18,92 \\
\hline 55 & 236 & R. DO CORTUME & 81,57 \\
\hline 56 & 235 & RIB. JAGUARI & 1730,49 \\
\hline 57 & 238 & RIB. IPIRANGA & 53,80 \\
\hline 58 & 240 & RIB. CAPITUBA & 41,57 \\
\hline 59 & 244 & RIB. PIRATINI/SURDOS & 21,16 \\
\hline 60 & 245 & R. BUQUIRAIFERRÃO & 413,29 \\
\hline 61 & 246 & R. PIRAPITINGUI & 116,61 \\
\hline 62 & 248 & RIB. ITAGUAÇU & 10,57 \\
\hline 63 & 250 & RIB. DA CHÁCARA & 5,67 \\
\hline 64 & 255 & RIB. BUERATEMA & 8,92 \\
\hline 65 & 256 & RIB. DOS MOTAS & 98,04 \\
\hline 66 & 25 & C. FAZ, MONTE ALEGRE & 9,05 \\
\hline 67 & 258 & RIB. SÃO GONÇALO & 114,75 \\
\hline 68 & 268 & RIB. CASCUDOIBUTA & 31,32 \\
\hline 69 & 264 & RIB. SANTA RITA & 14,72 \\
\hline 78 & 265 & R1B. CABUSU & 46.1 .8 \\
\hline 71 & 268 & RIB. SÃO JOÃO & 6,00 \\
\hline 72 & 270 & RIB. FARROUPILHA & 15,72 \\
\hline 73 & $27 \%$ & RIB. IRIGUAOU & 38,85 \\
\hline 74 & 272 & RIB. TABUÃO & 77,95 \\
\hline 75 & $27 \varepsilon$ & C. DOS PASSOS & 15,40 \\
\hline 76 & 279 & RIB. TAPERUÇU & 20,82 \\
\hline 77 & 282 & RIB. CANAS & 75,34 \\
\hline 78 & 283 & RIB. DAS PITANGUEIRAS II & 22,32 \\
\hline 79 & 28 & RIB. DAS CANINHAS & 30,96 \\
\hline 80 & 287 & C. COMPRIDO & 11,15 \\
\hline 81 & 288 & RIB. DAS PITAS & 36,42 \\
\hline 82 & 289 & RIB. DOSMOTAS & 22,14 \\
\hline
\end{tabular}




\begin{tabular}{|c|c|c|c|}
\hline$N^{2}$ & $\begin{array}{l}\mathrm{N}^{\circ} \\
\mathrm{B} H \mathrm{Im}\end{array}$ & NOME BA BACH & 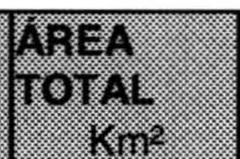 \\
\hline 83 & 290 & RIB. DA MINHOCA & 4,82 \\
\hline 84 & 294 & RIB DA BOCAINA & 251,36 \\
\hline 85 & 297 & RIB. DA SERRAGEM & 54,40 \\
\hline 86 & 298 & RIB. DAS PEDRAS & 14,29 \\
\hline 87 & 299 & R. PIRACUAMA & 156,09 \\
\hline 88 & 305 & RIB. DASPEDRAS/MANDU & 14,12 \\
\hline 89 & 306 & C. FAZ. VISTA VERDE & 1,80 \\
\hline 90 & 311 & RIB. DA PONTE ALTA & 40,85 \\
\hline 91 & 312 & C. SANTA TEREZINHA & 10,85 \\
\hline 92 & 313 & RIB. TETEQUERA/GRANDE & 131,92 \\
\hline 93 & 315 & C. DO ROSÁRIO & 1,74 \\
\hline 94 & 318 & C. SÃO DOMINGOS & 3,40 \\
\hline 95 & 321 & RIB. DOS BUENOS & 82,39 \\
\hline 96 & 325 & C. DO PUTIM & 25,10 \\
\hline 97 & 326 & C. DAS PITANGUEIRAS & 226,72 \\
\hline 98 & 327 & RIB. ÁGUA DOS NEVES & 8,62 \\
\hline 99 & 331 & RIB. GUARATINGUETÁ & 159,17 \\
\hline 100 & 332 & C. MUNICIPAL & 0,75 \\
\hline 101 & 334 & C. DO SERTÃO/CAMPO & 5,00 \\
\hline 102 & 343 & RIB. PIAGUI & 171,37 \\
\hline 103 & 348 & C. DA QUEIMADA & 6,15 \\
\hline 104 & 352 & C. DOS GREGOS/CANEQUINHA & 7,10 \\
\hline 105 & 353 & R. DAS POSSES/MACACOS & 38,09 \\
\hline 106 & 354 & C. DOS CORREIAS & 0,87 \\
\hline 107 & 355 & RIB. DA LIMEIRA & 62,07 \\
\hline 108 & 358 & C. DA DIVIDSA - MURANO & 1,95 \\
\hline 109 & 359 & C. DO CAMPINHO & 7,82 \\
\hline 110 & 362 & C. DO MORRO GRANDE & 5,45 \\
\hline 111 & 365 & C. BELA VISTA & 3,95 \\
\hline 112 & 366 & C. SANTANA & 5,30 \\
\hline 113 & 367 & C. AREADO & 5,35 \\
\hline 114 & 369 & C. DA AGUADA & 7,41 \\
\hline 115 & 372 & C. PIRUTINGA & 3,77 \\
\hline 116 & 376 & C. DA BARRA & 14,77 \\
\hline 117 & 389 & R. PIQUETE & 348,56 \\
\hline 118 & 396 & C. DA GRAMA & 23,47 \\
\hline 119 & 399 & C. DO PONTILHÃO & 13,40 \\
\hline 120 & 401 & RIB. DOS LOPES OU ÁGUA LIMPA & 60,22 \\
\hline 121 & 403 & C. LINDEIRO & 1,30 \\
\hline 122 & 407 & RIB. JACU & 83,87 \\
\hline 123 & 409 & C. JACUZINHO & 13,52 \\
\hline 124 & 413 & C. DAS VELHAS & 2,27 \\
\hline 125 & 428 & C. SANTA CLARA & 11,87 \\
\hline
\end{tabular}




\begin{tabular}{|c|c|c|c|}
\hline 30 & 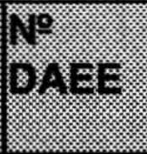 & 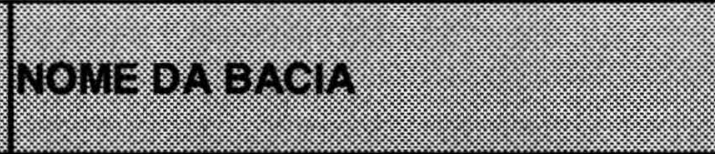 & 严 \\
\hline 126 & 430 & RIB. VERMELHO & 94,37 \\
\hline 127 & 432 & RIB. SANTANAN. GRANDE & 82,42 \\
\hline 128 & 437 & RIB. CLARO & 51,42 \\
\hline 129 & 439 & C. DA BARRINHA & 3,77 \\
\hline 130 & 451 & RIB. DO ENTUPIDO & 27,60 \\
\hline 131 & $45 s$ & RIB. VERDE & 7,07 \\
\hline 132 & 463 & C. DA CASCATA I & 6,75 \\
\hline 133 & 467 & C. DA CASCATA II & 2,02 \\
\hline 134 & $46 s$ & RIB. DAS CRUZES & 61,20 \\
\hline 135 & 471 & C. DA PONTE QUEBRADA & 1,25 \\
\hline 136 & 475 & C. DAS MARRECAS & 4,00 \\
\hline 137 & 481 & RIB. DO SALTO & 23,00 \\
\hline 138 & 180 & S. N. (vulto Córrego Seco) & 6,25 \\
\hline 139 & 197 & COMPL. HIDROL. (vulgo Tanquinho) & 32,04 \\
\hline \multicolumn{4}{|c|}{ Área total: 11955,12} \\
\hline
\end{tabular}

Fonte: Relatório Zero (CPTI 2000a) e Plano de Bacia da UGRHI-2 (CPTI 2000b). 


\section{ANEXO 2 - POSTOS FLUVIOMÉTRICOS}

Postos Fluviométricos contendo dados recentes (no mínimo até 2002), instalados na bacia do Paraíba do Sul no estado de São Paulo, bem como sua localização geográfica.

\begin{tabular}{|c|c|c|c|}
\hline Codigo & 58030000 & Codigo & 58040000 \\
\hline Nome & ESTRADA DO CUNHA & \multirow{2}{*}{ Nome } & \multirow{2}{*}{$\begin{array}{l}\text { SÃO LUIZ DO } \\
\text { PARAITINGA - SLP }\end{array}$} \\
\hline Código Adicional & $-\quad+2010$ & & \\
\hline \multirow[b]{2}{*}{ Bacia } & \multirow{2}{*}{$\begin{array}{l}\text { Atlântico, Trecho Leste } \\
\text { (5) }\end{array}$} & Código Adicional & - \\
\hline & & \multirow{2}{*}{ Bacia } & \multirow{2}{*}{$\begin{array}{l}\text { Atlântico, Trecho Leste } \\
(5)\end{array}$} \\
\hline \multirow{2}{*}{ Sub-bacia } & \multirow{2}{*}{$\begin{array}{l}\text { RIO PARAIBA DO SUL } \\
(58)\end{array}$} & & \\
\hline & & \multirow{2}{*}{ Sub-bacia } & \multirow{2}{*}{$\begin{array}{l}\text { RIO PARAIBA DO SUL } \\
(58)\end{array}$} \\
\hline Rio & RIO PARAITINGA & & \\
\hline Estado & SÃO PAULO & Rio & RIO PARAITINGA \\
\hline Municipio & CUNHA & Estado & SÃO PAULO \\
\hline Responsável & ANA & Municipio & $\begin{array}{l}\text { SÃO LUIS DO } \\
\text { PARAITINGA }\end{array}$ \\
\hline Operadora & CPRM & Responsável & ANA \\
\hline Latitude & $-22: 59: 45$ & Operadora & CPRM \\
\hline Longitude & $-45: 2: 30$ & Latitude & $-23: 19: 30$ \\
\hline Altitude $(\mathrm{m})$ & 780 & Longitude & $-45: 18: 20$ \\
\hline \multirow[t]{2}{*}{ Área de Drenagem $(\mathrm{km} 2)$} & 735 & \multirow{2}{*}{$\begin{array}{l}\text { Altitude }(\mathrm{m}) \\
\text { Area de Drenagem }(\mathrm{km} 2)\end{array}$} & \multirow{2}{*}{$\begin{array}{l}730 \\
1920\end{array}$} \\
\hline & & & \\
\hline Código & 58060000 & Codigo & 58099000 \\
\hline Nome & PONTE ALTA 1 & Nome & SANTA BRANCA \\
\hline Código Adicional & - & Código Adicional & PA010 \\
\hline Bacia & $\begin{array}{l}\text { Atlântico, Trecho Leste } \\
(5)\end{array}$ & Bacla & $\begin{array}{l}\text { Atlântico, Trecho Leste } \\
(5)\end{array}$ \\
\hline Sub-bacia & $\begin{array}{l}\text { RIO PARAIBA DO SUL } \\
(58)\end{array}$ & Sub-bacia & $\begin{array}{l}\text { RIO PARAIBA DO SUL } \\
(58)\end{array}$ \\
\hline Rio & RIO PARAIBUNA & $\mathrm{Rio}$ & RIO PARAIBA DO SUL \\
\hline Estado & SÃO PAULO & Estado & SÃO PAULO \\
\hline \multirow{2}{*}{ Municipio } & SÃO LUIS DO & Municipio , & SANTA BRANCA \\
\hline & PARAITINGA & Responsável & ANA \\
\hline Responsável & ANA & Operadora & CPRM \\
\hline Operadora & CPRM & Lattude & $-23: 22: 8$ \\
\hline Latitude & $-23: 19: 44$ & Longitude & $-45: 54: 0$ \\
\hline Longitude & $-45: 8: 38$ & Altitude $(m)$, & 573 \\
\hline Altitude $(m)$, & 888 & Area de Drenagem $(\mathrm{km} 2)$ & 4930 \\
\hline Area de Drenagem (km2) & 276 & & \\
\hline Codigo & 58110002 & Código & 58142200 \\
\hline Nome & JACAREI - SAAE & Nome & BUQUIRINHA 2 \\
\hline Código Adicional & $V-1-020$ & Código Adicional & - \\
\hline Bacia & $\begin{array}{l}\text { Atlântico, Trecho Leste } \\
\text { (5) }\end{array}$ & Bacia & $\begin{array}{l}\text { Atlântico, Trecho Leste } \\
\text { (5) }\end{array}$ \\
\hline Sub-bacia & $\begin{array}{l}\text { RIO PARAIBA DO SUL } \\
(58)\end{array}$ & Sub-bacia & $\begin{array}{l}\text { RIO PARAIBA DO SUL } \\
(58)\end{array}$ \\
\hline Rio & RIO PARAIBA DO SUL & Rio & RIO BUQUIRA OU FERRÃO \\
\hline Estado & SÃO PAULO & Estado & SÃO PAULO \\
\hline
\end{tabular}




\begin{tabular}{|c|c|c|c|}
\hline Municipio & JACAREI & Municipio & SÃO JOSÉ DOS CAMPOS \\
\hline Responsável & ANA & Responsável & ANA \\
\hline Operadora & CPRM & Operadora & FURNAS \\
\hline Latitude & $-23: 18: 38$ & Latitude & $-23: 4: 30$ \\
\hline Longitude & $-45: 58: 16$ & Longitude & $-45: 54: 24$ \\
\hline Altitude $(m)$ & 570 & Altitude $(\mathrm{m})$ & 575 \\
\hline Area de Drenagem (km2) & 5690 & Area de Drenagem $(\mathrm{km} 2)$ & 406 \\
\hline Código & 58183000 & Código. & 58204000 \\
\hline Nome & PINDAMONHANGABA & Nome & GUARATINGUETA \\
\hline Código Adicional & INPE & Código Adicional & - \\
\hline Bacia & $\begin{array}{l}\text { Atlântico, Trecho Leste } \\
\text { (5) }\end{array}$ & Bacia & $\begin{array}{l}\text { Atlântico, Trecho Leste } \\
\text { (5) }\end{array}$ \\
\hline Sub-bacia & $\begin{array}{l}\text { RIO PARAIBA DO SUL } \\
(58)\end{array}$ & Sub-bacia & $\begin{array}{l}\text { RIO PARAIBA DO SUL } \\
(58)\end{array}$ \\
\hline Rio & RIO PARAIBA DO SUL & Rio & RIO PARAIBA DO SUL \\
\hline Estado & SÃO PAULO & Estado & SÃO PAULO \\
\hline Municipio & PINDAMONHANGABA & Municipio & GUARATINGUETA \\
\hline Responsável & ANA & Responsável & ANA \\
\hline Operadora & FURNAS & Operadora & FURNAS \\
\hline Latitude & $-22: 54: 40$ & Latitude & $-22: 48: 44$ \\
\hline Longitude & $-45: 28: 13$ & Longitude & $-45: 10: 57$ \\
\hline Altitude $(\mathrm{m})$ & 525 & Altitude $(\mathrm{m})$ & 520 \\
\hline Area de Drenagem (km2) & 9576 & Area de Drenagem $(\mathrm{km} 2)$ & 10617 \\
\hline Código & 58220000 & Código & 58235000 \\
\hline Nome & FAZENDA SANTA CLARA & Nome & QUELUZ \\
\hline Código Adicional & - & Códiga Adicional & RESOLUÇAO 396 \\
\hline Bacia & $\begin{array}{l}\text { Atlântico, Trecho Leste } \\
(5)\end{array}$ & Bacia & $\begin{array}{l}\text { Atlântico, Trecho Leste } \\
(5)\end{array}$ \\
\hline Sub-bacia & $\begin{array}{l}\text { RIO PARAIBA DO SUL } \\
(58)\end{array}$ & Sub-bacia & $\begin{array}{l}\text { RIO PARAIBA DO SUL } \\
(58)\end{array}$ \\
\hline Rio & RIO BOCAINA & Rio & RIO PARAIBA DO SUL \\
\hline Estado & SÃO PAULO & Estado & SÃO PAULO \\
\hline Municipio & CACHOEIRA PAULISTA & Municipio & QUELUZ \\
\hline Responsável & ANA & Responsável & ANA \\
\hline Operadora & FURNAS & Operadora & FURNAS \\
\hline Latitude & $-22: 41: 32$ & Latitude & $-22: 32: 25$ \\
\hline Longitude & $-44: 58: 28$ & Longitude & $-44: 46: 23$ \\
\hline Altitude $(\mathrm{m})$ & 550 & Altitude $(\mathrm{m})$ & 464 \\
\hline Area de Drenagem $(\mathrm{km} 2)$ & 202 & Area de Drenagem $(\mathrm{km} 2)$ & 12749 \\
\hline
\end{tabular}

Observacão: o primeiro digito, no caso 5, refere-se a divisão em grandes bacias nacionais, que neste caso é a bacia do Atlântico Sul, e a sua junção com o segundo, formando o numero 58 refere-se a sub bacia do Paraíba do Sul 
ANEXO 3 - DADOS DE QUALIDADE DAS ÁGUAS DO RIO PARAÍBA DO SUL (CETESB 2004)

\begin{tabular}{|c|c|c|c|c|c|c|c|c|c|c|}
\hline \multicolumn{11}{|c|}{ Resultados dos parâmetros e indicadores de qualidade das águas - CETESB } \\
\hline UGRHI: & \multicolumn{4}{|c|}{ PARAIBA DO SUL } & & Classe : & \multicolumn{2}{|c|}{2} & \multirow{2}{*}{ 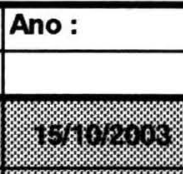 } & \multirow{2}{*}{ 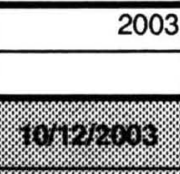 } \\
\hline 9 & 4\% & (cosicis & \multicolumn{2}{|c|}{4} & 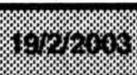 & (1/ & 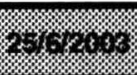 & 19.8. & & \\
\hline (4) & (1) & & & & / & (2) & & & & \\
\hline \multirow[t]{9}{*}{ Chuva 24h } & - & & \multirow[t]{9}{*}{ PARB } & 02100 & Sim & Não & Não & Não & Não & Sim \\
\hline & & & & 02200 & Não & Não & Não & Não & Não & Não \\
\hline & & & & 02300 & Sim & Não & Não & Não & Não & Sim \\
\hline & & & & 02310 & Sim & Não & Não & Não & Não & Sim \\
\hline & & & & 02400 & Não & Não & Não & Não & Não & Não \\
\hline & & & & 02490 & Sim & Não & Não & Não & Não & Sim \\
\hline & & & & 02600 & Sim & Não & Não & Não & Não & Sim \\
\hline & & & & 02700 & Sim & Não & Não & Não & Não & Sim \\
\hline & & & & 02900 & Sim & Não & Não & Não & Não & Sim \\
\hline \multirow[t]{9}{*}{ Coloração } & & & \multirow[t]{9}{*}{ PARB } & 02100 & Amarela & Marrom & Verde & Verde & Marrom & Verde \\
\hline & & & & 02200 & Marrom & Verde & Verde & $\begin{array}{c}\text { Transparent } \\
\mathrm{e}\end{array}$ & Amarela & Transparente \\
\hline & & & & 02300 & Marrom & Marrom & Marrom & Verde & Marrom & Marrom \\
\hline & & & & 02310 & Marrom & Verde & Marrom & Verde & Marrom & Marrom \\
\hline & & & & 02400 & Marrom & Verde & Verde & Verde & Amarela & Transparente \\
\hline & & & & 02490 & Marrom & Marrom & Verde & Verde & Amarela & Transparente \\
\hline & & & & 02600 & Marrom & Marrom & Amarela & Verde & Amarela & Amarela \\
\hline & & & & 02700 & Marrom & Marrom & Verde & Verde & Amarela & Transparente \\
\hline & & & & 02900 & Marrom & Amarela & Verde & Verde & Amarela & Transparente \\
\hline \multirow[t]{6}{*}{$\mathrm{pH}$} & \multirow[t]{6}{*}{ U.pH } & \multirow[t]{6}{*}{6 e 9} & \multirow[t]{6}{*}{ PARB } & 02100 & 7,3 & 7 & 7,6 & 6,1 & 7,1 & 6,95 \\
\hline & & & & 02200 & 6,7 & 7 & 7 & 7,2 & 7,1 & 6,8 \\
\hline & & & & 02300 & 7 & 6,8 & 7,2 & 6,8 & 7,2 & 6,22 \\
\hline & & & & 02310 & 6,9 & 6,9 & 7,4 & 7 & 7,3 & 6 \\
\hline & & & & 02400 & 6,3 & 6,6 & 6,6 & 6,5 & 6,6 & 6,7 \\
\hline & & & & 02490 & 6,6 & 6,2 & 6 & 6,6 & 6,5 & 6,7 \\
\hline
\end{tabular}




\begin{tabular}{|c|c|c|c|c|c|c|c|c|c|c|}
\hline \multicolumn{11}{|c|}{ Resultados dos parâmetros e indicadores de qualidade das águas - CETESB } \\
\hline UGRHI: & \multicolumn{3}{|c|}{ PARAIBA DO SUL } & & & Classe: & \multicolumn{2}{|c|}{2} & \multirow{2}{*}{ 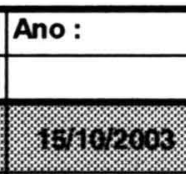 } & 2003 \\
\hline 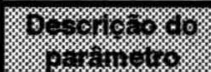 & 8: 1 in. & (6) & \multicolumn{2}{|c|}{$40 \%$} & 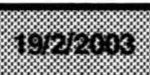 & 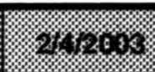 & 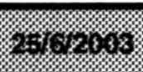 & 184800 & & 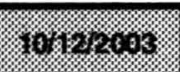 \\
\hline & & & & 02600 & 6,7 & 6,2 & 6,1 & 6,6 & 6,4 & 6,8 \\
\hline & & & & 02700 & 6,9 & 6,3 & 6,1 & 6,6 & 6,5 & 6,8 \\
\hline & & & & 02900 & 6,9 & 6,6 & 6,5 & 6,8 & 6,7 & 7 \\
\hline \multirow[t]{9}{*}{ Temp. Água } & \multirow[t]{9}{*}{${ }^{\circ} \mathrm{C}$} & & \multirow[t]{9}{*}{ PARB } & 02100 & 25 & 23 & 19 & 20 & 22 & 24 \\
\hline & & & & 02200 & 25 & 24 & 20 & 18 & 21,8 & 24 \\
\hline & & & & 02300 & 25 & 23 & 20 & 20 & 22 & 25 \\
\hline & & & & 02310 & 26 & 24 & 22 & 22 & 22 & 25 \\
\hline & & & & 02400 & 24 & 25 & 21 & 18 & 21,3 & 24 \\
\hline & & & & 02490 & 26 & 25 & 20 & 18 & 19 & 24 \\
\hline & & & & 02600 & 25,5 & 25 & 19 & 17 & 18 & 23 \\
\hline & & & & 02700 & 25,5 & 25 & 18 & 17 & 19 & 22 \\
\hline & & & & 02900 & 25 & 24 & 18 & 16 & 18 & 22 \\
\hline \multirow[t]{9}{*}{ Temp. Ar } & ${ }^{\circ} \mathrm{C}$ & & \multirow[t]{9}{*}{ PARB } & 02100 & 27 & 28 & 26 & 25 & 23 & 26 \\
\hline & & & & 02200 & 25 & 23 & 21 & 20 & 27 & 32 \\
\hline & & & & 02300 & 27 & 27 & 25 & 24 & 22 & 26 \\
\hline & & & & 02310 & 26 & 27 & 25 & 25 & 21 & 26 \\
\hline & & & & 02400 & 23 & 31 & 25 & 26 & 27 & 32 \\
\hline & & & & 02490 & 27 & 31 & 26 & 27 & 23 & 28 \\
\hline & & & & 02600 & 27 & 25 & 21 & 20 & 17 & 22 \\
\hline & & & & 02700 & 28,5 & 26 & 18 & 18 & 18 & 21 \\
\hline & & & & 02900 & 26 & 25 & 14 & 15 & 16 & 20 \\
\hline 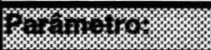 & \multicolumn{2}{|c|}{ 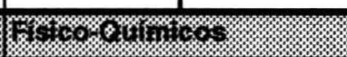 } & & & 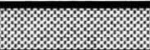 & & 8 & 84 & \% & \\
\hline \multirow[t]{6}{*}{ Absorb. no UV } & $\pi$ & & \multirow[t]{6}{*}{ PARB } & 02100 & & & & & & \\
\hline & & & & 02200 & 0,133 & 0,128 & 0,083 & 0,083 & 0,126 & 0,085 \\
\hline & & & & 02300 & & & & & & \\
\hline & & & & 02310 & 0,136 & 0,138 & 0,083 & 0,085 & 0,122 & 0,122 \\
\hline & & & & 02400 & & & & & & \\
\hline & & & & 02490 & 0,169 & 0,134 & 0,088 & 0,079 & 0,13 & 0,172 \\
\hline
\end{tabular}


Resultados dos parâmetros e indicadores de qualidade das águas - CETESB

\begin{tabular}{|c|c|c|c|c|c|c|c|c|c|c|}
\hline UGRHI: & \multicolumn{3}{|c|}{ PARAIBA DO SUL } & & & Classe: & \multicolumn{2}{|c|}{2} & Ano: & 2003 \\
\hline 3. & 多4 & 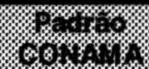 & \multicolumn{2}{|c|}{$4 \%$} & 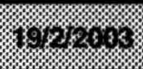 & \% & 1356. & 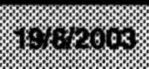 & 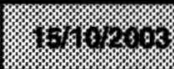 & 4 \\
\hline & & & & 02600 & 0,192 & 0,129 & 0,089 & 0,088 & 0,113 & 0,181 \\
\hline & & & & 02700 & & & & & & \\
\hline & & & & 02900 & & & & & & \\
\hline \multirow[t]{10}{*}{ Alumínio } & $\mathrm{mg} / \mathrm{L}$ & 0,1 & JAGI & 02900 & 3,8 & 0,47 & 0,09 & 0,25 & 17 & 0,41 \\
\hline & & & \multirow[t]{9}{*}{ PARB } & 02100 & 1,2 & 0,93 & 0,16 & 09 & 0.2 & 0,29 \\
\hline & & & & 02200 & 2,1 & 1,06 & 0,62 & 0,52 & 0,45 & 0,81 \\
\hline & & & & 02300 & 3,4 & 1,15 & 1,27 & 0,53 & 1,5 & 0.85 \\
\hline & & & & 02310 & 1,7 & 0.69 & 1,02 & 0,57 & 1 & 1,06 \\
\hline & & & & 02400 & 1,9 & 0,68 & 0.84 & 0,56 & 1,2 & 0,77 \\
\hline & & & & 02490 & 2,1 & 0,71 & 0,61 & 1,1 & 1,7 & 3.19 \\
\hline & & & & 02600 & 2 & 1,1 & 1,74 & 0,72 & 4,7 & 1,54 \\
\hline & & & & 02700 & 1,7 & 1,17 & 109 & 0,94 & 4,4 & 1,8 \\
\hline & & & & 02900 & 1,4 & 4,66 & 1,48 & 0,84 & 49 & 3.48 \\
\hline & & & & & & & & & & \\
\hline \multirow[t]{9}{*}{ Cádmio } & $\mathrm{mg} / \mathrm{L}$ & 0,001 & \multirow[t]{9}{*}{ PARB } & 02100 & $i<0,005$ & $i<0,005$ & $i<0,002$ & $\mathrm{i}<0,002$ & $i<0,002$ & $i<0,002$ \\
\hline & & & & 02200 & $\mathrm{i}<0,005$ & $i<0,005$ & $\mathrm{i}<0,002$ & $<0,001$ & $i<0,002$ & $i<0,002$ \\
\hline & & & & 02300 & $i<0,005$ & $i<0,005$ & $\mathrm{i}<0,002$ & $<0,001$ & $\mathrm{i}<0,002$ & $i<0,002$ \\
\hline & & & & 02310 & $\mathrm{i}<0,005$ & $\mathrm{i}<0,005$ & $i<0,002$ & $<0,001$ & $\mathrm{i}<0,002$ & $i<0,002$ \\
\hline & & & & 02400 & $\mathrm{i}<0,005$ & $\mathrm{i}<0,005$ & $\mathrm{i}<0,002$ & $<0,001$ & $\mathrm{i}<0,002$ & $i<0,002$ \\
\hline & & & & 02490 & $\mathrm{i}<0,005$ & $\mathrm{i}<0,005$ & $\mathrm{i}<0,002$ & $\mathrm{i}<0,002$ & $\mathrm{i}<0,002$ & $\mathrm{i}<0,002$ \\
\hline & & & & 02600 & $i<0,005$ & $i<0,005$ & $i<0,002$ & $<0,001$ & $i<0,002$ & $i<0,002$ \\
\hline & & & & 02700 & $\mathrm{i}<0,005$ & $\mathrm{i}<0,005$ & $i<0,002$ & $<0,001$ & $i<0,002$ & $i<0,002$ \\
\hline & & & & 02900 & $i<0,005$ & $i<0,005$ & $i<0,002$ & $<0,001$ & $i<0,002$ & $i<0,002$ \\
\hline Chumbo & $\mathrm{mg} / \mathrm{L}$ & 0,03 & \multirow[t]{3}{*}{ PARB } & 02100 & $\mathrm{i}<0,04$ & $\mathrm{i}<0,04$ & $<0,02$ & $<0,02$ & $<0,02$ & $<0,02$ \\
\hline \multicolumn{2}{|c|}{$\begin{array}{l}\text { Obs: Limite de deteç̧ão da } \\
\text { metodologia superior ao } \\
\text { limite legal }\end{array}$} & 0,01 & & 02200 & $i<0,04$ & $i<0,04$ & $<0,02$ & $<0,02$ & $<0,02$ & $<0,02$ \\
\hline & & & & 02300 & $i<0,04$ & $i<0,04$ & $<0,02$ & $<0,02$ & $<0,02$ & $<0,02$ \\
\hline
\end{tabular}




\begin{tabular}{|c|c|c|c|c|c|c|c|c|c|c|}
\hline \multicolumn{11}{|c|}{ Resultados dos parâmetros e indicadores de qualidade das águas - CETESB } \\
\hline UGRHI: & \multicolumn{3}{|c|}{ PARAIBA DO SUL } & & & Classe: & \multicolumn{2}{|c|}{2} & \multirow[t]{2}{*}{ Ano: } & \multirow[t]{2}{*}{2003} \\
\hline$\cdots$ & & & & & & & & & & \\
\hline \multirow[t]{7}{*}{$\begin{array}{l}\text { Descrição do } \\
\text { parâmetro }\end{array}$} & \multirow[t]{2}{*}{ Unidade } & $\begin{array}{l}\text { Padrão } \\
\text { CONAMA }\end{array}$ & \multicolumn{2}{|c|}{ Posto de Monitoramento } & \multirow{2}{*}{$\frac{19 / 2 / 2003}{i<0,04}$} & \multirow{2}{*}{$\frac{2 / 4 / 2003}{i<0,04}$} & \multirow{2}{*}{$\frac{25 / 6 / 2003}{<0,02}$} & \multirow{2}{*}{$\frac{19 / 8 / 2003}{<0,02}$} & $15 / 10 / 2003$ & $10 / 12 / 2003$ \\
\hline & & & & 02310 & & & & & $<0,02$ & $<0,02$ \\
\hline & & & & 02400 & $\mathrm{i}<0,04$ & $\mathrm{i}<0,04$ & $<0,02$ & $<0,02$ & $<0,02$ & $<0,02$ \\
\hline & & & & 02490 & $i<0,04$ & $i<0,04$ & $<0,02$ & $<0,02$ & $<0,02$ & $<0,02$ \\
\hline & & & & 02600 & $i<0,04$ & $i<0,04$ & $<0,02$ & $<0,02$ & $<0,02$ & $<0,02$ \\
\hline & & & & 02700 & $i<0,04$ & $i<0,04$ & $<0,02$ & $<0,02$ & $<0,02$ & $<0,02$ \\
\hline & & & & 02900 & $i<0,04$ & $i<0,04$ & $<0,02$ & $<0,02$ & $<0,02$ & $<0,02$ \\
\hline \multirow[t]{9}{*}{ Cloreto Total } & $\mathrm{mg} / \mathrm{L}$ & 250 & \multirow[t]{9}{*}{ PARB } & 02100 & 1,8 & 6,9 & 2 & 2,3 & 1,9 & 2,1 \\
\hline & & & & 02200 & 5,9 & 6,8 & 4 & 5,3 & 3,7 & 4,7 \\
\hline & & & & 02300 & 8,5 & 4,8 & 4,1 & 3 & 4,9 & 6,4 \\
\hline & & & & 02310 & 7,6 & 7,2 & 4,3 & 5,4 & 5,4 & 7,4 \\
\hline & & & & 02400 & 6,3 & 7,3 & 4,7 & 5,5 & 5,2 & 7,5 \\
\hline & & & & 02490 & 6,8 & 8,4 & 5,2 & 4,5 & 5,7 & 7 \\
\hline & & & & 02600 & 8,1 & 9,7 & 5,5 & 6,7 & 6,7 & 7,7 \\
\hline & & & & 02700 & 7,6 & 8,5 & 5,7 & 6,6 & 6,7 & 9 \\
\hline & & & & 02900 & 7,4 & 7,6 & 5,6 & 7,4 & 4,5 & 8,1 \\
\hline \multirow[t]{9}{*}{ Cobre } & $\mathrm{mg} / \mathrm{L}$ & 0,02 & \multirow[t]{9}{*}{ PARB } & 02100 & $<0,01$ & $<0,01$ & $<0,004$ & $<0,004$ & $<0,004$ & $<0,004$ \\
\hline & & 0,009 & & 02200 & $<0,01$ & $<0,01$ & $<0,004$ & $<0,002$ & $<0,004$ & $<0,004$ \\
\hline & & Cu dissolv. & & 02300 & $<0,01$ & $<0,01$ & $<0,004$ & $<0,002$ & $<0,004$ & $<0,004$ \\
\hline & & & & 02310 & $<0,01$ & $<0,01$ & $<0,004$ & $<0,002$ & $<0,004$ & $<0,004$ \\
\hline & & & & 02400 & $<0,01$ & $<0,01$ & $<0,004$ & $<0,002$ & 0,004 & $<0,004$ \\
\hline & & & & 02490 & $<0,01$ & $<0,01$ & $<0,004$ & 0,004 & $<0,004$ & $<0,004$ \\
\hline & & & & 02600 & $<0,01$ & $<0,01$ & $<0,004$ & $<0,002$ & $<0,004$ & $<0,004$ \\
\hline & & & & 02700 & $<0,01$ & $<0,01$ & $<0,004$ & $<0,002$ & $<0,004$ & $<0,004$ \\
\hline & & & & 02900 & $<0,01$ & $<0,01$ & $<0,004$ & $<0,002$ & $<0,004$ & $<0,004$ \\
\hline \multirow[t]{3}{*}{ COD } & $\mathrm{mg} / \mathrm{L}$ & & \multirow[t]{3}{*}{ PARB } & 02100 & & & & & & \\
\hline & & & & 02200 & 5,19 & 4,83 & 4,61 & 3,93 & 5,24 & 3,25 \\
\hline & & & & 02300 & & & & & & \\
\hline
\end{tabular}




\begin{tabular}{|c|c|c|c|c|c|c|c|c|c|c|}
\hline \multicolumn{11}{|c|}{ Resultados dos parâmetros e indicadores de qualidade das águas - CETESB } \\
\hline UGRHI: & \multicolumn{3}{|c|}{ PARAIBA DO SUL } & & & Classe : & 2 & & Ano: & 2003 \\
\hline \multirow{7}{*}{$\begin{array}{c}\text { Descrição do } \\
\text { parâmetro }\end{array}$} & \multirow[t]{2}{*}{ Unidade } & $\begin{array}{l}\text { Padrão } \\
\text { CONAMA }\end{array}$ & \multicolumn{2}{|c|}{ Posto de Monitoramento } & \multirow{2}{*}{$\frac{19 / 2 / 2003}{4,91}$} & \multirow{2}{*}{$\frac{2 / 4 / 2003}{5}$} & \multirow{2}{*}{$\frac{25 / 6 / 2003}{3,68}$} & \multirow{2}{*}{$\frac{19 / 8 / 2003}{3,69}$} & \multirow{2}{*}{$\frac{15 / 10 / 2003}{3,95}$} & \multirow{2}{*}{$\frac{10 / 12 / 2003}{3,88}$} \\
\hline & & & & 02310 & & & & & & \\
\hline & & & & 02400 & & & & & & \\
\hline & & & & 02490 & 4,74 & 5,28 & 4,96 & 4,52 & 5,33 & 4,73 \\
\hline & & & & 02600 & 5,55 & 5,88 & 4,89 & 4,54 & 6,62 & 6,6 \\
\hline & & & & 02700 & & & & & & \\
\hline & & & & 02900 & & & & & & \\
\hline \multirow[t]{9}{*}{ Condutividade } & $\mu \mathrm{S} / \mathrm{cm}$ & & \multirow[t]{9}{*}{ PARB } & 02100 & 41 & 36 & 33 & 32 & 37 & 34 \\
\hline & & & & 02200 & 109 & 109 & 68 & 84 & 115 & 84 \\
\hline & & & & 02300 & 120 & 129 & 74 & 99 & 107 & 122 \\
\hline & & & & 02310 & 127 & 130 & 76 & 100 & 110 & 125 \\
\hline & & & & 02400 & 102 & 115 & 77 & 83 & 97 & 118 \\
\hline & & & & 02490 & 105 & 121 & 76 & 91 & 102 & 116 \\
\hline & & & & 02600 & 115 & 123 & 82 & 101 & 107 & 117 \\
\hline & & & & 02700 & 114 & 116 & 83 & 108 & 110 & 115 \\
\hline & & & & 02900 & 105 & 105 & 90 & 100 & 93 & 92 \\
\hline \multirow[t]{9}{*}{ Cromo Total } & $\mathrm{mg} / \mathrm{L}$ & 0,05 & \multirow[t]{9}{*}{ PARB } & 02100 & $<0,05$ & $<0,005$ & $<0,002$ & 0,002 & 0,002 & $<0,002$ \\
\hline & & & & 02200 & $<0,005$ & $<0,005$ & $<0,002$ & $<0,002$ & 0,002 & $<0,002$ \\
\hline & & & & 02300 & $<0,005$ & $<0,005$ & $<0,002$ & $<0,002$ & 0,002 & $<0,002$ \\
\hline & & & & 02310 & $<0,005$ & $<0,005$ & $<0,002$ & $<0,002$ & $<0,002$ & $<0,002$ \\
\hline & & & & 02400 & $<0,005$ & $<0,005$ & $<0,002$ & $<0,002$ & 0,004 & $<0,002$ \\
\hline & & & & 02490 & $<0,005$ & $<0,005$ & $<0,002$ & $<0,002$ & 0,002 & $<0,002$ \\
\hline & & & & 02600 & $<0,005$ & $<0,005$ & $<0,002$ & $<0,002$ & 0,004 & $<0,002$ \\
\hline & & & & 02700 & $<0,005$ & $<0,005$ & $<0,002$ & $<0,002$ & 0,004 & $<0,002$ \\
\hline & & & & 02900 & $<0,005$ & $<0,005$ & $<0,002$ & $<0,002$ & 0,004 & $<0,002$ \\
\hline \multirow[t]{3}{*}{ DBO $(5,20)$} & $\mathrm{mg} / \mathrm{L}$ & 5 & \multirow[t]{3}{*}{ PARB } & 02100 & 1 & 1 & 1 & 1 & 1 & 1 \\
\hline & & & & 02200 & 1 & 1 & 1 & 1 & 1 & 1,7 \\
\hline & & & & 02300 & 1 & 1 & 1 & 1 & 2 & 1,8 \\
\hline
\end{tabular}




\begin{tabular}{|c|c|c|c|c|c|c|c|c|c|c|}
\hline \multicolumn{11}{|c|}{ Resultados dos parâmetros e indicadores de qualidade das águas - CETESB } \\
\hline UGRHI: & \multicolumn{3}{|c|}{ PARAIBA DO SUL } & & & Classe : & \multicolumn{2}{|c|}{2} & \multirow{3}{*}{\begin{tabular}{|l|} 
Ano: \\
$15 / 10 / 2003$ \\
\end{tabular}} & \multirow{3}{*}{$\begin{array}{r}2003 \\
10 / 12 / 2003 \\
\end{array}$} \\
\hline$\cdots$ & & & & & & & & & & \\
\hline \multirow[t]{7}{*}{$\begin{array}{c}\text { Descrição do } \\
\text { parâmetro }\end{array}$} & Unidade & $\begin{array}{l}\text { Padrão } \\
\text { CONAMA }\end{array}$ & \multicolumn{2}{|c|}{ Posto de Monitoramento } & 19/2/2003 & 2/4/2003 & 25/6/2003 & $19 / 8 / 2003$ & & \\
\hline & & & & 02310 & 1 & 1 & 1 & 2 & 1 & 1,9 \\
\hline & & & & 02400 & 1 & 1 & 1 & 2 & 2 & 1,7 \\
\hline & & & & 02490 & 1 & 1 & 1 & 1 & 1 & 1,8 \\
\hline & & & & 02600 & 2 & 3 & 2 & 2 & 1 & 2,2 \\
\hline & & & & 02700 & 1 & 1 & 1 & 1 & 2 & 2,7 \\
\hline & & & & 02900 & 1 & 2 & 1 & 2 & 2 & 1 \\
\hline \multirow[t]{10}{*}{ DQO } & $\mathrm{mg} / \mathrm{L}$ & & JAGI & 02900 & 7 & 4 & $\overline{4}$ & 4 & 4 & 7 \\
\hline & & & \multirow[t]{9}{*}{ PARB } & 02100 & 4 & 4 & 4 & 4 & 4 & 7 \\
\hline & & & & 02200 & 7 & 4 & 4 & 11 & 7 & 14 \\
\hline & & & & 02300 & 7 & 4 & 4 & 4 & 7 & 18 \\
\hline & & & & 02310 & 7 & 4 & 4 & 4 & 7 & 11 \\
\hline & & & & 02400 & 7 & 4 & 4 & 4 & 11 & 18 \\
\hline & & & & 02490 & 7 & 13 & 11 & 4 & 22 & 18 \\
\hline & & & & 02600 & 14 & 17 & 11 & 4 & 14 & 18 \\
\hline & & & & 02700 & 4 & 4 & 11 & 4 & 18 & 22 \\
\hline & & & & 02900 & 4 & 10 & 11 & 4 & 18 & 18 \\
\hline \multirow[t]{9}{*}{ Fenóis } & $\overline{m g} / \mathrm{L}$ & 0,001 & \multirow[t]{9}{*}{ PARB } & 02100 & $<0,001$ & $<0,001$ & $<0,001$ & $<0,001$ & $<0,001$ & $<0,001$ \\
\hline & & 0,003 & & 02200 & $<0,001$ & $<0,001$ & $<0,001$ & $<0,001$ & $<0,001$ & $<0,001$ \\
\hline & & & & 02300 & $<0,001$ & $<0,001$ & $<0,001$ & $<0,001$ & $<0,001$ & $<0,001$ \\
\hline & & & & 02310 & $<0,001$ & $<0,001$ & $<0,001$ & $<0,001$ & $<0,001$ & $<0,001$ \\
\hline & & & & 02400 & $<0,001$ & $<0,001$ & $<0,001$ & $<0,001$ & $<0,001$ & $<0,001$ \\
\hline & & & & 02490 & $<0,001$ & $<0,001$ & $<0,001$ & $<0,001$ & $<0,001$ & $<0,001$ \\
\hline & & & & 02600 & $<0,001$ & $<0,001$ & $<0,001$ & $<0,001$ & $<0,001$ & $<0,001$ \\
\hline & & & & 02700 & $<0,001$ & $<0,001$ & $<0,001$ & $<0,001$ & $<0,001$ & $<0,001$ \\
\hline & & & & 02900 & $<0,001$ & $<0,001$ & $<0,001$ & $<0,001$ & $<0,001$ & $<0,001$ \\
\hline Ferro Total & $\mathrm{mg} / \mathrm{L}$ & & PARB & 02100 & 1,5 & 0,8 & 0,19 & 0,9 & 0,82 & 0,41 \\
\hline
\end{tabular}




\begin{tabular}{|c|c|c|c|c|c|c|c|c|c|c|}
\hline \multicolumn{11}{|c|}{ Resultados dos parâmetros e indicadores de qualidade das águas - CETESB } \\
\hline UGRHI: & \multicolumn{3}{|c|}{ PARAIBA DO SUL } & & & Classe : & \multicolumn{2}{|c|}{2} & \multirow[t]{2}{*}{ Ano: } & \multirow[t]{2}{*}{2003} \\
\hline$\ldots$ & & & & & & & & & & \\
\hline $\begin{array}{l}\text { Descrição do } \\
\text { parâmetro }\end{array}$ & Unidade & $\begin{array}{l}\text { Padrão } \\
\text { CONAMA }\end{array}$ & \multicolumn{2}{|c|}{ Posto de Monitoramento } & 19/2/2003 & 2/4/2003 & 25/6/2003 & 19/8/2003 & $15 / 10 / 2003$ & $10 / 12 / 2003$ \\
\hline & & 0,3 & & 02200 & 2,86 & 0,95 & 0,55 & 0,82 & 1,1 & 1,07 \\
\hline & & Fe dissolv. & & 02300 & 2,86 & 0,93 & 0,82 & 0,68 & 1,6 & 1,03 \\
\hline & & & & 02310 & 2,24 & 0,75 & 0,6 & 0,69 & 1,2 & 1,21 \\
\hline & & & & 02400 & 2,45 & 0,96 & 0,69 & 0,62 & 1,2 & 1,22 \\
\hline & & & & 02490 & 2,57 & 1,12 & 0,45 & 18 & 1,4 & 1,38 \\
\hline & & & & 02600 & 2,86 & 1,52 & 2,42 & 0,62 & 2,5 & 1,71 \\
\hline & & & & 02700 & 2,78 & 1,6 & 1,03 & 0,86 & 3,2 & 1,99 \\
\hline & & & & 02900 & 2,64 & 3,69 & 1,44 & 0,84 & 2,7 & 1,85 \\
\hline Fósforo & $\mathrm{mg} / \mathrm{L}$ & 0,025 & JAGI & 02900 & 0,02 & 0,02 & 0,05 & 0,06 & 0,06 & 0,11 \\
\hline \multirow[t]{9}{*}{ Total } & & 0,05 & \multirow[t]{9}{*}{ PARB } & 02100 & 0,01 & 0,01 & 0,01 & 0,02 & 0,01 & 0,04 \\
\hline & & & & 02200 & 0,09 & 0,03 & 0,03 & 0,04 & 0,03 & 0,08 \\
\hline & & & & 02300 & 0,05 & 0,07 & 0,02 & 0,04 & 0,02 & 0,1 \\
\hline & & & & 02310 & 0,04 & 0,06 & 0,04 & 0,04 & 0,02 & 0,08 \\
\hline & & & & 02400 & 0,05 & 0,06 & 0,04 & 0,06 & 0,04 & 0,06 \\
\hline & & & & 02490 & 0,06 & 0,09 & 0,03 & 0,05 & 0,08 & 0,13 \\
\hline & & & & 02600 & 0,1 & 0,09 & 0,01 & 0,08 & 0,12 & 0,12 \\
\hline & & & & 02700 & 0,07 & 0,07 & 0,03 & 0,01 & 0,02 & 0,1 \\
\hline & & & & 02900 & 0,05 & 0,06 & 0,08 & 0,04 & 0,11 & 0,1 \\
\hline & & & & & & & & & & \\
\hline \multirow[t]{8}{*}{ Manganês } & $\mathrm{mg} / \mathrm{L}$ & 0,1 & \multirow[t]{8}{*}{ PARB } & 02100 & 0,11 & 0,07 & 0,01 & 0,02 & 0,04 & 0,07 \\
\hline & & & & 02200 & 0,09 & 0,06 & 0,05 & 0,04 & 0,07 & 0,05 \\
\hline & & & & 02300 & 0,10 & 0,07 & 0,05 & 0,06 & 0,10 & 0,07 \\
\hline & & & & 02310 & 0,08 & 0,06 & 0,06 & 0,08 & 0,07 & 0,06 \\
\hline & & & & 02400 & 0,06 & 0,07 & 0,05 & 0,03 & 0,06 & 0,08 \\
\hline & & & & 02490 & 0,08 & 0,05 & 0,02 & 0,03 & 0,05 & 0,07 \\
\hline & & & & 02600 & 0,09 & 0,09 & 0,06 & 0,02 & 0,07 & 0,08 \\
\hline & & & & 02700 & 0,08 & 0,08 & 0,05 & 0,03 & 0,08 & 0,06 \\
\hline
\end{tabular}




\begin{tabular}{|c|c|c|c|c|c|c|c|c|c|c|}
\hline \multicolumn{11}{|c|}{ Resultados dos parâmetros e indicadores de qualidade das águas - CETESB } \\
\hline UGRHI: & \multicolumn{3}{|c|}{ PARAIBA DO SUL } & & & Classe : & \multicolumn{2}{|c|}{2} & \multirow{3}{*}{\begin{tabular}{|l|} 
Ano: \\
$15 / 10 / 2003$ \\
\end{tabular}} & \multirow{4}{*}{$\begin{array}{c}2003 \\
10 / 12 / 2003 \\
0,05\end{array}$} \\
\hline$\ldots$ & & & & & & & & & & \\
\hline $\begin{array}{l}\text { Descrição do } \\
\text { parâmetro }\end{array}$ & Unidade & $\begin{array}{l}\text { Padrão } \\
\text { CONAMA }\end{array}$ & \multicolumn{2}{|c|}{ Posto de Monitoramento } & 19/2/2003 & 2/4/2003 & 25/6/2003 & 19/8/2003 & & \\
\hline & & & & 02900 & 0,07 & 0,08 & 0,06 & 0,03 & 0,06 & \\
\hline \multirow{10}{*}{ Mercúrio } & $\overline{\mathrm{mg} / \mathrm{L}}$ & 0,0002 & JAGI & 02900 & 0,0001 & 0,0001 & 0,0002 & 0,0001 & 0,0001 & 0,0001 \\
\hline & & & \multirow{9}{*}{$\overline{\text { PARB }}$} & 02100 & 0,0001 & 0,0001 & 0,0002 & 0,0001 & 0,0001 & 0,0001 \\
\hline & & & & 02200 & 0,0001 & 0,0001 & 0,0002 & 0,0001 & 0,0001 & 0,0001 \\
\hline & & & & 02300 & 0,0001 & 0,0001 & 0,0001 & 0,0001 & 0,0001 & 0,0001 \\
\hline & & & & 02310 & 0,0001 & 0,0001 & 0,0001 & 0,0001 & 0,0001 & 0,0001 \\
\hline & & & & 02400 & 0,0001 & 0,0001 & 0,0001 & 0,0001 & 0,0001 & 0,0001 \\
\hline & & & & 02490 & 0,0001 & 0,0001 & 0,0001 & 0,0001 & 0,0001 & 0,0001 \\
\hline & & & & 02600 & 0,0001 & 0,0002 & 0,0001 & 0,0001 & 0,0001 & 0,0001 \\
\hline & & & & 02700 & 0,0001 & 0,0001 & 0,0001 & 0,0001 & 0,0001 & 0,0001 \\
\hline & & & & 02900 & 0,0001 & 0,0001 & 0,0001 & 0,0001 & 0,0001 & 0,0001 \\
\hline \multirow[t]{9}{*}{ N. Amoniacal } & $\mathrm{mg} / \mathrm{L}$ & 0,5 & \multirow[t]{9}{*}{ PARB } & 02100 & 0,03 & $<0,01$ & 0,03 & 0,08 & 0,06 & 0,04 \\
\hline & & $3,7(\mathrm{pH}<7,5)$ & & 02200 & 0,05 & 0,02 & 0,03 & 0,12 & 0,14 & 0,15 \\
\hline & & & & 02300 & 0,13 & 0,12 & 0,08 & 0,15 & 0,20 & 0,38 \\
\hline & & & & 02310 & 0,13 & 0,09 & 0,11 & 0,15 & 0,18 & 0,35 \\
\hline & & & & 02400 & 0,16 & 0,14 & 0,06 & 0,09 & 0,11 & 0,27 \\
\hline & & & & 02490 & 0,12 & 0,10 & 0,08 & 0,06 & 0,10 & 0,13 \\
\hline & & & & 02600 & 0,11 & 0,22 & 0,21 & 0,11 & 0,14 & 0,12 \\
\hline & & & & 02700 & 0,13 & 0,17 & 0,08 & 0,09 & 0,10 & 0,12 \\
\hline & & & & 02900 & 0,05 & 0,09 & 0,10 & 0,09 & 0,05 & 0,10 \\
\hline \multirow[t]{7}{*}{ N. Nitrato } & $\mathrm{mg} / \mathrm{L}$ & 10 & \multirow[t]{7}{*}{ PARB } & 02100 & 0,150 & 0,140 & 0,080 & 0,080 & 0,080 & 0,220 \\
\hline & & & & 02200 & 0,250 & 0,140 & 0,080 & 0,070 & 0,180 & 0,230 \\
\hline & & & & 02300 & 0,280 & 0,280 & 0,120 & 0,160 & 0,250 & 0,400 \\
\hline & & & & 02310 & 0,330 & 0,290 & 0,150 & 0,170 & 0,240 & 0,410 \\
\hline & & & & 02400 & 0,380 & 0,460 & 0,340 & 0,370 & 0,480 & 0,480 \\
\hline & & & & 02490 & 0,450 & 0,590 & 0,360 & 0,430 & 0,560 & 0,550 \\
\hline & & & & 02600 & 0,560 & 0,530 & 0,410 & 0,430 & 0,560 & 0,500 \\
\hline
\end{tabular}




\begin{tabular}{|c|c|c|c|c|c|c|c|c|c|c|}
\hline \multicolumn{11}{|c|}{ Resultados dos parâmetros e indicadores de qualidade das águas - CETESB } \\
\hline UGRHI: & \multicolumn{3}{|c|}{ PARAIBA DO SUL } & & & Classe: & \multicolumn{2}{|c|}{2} & \multirow{3}{*}{\begin{tabular}{|l|} 
Ano: \\
$15 / 10 / 2003$ \\
\end{tabular}} & \multirow{3}{*}{$\begin{array}{r}2003 \\
10 / 12 / 2003\end{array}$} \\
\hline & & & & & & & & & & \\
\hline $\begin{array}{l}\text { Descrição do } \\
\text { parâmetro }\end{array}$ & Unidade & $\begin{array}{l}\text { Padrão } \\
\text { CONAMA }\end{array}$ & \multicolumn{2}{|c|}{ Posto de Monitoramento } & $19 / 2 / 2003$ & 2/4/2003 & $25 / 6 / 2003$ & $19 / 8 / 2003$ & & \\
\hline & & & & 02700 & 0,610 & 0,540 & 0,440 & 0,500 & 0,620 & 0,530 \\
\hline & & & & 02900 & 0,680 & 0,400 & 0,520 & 0,610 & 0,700 & 0,470 \\
\hline \multirow[t]{9}{*}{ N. Nitrito } & $\mathrm{mg} / \mathrm{L}$ & $\overline{1}$ & \multirow[t]{9}{*}{ PARB } & 02100 & 0,004 & 0,001 & 0,001 & 0,006 & 0,001 & 0,050 \\
\hline & & & & 02200 & 0,010 & 0,004 & 0,001 & 0,014 & 0,010 & 0,040 \\
\hline & & & & 02300 & 0,013 & 0,012 & 0,004 & 0,019 & 0,018 & 0,046 \\
\hline & & & & 02310 & 0,016 & 0,010 & 0,005 & 0,026 & 0,018 & 0,035 \\
\hline & & & & 02400 & 0,019 & 0,012 & 0,008 & 0,016 & 0,021 & 0,037 \\
\hline & & & & 02490 & 0,014 & 0,012 & 0,006 & 0,006 & 0,021 & 0,024 \\
\hline & & & & 02600 & 0,014 & 0,012 & 0,008 & 0,014 & 0,023 & 0,018 \\
\hline & & & & 02700 & 0,015 & 0,016 & 0,005 & 0,016 & 0,021 & 0,024 \\
\hline & & & & 02900 & 0,012 & 0,016 & 0,005 & 0,014 & 0,013 & 0,011 \\
\hline \multirow[t]{9}{*}{ Míquel } & $\mathrm{mg} / \mathrm{L}$ & 0,025 & \multirow[t]{9}{*}{ PARB } & 02100 & $<0,02$ & $<0,02$ & $<0,008$ & $<0,008$ & $<0,008$ & $<0,008$ \\
\hline & & & & 02200 & $<0,02$ & $<0,02$ & $<0,008$ & $<0,004$ & $<0,008$ & $<0,008$ \\
\hline & & & & 02300 & $<0,02$ & $<0,02$ & $<0,008$ & $<0,004$ & $<0,008$ & $i<0,08$ \\
\hline & & & & 02310 & $<0,02$ & $<0,02$ & $<0,008$ & $<0,004$ & $<0,008$ & $<0,008$ \\
\hline & & & & 02400 & $<0,02$ & $<0,02$ & $<0,008$ & $<0,004$ & $<0,008$ & $<0,008$ \\
\hline & & & & 02490 & $<0,02$ & $<0,02$ & $<0,008$ & $<0,008$ & 0,008 & $<0,008$ \\
\hline & & & & 02600 & $<0,02$ & $<0,02$ & $<0,008$ & $<0,004$ & $<0,008$ & $<0,008$ \\
\hline & & & & 02700 & $<0,02$ & $<0,02$ & $<0,008$ & $<0,004$ & $<0,008$ & $<0,008$ \\
\hline & & & & 02900 & $<0,02$ & $<0,02$ & $<0,008$ & $<0,004$ & $<0,008$ & $<0,008$ \\
\hline \multirow[t]{7}{*}{ ANKT } & $\mathrm{mg} / \mathrm{L}$ & & JAGI & 02900 & 0,21 & 0,25 & 0,38 & 0,19 & 2,00 & 0,35 \\
\hline & & & \multirow[t]{6}{*}{ PARB } & 02100 & 0,31 & 0,19 & 0,25 & 0,14 & 0,44 & 0,12 \\
\hline & & & & 02200 & 0,05 & 0,51 & 0,46 & 0,37 & 0,21 & 0,64 \\
\hline & & & & 02300 & 0,19 & 0,33 & 0,31 & 0,33 & 0,44 & 0,63 \\
\hline & & & & 02310 & 0,22 & 0,33 & 0,31 & 0,35 & 0,42 & 0,58 \\
\hline & & & & 02400 & 0,17 & 0,46 & 0,44 & 0,51 & 0,44 & 0,55 \\
\hline & & & & 02490 & 0,19 & 0,49 & 0,38 & 0,21 & 0,35 & 0,49 \\
\hline
\end{tabular}




\begin{tabular}{|c|c|c|c|c|c|c|c|c|c|c|}
\hline \multicolumn{11}{|c|}{ Resultados dos parâmetros e indicadores de qualidade das águas - CETESB } \\
\hline UGRHI: & \multicolumn{3}{|c|}{ PARAIBA DO SUL } & & & Classe: & 2 & & \multirow{2}{*}{ Ano: } & \multirow[t]{2}{*}{2003} \\
\hline$\ldots$ & & & & & & & & & & \\
\hline \multirow[t]{4}{*}{$\begin{array}{c}\text { Descrição do } \\
\text { parâmetro }\end{array}$} & \multirow[t]{4}{*}{ Unidade } & \multirow[t]{2}{*}{$\begin{array}{l}\text { Padrão } \\
\text { CONAMA }\end{array}$} & \multicolumn{2}{|c|}{ Posto de Monitoramento } & \multirow{2}{*}{$\frac{19 / 2 / 2003}{0,30}$} & \multirow{2}{*}{$\frac{2 / 4 / 2003}{0,78}$} & 25/6/2003 & $19 / 8 / 2003$ & $15 / 10 / 2003$ & $10 / 12 / 2003$ \\
\hline & & & & 02600 & & & 0,56 & 0,39 & 0,55 & 0,40 \\
\hline & & & & 02700 & 0,33 & 0,40 & 0,31 & 0,29 & 0,51 & 0,37 \\
\hline & & & & 02900 & 0,12 & 0,29 & 0,36 & 0,29 & 0,48 & 0,35 \\
\hline \multirow{10}{*}{ OD } & & & \multirow{10}{*}{ PARB } & & & & & & & \\
\hline & $\mathrm{mg} / \mathrm{L}$ & 5 & & 02100 & 2,90 & 4,60 & 6,60 & 7,40 & 6,60 & 5,20 \\
\hline & & & & 02200 & 5,00 & 5,20 & 6,10 & 7,60 & 6,50 & 5,90 \\
\hline & & & & 02300 & 2,30 & 1,10 & 4,60 & 5,80 & 4,70 & 2,50 \\
\hline & & & & 02310 & 2,40 & 2,00 & 4,40 & 5,80 & 5,40 & 2,60 \\
\hline & & & & 02400 & 1,00 & 1,10 & 3,00 & 3,30 & 3,40 & 1,00 \\
\hline & & & & 02490 & 3,50 & 3,50 & 5,10 & 5,70 & 4,40 & 4,00 \\
\hline & & & & 02600 & 3,20 & 3,00 & 4,40 & 5,50 & 6,40 & 3,20 \\
\hline & & & & 02700 & 3,40 & 3,50 & 4,60 & 4,70 & 3,70 & 3,00 \\
\hline & & & & 02900 & 6,30 & 5,80 & 7,20 & 7,70 & 6,50 & 6,20 \\
\hline \multirow[t]{9}{*}{ Óleos e Graxas } & $\mathrm{mg} / \mathrm{L}$ & & \multirow[t]{9}{*}{ PARB } & 02100 & & & & & & \\
\hline & & & & 02200 & & & & & & \\
\hline & & & & 02300 & & & & & & \\
\hline & & & & 02310 & & & & & & \\
\hline & & & & 02400 & & & & & & \\
\hline & & & & 02490 & 9,000 & 2,000 & $<0,1$ & 1,000 & $<1$ & $<1$ \\
\hline & & & & 02600 & & & & & & \\
\hline & & & & 02700 & & & & & & \\
\hline & & & & 02900 & & & & & & \\
\hline \multirow[t]{5}{*}{ Pot. Form. THM } & $\mu g / L$ & & \multirow[t]{5}{*}{ PARB } & 02100 & & & & & & \\
\hline & & & & 02200 & 315,000 & & 289,000 & 167,000 & & 253,000 \\
\hline & & & & 02300 & & & & & & \\
\hline & & & & 02310 & 304,000 & & 204,000 & 224,000 & & 293,000 \\
\hline & & & & 02400 & & & & & & \\
\hline
\end{tabular}




\begin{tabular}{|c|c|c|c|c|c|c|c|c|c|c|}
\hline \multicolumn{11}{|c|}{ Resultados dos parâmetros e indicadores de qualidade das águas - CETESB } \\
\hline UGRHI: & \multicolumn{3}{|c|}{ PARAIBA DO SUL } & & & Classe : & \multicolumn{2}{|c|}{2} & \multirow[t]{2}{*}{ Ano: } & \multirow[t]{2}{*}{2003} \\
\hline . & & & & & & & & & & \\
\hline \multirow[t]{5}{*}{\begin{tabular}{|c|}
$\begin{array}{c}\text { Descrição do } \\
\text { parâmetro }\end{array}$ \\
\end{tabular}} & \multirow[t]{5}{*}{ Unidade } & \multirow[t]{5}{*}{$\begin{array}{l}\text { Padrão } \\
\text { CONAMA }\end{array}$} & \multicolumn{2}{|c|}{ Posto de Monitoramento } & \multirow{2}{*}{$\begin{array}{c}19 / 2 / 2003 \\
439,000\end{array}$} & \multirow[t]{2}{*}{ 2/4/2003 } & \multirow{2}{*}{$\begin{array}{c}25 / 6 / 2003 \\
342,000\end{array}$} & \multirow{2}{*}{$\begin{array}{c}19 / 8 / 2003 \\
185,000\end{array}$} & \multirow[t]{2}{*}{$15 / 10 / 2003$} & \multirow{2}{*}{$\begin{array}{c}10 / 12 / 2003 \\
608,000\end{array}$} \\
\hline & & & & 02490 & & & & & & \\
\hline & & & & 02600 & 302,000 & & 450,000 & 219,000 & & 583,000 \\
\hline & & & & 02700 & & & & & & \\
\hline & & & & 02900 & & & & & & \\
\hline \multirow[t]{10}{*}{ Res. Filtrável } & $\mathrm{mg} / \mathrm{L}$ & 500 & JAGI & 02900 & 47 & 99 & 81 & 26 & 42 & 30 \\
\hline & & & \multirow[t]{9}{*}{ PARB } & 02100 & 31 & 80 & 48 & 22 & 25 & 36 \\
\hline & & & & 02200 & 104 & 105 & 88 & 56 & 73 & 42 \\
\hline & & & & 02300 & 120 & 144 & 90 & 77 & 82 & 78 \\
\hline & & & & 02310 & 104 & 123 & 83 & 72 & 94 & 85 \\
\hline & & & & 02400 & 104 & 130 & 84 & 69 & 66 & 170 \\
\hline & & & & 02490 & 91 & 110 & 85 & 80 & 80 & 89 \\
\hline & & & & 02600 & 88 & 124 & 85 & 79 & 96 & 85 \\
\hline & & & & 02700 & 101 & 126 & 88 & 73 & 86 & 81 \\
\hline & & & & 02900 & 108 & 131 & 91 & 80 & 85 & 159 \\
\hline \multirow[t]{9}{*}{ Res. Total } & $\mathrm{mg} / \mathrm{L}$ & & \multirow[t]{9}{*}{ PARB } & 02100 & 42 & 85 & 55 & 24 & 31 & 46 \\
\hline & & & & 02200 & 133 & 117 & 100 & 63 & 81 & 78 \\
\hline & & & & 02300 & 147 & 154 & 107 & 83 & 98 & 98 \\
\hline & & & & 02310 & 125 & 130 & 93 & 79 & 98 & 108 \\
\hline & & & & 02400 & 130 & 135 & 95 & 76 & 82 & 189 \\
\hline & & & & 02490 & 121 & 116 & 90 & 83 & 92 & 106 \\
\hline & & & & 02600 & 122 & 131 & 129 & 87 & 136 & 112 \\
\hline & & & & 02700 & 129 & 138 & 98 & 80 & 124 & 115 \\
\hline & & & & 02900 & 134 & 179 & 109 & 88 & 125 & 185 \\
\hline \multirow[t]{3}{*}{ Res. Volátil } & $\mathrm{mg} / \mathrm{L}$ & & \multirow[t]{3}{*}{ PARB } & 02100 & 0 & 0 & 0 & 0 & 0 & 0 \\
\hline & & & & 02200 & 46 & 28 & 62 & 5 & 7 & 15 \\
\hline & & & & 02300 & 0 & 0 & 0 & 0 & 0 & 0 \\
\hline
\end{tabular}




\begin{tabular}{|c|c|c|c|c|c|c|c|c|c|c|}
\hline \multicolumn{11}{|c|}{ Resultados dos parâmetros e indicadores de qualidade das águas - CETESB } \\
\hline UGRHI: & \multicolumn{3}{|c|}{ PARAIBA DO SUL } & & & Classe: & \multicolumn{2}{|c|}{2} & \multirow{2}{*}{ 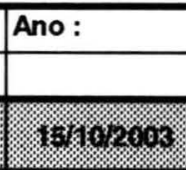 } & \multirow{2}{*}{ 2003 } \\
\hline \multirow[t]{7}{*}{ 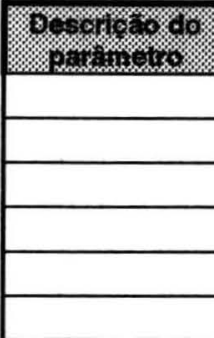 } & \multirow[t]{2}{*}{ 8. } & \multirow[t]{2}{*}{ (1) } & \multicolumn{2}{|c|}{ 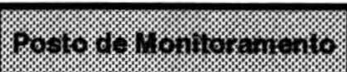 } & \multirow{2}{*}{$\frac{\sqrt{2}}{38}$} & \multirow{2}{*}{$\frac{18}{31}$} & \multirow{2}{*}{$\frac{\gamma^{4}}{54}$} & \multirow{2}{*}{$\frac{1968}{7}$} & & \\
\hline & & & & 02310 & & & & & 16 & 23 \\
\hline & & & & 02400 & 0 & 0 & 0 & 0 & 0 & 0 \\
\hline & & & & 02490 & 38 & 29 & 59 & 16 & 9 & 23 \\
\hline & & & & 02600 & 36 & 28 & 48 & 14 & 17 & 26 \\
\hline & & & & 02700 & 0 & 0 & 0 & 0 & 0 & 0 \\
\hline & & & & 02900 & 0 & 0 & 0 & 0 & 0 & 0 \\
\hline Surfactantes & $\mathrm{mg} / \mathrm{L}$ & 0,5 & PARB & 02100 & $<0,01$ & $<0,01$ & $<0,01$ & 0,040 & $<0,01$ & $<0,01$ \\
\hline & & & & 02200 & $<0,01$ & $<0,01$ & $<0,01$ & 0,040 & $<0,01$ & $<0,01$ \\
\hline & & & & 02300 & $<0,01$ & $<0,01$ & $<0,01$ & 0,050 & $<0,01$ & $<0,01$ \\
\hline & & & & 02310 & $<0,01$ & $<0,01$ & $<0,01$ & 0,040 & $<0,01$ & $<0,01$ \\
\hline & & & & 02400 & $<0,01$ & $<0,01$ & $<0,01$ & 0,040 & $<0,01$ & $<0,1$ \\
\hline & & & & 02490 & $<0,01$ & $<0,01$ & $<0,01$ & 0,030 & $<0,01$ & $<0,01$ \\
\hline & & & & 02600 & $<0,01$ & 0,060 & $<0,01$ & $<0,01$ & $<0,01$ & $<0,01$ \\
\hline & & & & 02700 & $<0,01$ & $<0,01$ & $<0,01$ & 0,060 & $<0,01$ & $<0,01$ \\
\hline & & & & 02900 & $<0,01$ & $<0,01$ & $<0,01$ & 0,040 & $<0,01$ & $<0,01$ \\
\hline Turbidez & UNT & 100 & PARB & 02100 & 30 & 15 & 5 & 6 & 8 & 8 \\
\hline & & & & 02200 & 54 & 18 & 12 & 9 & 11 & 19 \\
\hline & & & & 02300 & 57 & 19 & 26 & 11 & 28 & 19 \\
\hline & & & & 02310 & 47 & 16 & 22 & 14 & 20 & 26 \\
\hline & & & & 02400 & 54 & 13 & 22 & 13 & 19 & 17 \\
\hline & & & & 02490 & 40 & 13 & 11 & 8 & 24 & 23 \\
\hline & & & & 02600 & 39 & 19 & 62 & 13 & 61 & 32 \\
\hline & & & & 02700 & 36 & 24 & 16 & 15 & 63 & 34 \\
\hline & & & & 02900 & 34 & 78 & 27 & 16 & 71 & 28 \\
\hline Zinco & $\mathrm{mg} / \mathrm{L}$ & 0,18 & PARB & 02100 & 0,020 & 0,020 & $<0,008$ & 0,020 & 0,020 & 0,020 \\
\hline & & & & 02200 & 0,020 & 0,030 & 0,020 & $<0,004$ & 0,020 & $<0,008$ \\
\hline & & & & 02300 & 0,030 & 0,020 & $<0,008$ & $<0,004$ & 0,030 & 0,020 \\
\hline
\end{tabular}




\begin{tabular}{|c|c|c|c|c|c|c|c|c|c|c|}
\hline \multicolumn{11}{|c|}{ Resultados dos parâmetros e indicadores de qualidade das águas - CETESB } \\
\hline UGRHI: & \multicolumn{3}{|c|}{ PARAIBA DO SUL } & & & Classe : & \multicolumn{2}{|c|}{2} & \multirow[t]{2}{*}{ Ano: } & \multirow[t]{2}{*}{2003} \\
\hline$\cdots$ & & & & & & & & & & \\
\hline $\begin{array}{l}\text { Descrição do } \\
\text { parâmetro }\end{array}$ & Unidade & $\begin{array}{l}\text { Padrão } \\
\text { CONAMA }\end{array}$ & \multicolumn{2}{|c|}{ Posto de Monitoramento } & 19/2/2003 & 2/4/2003 & 25/6/2003 & $19 / 8 / 2003$ & $15 / 10 / 2003$ & 10/12/2003 \\
\hline & & & & 02310 & 0,020 & 0,020 & $<0,008$ & 0,020 & 0,020 & 0,020 \\
\hline & & & & 02400 & 0,030 & 0,030 & $<0,008$ & $<0,004$ & 0,020 & $<0,008$ \\
\hline & & & & 02490 & 0,030 & 0,020 & $<0,008$ & $<0,008$ & 0,020 & 0,020 \\
\hline & & & & 02600 & 0,020 & 0,020 & 0,010 & 0,005 & 0,030 & 0,020 \\
\hline & & & & 02700 & 0,020 & 0,020 & $<0,008$ & $<0,004$ & 0,030 & 0,030 \\
\hline & & & & 02900 & 0,020 & 0,020 & $<0,008$ & $<0,004$ & 0,030 & 0,020 \\
\hline Parâmetro: & \multicolumn{2}{|c|}{ Microbiológicos } & & & & & & & & \\
\hline \multirow[t]{10}{*}{ Coli Fecal } & NMP/100mL & 1000 & JAGI & 02900 & 13000 & 24000 & 8000 & 2300 & 11000 & 2300 \\
\hline & & & \multirow[t]{9}{*}{$\overline{\text { PARB }}$} & 02100 & 230 & 22 & 1300 & 50 & 130 & 230 \\
\hline & & & & 02200 & 5000 & 3000 & 5000 & 1700 & 4900 & 2300 \\
\hline & & & & 02300 & 2200 & 23000 & 11000 & 3000 & 2200 & 13000 \\
\hline & & & & 02310 & 30000 & 13000 & 8000 & 13000 & 17000 & 4900 \\
\hline & & & & 02400 & 8000 & 8000 & 8000 & 1700 & 4900 & 1300 \\
\hline & & & & 02490 & 13000 & 23000 & 8000 & 1300 & 1700 & 13000 \\
\hline & & & & 02600 & 50000 & 900000 & 13000 & 3000 & 22000 & 130000 \\
\hline & & & & 02700 & 3000 & 300000 & 8000 & 1300 & 33000 & 13000 \\
\hline & & & & 02900 & 5000 & 50000 & 5000 & 5000 & 4900 & 4900 \\
\hline \multirow[t]{3}{*}{ Obs.: } & \multicolumn{8}{|c|}{ - Dados em vermelho representam valores superiores ao limite máximo estabelecido pela legislação } & & \\
\hline & \multicolumn{8}{|c|}{ - Dados em azul representam valores inferiores ao limite de deteç̧ão da metodologia de análise } & & \\
\hline & \multicolumn{8}{|c|}{ - Dados em verde representam o novos limites alterados pela Resolução CONAMA 357/05. } & & \\
\hline
\end{tabular}


ANEXO 4 - VAZÕES CALCULADAS SEGUNDO MÉTODO DA REGIONALIZAÇÃO HIDROLÓGICA

\begin{tabular}{|c|c|c|c|c|c|c|c|c|c|c|}
\hline Jas. & $-\mathbf{N}^{\circ}$ & NOME DA BACIA & AREA & Margem & Área & P média & Qesp & Qmédia & Qmédia & $Q_{7,10}$ \\
\hline & CPTI & 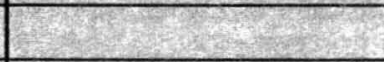 & $\left(\mathrm{Km}^{2}\right)$ & & acumul & plurianual & $\left(1 / \mathrm{s} . \mathrm{km}^{2}\right)$ & $(1 / s)$ & $\left(\mathrm{m}^{3} / \mathrm{s}\right)$ & $\left(\mathrm{m}^{3} / \mathrm{s}\right)$ \\
\hline & - & 40 & 1 & 1 & 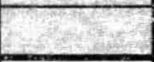 & $(\mathrm{mm})$ & 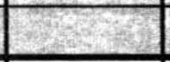 & D. & 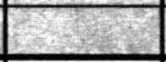 & 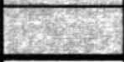 \\
\hline 1 & 2 & R. PARAITINGA & 2693,03 & D & & 1354,6 & 13,2 & 35547,7 & 35,55 & 11,82 \\
\hline 2 & 1 & R. PARAIBUNA & 1556,35 & E & & 1492,2 & 17,5 & 27289,5 & 27,29 & 9,07 \\
\hline 3 & & $\mathrm{~S} / \mathrm{N}$ & & D & & & & & & \\
\hline 4 & 3 & $\begin{array}{l}\text { C. CAMPO } \\
\text { REDONDO }\end{array}$ & 16,89 & $D$ & & 1250 & 9,9 & 167,3 & 0,17 & 0,06 \\
\hline 5 & 4 & C. DE BRAGANÇA & 39,67 & D & & 1250 & 9,9 & 392,9 & 0,39 & 0,13 \\
\hline 6 & 5 & R. DO SALTO & 111,07 & $E$ & & 1252,5 & 10,0 & 1108,9 & 1,11 & 0,37 \\
\hline 7 & & $\mathrm{~S} / \mathrm{N}$ & & E & & & & & & \\
\hline 8 & & $\begin{array}{l}\text { C. SANTO } \\
\text { ANTÔNIO }\end{array}$ & 2,85 & $\mathrm{E}$ & & 1150 & 6,8 & 19,3 & 0,02 & 0,01 \\
\hline 9 & & $\mathrm{~S} / \mathrm{N}$ & & D & & & & & & \\
\hline 10 & 7 & C. JATAÍ & 2,62 & $D$ & & 1150 & 6,8 & 17,7 & 0,02 & 0,01 \\
\hline 11 & & $\mathrm{~S} / \mathrm{N}$ & & D & & & & & & \\
\hline 2 & 8 & RIB. PANTANHÃO & 22,50 & D & & 1181,7 & 7,8 & 174,5 & 0,17 & 0,06 \\
\hline 13 & & $\mathrm{~S} / \mathrm{N}$ & & D & & & & & & \\
\hline 14 & 9 & R. CAPIVARI & 211,17 & $D$ & & 1232,6 & 9,4 & 1975,9 & 1,98 & 0,66 \\
\hline 15 & & $\mathrm{~S} / \mathrm{N}$ & & D & & & & & & \\
\hline 16 & 10 & R. VIRADOURO & 22,09 & D & & 1161,2 & 7,1 & 157,0 & 0,16 & 0,05 \\
\hline 17 & 11 & C. ITAMIRIM & 12,17 & D & & 1150 & 6,8 & 82,2 & 0,08 & 0,03 \\
\hline 18 & & $\mathrm{~S} / \mathrm{N}$ & & E & & & & & & \\
\hline \multirow[t]{2}{*}{19} & 12 & RIB. GUMEATINGA & 79,35 & $\mathrm{E}$ & & 1155,6 & 6,9 & 550,0 & 0,55 & 0,18 \\
\hline & & B S Branca & & & $4839,7 \mathrm{C}$ & & & & & \\
\hline 20 & & $\mathrm{~S} / \mathrm{N}$ & 2,25 & $E$ & 2,25 & & & & & \\
\hline 21 & & $\mathrm{~S} / \mathrm{N}$ & 1,92 & $D$ & 4,11 & & & & & \\
\hline
\end{tabular}




\begin{tabular}{|c|c|c|c|c|c|c|c|c|c|c|}
\hline 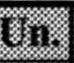 & r & MOMII D - B. & $4 \mathrm{me}, 1$. & 1218 & (1) & 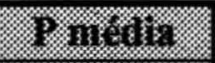 & (esis & 13. & 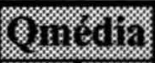 & 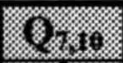 \\
\hline & (C.17) & & $(4)$ : & & 2801.12111 & 131. & $(18.6 .11 \%$ & (1) & $\left(80^{3} \cdot 5\right)$ & 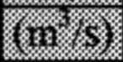 \\
\hline & & & & & & $(\min )$ & & & & \\
\hline & & Captação Sta Branca & & & 4,17 & & & & & \\
\hline 22 & 13 & C. DA ANGOLA & 3,75 & $E$ & 7,92 & 1150 & 6,8 & 25,3 & 0,03 & 0,01 \\
\hline 23 & 15 & RIB. SANTA FÉ & 19,5 & D & 27,42 & 1150 & 6,8 & 131,7 & 0,13 & 0,04 \\
\hline 24 & & $\mathrm{~S} / \mathrm{N}$ & 2,59 & D & 30,01 & & & & & \\
\hline & PARE & 02100/Flv. 58099000 & & & & & & & & \\
\hline 25 & & $\mathrm{~S} / \mathrm{N}$ & 0,27 & $\mathrm{E}$ & 30,28 & & & & & \\
\hline 26 & 14 & C. DO TABUÃO & 13,92 & $\mathrm{E}$ & 44,20 & 1150 & 6,8 & 94,0 & 0,09 & 0,03 \\
\hline 27 & & $\mathrm{~S} / \mathrm{N}$ & 5,6 & D & 49,80 & & & & & \\
\hline 28 & 16 & $\begin{array}{l}\text { C. FAZ. } \\
\text { HARMONIA }\end{array}$ & 4,4 & D & 54,20 & 1150 & 6,8 & 29,7 & 0,03 & 0,01 \\
\hline 29 & & $\mathrm{~S} / \mathrm{N}$ & 8,82 & $\mathrm{E}$ & 63,02 & & & & & \\
\hline 30 & 17 & RIB. DOS MONOS & 87,35 & E & 150,37 & 1158 & 7,0 & 612,1 & 0,61 & 0,20 \\
\hline 31 & & $\mathrm{~S} / \mathrm{N}$ & 0,3 & $\mathrm{E}$ & 150,67 & & & & & \\
\hline 32 & 19 & $\begin{array}{l}\text { C. VALE DA } \\
\text { ALEGRIA }\end{array}$ & 1,22 & $\mathrm{E}$ & 151,89 & 1150 & 6,8 & 8,2 & 0,01 & 0,00 \\
\hline 33 & & $\mathrm{~S} / \mathrm{N}^{*}$ & 4,17 & D & 156,06 & & & & & \\
\hline 34 & 18 & $\begin{array}{l}\text { C. CAMPO } \\
\text { GRANDE }\end{array}$ & 4 & D & 160,06 & 1150 & 6,8 & 27,0 & 0,03 & 0,01 \\
\hline 35 & & $\mathrm{~S} / \mathrm{N}$ & 2,52 & D & 162,58 & & & & & \\
\hline 36 & 20 & C. FAZ. DO MOTA & 1,92 & D & 164,50 & 1150 & 6,8 & 13,0 & 0,01 & 0,00 \\
\hline 37 & 21 & C. FAZ. CAIÇARA & 2,87 & $\mathrm{D}$ & 167,37 & 1150 & 6,8 & 19,4 & 0,02 & 0,01 \\
\hline 38 & & $\mathrm{~S} / \mathrm{N}$ & 9,03 & E & 176,40 & & & & & \\
\hline 39 & 22 & RIB. PUTIM & 83,70 & $\mathrm{E}$ & 260,10 & 1194 & 8,1 & 681,4 & 0,68 & 0,23 \\
\hline \multirow[t]{3}{*}{40} & & $\mathrm{~S} / \mathrm{N}$ & 12,84 & $\mathrm{E}$ & 272,94 & & & & & \\
\hline & & OcFibras & & & 272,94 & & & & & \\
\hline & & SABESP entre as & & & 272,94 & & & & & \\
\hline
\end{tabular}




\begin{tabular}{|c|c|c|c|c|c|c|c|c|c|c|}
\hline Vin & m & 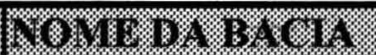 & (1) & 1, 6 . & (6.r. ca) & 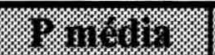 & 0.698 & 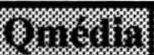 & 8nom & 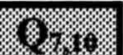 \\
\hline & (19111 & & 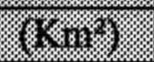 & & (201:1814 & 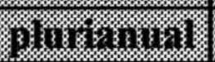 & $(18.61,4)$ & (1) / & $(17 \%$ & (17) \\
\hline & & & & & & (1) & & 8: & & \\
\hline & & pontes & & & & & & & & \\
\hline 41 & 23 & RIB. GUARAREMA & 73,42 & $E$ & 346,36 & 1189,8 & 8,0 & 588,0 & 0,59 & 0,20 \\
\hline 42 & 24 & $\begin{array}{l}\text { R. } \\
\text { COMPRIDO/ESTIV } \\
\text { A/IPIRANGA }\end{array}$ & 15,4 & $\mathrm{E}$ & 361,76 & 1157,7 & 7,0 & 107,8 & 0,11 & 0,04 \\
\hline 43 & & $\mathrm{~S} / \mathrm{N}$ & 1,96 & $\mathrm{E}$ & 363,72 & & & & & \\
\hline 44 & 25 & RIB. ITAPETI & 57,97 & $E$ & 421,69 & 1247,6 & 9,8 & 569,8 & 0,57 & 0,19 \\
\hline 45 & & $\mathrm{~S} / \mathrm{N}$ & 11,55 & $E$ & 433,24 & & & & & \\
\hline 46 & 27 & $\begin{array}{l}\text { RIB. SÃO } \\
\text { SEBASTIÃO }\end{array}$ & 19,55 & $E$ & 452,79 & 1250 & 9,9 & 193,6 & 0,19 & 0,06 \\
\hline 47 & & $\mathrm{~S} / \mathrm{N}$ & 7,74 & E & 460,53 & & & & & \\
\hline & & D S Silvestre (pte) & & & 460,53 & & & & & \\
\hline 18 & 28 & C. DO BAIRRINHO & 8,3 & E & 468,83 & 1250 & 9,9 & 82,2 & 0,08 & 0,03 \\
\hline & & C Faz Três Moleques & & $\mathrm{E}$ & 468,83 & & & & & \\
\hline 49 & & $\mathrm{~S} / \mathrm{N}$ & 28,13 & D & 496,96 & & & & & \\
\hline 50 & 26 & C. DE BOM JESUS & 2,35 & D & 499,31 & 1150 & 6,8 & 15,9 & 0,02 & 0,01 \\
\hline 51 & & $\mathrm{~S} / \mathrm{N}^{*}$ & 10,27 & D & 509,58 & & & & & \\
\hline 52 & 29 & C. 4 RIBEIRAS & 13,8 & D & 523,38 & 1181,9 & 7,8 & 107,1 & 0,11 & 0,04 \\
\hline 53 & & $\mathrm{~S} / \mathrm{N}$ & 20,14 & E & 543,52 & & & & & \\
\hline & & Est Porto Velho & & & 543,52 & & & & & \\
\hline & $\begin{array}{l}\text { SAAF } \\
58110 \\
\end{array}$ & $\begin{array}{l}\text { PARB02200/Flv. } \\
002\end{array}$ & & & 543,52 & 5383,24 & 140,1 & 0,0 & 0,00 & 0,00 \\
\hline 54 & & $\mathrm{~S} / \mathrm{N}$ & 2,55 & D & 546,07 & & & & & \\
\hline & & Pte N S Conceição & & & 546,07 & & & & & \\
\hline & & Pte N S Rosário & & $\mathrm{E}$ & 546,07 & & & & & \\
\hline 55 & 30 & RIB. DA COLÔNIA & 13,25 & D & 559,32 & 1218 & 8,9 & 117,9 & 0,12 & 0,04 \\
\hline
\end{tabular}




\begin{tabular}{|c|c|c|c|c|c|c|c|c|c|c|}
\hline 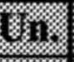 & N. & $10 \mathrm{MT} 10 . \mathrm{B} 4 \mathrm{Cr}$ & $4 \mathrm{mot}$, & Mangen: & $\sqrt{15}+2$ & ? 132619 & Cesp & (8) mentin & (6) 10.45 & (8): $:$. \\
\hline & (1) & & $(4)$ & & 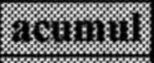 & 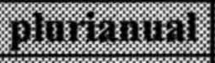 & $\left(8, x_{1}\right)$ & $(1,8)$ & 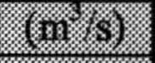 & $(m)$ \\
\hline & & & & & & (1.1.10) & & & & \\
\hline & & (Rhodia) & & & & & & & & \\
\hline & & jusante Rib. Colônia & & & 559,32 & & & & & \\
\hline 56 & 139 & $\begin{array}{l}\text { COMPL. HIDROL. } \\
\text { (vulgo Tanquinho) }\end{array}$ & 32,04 & $E$ & 591,36 & 1250 & 9,9 & 317,4 & 0,32 & 0,11 \\
\hline & & Kaiser & & E & 591,36 & & & & & \\
\hline & & $\begin{array}{l}\text { Chác. Rurais Sta } \\
\text { Maria }\end{array}$ & & D & 591,36 & & & & & \\
\hline & & $\begin{array}{l}\text { White } \\
\text { Martins/Cebrace }\end{array}$ & & & 591,36 & & & & & \\
\hline 57 & 138 & $\begin{array}{l}\text { S/N (C. } \\
\text { Sêco)/MNSConc e } \\
\text { Tec NSPenha } \\
\end{array}$ & 9,25 & D & 600,61 & 1250 & 9,9 & 91,6 & 0,09 & 0,03 \\
\hline & & Colap & & D & 600,61 & & & & & \\
\hline & & Pte via Dutra/Zeneca & & & 600,61 & & & & & \\
\hline & & Lanobrasil & & $\mathrm{D}$ & 600,61 & & & & & \\
\hline & & Henkel & & D & 600,61 & & & & & \\
\hline & & Pq Meia Lua & & D & 600,61 & & & & & \\
\hline & & Monsanto & & & 600,61 & & & & & \\
\hline 58 & 31 & $\begin{array}{l}\text { R. } \\
\text { COMPRIDO/Philips }\end{array}$ & 52,54 & $\mathrm{D}$ & 653,15 & 1244,2 & 9,7 & 510,8 & 0,51 & 0,17 \\
\hline 59 & 32 & $\begin{array}{l}\text { C. } \\
\text { LIMOEIRO/SidPains/ } \\
\text { Kodak/Johnson/Panas } \\
\text { onic }\end{array}$ & 14,75 & $\mathrm{D}$ & 667,90 & 1297,8 & 11,4 & 168,3 & 0,17 & 0,06 \\
\hline 60 & & $\mathrm{~S} / \mathrm{N}$ & 10,59 & $E$ & 678,49 & & & & & \\
\hline & \multicolumn{2}{|c|}{ PARB 02300} & & & 678,49 & & & & & \\
\hline $61 \mid$ & 50 & RIB. VERMELHO & 4,80 & $\mathrm{E}$ & 683,29 & 1350 & 13,1 & 62,7 & 0,06 & 0,02 \\
\hline
\end{tabular}




\begin{tabular}{|c|c|c|c|c|c|c|c|c|c|c|}
\hline (1i:8 & \%: & 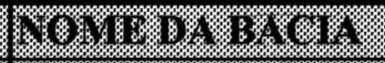 & 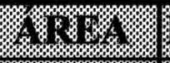 & 1816 & (1) & 1. 14 & (8) & \%1, & \%1 & 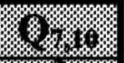 \\
\hline & (1) & & (4) & & 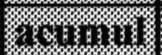 & 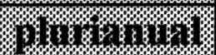 & 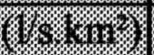 & / / / & (1) & $(1018)$ \\
\hline & & & & & & 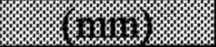 & & & & \\
\hline & Capta & ç̃̃o SJC/PARB 02310 & & D & 683,29 & & & & & \\
\hline 62 & 33 & RIB. DO VIDOCA & 43,60 & $\mathrm{D}$ & 726,89 & 1260,5 & 10,2 & 446,3 & 0,45 & 0,15 \\
\hline 63 & & $\mathrm{~S} / \mathrm{N}$ & & $\mathrm{E}$ & 726,89 & & & & & \\
\hline & & $\begin{array}{l}\text { R. JAGUARI (1300 } \\
\left.\mathrm{km}^{2}\right)\end{array}$ & & & & & & & & \\
\hline 64 & 56 & \begin{tabular}{|l|} 
RIB. JAGUARI \\
$1730,49 \mathrm{Km}^{2}$
\end{tabular} & 430,49 & $\mathrm{E}$ & 1157,38 & 1475,4 & 17,0 & 7320,5 & 7,32 & 2,43 \\
\hline 65 & & $\mathrm{~S} / \mathrm{N}$ & & $\mathrm{E}$ & 1157,38 & & & & & \\
\hline 66 & 60 & $\begin{array}{l}\text { R. } \\
\text { BUQUIRA/FERRÃO }\end{array}$ & 413,29 & $\mathrm{E}$ & 1570,67 & 1679,4 & 23,4 & 9683,8 & 9,68 & 3,22 \\
\hline 67 & 34 & RIB. LAVAPÉS & 14,55 & D & 1585,22 & 1323,3 & 12,2 & 177,7 & 0,18 & 0,06 \\
\hline 68 & 35 & RIB. PUTINS & 44,50 & $\mathrm{D}$ & 1629,72 & 1246 & 9,8 & 435,2 & 0,44 & 0,14 \\
\hline 69 & 36 & $\begin{array}{l}\text { COMPLEXO } \\
\text { HIDROL. }\end{array}$ & 12,25 & $\mathrm{D}$ & 1641,97 & 1350 & 13,1 & 159,9 & 0,16 & 0,05 \\
\hline 70 & & $\mathrm{~S} / \mathrm{N}$ & & E & 1641,97 & & & & & \\
\hline 71 & 64 & RIB. BUERAREMA & 8,92 & $\mathrm{E}$ & 1650,89 & 1399,1 & 14,6 & 130,2 & 0,13 & 0,04 \\
\hline 72 & 37 & R. ALAMBARI & 31,87 & D & 1682,76 & 1287,8 & 11,1 & 353,6 & 0,35 & 0,12 \\
\hline 73 & 66 & $\begin{array}{l}\text { C. FAZ. MONTE } \\
\text { ALEGRE }\end{array}$ & 9,05 & $\mathrm{E}$ & 1691,81 & 1430,1 & 15,6 & 141,0 & 0,14 & 0,05 \\
\hline 74 & & $\mathrm{~S} / \mathrm{N}$ & & $\mathrm{D}$ & 1691,81 & & & & & \\
\hline 75 & 38 & C. DOS VEADOS & 10,17 & $\mathrm{D}$ & 1701,98 & 1350 & 13,1 & 132,8 & 0,13 & 0,04 \\
\hline 76 & & $\mathrm{~S} / \mathrm{N}$ & & $E$ & 1701,98 & & & & & \\
\hline 77 & 68 & $\begin{array}{l}\text { RIB. } \\
\text { CASCUDO/BUTA }\end{array}$ & 31,32 & $\mathrm{E}$ & 1733,30 & 1469,7 & 16,8 & 527,0 & 0,53 & 0,18 \\
\hline 78 & & $\mathrm{~S} / \mathrm{N}$ & & $\mathrm{D}$ & 1733,30 & & & & & \\
\hline 79 & 39 & R. PARARANGABA & 71,57 & $\mathrm{D}$ & 1804,87 & 1283,4 & 11,0 & 784,2 & 0,78 & 0,26 \\
\hline
\end{tabular}




\begin{tabular}{|c|c|c|c|c|c|c|c|c|c|c|}
\hline 4. & ro & 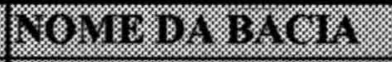 & $\sqrt{\mathrm{mog}}$ & 1) & inea & 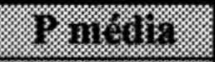 & 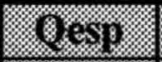 & sinesting & (6ningin & 6 \\
\hline & $(21011$ & & $(2,1)$ & & 1001.1111 & 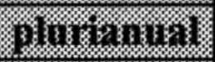 & $(16.817)$. & $(1.1)$ & $(n \pi)$ & $(117)$ \\
\hline & & & & & & (1) & & & & \\
\hline 80 & 40 & RIB. DA DIVISA & 61,57 & D & 1866,44 & 1272 & 10,6 & 652,5 & 0,65 & 0,22 \\
\hline 81 & & $\mathrm{~S} / \mathrm{N}$ & & D & 1866,44 & & & & & \\
\hline 82 & 41 & C. DOS LEÕES & 5,37 & D & 1871,81 & 1338,4 & 12,7 & 68,1 & 0,07 & 0,02 \\
\hline 83 & & $\mathrm{~S} / \mathrm{N}$ & & D & 1871,81 & & & & & \\
\hline 84 & 70 & RIB. CABUÇU & 46,19 & $\mathrm{E}$ & 1918,00 & 1425,1 & 15,4 & 712,3 & 0,71 & 0,24 \\
\hline 85 & & $\mathrm{~S} / \mathrm{N}$ & & E & 1918,00 & & & & & \\
\hline 86 & 42 & RIB. MANOEL LITO & 16,02 & D & 1934,02 & 1312,1 & 11,9 & 190,0 & 0,19 & 0,06 \\
\hline 87 & 73 & RIB. IRIGUAÇU & 38,85 & $\mathrm{E}$ & 1972,87 & 1469,3 & 16,8 & 653,2 & 0,65 & 0,22 \\
\hline & PARB & 302400 & & & & & & & & \\
\hline 88 & 43 & RIB. DOS MUDOS & 46,16 & D & 2019,03 & 1264,9 & 10,4 & 478,9 & 0,48 & 0,16 \\
\hline 89 & & $\mathrm{~S} / \mathrm{N}$ & & D & 2019,03 & & & & & \\
\hline 90 & 44 & $\begin{array}{l}\text { C. } \\
\text { GUAICARA/CAETA } \\
\text { NO }\end{array}$ & 27,21 & $\mathrm{D}$ & 2046,24 & 1265,6 & 10,4 & 282,9 & 0,28 & 0,09 \\
\hline 91 & & $\mathrm{~S} / \mathrm{N}$ & & $\mathrm{E}$ & 2046,24 & & & & & \\
\hline 92 & 76 & RIB. TAPERUCCU & 20,82 & $\mathrm{E}$ & 2067,06 & 1481,9 & 17,2 & 358,3 & 0,36 & 0,12 \\
\hline 93 & 45 & $\begin{array}{l}\text { RIB. CAÇAPAVA } \\
\text { VELHA }\end{array}$ & 30,85 & D & 2097,91 & 1275,6 & 10,7 & 330,4 & 0,33 & 0,11 \\
\hline 94 & & $\mathrm{~S} / \mathrm{N}$ & & $E$ & 2097,91 & & & & & \\
\hline 95 & 78 & $\begin{array}{l}\text { RIB. DAS } \\
\text { PITANGUEIRAS II }\end{array}$ & 22,32 & $\mathrm{E}$ & 2120,23 & 1487,3 & 17,4 & 387,9 & 0,39 & 0,13 \\
\hline 96 & & $\mathrm{~S} / \mathrm{N}$ & & $\mathrm{E}$ & 2120,23 & & & & & \\
\hline 97 & 46 & C. DA PONTE ALTA & 11,27 & D & 2131,50 & 1336,8 & 12,6 & 142,4 & 0,14 & 0,05 \\
\hline 98 & 80 & C. COMPRIDO & 11,15 & $\mathrm{E}$ & 2142,65 & 1442,8 & 16,0 & 178,2 & 0,18 & 0,06 \\
\hline 99 & 47 & RIB. PIRACANGUA & 47,19 & $\mathrm{D}$ & 2189,84 & 1281,2 & 10,9 & 513,8 & 0,51 & 0,17 \\
\hline 100 & 82 & RIB. DOSMOTAS & 22,14 & $E$ & 2211,98 & 1517,2 & 18,3 & 405,6 & 0,41 & 0,13 \\
\hline
\end{tabular}




\begin{tabular}{|c|c|c|c|c|c|c|c|c|c|c|}
\hline 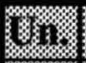 & \% & 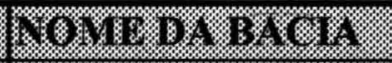 & STror & $48 \times 18$ & isma & 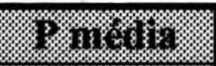 & (xesp: & (s) & (611068 & 8.1. \\
\hline & 1811 & & $(4)$ & & 201,18114 & 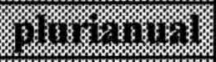 & 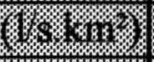 & 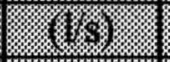 & 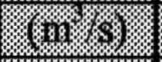 & $(1+18)$ \\
\hline & & & & & & 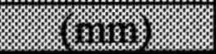 & & & & \\
\hline 101 & 48 & RIB. DO PINHÃO & 21,25 & D & 2233,23 & 1312,7 & 11,9 & 252,5 & 0,25 & 0,08 \\
\hline 102 & 49 & JUDEU & 17,17 & D & 2250,40 & 1348 & 13,0 & 223,1 & 0,22 & 0,07 \\
\hline \multirow[t]{2}{*}{103} & & $\mathrm{~S} / \mathrm{N}$ & & $\mathrm{E}$ & 2250,40 & & & & & \\
\hline & PARE & 302490 & & & & & & & & \\
\hline 104 & 51 & $\begin{array}{l}\text { RIB. DO MOINHO I } \\
\text { - STA CRUZ }\end{array}$ & 9,50 & D & 2259,90 & 1333,1 & 12,5 & 119,0 & 0,12 & 0,04 \\
\hline 105 & 52 & $\begin{array}{l}\text { RIB. DO MOINHO II } \\
\text { - CONVENTO } \\
\text { VELHO }\end{array}$ & 33,40 & D & 2293,30 & 1291,4 & 11,2 & 374,4 & 0,37 & 0,12 \\
\hline 106 & 85 & $\begin{array}{l}\text { RIB. DA } \\
\text { SERRAGEM }\end{array}$ & 54,40 & $\mathrm{E}$ & 2347,70 & 1544,7 & 19,2 & 1043,8 & 1,04 & 0,35 \\
\hline 107 & 87 & R. PIRACUAMA & 156,09 & $E$ & 2503,79 & 1712,5 & 24,5 & 3820,1 & 3,82 & 1,27 \\
\hline 108 & 53 & RIO UNA & 467,22 & D & 2971,01 & 1257,6 & 10,1 & 4739,7 & 4,74 & 1,58 \\
\hline 109 & & $\mathrm{~S} / \mathrm{N}$ & & D & 2971,01 & & & & & \\
\hline 110 & & $\mathrm{~S} / \mathrm{N}$ & & E & 2971,01 & & & & & \\
\hline 111 & 88 & $\begin{array}{l}\text { RIB. } \\
\text { DASPEDRAS/MAN } \\
\text { DU }\end{array}$ & 14,12 & $\mathrm{E}$ & 2985,13 & 1571,6 & 20,0 & 282,9 & 0,28 & 0,09 \\
\hline 112 & & $\mathrm{~S} / \mathrm{N}$ & & $E$ & 2985,13 & & & & & \\
\hline \multicolumn{11}{|c|}{ Fkr. 35183000} \\
\hline 113 & 54 & $\begin{array}{l}\text { R. DA } \\
\text { GALEGA/ANHANG } \\
\text { UERA }\end{array}$ & 18,92 & D & 3004,05 & 1335,6 & 12,6 & 238,4 & 0,24 & 0,08 \\
\hline 114 & 55 & R. DO CORTUME & 81,57 & $\mathrm{D}$ & 3085,62 & 1262 & 10,3 & 838,8 & 0,84 & 0,28 \\
\hline 115 & 57 & RIB. IPIRANGA & 53,80 & D & 3139,42 & 1297,8 & 11,4 & 613,9 & 0,61 & 0,20 \\
\hline 116 & 90 & RIB. DA PONTE & 40,85 & $\mathrm{E}$ & 3180,27 & 1601,7 & 21,0 & 857,2 & 0,86 & 0,29 \\
\hline
\end{tabular}




\begin{tabular}{|c|c|c|c|c|c|c|c|c|c|c|}
\hline 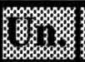 & \%. & 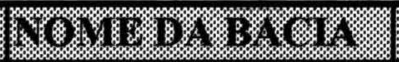 & Mror & $142.12=13$ & (1) & 9 inetis & $(8,83)$ & Crinesting & Mrivaria & (3.: \\
\hline & (17TII & & 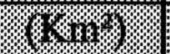 & & (r. con:10 & $91.40 .1,1,1$ & 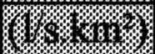 & (1/.) & $(\mathrm{n} / \mathrm{r} / \mathrm{r})$ & $(10.8)$ \\
\hline & (:) & & & & & : (1) & & & H & \\
\hline & & ALTA & & & & & & & & \\
\hline 117 & 58 & RIB. CAPITUBA & 41,57 & D & 3221,84 & 1274,6 & 10,7 & 444,0 & 0,44 & 0,15 \\
\hline 118 & & $\mathrm{~S} / \mathrm{N}$ & & D & 3221,84 & & & & & \\
\hline 119 & 59 & $\begin{array}{l}\text { RIB. } \\
\text { PIRATINI/SURDOS }\end{array}$ & 21,16 & $\mathrm{D}$ & 3243,00 & 1277,6 & 10,8 & 228,0 & 0,23 & 0,08 \\
\hline 120 & & $\mathrm{~S} / \mathrm{N}$ & & $\mathrm{D}$ & 3243,00 & & & & & \\
\hline 121 & 92 & \begin{tabular}{|l|} 
RIB. \\
TETEQUERA/GRAN \\
DE
\end{tabular} & 131,92 & $\mathrm{E}$ & 3374,92 & 1691,6 & 23,8 & 3141,7 & 3,14 & 1,04 \\
\hline 122 & & $\mathrm{~S} / \mathrm{N}$ & & $\mathrm{E}$ & 3374,92 & & & & & \\
\hline 123 & 93 & C. DO ROSÁRIO & 1,74 & E & 3376,66 & 1350 & 13,1 & 22,7 & 0,02 & 0,01 \\
\hline 124 & 61 & R. PIRAPITINGUI & 116,61 & $\mathrm{D}$ & 3493,27 & 1268,6 & 10,5 & 1223,3 & 1,22 & 0,41 \\
\hline 125 & & $\mathrm{~S} / \mathrm{N}$ & & $\mathrm{E}$ & 3493,27 & & & & & \\
\hline 126 & 95 & RIB. DOS BUENOS & 82,39 & $\mathrm{E}$ & 3575,66 & 1594,9 & 20,8 & 1711,2 & 1,71 & 0,57 \\
\hline 127 & 62 & RIB. ITAGUAÇU & 10,57 & D & 3586,23 & 1291,3 & 11,2 & 118,4 & 0,12 & 0,04 \\
\hline 128 & & $\mathrm{~S} / \mathrm{N}$ & & $\mathrm{E}$ & 3586,23 & & & & & \\
\hline & PARB & 02600 & & & & & & & & \\
\hline 129 & 96 & C. DO PUTIM & 25,10 & $\mathrm{E}$ & 3611,33 & 1440,5 & 15,9 & 399,2 & 0,40 & 0,13 \\
\hline 130 & & $\mathrm{~S} / \mathrm{N}$ & & $\mathrm{D}$ & 3611,33 & & & & & \\
\hline 131 & 63. & RIB. DA CHÁCARA & 5,67 & D & 3617,00 & 1319,2 & 12,1 & 68,5 & 0,07 & 0,02 \\
\hline 132 & 98 & $\begin{array}{l}\text { RIB. ÁGUA DOS } \\
\text { NEVES }\end{array}$ & 8,62 & $\mathrm{E}$ & 3625,62 & 1399,2 & 14,6 & 125,9 & 0,13 & 0,04 \\
\hline 133 & & $\mathrm{~S} / \mathrm{N}$ & & $E$ & 3625,62 & & & & & \\
\hline 134 & 99 & $\begin{array}{l}\text { RIB. } \\
\text { GUARATINGUETÁ }\end{array}$ & 159,17 & $\mathrm{E}$ & 3784,79 & 1630,2 & 21,9 & 3482,8 & 3,48 & 1,16 \\
\hline 135 & & $\mathrm{~S} / \mathrm{N}$ & & D & 3784,79 & & & & & \\
\hline
\end{tabular}




\begin{tabular}{|c|c|c|c|c|c|c|c|c|c|c|}
\hline 1) & r. & 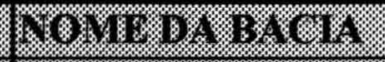 & She & 151.2. & 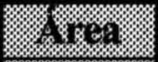 & Fing & (6) & 6romenten & 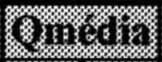 & $8,1: 2$ \\
\hline & (1) & & $(4,113)$ & & 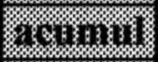 & 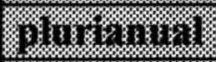 & 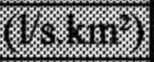 & (18) & $(1018)$ & $(101 \%$ \\
\hline & & & & & & 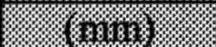 & & & & \\
\hline 136 & 65 & RIB. DOS MOTAS & 98,04 & D & 3882,83 & 1271,9 & 10,6 & 1038,7 & 1,04 & 0,35 \\
\hline 137 & 67 & $\begin{array}{l}\text { RIB. SÃO } \\
\text { GONÇALO }\end{array}$ & 114,75 & D & 3997,58 & 1359,2 & 13,3 & 1531,3 & 1,53 & 0,51 \\
\hline & Ely 58 & $2204000(2002)$ & & & & & & & & \\
\hline 138 & & $\mathrm{~S} / \mathrm{N}$ & & D & 3997,58 & & & & & \\
\hline 139 & 69 & RIB. SANTA RITA & 14,72 & $\mathrm{D}$ & 4012,30 & 1350 & 13,1 & 192,2 & 0,19 & 0,06 \\
\hline 140 & & $\mathrm{~S} / \mathrm{N}$ & & D & 4012,30 & & & & & \\
\hline 141 & & $\mathrm{~S} / \mathrm{N}$ & & $E$ & 4012,30 & & & & & \\
\hline 142 & 102 & RIB. PIAGUI & 171,37 & $\mathrm{E}$ & 4183,67 & 1766,3 & 26,2 & 4484,5 & 4,48 & 1,49 \\
\hline 143 & 71 & RIB. SÃO JOÃO & 6,00 & D & 4189,67 & 1373,9 & 13,8 & 82,8 & 0,08 & 0,03 \\
\hline 144 & 72 & $\begin{array}{l}\text { RIB. } \\
\text { FARROUPILHA }\end{array}$ & 15,72 & $D$ & 4205,39 & 1367 & 13,6 & 213,6 & 0,21 & 0,07 \\
\hline 145 & & $\mathrm{~S} / \mathrm{N}$ & & D & 4205,39 & & & & & \\
\hline 146 & 74 & RIB. TABUÃO & 77,95 & $\mathrm{D}$ & 4283,34 & 1400,8 & 14,7 & 1142,4 & 1,14 & 0,38 \\
\hline 147 & & $\mathrm{~S} / \mathrm{N}$ & & $\mathrm{D}$ & 4283,34 & & & & & \\
\hline 148 & & $\mathrm{~S} / \mathrm{N}$ & & $\mathrm{E}$ & 4283,34 & & & & & \\
\hline & PARE & 302700 & & & & & & & & \\
\hline 149 & 105 & $\begin{array}{l}\text { R. DAS } \\
\text { POSSES/MACACOS }\end{array}$ & 38,09 & $\mathrm{E}$ & 4321,43 & 1668,4 & 23,1 & 879,3 & 0,88 & 0,29 \\
\hline 150 & 107 & RIB. DA LIMEIRA & 62,07 & E & 4383,50 & 1624,3 & 21,7 & 1346,6 & 1,35 & 0,45 \\
\hline 151 & 75 & C. DOS PASSOS & 15,40 & $\mathrm{D}$ & 4398,90 & 1380,8 & 14,0 & 216,0 & 0,22 & 0,07 \\
\hline 152 & & $\mathrm{~S} / \mathrm{N}$ & & $\mathrm{E}$ & 4398,90 & & & & & \\
\hline 153 & 109 & C. DO CAMPINHO & 7,82 & $\mathrm{E}$ & 4406,72 & 1554,7 & 19,5 & 152,5 & 0,15 & 0,05 \\
\hline 154 & & $\mathrm{~S} / \mathrm{N}$ & & $E$ & 4406,72 & & & & & \\
\hline 155 & 77 & RIB. CANAS & 75,34 & D & 4482,06 & 1420,1 & 15,3 & 1149,9 & 1,15 & 0,38 \\
\hline 156 & & $\mathrm{~S} / \mathrm{N}$ & & $E$ & 4482,06 & & & & & \\
\hline
\end{tabular}




\begin{tabular}{|c|c|c|c|c|c|c|c|c|c|c|}
\hline Vi: & 1) & 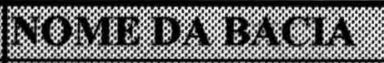 & Wrin & 18 & (1) & 2. & 16si & y. & (1) & (8. \\
\hline & 49 & & $(\mathrm{r}, 1 \mathrm{x})$ & & (ronining & 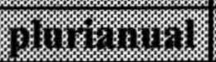 & (X) r. 1 ) & (1) & 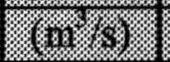 & 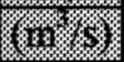 \\
\hline & & & & & & (7) & & & & \\
\hline 157 & 79 & \begin{tabular}{|l} 
RIB. DAS \\
CANINHAS \\
\end{tabular} & 30,96 & D & 4513,02 & 1407,3 & 14,9 & 460,1 & 0,46 & 0,15 \\
\hline 158 & 111 & C. BELA VISTA & 3,95 & E & 4516,97 & 1512,1 & 18,2 & 71,7 & 0,07 & 0,02 \\
\hline 159 & 113 & C. AREADO & 5,35 & $\mathrm{E}$ & 4522,32 & 1531,4 & 18,8 & 100,4 & 0,10 & 0,03 \\
\hline 160 & & $\mathrm{~S} / \mathrm{N}$ & & D & 4522,32 & & & & & \\
\hline 161 & 114 & C. DA AGUADA & 7,41 & $E$ & 4529,73 & 1496,1 & 17,7 & 130,8 & 0,13 & 0,04 \\
\hline 162 & 81 & RIB. DAS PITAS & 36,42 & D & 4566,15 & 1407,7 & 14,9 & 541,7 & 0,54 & 0,18 \\
\hline 163 & 83 & RIB. DA MINHOCA & 4,82 & D & 4570,97 & 1403,9 & 14,8 & 71,1 & 0,07 & 0,02 \\
\hline 164 & & $\mathrm{~S} / \mathrm{N}$ & & D & 4570,97 & & & & & \\
\hline 165 & 84 & RIB DA BOCAINA & 251,36 & D & 4822,33 & 1467 & 16,7 & 4207,9 & 4,21 & 1,40 \\
\hline 166 & & $\mathrm{~S} / \mathrm{N}$ & & D & 4822,33 & & & & & \\
\hline 167 & 86 & RIB. DAS PEDRAS & 14,29 & D & 4836,62 & 1407,3 & 14,9 & 212,3 & 0,21 & 0,07 \\
\hline 168 & & $\mathrm{~S} / \mathrm{N}$ & & $E$ & 4836,62 & & & & & \\
\hline 169 & 117 & R. PIQUETE & 348,56 & $\mathrm{E}$ & 5185,18 & 1769,4 & 26,3 & 9155,3 & 9,16 & 3,04 \\
\hline 170 & & $\mathrm{~S} / \mathrm{N}$ & & D & 5185,18 & & & & & \\
\hline 171 & 89 & $\begin{array}{l}\text { C. FAZ. VISTA } \\
\text { VERDE }\end{array}$ & 1,80 & D & 5186,98 & 1508,2 & 18,0 & 32,5 & 0,03 & 0,01 \\
\hline 172 & & $\mathrm{~S} / \mathrm{N}$ & & D & 5186,98 & & & & & \\
\hline 173 & 91 & $\begin{array}{l}\text { C. SANTA } \\
\text { TEREZINHA }\end{array}$ & 10,85 & D & 5197,83 & 1469 & 16,8 & 182,3 & 0,18 & 0,06 \\
\hline 174 & & $\mathrm{~S} / \mathrm{N}$ & & D & 5197,83 & & & & & \\
\hline 175 & & $\mathrm{~S} / \mathrm{N}$ & & $\mathrm{E}$ & 5197,83 & & & & & \\
\hline 176 & 94 & C. SÃO DOMINGOS & 3,40 & D & 5201,23 & 1481,6 & 17,2 & 58,5 & 0,06 & 0,02 \\
\hline 177 & 119 & C. DO PONTILHÃO & 13,40 & $\mathrm{E}$ & 5214,63 & 1577,5 & 20,2 & 271,0 & 0,27 & 0,09 \\
\hline 178 & & $\mathrm{~S} / \mathrm{N}$ & & D & 5214,63 & & & & & \\
\hline 179 & 120 & RIB. DOS LOPES & 60,22 & $\mathrm{E}$ & 5274,85 & 1651,6 & 22,6 & 1358,3 & 1,36 & 0,45 \\
\hline
\end{tabular}




\begin{tabular}{|c|c|c|c|c|c|c|c|c|c|c|}
\hline U1: & ro & 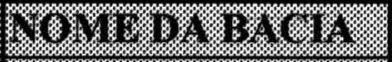 & r & 1818 (6) & (6. & U. $14(6)$ & $483^{3}$ & 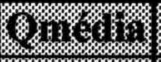 & (6) & 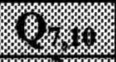 \\
\hline & (5) & & ( & & 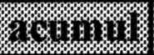 & 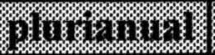 & (6) & (1: ( & 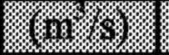 & $(19: 8)$ \\
\hline & & & & & & (1) (1818) & & & & \\
\hline & & OU ÁGUA LIMPA & & & & & & & & \\
\hline 180 & 97 & $\begin{array}{l}\text { C. DAS } \\
\text { PITANGUEIRASITG } \\
\text { AÇABA }\end{array}$ & 226,72 & $\mathrm{D}$ & 5501,57 & 1419,1 & 15,2 & 3453,3 & 3,45 & 1,15 \\
\hline 181 & & $\mathrm{~S} / \mathrm{N}$ & & $\mathrm{E}$ & 5501,57 & & & & & \\
\hline 182 & 121 & C. LINDEIRO & 1,30 & $\mathrm{E}$ & 5502,87 & 1550 & 19,4 & 25,2 & 0,03 & 0,01 \\
\hline 183 & 100 & C. MUNICIPAL & 0,75 & $\mathrm{D}$ & 5503,62 & 1550 & 19,4 & 14,5 & 0,01 & 0,00 \\
\hline 184 & & $\mathrm{~S} / \mathrm{N}$ & & $\mathrm{E}$ & 5503,62 & & & & & \\
\hline 185 & 101 & \begin{tabular}{|l|} 
C. DO \\
SERTÃO/CAMPO \\
\end{tabular} & 5,00 & $\mathrm{D}$ & 5508,62 & 1472,5 & 16,9 & 84,6 & 0,08 & 0,03 \\
\hline 186 & 122 & RIB. JACU & 83,87 & $\mathrm{E}$ & 5592,49 & 1672,5 & 23,2 & 1946,9 & 1,95 & 0,65 \\
\hline 187 & 123 & C. JACUZINHO & 13,52 & $\mathrm{E}$ & 5606,01 & 1550 & 19,4 & 261,7 & 0,26 & 0,09 \\
\hline 188 & & $\mathrm{~S} / \mathrm{N}$ & & $E$ & 5606,01 & & & & & \\
\hline 189 & 124 & C. DAS VELHAS & 2,27 & $\mathrm{E}$ & 5608,28 & 1495,7 & 17,6 & 40,1 & 0,04 & 0,01 \\
\hline 190 & & $\mathrm{~S} / \mathrm{N}$ & & $\mathrm{D}$ & 5608,28 & & & & & \\
\hline 191 & 103 & C. DA QUEIMADA & 6,15 & $\mathrm{D}$ & 5614,43 & 1450 & 16,2 & 99,7 & 0,10 & 0,03 \\
\hline 192 & & $\mathrm{~S} / \mathrm{N}$ & & $\mathrm{D}$ & 5614,43 & & & & & \\
\hline 193 & 104 & $\begin{array}{l}\text { C. DOS } \\
\text { GREGOS/CANEQUI } \\
\text { NHA }\end{array}$ & 7,10 & $\mathrm{D}$ & 5621,53 & 1450 & 16,2 & 115,1 & 0,12 & 0,04 \\
\hline 194 & 106 & C. DOS CORREIAS & 0,87 & $\mathrm{D}$ & 5622,40 & 1450 & 16,2 & 14,1 & 0,01 & 0,00 \\
\hline 195 & & $\mathrm{~S} / \mathrm{N}$ & & $\mathrm{D}$ & 5622,40 & & & & & \\
\hline 196 & 108 & $\begin{array}{l}\text { C. DA DIVIDSA - } \\
\text { MURANO }\end{array}$ & 1,95 & $\mathrm{D}$ & 5624,35 & 1450 & 16,2 & 31,6 & 0,03 & 0,01 \\
\hline 197 & & $\mathrm{~S} / \mathrm{N}$ & & $\mathrm{D}$ & 5624,35 & & & & & \\
\hline 198 & 110 & C. DO MORRO & 5,45 & $\mathrm{D}$ & 5629,80 & 1450 & 16,2 & 88,3 & 0,09 & 0,03 \\
\hline
\end{tabular}




\begin{tabular}{|c|c|c|c|c|c|c|c|c|c|c|}
\hline 16\% & (1) & 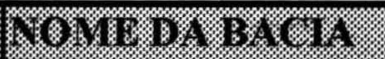 & 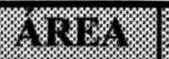 & 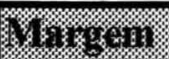 & (1) & 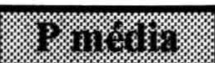 & Cesp & \% & 6. & 15, \\
\hline & (4:-1) & & $(4,1)$ & & 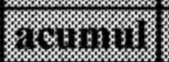 & 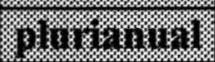 & (6) ( (3r) & 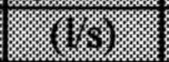 & 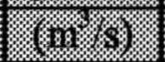 & $(17 \%)$ \\
\hline & & & & & & (1) & & & & \\
\hline & & GRANDE & & & & & & & & \\
\hline 199 & & $\mathrm{~S} / \mathrm{N}$ & & $\mathrm{E}$ & 5629,80 & & & & & \\
\hline 200 & 128 & RIB. CLARO & 51,42 & $\mathrm{E}$ & 5681,22 & 1592,7 & 20,7 & 1064,4 & 1,06 & 0,35 \\
\hline 201 & 112 & C. SANTANA & 5,30 & $\mathrm{D}$ & 5686,52 & 1447 & 16,1 & 85,4 & 0,09 & 0,03 \\
\hline 202 & & $\mathrm{~S} / \mathrm{N}$ & & $\mathrm{D}$ & 5686,52 & & & & & \\
\hline 203 & 115 & C. PIRUTINGA & 3,77 & $\mathrm{D}$ & 5690,29 & 1446,9 & 16,1 & 60,7 & 0,06 & 0,02 \\
\hline 204 & 129 & C. DA BARRINHA & 3,77 & $\mathrm{E}$ & 5694,06 & 1485,1 & 17,3 & 65,3 & 0,07 & 0,02 \\
\hline 205 & & $\mathrm{~S} / \mathrm{N}$ & & $\mathrm{D}$ & 5694,06 & & & & & \\
\hline 206 & & $\mathrm{~S} / \mathrm{N}$ & & $\mathrm{E}$ & 5694,06 & & & & & \\
\hline 207 & 130 & RIB. DO ENTUPIDO & 27,60 & $\mathrm{E}$ & 5721,66 & 1569,9 & 20,0 & 551,5 & 0,55 & 0,18 \\
\hline 208 & 116 & C. DA BARRA & 14,77 & $\mathrm{D}$ & 5736,43 & 1427,1 & 15,5 & 228,7 & 0,23 & 0,08 \\
\hline & PARB & $02900 /$ Flv. 58235000 & & & & & & & & \\
\hline 209 & 131 & RIB. VERDE & 7,07 & $\mathrm{E}$ & 5743,50 & 1479 & 17,1 & 121,0 & 0,12 & 0,04 \\
\hline 210 & & $\mathrm{~S} / \mathrm{N}$ & & $\mathrm{E}$ & 5743,50 & & & & & \\
\hline 211 & 132 & C. DA CASCATA I & 6,75 & $\mathrm{E}$ & 5750,25 & 1493,9 & 17,6 & 118,7 & 0,12 & 0,04 \\
\hline 212 & & $\mathrm{~S} / \mathrm{N}$ & & $\mathrm{E}$ & 5750,25 & & & & & \\
\hline 213 & 133 & C. DA CASCATA II & 2,02 & $\mathrm{E}$ & 5752,27 & 1450 & 16,2 & 32,7 & 0,03 & 0,01 \\
\hline 214 & & $\mathrm{~S} / \mathrm{N}$ & & $\mathrm{D}$ & 5752,27 & & & & & \\
\hline 215 & 134 & RIB. DAS CRUZES & 61,20 & $\mathrm{E}$ & 5813,47 & 1578,3 & 20,2 & 1239,1 & 1,24 & 0,41 \\
\hline 216 & 118 & C. DA GRAMA & 23,47 & $\mathrm{D}$ & 5836,94 & 1408,5 & 14,9 & 349,7 & 0,35 & 0,12 \\
\hline 217 & 135 & $\begin{array}{l}\text { C. DA PONTE } \\
\text { QUEBRADA }\end{array}$ & 1,25 & $\mathrm{E}$ & 5838,19 & 1450 & 16,2 & 20,3 & 0,02 & 0,01 \\
\hline 218 & & $\mathrm{~S} / \mathrm{N}$ & & $\mathrm{E}$ & 5838,19 & & & & & \\
\hline 219 & 136 & C. DAS MARRECAS & 4,00 & $\mathrm{E}$ & 5842,19 & 1450 & 16,2 & 64,8 & 0,06 & 0,02 \\
\hline 220 & & $\mathrm{~S} / \mathrm{N}$ & & $\mathrm{E}$ & 5842,19 & & & & & \\
\hline 221 & 137 & RIB. DO SALTO & 23,00 & $\mathrm{E}$ & 5865,19 & 1616,5 & 21,4 & 493,3 & 0,49 & 0,16 \\
\hline
\end{tabular}




\begin{tabular}{|c|c|c|c|c|c|c|c|c|c|c|}
\hline U1: & r. & 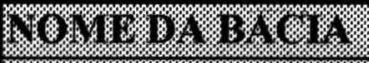 & 4 & 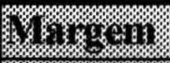 & 4.8.8. & \% 14.6. & (8)sig) & Y136) \& & \% & 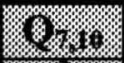 \\
\hline & 4.111 & & (8) & & reqminu & $131.5 \% 1101$ & (1) (3.1) & (1) & $(10.6)$ & $(17 \%$ \\
\hline & & & & & & $(18.18)$ & & & & \\
\hline 222 & & $\mathrm{~S} / \mathrm{N}$ & & D & 5865,19 & & & & & \\
\hline 223 & 125 & C. SANTA CLARA & 11,87 & $\mathrm{D}$ & 5877,06 & 1354,9 & 13,2 & 156,8 & 0,16 & 0,05 \\
\hline 224 & 126 & RIB. VERMELHO & 94,37 & D & 5971,43 & 1418,8 & 15,2 & 1436,5 & 1,44 & 0,48 \\
\hline 225 & 127 & $\begin{array}{l}\text { RIB. SANTANA/V. } \\
\text { GRANDE }\end{array}$ & 82,42 & D & 6053,85 & 1524,1 & 18,5 & 1528,0 & 1,53 & 0,51 \\
\hline
\end{tabular}

Fonte: DAEE (1988 e 1994) 
ANEXO 5 - Carga de Poluentes no trecho paulista do rio Paraíba do Sul

\begin{tabular}{|c|c|c|c|c|c|c|c|c|c|}
\hline 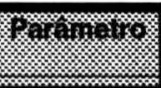 & mongen & \multicolumn{2}{|c|}{ Un, } & mark & mom & $\log (3)$ & 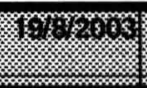 & 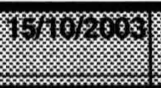 & 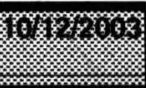 \\
\hline \multirow[t]{10}{*}{ Alumínio } & tAldia & JAGI & 02900 & 5,687 & 0,703 & 0,135 & 0,590 & 2,838 & 0,614 \\
\hline & & \multirow{9}{*}{ PARB } & 02100 & 4,291 & 3,383 & 1.797 & 5,467 & 0,763 & 1,128 \\
\hline & & & 02200 & 8,550 & 3,716 & 6,292 & 3,444 & 1,703 & 2,839 \\
\hline & & & 02300 & 14,196 & 4,150 & 13,020 & 3,565 & 5,831 & 3,068 \\
\hline & & & 02310 & 7,107 & 2,494 & 10,462 & 3,838 & 3.893 & 3.831 \\
\hline & & & 02400 & 12,797 & 4,195 & 10,762 & 5,685 & 7,944 & 4,750 \\
\hline & & & 02490 & 15,334 & 4,783 & 8,161 & 11,790 & 12,218 & 8,016 \\
\hline & & & 02600 & 21,194 & 8,145 & 23,399 & 7,551 & 67,115 & 11,175 \\
\hline & & & 02700 & 16,630 & 7,710 & 13,770 & 9,092 & 59,246 & 11,595 \\
\hline & & & 02900 & 14,836 & 34,504 & 19,902 & 8,809 & 69,971 & 10,739 \\
\hline \multicolumn{4}{|c|}{ Carga adicionada entre PARB 02310 e 02400} & 0,004 & 0,998 & 0,165 & 1,257 & 1,214 & 0,306 \\
\hline \multirow[t]{10}{*}{ DQO } & tDQO/dia & JAGI & 02900 & 10,475 & 5,986 & 5,986 & 9,442 & 6,677 & 10,475 \\
\hline & & \multirow[t]{9}{*}{ PARB } & 02100 & 14,304 & 14,550 & 44,928 & 24,296 & 15,267 & 27.219 \\
\hline & & & 02200 & 28,500 & 14,022 & 40,593 & 72,860 & 26,486 & 49,076 \\
\hline & & & 02300 & 29,226 & 14,436 & 41,008 & 26,909 & 27,212 & 64,964 \\
\hline & & & 02310 & 29,262 & 14,457 & 41,028 & 26,930 & 27,248 & 39,757 \\
\hline & & & 02400 & 47,146 & 24,677 & 51,248 & 40,605 & 72,823 & 111,045 \\
\hline & & & 02490 & 51,114 & 87,567 & 147,166 & 42,872 & 158,115 & 121,247 \\
\hline & & & 02600 & 148,356 & 125,872 & 147,923 & 41,948 & 199,916 & 130,612 \\
\hline & & & 02700 & 39,128 & 26,358 & 138,964 & 38,689 & 242,369 & 141,712 \\
\hline & & & 02900 & 42,387 & 74,042 & 147,923 & 41,948 & 257,035 & 130,612 \\
\hline \multicolumn{4}{|c|}{ Carga adicionada entre PARB 02310 e 02400} & 7,409 & 4,234 & 4,234 & 4,234 & 38,898 & 60,812 \\
\hline Fósforo & tPtdia & JAGI & 02900 & 0,030 & 0,030 & 0,075 & 0,142 & 0,100 & 0,165 \\
\hline \multirow[t]{9}{*}{ Total } & & \multirow[t]{9}{*}{ PARB } & 02100 & 0,036 & 0,036 & 0,112 & 0,121 & 0,038 & 0,156 \\
\hline & & & 02200 & 0,366 & 0,105 & 0,304 & 0,265 & 0,114 & 0,280 \\
\hline & & & 02300 & 0,209 & 0,253 & 0,205 & 0,269 & 0,078 & 0,361 \\
\hline & & & 02310 & 0,167 & 0,217 & 0,410 & 0,269 & 0.078 & 0.289 \\
\hline & & & 02400 & 0,337 & 0,370 & 0,512 & 0,609 & 0,265 & 0,370 \\
\hline & & & 02490 & 0,438 & 0,606 & 0,401 & 0.536 & 0.575 & 0,876 \\
\hline & & & 02600 & 1,060 & 0,666 & 0,134 & 0,839 & 1.714 & 0,871 \\
\hline & & & 02700 & 0,685 & 0,461 & 0,379 & 0,097 & 0,269 & 0,644 \\
\hline & & & 02900 & 0,530 & 0,444 & 1,076 & 0,419 & 1,571 & 0,726 \\
\hline \multicolumn{4}{|c|}{ Carga adicionada entre PARB 02310 e 02400} & 0,140 & 0,123 & 0,027 & 0,198 & 0,087 & $-0,084$ \\
\hline \multirow[t]{10}{*}{ NKT } & INKT/dia & JAGI & 02900 & 0,314 & 0,374 & 0,569 & 0.448 & 3,338 & 0,524 \\
\hline & & \multirow[t]{9}{*}{ PARB } & 02100 & 1,109 & 0,691 & 2,808 & 0,850 & 1,679 & 0,467 \\
\hline & & & 02200 & 0,204 & 1,788 & 4,668 & 2,451 & 0,795 & 2,243 \\
\hline & & & 02300 & 0,793 & 1,191 & 3,178 & 2,220 & 1,710 & 2,274 \\
\hline & & & 02310 & 0,920 & 1,193 & 3,180 & 2,356 & 1,635 & 2,096 \\
\hline & & & 02400 & 1,145 & 2,838 & 5,637 & 5,177 & 2,913 & 3,393 \\
\hline & & & 02490 & 1,387 & 3,301 & 5,084 & 2,251 & 2,515 & 3,301 \\
\hline & & & 02600 & 3,179 & 5,775 & 7,531 & 4,090 & 7,854 & 2,902 \\
\hline & & & 02700 & 3,228 & 2,636 & 3,916 & 2,805 & 6,867 & 2,383 \\
\hline & & & 02900 & 1,272 & 2,147 & 4,841 & 3,041 & 6,854 & 2,540 \\
\hline \multicolumn{4}{|c|}{ Carga adicionada entre PARB 02310 e 02400} & $-0,09$ & 1,27 & 1,89 & 2,37 & $-2,06$ & 0,77 \\
\hline Resíduo & Res.Filtr/dia & JAGI & 02900 & 70,33 & 148,15 & 121,21 & 61,37 & 70,11 & 44,89 \\
\hline Filtrável & & PARB & 02100 & 110,86 & 291,00 & 539,14 & 133,63 & 95,42 & 139,98 \\
\hline
\end{tabular}




\begin{tabular}{|c|c|c|c|c|c|c|c|c|c|}
\hline$x^{2}$ & $y^{3}$ & \multicolumn{2}{|c|}{ 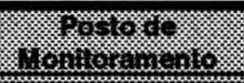 } & 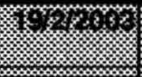 & 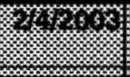 & 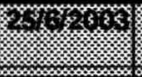 & $x^{2}$ & $x^{2}$ & 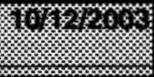 \\
\hline & & & 02200 & 423,43 & 368,07 & 893,05 & 370,92 & 276,21 & 147,23 \\
\hline & & & 02300 & 501,02 & 519,71 & 922,67 & 518,00 & 318,77 & 281,51 \\
\hline & & & 02310 & 434,75 & 444,56 & 851,34 & 484,74 & 365,90 & 307,22 \\
\hline & & & 02400 & 700,46 & 801,99 & 1076,20 & 700,44 & 436,94 & 1048,76 \\
\hline & & & 02490 & 664,48 & 740,95 & 1137,19 & 857,45 & 574,96 & 599,50 \\
\hline & & & 02600 & 932,52 & 918,12 & 1143,04 & 828,47 & 1370,85 & 616,78 \\
\hline & & & 02700 & 987,99 & 830,27 & 1111,69 & 706,07 & 1157,99 & 521,76 \\
\hline & & & 02900 & 1144,46 & 969,95 & 1223,73 & 838,96 & 1213,78 & 1153,74 \\
\hline \multicolumn{4}{|c|}{ Carga adicionada entre PARB 02310 e 02400} & 195,37 & 209,28 & 103,65 & 154,33 & 0,92 & 696,65 \\
\hline Coliforme & $\begin{array}{c}\text { (NMP/100 } \\
\mathrm{ml}) \mathrm{l}\end{array}$ & JAGI & 02900 & $2,3 E+05$ & & & & $2,1 E+05$ & $4,0 E+04$ \\
\hline \multirow[t]{9}{*}{ Fecal } & $\left(\mathrm{m}^{3} / \mathrm{s}\right)$ & \multirow[t]{9}{*}{ PARB } & 02100 & $9,5 E+03$ & $9,3 E+02$ & $1,7 E+05$ & $3,5 E+03$ & $5,7 E+03$ & $1,0 \mathrm{E}+04$ \\
\hline & $100 \mathrm{~mL}$ & & 02200 & $2,4 E+05$ & $1,2 E+05$ & $5,9 E+05$ & $1,3 E+05$ & $2,1 E+05$ & $9,3 E+04$ \\
\hline & & & 02300 & $1,1 \mathrm{E}+05$ & $9,6 \mathrm{E}+05$ & $1,3 E+06$ & $2,3 \mathrm{E}+05$ & $9,9 \mathrm{E}+04$ & $5,4 \mathrm{E}+05$ \\
\hline & & & 02310 & $1,5 \mathrm{E}+06$ & $5,4 \mathrm{E}+05$ & $9,5 \mathrm{E}+05$ & $1,0 E+06$ & $7,7 \mathrm{E}+05$ & $2,0 E+05$ \\
\hline & & & 02400 & $6,2 E+05$ & $5,7 \mathrm{E}+05$ & $1,2 E+06$ & $2,0 E+05$ & $3,8 \mathrm{E}+05$ & $9,3 E+04$ \\
\hline & & & 02490 & $1,1 \mathrm{E}+06$ & $1,8 \mathrm{E}+06$ & $1,2 E+06$ & $1,6 \mathrm{E}+05$ & $1,4 \mathrm{E}+05$ & $1,0 E+06$ \\
\hline & & & 02600 & $6,1 \mathrm{E}+06$ & $7,7 \mathrm{E}+07$ & $2,0 \mathrm{E}+06$ & $3,6 \mathrm{E}+05$ & $3,6 E+06$ & $1,1 \mathrm{E}+07$ \\
\hline & & & 02700 & $3,4 \mathrm{E}+05$ & $2,3 E+07$ & $1,2 E+06$ & $1,5 \mathrm{E}+05$ & $5,1 E+06$ & $9,7 \mathrm{E}+05$ \\
\hline & & & 02900 & $6,1 E+05$ & $4,3 \mathrm{E}+06$ & $7,8 E+05$ & $6,1 E+05$ & $8,1 E+05$ & $4,1 E+05$ \\
\hline \multicolumn{4}{|c|}{ Carga adicionada entre PARB 02310 e 02400} & $-1,1 \mathrm{E}+06$ & $2,7 \mathrm{E}+04$ & $2,4 E+05$ & $-8,1 E+05$ & $-6,0 E+05$ & $-1,5 \mathrm{E}+05$ \\
\hline
\end{tabular}


Anexo 6 - Uso e ocupação/cobertura do solo por sub-bacias na região de estudo.

\begin{tabular}{|c|c|c|c|c|c|c|c|c|c|c|}
\hline & 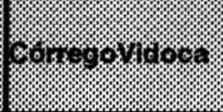 & \% & \% & 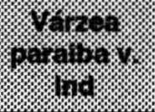 & \%.. & $\sqrt{14}$ & 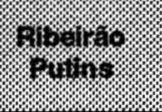 & 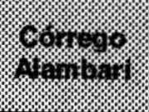 & \% & 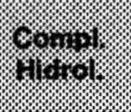 \\
\hline 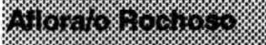 & 0,000 & 0,000 & 0,000 & 0,000 & 0,000 & 0,000 & 0,000 & 0,000 & 0,000 & 0,000 \\
\hline c. & 16,906 & 6,408 & 8,698 & 2,275 & 1,296 & 1,670 & 37,051 & 22,723 & 4,637 & 3,125 \\
\hline 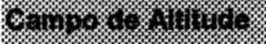 & 0,000 & 0,000 & 0,000 & 0,000 & 0,000 & 0,000 & 0,000 & 0,000 & 0,000 & 0,000 \\
\hline tis & 2,045 & 0,000 & 0,000 & 0,000 & 0,000 & 0,000 & 0,821 & 2,909 & 0,014 & 0,000 \\
\hline \% & 0,086 & 0,000 & 0,000 & 0,000 & 0,000 & 0,000 & 0,000 & 0,000 & 0,000 & 0,000 \\
\hline 4 & 0,994 & 0,000 & 0,000 & 0,418 & 0,158 & 0,130 & 2,434 & 1,138 & 0,144 & 0,619 \\
\hline 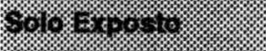 & 0,000 & 0,000 & 0,000 & 0,000 & 0,000 & 0,000 & 0,000 & 0,000 & 0,000 & 0,000 \\
\hline (3) & 0,000 & 0,000 & 0,000 & 0,000 & 0,000 & 0,000 & 0,000 & 0,000 & 0,158 & 0,058 \\
\hline 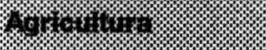 & 0,000 & 0,000 & 0,000 & 0,245 & 0,014 & 0,086 & 0,043 & 0,000 & 0,518 & 0,000 \\
\hline $\sin 4=1$ & 0,000 & 0,000 & 0,000 & 0,000 & 0,000 & 0,000 & 0,000 & 0,000 & 0,389 & 5,227 \\
\hline 4) : & 0,000 & 0,000 & 0,000 & 0,000 & 0,000 & 0,000 & 0,000 & 0,000 & 0,000 & 0,274 \\
\hline bis & 30,614 & 5,112 & 7,574 & 0,202 & 1,325 & 0,000 & 8,669 & 8,107 & 3,154 & 0,000 \\
\hline 18. & 50,645 & 11,520 & 16,272 & 3,139 & 2,794 & 1,886 & 49,018 & 34,877 & 9,014 & 9,302 \\
\hline
\end{tabular}




\begin{tabular}{|c|c|c|c|c|c|c|c|c|c|c|}
\hline & $\frac{6}{6} x^{2}$ & 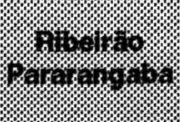 & 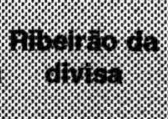 & / & 4 & s. & y. & 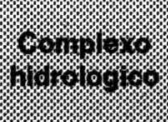 & 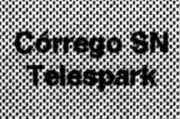 & /4. \\
\hline 4 & 0,000 & 0,000 & 0,000 & 0,000 & 0,000 & 0,000 & 0,029 & 0,000 & 0,000 & 0,000 \\
\hline 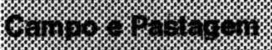 & 1,483 & 51,106 & 58,018 & 26,165 & 4,723 & 5,414 & 232,790 & 1,526 & 0,734 & 4,752 \\
\hline 6 & 0,000 & 0,000 & 0,000 & 0,000 & 0,000 & 0,000 & 0,216 & 0,000 & 0,000 & 0,000 \\
\hline y. & 0,000 & 1,094 & 1,008 & 0,000 & 0,000 & 0,000 & 2,261 & 0,000 & 0,000 & 0,000 \\
\hline 1) & 0,000 & 0,000 & 1,483 & 1,526 & 1,757 & 1,210 & 112,018 & 0,000 & 0,000 & 0,000 \\
\hline 4. & 0,014 & 4,478 & 5,314 & 4,450 & 2,938 & 0,763 & 81,734 & 0,187 & 0,000 & 0,763 \\
\hline $40 \%$ & 0,000 & 0,000 & 0,000 & 0,000 & 0,000 & 0,000 & 0,144 & 0,000 & 0,000 & 0,000 \\
\hline 40 & 0,130 & 0,130 & 0,000 & 0,000 & 0,000 & 0,000 & 0,000 & 0,000 & 0,000 & 0,000 \\
\hline $6 \%$ & 0,000 & 0,101 & 0,000 & 0,000 & 0,000 & 0,000 & 0,000 & 0,000 & 0,000 & 0,000 \\
\hline 40 & 4,291 & 1,310 & 0,000 & 0,000 & 0,778 & 1,973 & 0,000 & 0,000 & 0,000 & 0,605 \\
\hline 40 & 0,000 & 0,000 & 0,000 & 0,130 & 0,000 & 0,000 & 0,000 & 0,000 & 0,000 & 0,000 \\
\hline L & 0,173 & 14,746 & 2,981 & 0,000 & 0,000 & 0,000 & 1,469 & 0,000 & 1,253 & 0,000 \\
\hline 18<4, & 6,091 & 72,965 & 68,803 & 32,270 & 10,195 & 9,360 & 430,661 & 1,714 & 1,987 & 6,120 \\
\hline
\end{tabular}




\begin{tabular}{|c|c|c|c|c|c|c|c|c|c|}
\hline & 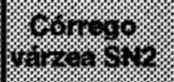 & 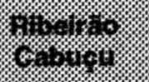 & 4 & 4 & 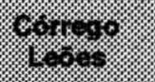 & 4 & (1) & $4 x^{2}$ & 8. \\
\hline 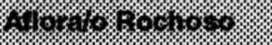 & 0,000 & 0,000 & 0,000 & 0,000 & 0,000 & 0,000 & 0,000 & 0,000 & 0,029 \\
\hline $625 \times 4$ - & 7,819 & 37,901 & 3,586 & 3,139 & 3,931 & 3,528 & 15,422 & 29,981 & 596,808 \\
\hline 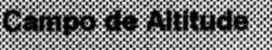 & 0,000 & 0,000 & 0,000 & 0,000 & 0,000 & 0,000 & 0,000 & 0,000 & 0,216 \\
\hline 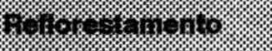 & 0,000 & 3,024 & 0,000 & 0,000 & 0,000 & 0,418 & 0,043 & 2,088 & 15,725 \\
\hline \% & 0,000 & 7,646 & 0,000 & 0,000 & 0,000 & 0,000 & 0,000 & 5,501 & 131,227 \\
\hline $4 \cos 2$. & 1,022 & 1,872 & 0,000 & 0,000 & 0,000 & 0,000 & 0,043 & 1,440 & 111,053 \\
\hline 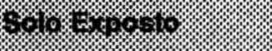 & 0,000 & 0,000 & 0,000 & 0,000 & 0,000 & 0,000 & 0,000 & 0,000 & 0,144 \\
\hline 4 & 0,000 & 0,000 & 0,000 & 0,000 & 0,000 & 0,000 & 0,115 & 0,000 & 0,590 \\
\hline 40 & 0,000 & 0,317 & 0,000 & 0,000 & 0,000 & 0,000 & 0,000 & 0,000 & 1,325 \\
\hline 4 & 0,000 & 2,146 & 0,000 & 0,000 & 0,000 & 0,187 & 0,000 & 0,000 & 16,906 \\
\hline$y_{1}$ & 0,000 & 1,368 & 0,000 & 0,000 & 0,000 & 0,475 & 0,000 & 0,000 & 2,246 \\
\hline 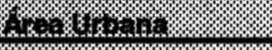 & 0,000 & 0,000 & 0,331 & 0,446 & 0,864 & 0,000 & 5,213 & 0,000 & 92,232 \\
\hline 18 & 8,842 & 54,274 & 3,917 & 3,586 & 4,795 & 4,608 & 20,837 & 39,010 & 968,501 \\
\hline
\end{tabular}

